\title{
Coal Mine Bumps as Related to Geologic Features in the Northern Part of the Sunnyside District, Carbon County, Utah
}

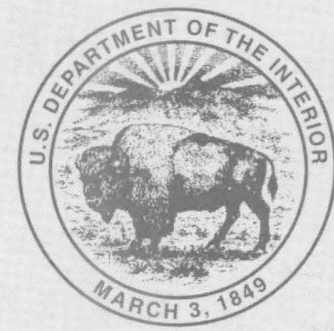



COAL MINE BUMPS

AS RELATED TO

GEOLOGIC FEATURES IN THE

NORTHERN PART OF THE SUNNYSIDE DISTRICT, CARBON COUNTY, UTAH 


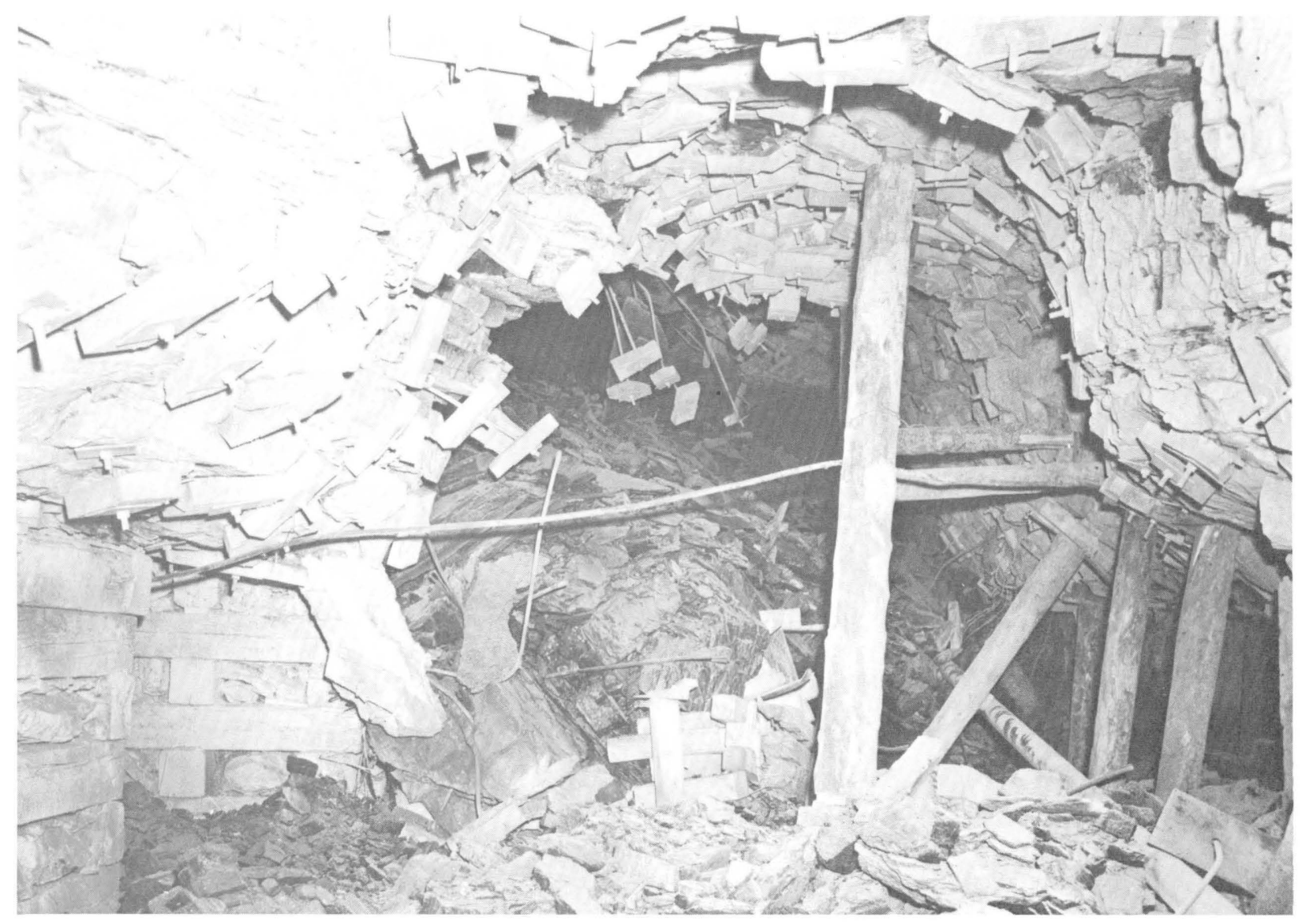

Frontispiece. View upslope (updip) of right-side manway, Sunnyside No. 1 Mine, Utah, showing mass of rock thrown from left rib by violent bump (rock burst) on December 4, 1957. Three men were killed near the cribbing and timber prop in lower central part of picture. Two men and a horse escaped because they had passed through a door in crosscut to left of picture; one other man escaped injury because he had not yet left the crosscut in lower right part of picture. Roof bolts are $2.5 \mathrm{~cm}(1 \mathrm{in}$.) in diameter. Photograph by J. C. Witt. 


\section{Coal Mine Bumps as Related to Geologic Features in the Northern Part of the Sunnyside District, Carbon County, Utah}

By FRANK W. OSTERWALD, C. RICHARD DUNRUD, and DONLEY S. COLLINS

U.S. GEOLOGICAL SURVEYPROFESSIONAL PAPER 1514

Description and interpretation of many geologic

factors that influence the occurrence and

magnitude of coal mine bumps in an

east-central Utah coal mining area

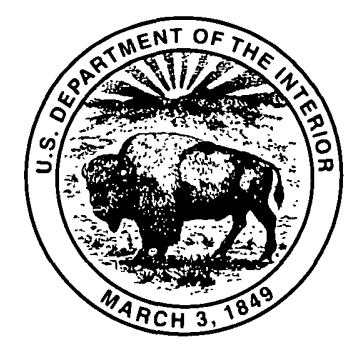

UNITED STATES GOVERNMENT PRINTING OFFICE, WASHINGTON:1993 


\title{
U.S. DEPARTMENT OF THE INTERIOR
}

BRUCE BABBITT, Secretary

\section{U.S. GEOLOGICAL SURVEY}

Robert M. Hirsch, Acting Director

\author{
For sale by \\ USGS Map Distribution \\ Box 25286, Building 810 \\ Denver Federal Center \\ Denver, CO 80225
}

Any use of trade, product, or firm names in this publication is for descriptive purposes only and does not imply endorsement by the U.S. Government

Library of Congress Cataloging in Publication Data

Osterwald, Frank W.

Coal mine bumps as related to geologic features in the northern part of the Sunnyside District, Carbon County, Utah / by Frank W. Osterwald, C. Richard Dunrud, and Donley S. Collins.

p. cm.-(U.S. Geological Survey professional paper ; 1514)

Includes bibliographical references. (p. )

Supt. of Docs. no.: I 19.16:1514

1. Rock burst-Utah-Carbon County. 2. Mining geology-Utah-Carbon County. 3. Coal mines and miningUtah-Carbon County-Accidents. I. Dunrud, C. Richard. II. Collins, Donley S. III Title. IV. Series.

TN317.0829 1993

$622^{\prime} .334 \mathrm{~s}-\mathrm{dc} 20$

90-3989 


\section{CONTENTS}

Glossary

Abstract

Introduction

Acknowledgments

Geologic features

Stress history of the coal

Bumps

Deformational features in mine openings

Pre-mine deformational features

Shatter zones

Cleavage

Pyrite veins

Smooth, curved fracture

Correlations between bumps and orientations of pre-mine fractures

Post-mine deformational features

Smooth planar fractures

Bedding-plane shears

Curved shear fractures

Creep

"Baskets full of rocks" (lateral shear zones in mine roofs)

Floor anticlines (heaves)

Other types of heaves

Roof synclines (horsebacks)

Buckled ribs
Influence of floor and roof rocks on deformation of Page Lithologic and structural characteristics ...................... 30

Stratigraphic characteristics .......................................... 32

Sedimentary structures $\ldots \ldots \ldots . . . . . .32$

Sedimentary structures with preferred orientations . 33

Crossbeds ............................................................ 33

Trace fossils .................................................... 33

Current ripple marks .......................................... 33

Paleostream channels ...................................... 33

Sedimentary structures with no preferred orientation ............................................... 33

Load casts ...................................................... 33

Intertongued contacts ........................................ 34

Stress distribution around mine openings .......................... 34

Influence of faults ............................................................... 40

Subsidence of the land surface ............................................... 41

Strength, stress-strain characteristics, and chemical

variations in coal from the Sunnyside coal bed ........... 27

Terminology ....................................................... 47

Laboratory results ....................................................... 48

Confined and unconfined compressive tests .................... $\quad 49$

Creep tests ................................................................ 58

Changes in chemical composition related to stresses in coal .. $\quad 68$

Conclusions .................................................................. 71

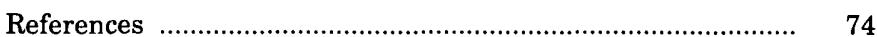

\section{ILLUSTRATIONS}

[Plates are in pocket]

Plate 1. Underground engineering geologic map of part of Sunnyside No. 1 Mine.

2. Fence diagram through main slopes and main motor roads, Sunnyside No. 1 Mine.

3. Underground engineering geologic map of south part of Sunnyside No. 2 Mine and north part of Columbia Mine.

4. Vertical panel diagram showing lithologic variations in rocks above Sunnyside coal bed, Sunnyside No. 2 Mine and Columbia Mine.

5. Map of part of north side of Sunnyside No. 3 Mine showing coal pillars left in place to support Grassy Trail Creek.

Frontispiece Photograph of view upslope of right-side manway, Sunnyside No. 1 Mine.

FIGURE 1. Index map of Utah showing the mines and major features of Sunnyside coal mining district.

2. Map showing boundaries of coal mines and major geologic features in the Sunnyside coal mining district 
Figure $\quad 3-6$. Photographs showing:

3. View down right-side manway, Sunnyside No. 1 Mine, Utah, near lower end of rock mass that resulted from bump (burst)

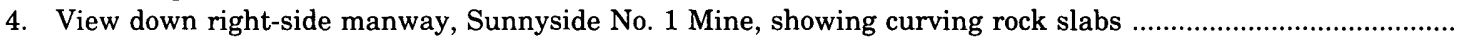

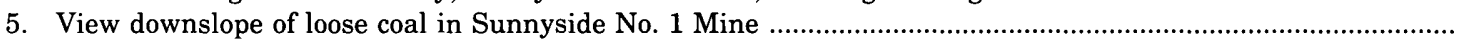

6. View downslope of left rib, left-side manway, Sunnyside No. 1 Mine

7. Geologic map of 11 th left track entry section, Sunnyside No. 1 Mine

8-11. Photographs showing:

8. Coal creeping into right-side manway at 1st right entry, Sunnyside No. 1 Mine

9. Nearly vertical shatter zone in coal, Sunnyside No. 1 Mine

10. Closely spaced spotted cleavage planes in main manway, Sunnyside No. 1 Mine

11. Spotted cleavage surfaces in upper part of coal bed, Sunnyside No. 1 Mine ..

12. Underground engineering geologic map, left-side bleeder slopes, Sunnyside No. 3 Mine

13. Photograph showing veins filled with claystone and pyrite, near top of Sunnyside coal bed

14. Photograph showing curved fractures, Sunnyside No. 1 Mine

15. Hypothetical stress trajectories around underground opening

16. Photograph showing roof syncline, Sunnyside No. 1 Mine

17. Photograph showing floor anticline, Sunnyside No. 1 Mine

18. Underground geologic map, right-side bleeder slopes, Sunnyside No. 1 Mine

19-22. Photographs showing:

19. Bedding-plane shear between coals of different properties, Sunnyside No. 1 Mine

20. Rib coal at pillar corner creeping into manway, Sunnyside No. 1 Mine .......

21. Curved shear fractures in upper part of rib, Columbia Mine

22. Curved shear fracture passing through coal pillar, Sunnyside No. 1 Mine

23. Curved shear fractures, Sunnyside No. 1 Mine, shown by vertical cross section and diagrammatic sketch showing

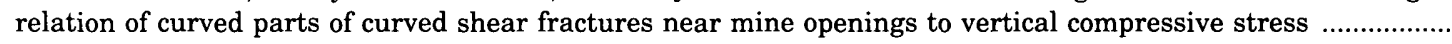

24. Underground geologic map of right-hand airway at Sunnyside fault zone, Sunnyside No. 1 Mine

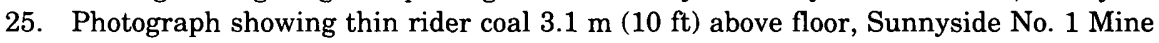

26. Diagrammatic vertical cross section showing failure in mine roof along shear zone ("basket full of rocks")

27. Diagrams of deformation and stress distribution around openings in Sunnyside No. 1 Mine

28. Photograph and cross section showing failures of floor in Sunnyside No. 2 Mine

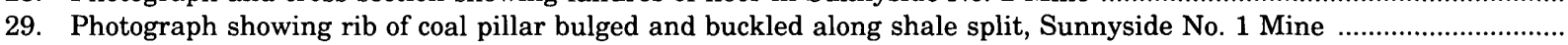

30. Photograph showing downdip side of dome-shaped cavity in roof, Columbia Mine

31. Photograph showing large horizontal burrows in roof, Sunnyside No. 1 Mine

32. Diagrammatic sketch of intertongued coal and roof rocks, Sunnyside No. 1 Mine

33-35. Photographs showing:

33. Crossbars in Sunnyside No. 2 Mine

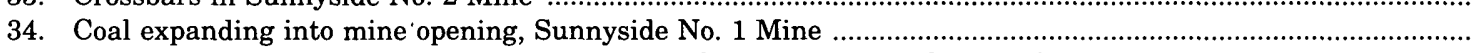

35. Inversely curved shear fractures in siltstone, right-side manway, Sunnyside No. 1 Mine

36. Diagrammatic section showing shear failures in mine opening

37. Map showing bumping and nonbumping areas, Sunnyside No. 2 Mine

38. Cross section of distances measured between roof bolts, Sunnyside No. 1 Mine

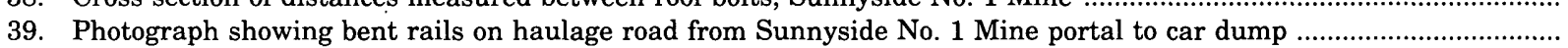

40. Graph showing changes between marked points along rail haulage road, Sunnyside No. 1 Mine

41-45. Photographs showing:

41. Subsidence cracks in Lila Canyon above the Book Cliffs Mine

42. Oblique aerial photograph showing graben in Colton Formation on east side and top of West Ridge, above Sunnyside No. 1 Mine

43. Subsidence cracks in surficial materials above the Sunnyside No. 1 Mine in 1959

44. Subsidence cracks in colluvium overlying Bluecastle Sandstone Member of Price River Formation along west side of Whitmore Canyon, Sunnyside No. 1 Mine

45. View north of zigzag fractures following bedrock joints on top of stripped surface of Castlegate Sandstone ..

46. Diagrammatic sketches showing effects of subsidence into mine openings

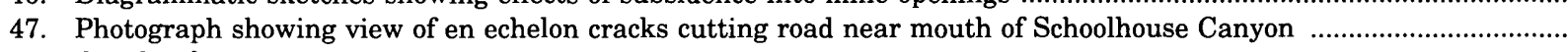
48-63. Graphs showing:

48. Stress-strain curves for unconfined compressive strength test of coal cores from Sunnyside No. 1 Mine ........

49. Stress-strain curves for triaxial compressive tests of coal cores from Sunnyside No. 1 Mine using a confining stress of $1,380 \mathrm{kPa}$

50. Stress-strain curve for triaxial compressive test of coal core from Sunnyside No. 1 Mine using a confining stress of $6,895 \mathrm{kPa}$

51. Stress-strain curves for triaxial compressive test of coal core from Sunnyside No. 1 Mine using a confining stress of $34,480 \mathrm{kPa}$

52. Triaxial compressive test results of coal cores from Sunnyside No. 1 Mine showing axial strain on horizontal axis plotted against differential stress 
FiguRe 48-63. Graphs showing-Continued:

53. Stress-strain curve for triaxial compressive test of coal core from Sunnyside No. 1 Mine subjected to repeated cycles of loading at a confining stress of $6,895 \mathrm{kPa}$

54. Mohr diagrams for cores from Sunnyside coal bed

55. Deflection of a coal bar from Sunnyside No. 1 Mine, weighted with $95 \mathrm{~g}$, versus linear time scale

56. Deflection of coal bars weighted with $95 \mathrm{~g}$ plotted against time, Sunnyside No. 1 Mine

57. Deflection of coal bars weighted with $105 \mathrm{~g}$ and $115 \mathrm{~g}$, plotted against logarithm of time, Sunnyside No. 1 Mine

58. Deflection of coal bars weighted with $135 \mathrm{~g}, 145 \mathrm{~g}$, and $155 \mathrm{~g}$, plotted against logarithm of time, Sunnyside No. 1 Mine

59. Deflection of coal bars weighted with $165 \mathrm{~g}$ and $175 \mathrm{~g}$, plotted against logarithm of time, Sunnyside No. 1 Mine

60. Deflection of coal bars weighted with $85 \mathrm{~g}$ plotted against logarithm of time, Sunnyside No. 1 Mine

61. Results of triaxial compressive testing of coal cores from Sunnyside No. 1 and No. 3 Mines showing small variations in strengths of cores

62. Infrared spectra of vitrains from coal cores, Sunnyside No. 3 Mine

63. Ternary diagrams showing axial (longitudinal) compressive stress, confining stress, and infrared transmittance corresponding to content of organic-chemical compounds in vitrain from coal cores, Sunnyside No. 3 Mine

64. Ternary diagram showing axial (longitudinal) compressive stress, confining stress, and infrared transmittance corresponding to the kaolinite content in coal cores vitrain from Sunnyside No. 3 Mine

\section{TABLES}

TABLE 1. Triaxial compressive test results, NX drill cores of coal, Sunnyside No. 1 Mine

2. Unconfined compressive test results on 54-mm NX drill cores of coal from Sunnyside No. 3 Mine

3. Unconfined compressive tests on coal cubes from Sunnyside No. 3 Mine

4. Summary of triaxial compressive test results on NX drill cores from a block of coal, Sunnyside No. 3 Mine

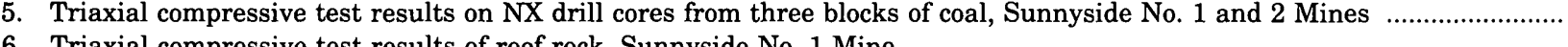

7. Deflections of coal bars and computed moduli of elasticity 


\section{GLOSSARY OF GEOLOGIC AND MINING TERMS}

abutment zone a. In underground mining, the zone to which an abutment load (above an excavation which has been transferred to the adjoining walls) is applied. (See also abutment, Thrush and others, 1968.)

air course "a. Ventilating passage underground. b. A passage through which air is circulated, $* * *$ particularly a long passageway driven parallel to the workings to carry the air current." (Thrush and others, 1968.)

airway "Any underground gallery or passage through which a portion of the ventilation passes; that is, the air is carried. Sometimes referred to as an air course. Also called wind road." (Thrush and others, 1968.)

angle of draw Angle that the limit line makes with a vertical reference (also known as limit angle).

back filling "The filling-in again of a place from which the rock or ore has been removed." (Thrush and others, 1968.)

barrier pillar "a. A solid block or rib of coal, etc., left unworked between two collieries or mines for security against accidents arising from an influx of water. b. Any large pillar entirely or relatively unbroken by roadways or airways that is left around a property to protect it against water and squeezes from adjacent property, or to protect the latter property in a similar manner. c. Incorrectly used for a similar pillar left to protect a roadway or airway, or group of roadways or airways, or a panel of rooms from a squeeze." (Thrush and others, 1968.)

"baskets full of rocks" Shear zones that form locally in roofs of mine openings, commonly near the sites of violent bumps. Applied specifically to failures of brittle roof rocks, partially supported by steel mats held up by roof bolts.

bedding-plane shears Bedding planes between coal beds and overlying rocks that act as planes of shear during deformation.

begin to work A phrase used by miners of the Sunnyside district that refers to active rock noises and small movements.

bench "a. One of two or more divisions of a coal bed, separated by slate, etc., or simply separated by the process of cutting the coal, one bench or layer being cut before the adjacent one $* * *$. f. A level layer worked separately in a mine ***." (Thrush and others, 1968.)

bleeder slopes Slopes driven near the boundaries of individual mines to provide passages for return ventilation and escape ways for miners. Equivalent to "bleeder entries."

block sample Large rock or coal sample that exceeds $0.7-1.4 \mathrm{~m}(2-4 \mathrm{ft})$ in thickness, following the definition of McKee and Weir (1953, p. 383).

blower See blowouts.

blowouts A phenomenon, "*** triggered by the dynamic failure of the outburst coal during the change from confined to unconfined stress conditions in the face of an advancing working excavation, and extended by the subsequent desorption of gas contained in the coal structure." (Farmer and Pooley, 1967, p. 189). See outburst(s).

bounces A term used by local miners for rock bursts and bumps in coal. "A sudden spalling off of the sides of ribs and pillars due to excessive pressure; a bump ***." (Thrush and others, 1968.) See bump.

break angle The angle (less than the limit angle) that the break line makes relative to a vertical reference.

break line A straight line from the edge of the mine area to the point of maximum extension at the surface.

breaks "In geology and mining, the term refers to a class of rock structures including faults, fractures, cracks, and small cavities found in rocks, especially during mining." (Stokes and Varnes, 1955.)

breakthrough See crosscut.

bump Rock bursts in coal mines commonly are called bumps. Bumps were defined by Holland and Thomas (1954, p. 3) as follows: "Coal and adjoining rock when subjected to a gradually increasing load $* * *$ usually adjust gradually by slow failure of the pillar or by slow flow of the bottom and (or) top shales. Occasionally, however, the failure is sudden and explosivelike; a mass of coal may be expelled violently from the pillar, or the whole pillar may crush. In some areas the floor may heave suddenly. The failure is usually accompanied by a very loud report, and tremors or vibrations are set up in the earth and in the mine atmosphere that can be detected some distance away. A failure of this kind may affect only a single pillar, part of a pillar, or several pillars, with varying degrees of violence ***. Many names have been applied to these occurrences, such as bump, bounce, crump, mountain shot, pillar burst, pressure burst, rock burst, pounce, quake, and several others ***." Holland and Thomas do not distinguish the failure (strain energy release) from its effects (shock wave, airblast, noise, mine damage, etc.). Most of these names were applied to the failures by miners, and, commonly, miners in different districts applied different names to the same phenomenon; for 
example, in the Utah coal fields "bounce" is used commonly instead of "bump." Hard-rock miners use the term "burst" to describe a type of failure that coal miners call "bump" or "bounce."

bumpy beds Local term used by the Sunnyside miners referring to a mine roof containing numerous small, closely adjacent load casts as much as $12.7 \mathrm{~cm}(5 \mathrm{in}$.) in diameter.

burst See bump.

cannel coal Term now used for sapropelic coal containing spores, in contrast to sapropelic coal containing algae, which is termed boghead coal. "Viewed microscopically, cannel coal shows no stratification. It is generally dull and has a more or less pronounced waxy luster. It is very compact and fractures conchoidally." (Thrush and others, 1968.)

cap See crossbars.

car dump A device used to empty mine cars automatically by turning them over until empty, then righting them and returning them to the track.

cave-in (caving) "To fall in or collapse as an excavation or mine." (Stokes and Varnes, 1955.)

chain pillar "A pillar left to protect the gangway and airway, and extending parallel to these passages." (Thrush and others, 1968.)

circular coal See eye coal.

cleat "a. Main joint in a coal seam, along which it breaks most easily. Runs in two directions, along and across the seam $* * *$. f. Systems of joints, cleavage planes, or planes of weakness found in coal seams. The more pronounced points are called face cleats and are normally parallel to the line or direction of regional folding. It is common for a set of joints, which are approximately parallel cracks or fissures a few inches apart, to occur though they are not as well developed and usually are nearly at right angles to the face cleats. These are known as butt cleats. g. Coal seams are usually intersected by a series of inclined joints which are often well developed. These joints have received distinctive names, such as cleat or slips, though bord is sometimes employed. Usually there are two distinct systems of joints coursing at roughly right angles to each other. The term cleat or face cleat is applied to the major joints and end cleats to the minor joints $* * *$. h. Joints in coal more or less normal to the bedding planes." (Thrush and others, 1968.)

cleavage "***. b. A tendency in rocks to split along definite, parallel, closely spaced planes which may be highly inclined to the bedding planes. It is a secondary structure, commonly confined to bedded rocks, developed by pressure, and ordinarily accompanied by at least some recrystallization of the rocks. Cleavage should not be confused with the fracturing of rocks, which is called jointing. See also joint ***" (Thrush and others, 1968.)

collar See crossbars.

creep An imperceptibly slow and more or less continuous downward and outward movement of slope-forming soil or rock. Creep may affect only the top layer of a slope and, thus, result not only from gravity but also from the influence of freezing and thawing, alternate wetting and drying, and thermal forces, or the movement may be deep-seated under the action of gravity alone. In creep, the movement is essentially viscous under shear stresses sufficient to produce permanent deformation but too small to produce shear failure, as in a landslide. (Stokes and Varnes, 1955.)

crestline (or crest) A line connecting the highest points of the same bed in an infinite number of cross sections. There is a separate crest for each bed (Billings, 1954).

crib "***. b. A structure composed of frames of timber laid horizontally upon one another, or of timbers built up as in the walls of a $\log$ cabin ***. i. To support walls of an excavation by lining the opening with timbers and boards." (Thrush and others, 1968.)

crossbars The horizontal roof member of a timber set on mine roadways or a flat roof supported by props (or roof bolts) on the face. (Thrush and others, 1968.)

crosscut "a. A small passageway driven at right angles to the main entry to connect it with a parallel entry or air course $* * *$. f. In room and pillar mining, the piercing of the pillars at more or less regular intervals for the purpose of haulage and ventilation. Synonym for breakthrough ***." (Thrush and others, 1968.) A subordinate road connecting two other more important roads.

deformation "Change in the form or in the dimensions of a body; produced by stress." (Thrush and others, 1968.)

destressed zone $" * * *$. b. A region of low stress behind the walls of a stoped-out (mined-out) region ***." (Thrush and others, 1968.)

double room system See room and pillar.

double-stall See room and pillar.

drop outs A type of roof cave, roughly dome shaped, occurring at the intersections of openings. eye coal "Coal characterized by small circular or elliptical structural disks or eyes arranged in parallel planes either in, or normal to, the bedding and having shiny surfaces that reflect light like small mirrors ***." (Thrush and others, 1968.) Syn: circular coal. Etymol: German Augenkohle, "eye coal." 
"fingers in the roof" A term used by the Sunnyside miners to describe numerous elongated, irregularly tubular fossil burrows.

floor "a. The rock underlying a stratified or nearly horizontal deposit, corresponding to the foot wall of more steeply dipping deposits ***. $\mathrm{f}$. The upper surface of the stratum underlying a coal seam. g. The bottom of a coal seam or any other mineral deposit $* * *$." (Thrush and others, 1968.)

floor anticlines A result of upward bending of rock layers in floors by laterally directed stresses. Miners of the Sunnyside district refer to them as heaves.

fracture " $* * *$. 2. A crack in a rock large enough to be visible to the unaided eye. It may be a joint, fault, or fissure, but use of the term usually implies that the surfaces of the break are not in absolute contact." (Stokes and Varnes, 1955.)

fusain "a. A dull hard constituent of banded bituminous coal. It closely resembles charcoal and occurs in strands and patches. Microscopically it appears dull and nearly opaque but may show cellular wood structure. Unmineralized fusain is soft and contributes the large proportion of dust in coal mines. Because of its porosity, however, it is commonly impregnated with calcite, pyrite, or kaolinite. Such fusain is hard." (Stokes and Varnes, 1955.) "b. A coal lithotype characterized by its silky luster, fibrous structure, friability, and black color. It occurs in strands or patches and is soft and dirty when not mineralized. Its characteristic microlithotype is fusite ***." (Gary and others, 1972.)

hard cutting coal Coal that resists the action of a continuous miner or cutting machine.

haulage, haulage road, or haulageway "The gangway, entry, or tunnel through which loaded or empty mine cars are hauled by animal or mechanical power." (Thrush and others, 1968.)

header block As used at Sunnyside, Utah, a large timber block drilled in the center and held against the roof by a roof bolt in order to distribute the stress resulting from tensioning of the bolt.

heading and stall See room and pillar.

heave " $* * *$. b. A rising of the floor of a mine caused by its being too weak to resist the weight on the pillars ***." (Thrush and others, 1968.)

horseback(s) A local term used in the Sunnyside district for rock layers that sag markedly downward into openings under unsupported roofs or roofs that are only lightly supported. They are nearly parallel to slopes. These features result from lateral stresses in the lowermost beds of the roof. Syn: roof syncline.

horizontal burrows Branching tabular cavities, nearly parallel to bedding, that were formed by organisms which lived below the surface of the original sediments. The cavities are now filled with fine-grained sand. At Sunnyside, the burrows have oval cross sections and are between 10 and $60 \mathrm{~mm}$ (0.4 and 2.4 in.) in maximum diameter. (Maberry, 1971, p. 16.)

interbedded Occurring between beds or alternating with other beds of different character; referring to rock material laid down in sequence between other beds, such as a contemporaneous lava flow "interbedded" with sediments. (Modified from Gary and others, 1972.)

interdigitation See intertongued.

interfingering See intertongued.

intertongued, intertonguing "The disappearance of sedimentary bodies in laterally adjacent masses owing to splitting into many thin units (tongues), each of which reaches an independent pinch-out termination; the intergradation of markedly different rocks through a vertical succession of thin interlocking or overlapping wedge-shaped layers. Syn: interfingering, interdigitation" (Gary and others, 1972.)

isomers "Substances composed of equal amounts of the same elements but differing in properties due to variation in structure." (Thrush and others, 1968.)

isometric projection "In technical drawing, a three-dimensional view of an object drawn to scale with three perpendicular edges at $120^{\circ}$ to each other and with vertical lines oriented vertically." (Thrush and others, 1968.)

joint "A fracture or parting plane along which there has been little if any movement parallel with the walls." (Stokes and Varnes, 1955.) See cleavage.

kaolin See kaolinite.

kaolinite a. A common, white to gray or yellow clay mineral of the kaolin group: $\mathrm{Al}_{2} \mathrm{Si}_{2} \mathrm{O}_{5}(\mathrm{OH})_{4}$. "It is the characteristic mineral of most kaolins and is polymorphous with dickite and nacrite. Kaolinite consists of sheets of tetrahedrally coordinated aluminum; it is a high-alumina clay mineral that does not appreciably expand under varying water content and does not exchange iron or magnesium. The mineral was formerly known as kaolin. b. A name sometimes applied to the kaolin group of clay minerals and formerly applied to individual minerals of that group (such as to dickite and nacrite)." (Gary and others, 1972.)

lagging "a. To secure the roof and sides behind the main timber or steel supports with short lengths of timber, sheet steel, or concrete slabs. Lagging wedges secures the supports against the rock and provides early resistance to pressure. If concrete slabs are used, they are made in lengths to fit between the arch webs. The (timber) lagging behind steel arches in 
tunnels may be pyrolith-treated, fire-resisting boards, also called lacing $* * *$. c. In shafts, planks, usually $5 \mathrm{~cm}(2 \mathrm{in}$.) thick, placed on the outside of sets $* * *$. e. Planks, slabs, or small timbers placed over the caps or behind the posts of the timbering, not to carry the main weight but to form a ceiling or a wall, preventing fragments of rock from falling through $* * *$." (Thrush and others, 1968.)

landing mats Perforated rectangular steel plates designed to interlock and to provide a temporary landing strip for aircraft. Used in Sunnyside mines to provide supplemental roof support by fastening them to roof with roof bolts.

limit angle See angle of draw.

limit line A straight line from the edge of the mine area to the limit of measurable subsidence at the surface.

load cast(s) The bulbous, mammillary or papilliform downward protrusions of sand into clayey rocks. These protrusions are produced by load deformation due to yielding under unequal load, of underlying hydroplastic mud. (Thrush and others, 1968.)

longwall mining "A method of coal mining in which the coal is mined in a single, continuous operation. The emptied space is either filled with some packing material or is allowed to collapse." (Gary and others, 1972.) See pillar method of working.

manway “***. b. A passageway for the use of miners only; an airshaft; a chute ***. c. Eng. A manhole ***. d. A passage in or into a mine used as a footpath for workers ***." (Thrush and others, 1968.)

mining face Any surface on which active mining operations are in progress. "The solid surface of the unbroken portion of the coal bed at the advancing end of a working place." (Thrush and others, 1968.)

mine openings The parts of coal mines between the pillars or between the pillars and ribs.

motor roads As used at Sunnyside, refers to the mine openings along which track is laid for use of haulage motors. (Thrush and others, 1968.) See also motorway.

motorman "The man who operates a haulage locomotive." (Thrush and others, 1968.)

motorman's shelter A room constructed of cement blocks inside a mine where motormen may wait for loaded cars if necessary.

motorway A road designed and reserved for use only by power-driven vehicles. (Thrush and others, 1968.) See motor roads.

openings The parts of coal mines between the pillars or between the pillars and ribs. (Thrush and others, 1968.)

orthogonal joint system A related number of joint sets that intersect each other at right angles.

outburst(s) "a. The name applied to the violent evolution of gaseous firedamp (methane) (usually together with large quantities of coal dust) from a working face. Outbursts are known wherever coal is worked $* * *$. b. The occurrence is violent and may overwhelm the workings and fill the entire district with gaseous mixtures. Roadways advancing into virgin and stressed areas of coal are particularly prone to outbursts in certain seams and faults that often intersect the area. Syn: blowout $* * *$." (Thrush and others, 1968.)

parting $" * * *$. b. A side track or turnout in a haulage road. Entry parting, the parting at the beginning of an entry in a slope mine. Inside or swing parting, a parting some distance from the mouth of an entry, from which the cars are hauled out by a special mule or team. Rope parting or motor parting, a parting on which trips of cars are collected for hauling out by a rope-haulage system or electric motor ***. d. A side track or turnout in a haulage system, having a track for loads and a track for empties ***." (Thrush and others, 1968.) e. At Sunnyside, the "main parting" is the place where haulage motors set out empty cars to be lowered down the slope by cable and where loads pulled up are set out for the motors to take away.

pillar "a. An area of coal or ore left to support the overlying strata or hanging-wall in a mine. Pillars are sometimes left permanently to support surface works or against old workings containing water. Coal pillars, such as those in pillar-and-stall mining, are extracted at a later period. See also barrier pillar; ***. b. A solid block of coal, etc., varying in area from a few square yards to several acres $* * *$. c. The part of coal left between the individual rooms and entries in room-and-pillar mining ***." (Thrust and others, 1968.)

pillar line An alignment of pillars adjacent to a worked-out area.

pillar method of mining "Methods of working coal seams, which have been given different names in different coalfields, such as stoop-and-room in Scotland; bord-and-pillar in Durham, England; and single and double stalls in South Wales. There are many modifications of pillar mining, but in general, there are two stages: (1) the driving of narrow roadways and thus forming a number of coal pillars, and (2) the extraction of the pillars-often on the retreating system. Pillar methods of mining are widely used in the United States, while the longwall method is favored in Great Britain. Pillar methods are also used for working stratified deposits of ironstone, rock salt, slate and other layered minerals." (Thrush and others, 1968.) 
post-and-stall See room and pillar.

raise An inclined opening driven up the dip of the coal bed. A "raise parting" is installed at the intersection of a main haulage entry with the raise.

rib "a. The side of a pillar or the wall of an entry***. b. The solid coal on the side of a gallery or longwall face; a pillar or barrier of coal left for support ***." (Thrush and others, 1968.)

rider coal "***. c. A thin coal seam above a workable seam, or a seam which has no name * **." (Thrush and others, 1968.)

rock burst See bump.

rock tunnel "A tunnel, drift, or crosscut driven through rock, usually connecting one coalbed with another; also driven through barren rock in metal mines." (Thrush and others, 1968.)

roof bar See crossbars.

roof shale "The layer or seam of shale occurring immediately above the coal bed. This shale or slate must be removed in mining operations." (Modified from Thrush and others, 1968.)

roof synclines Synclines that occur in unsupported roofs, or in roofs that are only slightly supported, where thin layers sag downward into openings. They are nearly parallel to slopes. These features result from lateral stresses in the lowermost beds of the roof. See horseback(s)

room-and-pillar A system of mining in which the distinguishing feature is the removal of 50 percent or more of the coal or ore in the first working. The coal or ore is mined in rooms separated by narrow ribs or pillars. The coal or ore in the pillars is removed by subsequent working, which may be likened to top slicing, in which the roof is caved in successive blocks. The first working in rooms is an advancing, and the winning of the rib (pillar) is a retreating method. The rooms are driven parallel to one another, and the room faces may be extended parallel, at right angles, or at an angle to the dip. This method is applicable to flat deposits, such as coal, iron ore, lead, zinc, etc., that occur in bedded deposits. Modifications of this method are the following: County of Durham system, double-entry room-and-pillar mining, double-room system, double-stall working, heading and stall, pillar-and-stall, post-and-stall, room-and-stoop, single-entry room-and-pillar mining, single-stall working, square work, stall-and-breast, and triple-entry room-and-pillar mining. (Thrush and others, 1968.)

shatter zone Volume of rock or coal that is broken by numerous cracks or fissures trending in many directions.

shot-firer "***. a. A man whose special duty is to fire shots or blasts, especially in coal mines ***." (Thrush and others, 1968.)

simple cleavage Cleavage with smooth planes that are most common within and parallel to the walls of shatter zones. They do not parallel the individual uneven fractures making up a shatter zone. See cleavage.

single-stall working See room and pillar.

slickenside "The polished, grooved, and striated surface produced on rocks by movement along a fault or sometimes at the bottom of a landslide. The grooves are parallel to the direction of movement, but they may be straight or curved. The term usually appears in the plural." (Stokes and Varnes, 1955.)

split(s) “***. f. A bench separated by a considerable interval from the other benches of a coal bed $* * *$. h. A layer of coal which has separated from its parent seam. Seam splitting is often detrimental as it may separate a coal seam of workable thickness into two or more layers which are too thin for economic mining ***. i. The upper or lower portion of a divided coal seam $* * *$. j. The division of a bed of coal into two or more horizontal sections by intervening rock strata ***." (Thrush and others, 1968.)

spotted cleavage Small parallel fracture planes (cleavage) in coal that commonly show smooth, nearly circular spots making up what is known as "eye coal." See eye coal.

square work See room and pillar.

squeeze a. The gradual increase in load on tunnel or mine supports with some movement of ground around resisting support members. b. The gradual closing of a mine working by the settling of the overlying strata. c. The fracturing, crushing, or downward bending of the roof strata over a mine working; the gradual upheaval of the floor of a mine due to the weight of overlying strata. d. A mine area (such as a section in a coal seam) undergoing a squeeze. (Modified from Gary and others, 1972.)

stall-and-breast See room and pillar.

strain "Deformation caused by stress. Technically, strain is the elongation or shortening per unit of original length of a body under tension or compression, or the distortion in angle between two planes in a body under shear stress." (Stokes and Varnes, 1955.)

strain energy "***. b. The work done in deforming a body within the elastic limit of the material. It is more properly defined as elastic strain energy and can be recovered as work rather than heat ***." (Thrush and others, 1968.)

stress "The intensity at a point in a body of the internal forces or components of force that act on a given plane through the point. Stress is expressed in force per unit of area (pounds per square inch, kilograms per square millimeter, etc.). As used in product specifications, stress 
is calculated on the basis of the original (Note 1) dimensions of the cross section of the specimen. Note 1.-In this and other definitions $* * *$ "original refers to dimensions, area, etc., of specimens before the beginning of testing. Note 2.-The stress or components of stress acting perpendicular to a given plane is called the normal stress. A normal stress may be either a tensile stress or a compressive stress depending upon the nature of the force. The stress or component of stress acting tangential to the plane is called the shearing stress. Note 3.- "True Stress" differs from stress as defined previously in that it is calculated from the instantaneous rather than original area $* * *$." (Stokes and Varnes, 1955.)

talking coal Term applied to a series of small bumps or cracking noises that indicate a change in conditions within coal or rock that is beginning to yield to stress.

timber prop(s) a. Underground supporting post set across the lode, seam, bed, or other opening. b. In mining, a roof support, usually temporary. c. A timber set upright or at right angles to the dip, to support the roof rock. (Modified from Thrush and others, 1968.)

tongue a. A minor rock-stratigraphic unit of limited geographic extent, being a subdivision of a formation and similar in rank to a member, and disappearing laterally (usually by facies change) in one direction; "a member that extends outward beyond the main body of a formation." b. A lateral extension of a formation, wedging out in one direction between strata of a different kind and passing in another direction into a thicker body of similar rock type ***. v. "To thin laterally to disappearance ***." (Gary and others, 1972.)

vitrain "This term was introduced by M.C. Stopes in 1919 to designate the macroscopically recognizable, very bright bands of coals. Very bright bands or lenses, usually a few millimeters (3-5 in.) width; thick bands are rare. Clean to the touch. In many coals the vitrain is permeated with numerous fine cracks at right angles to stratification, and consequently breaks cubically-with conchoidal surfaces. In other coals the vitrain is crossed by only occasional perpendicular cracks. In the macroscopic description of seams only the bands of vitrain having a thickness of several millimeters are usually noted $* * *$." Occurs in lenticular bands, each derived from a single piece of original vegetable growth. When it constitutes below 15 percent of total seam, termed sparse; between 15 and 30 percent, moderate; 30 to 60 percent of total seam, termed abundant; over 60 percent, dominant. (Thrush and others, 1968.)

wind road See airway.

work "As a verb, to undergo gradual movement, such as heaving, sliding, or sinking; said of rock materials." (Gary and others, 1972.)

yield(ed) zone Zone of deformed coal or rock in which strain is no longer proportional to stress, and which consequently cannot transmit increased load. 


\title{
COAL MINE BUMPS AS RELATED TO GEOLOGIC FEATURES IN THE NORTHERN PART OF THE SUNNYSIDE DISTRICT, CARBON COUNTY, UTAH
}

\author{
By FRANK W. OSTERWALD ${ }^{1}$, C. RICHARD DUNRUD, and DONLEY S. COLLINS
}

\begin{abstract}
Coal mine bumps, which are violent, spontaneous, and often catastrophic disruptions of coal and rock, were common in the Sunnyside coal mining district, Utah, before the introduction of protective-engineering methods, modern room-and-pillar retreat mining with continuous mining machines, and particularly modern longwall mining. The coal at Sunnyside, when stressed during mining, fails continuously with many popping, snapping, and banging noises. Although most of the bumps are beneficial because they make mining easier, many of the large ones are dangerous and in the past caused injuries and fatalities, particularly with roomand-pillar mining methods used in the early mining operations.

Geologic mapping of underground mine openings revealed many types of deformational features, some pre-mine and some post-mine in age. Stresses resulting from mining are concentrated near the mine openings; if openings are driven at large angles to small pre-mine deformational features, particularly shatter zones in coal, abnormal stress buildups may occur and violent bumps may result. Other geologic features, such as ripple marks, oriented sand grains, intertongued rock contacts, trace fossils, and load casts, also influence the occurrence of bumps by impeding slip of coal and rocks along bedding planes. The stress field in the coal also varies markedly because of the rough ridge and canyon topography. These features may allow excessively large stress components to accumulate. At many places, the stresses that contribute to deformation and failures of mine openings are oriented horizontally. The stratigraphy of the rocks immediately above and below the mined coal bed strongly influences the deformation of the mine openings in response to stress accumulations.

Triaxial compressive testing of coal from the Sunnyside No. 1 and No. 3 Mines indicates that the strength of the coal increases several times as the confining (lateral) stress is increased. Strengths of cores cut from single large blocks of coal vary widely. Although the strengths of coal cores increase slowly at high levels of confining stress, the coal in Sunnyside No. 1 Mine is slightly stronger in laboratory tests than coal in Sunnyside No. 3 Mine. The coal in No. 1 Mine probably can store larger amounts of stress than coal in the No. 3 Mine, which may account for the apparently greater number of violent bumps in No. 1 Mine. The strength of coal, and its ability to store stress before failure, may correlate in part with chemical composition, particularly with the amounts of benzene ring
\end{abstract}

\footnotetext{
Manuscript approved for publication April 12, 1990.
}

${ }^{1}$ Deceased August 27, 1989. compounds in vitrain; coal with relatively large amounts of benzene ring compounds is stronger than coal with lesser amounts of these compounds. Alternatively, the chemical composition of coal may affect its response to stress. Increasing contents of kaolinite in coal appear to reduce its compressive strength at low confining stresses, resulting in easy failures of pillars and ribs in mine openings.

Applications of the geologic factors outlined in this report, carefully coupled with advanced modern engineering methods, have markedly reduced the hazards from coal mine bumps and related failures of mine openings at Sunnyside. Similar studies probably could aid in reducing bump-related hazards in other coal mining areas.

\section{INTRODUCTION}

Coal mine bumps are violent, spontaneous, and sometimes catastrophic disruptions of coal and rock in mine ribs, faces, floors, and roofs. Bumps, which physically are the same phenomena as rock bursts that occur in many metal mines throughout the world, are a common and continuing hazard to life and property in many coal mines. The Sunnyside, Utah, district was selected in 1958 for a U.S. Geological Survey (USGS) investigation of coal mine bumps because the mines in the northern part of the district (figs. 1, 2; Osterwald and others, 1981, p. 1-2) are economically important as a major source of bituminous coking coal for the steel industry in the Western United States, because violent and hazardous bumps were known to occur there frequently, and because its surface geology could be conveniently studied. This investigation was begun at the request of and in cooperation with the U.S. Bureau of Mines (USBM). Active cooperation with the USBM continued until 1961; after 1961 the work was carried on by the USGS alone until 1977, although informal cooperation with the USBM took place in the field until 1966.

The early phases of the work revealed that bumps are only one inseparable facet of a complex problem of coal mine deformation. Consequently, the studies were 


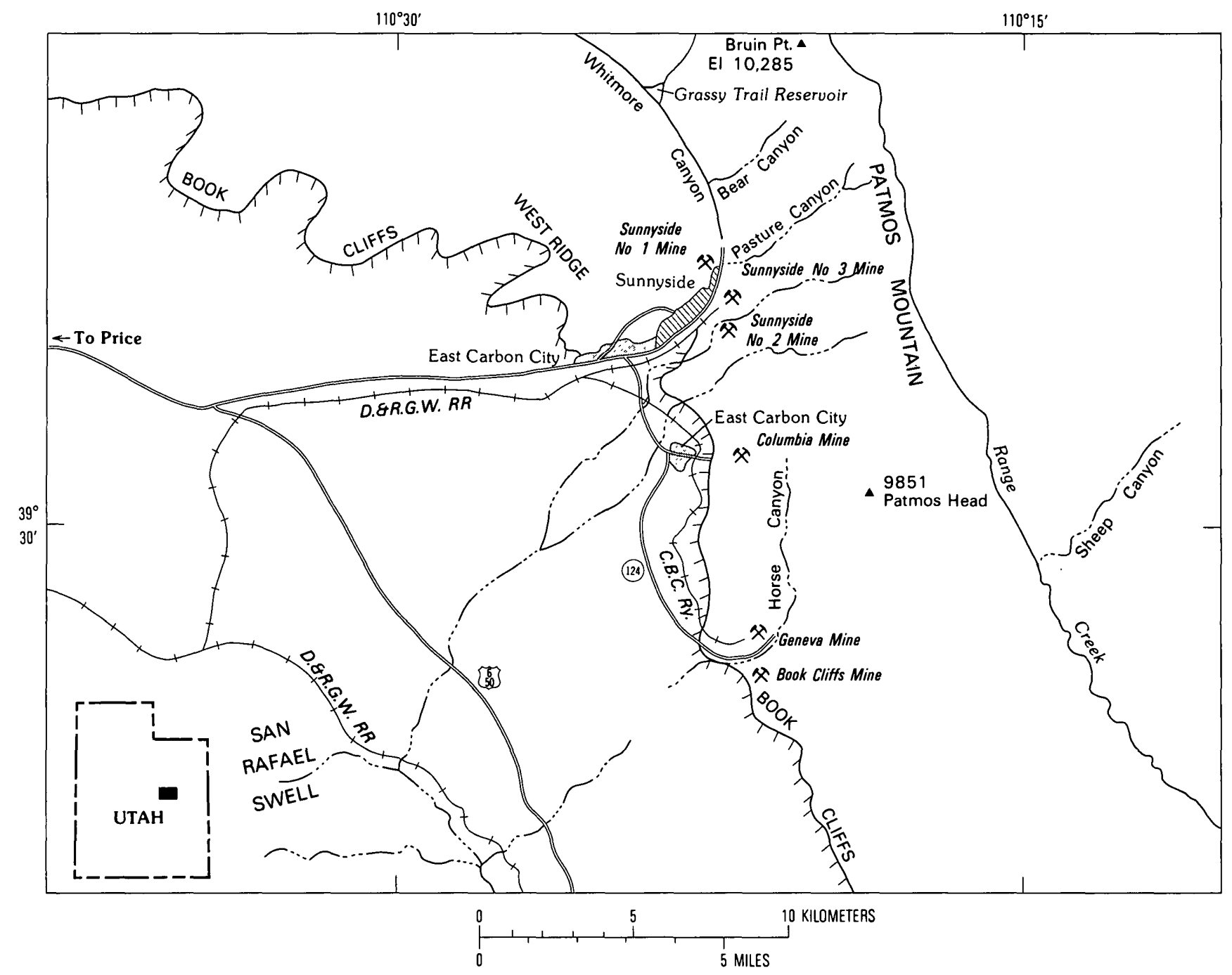

FiguRE 1.-Index map of Utah showing Sunnyside coal mining district (indicated by solid rectangle on inset map) and mines and major features within the district. Denver and Rio Grande Western Railroad, D. \& R.G.W. R.R. Carbon County Railway, C.B.C. Rwy. Town boundaries of East Carbon City shown by light stipple pattern; town of Sunnyside shown by diagonal line pattern.

expanded to include other engineering geologic aspects of mining in the Sunnyside district: surface subsidence, gas inflows, roof caves, floor heaves, and squeezes, as well as related studies at the ground surface of landslides, engineering properties of bedrock and surficial units, and structural behavior of rock units.

This report summarizes the geologic work related directly to deformation of mine openings in the northern part of the Sunnyside district from 1958 to 1970; it is one of a series of reports describing the geology, seismicity, and mining in the district (Osterwald, 1962b; Osterwald and Dunrud, 1966; Osterwald and others, 1969, 1971; Maberry, 1971; Dunrud and Barnes, 1972; Osterwald and Maberry, 1974; Dunrud, 1976). Background information describing the bedrock, surficial, and economic geology of the district was presented earlier by Osterwald and others (1981). In compiling this report we have attempted to make it useful both to geologists who may not be familiar with coal mining terminology and to miners who may not recognize geologic terminology for features they see every day. The geologists are referred to Thrush (1968) for definitions of coal mining terms and the coal miners to Gary and others (1972) for definitions of geologic terms. We have provided a glossary of most of the geologic and mining terms used in this report. In the glossary, as well as when the terms are first used in the text, and/or at their primary usage, these terms appear in boldface ${ }^{2}$. The terminology used in strength testing of rocks is described in the section on testing. Because English (inch-pound) units of measurement are still in

${ }^{2}$ NOTE. Some terms in the glossary are not included in the text but are used in the figures, plates, or tables. 
common use in most coal mines (and are required by law in some States), we have included both metric and English units. All the field surveys and most of the laboratory measurements were done using English units; metric equivalents were calculated later. Most of the localities we studied underground were abandoned, mined out, or covered by steel arches, lagging, and backfilling by 1981 . We have, therefore, described many features in underground mines that no longer exist or are completely inaccessible.

\section{ACKNOWLEDGMENTS}

Special thanks are due several geologists who helped in the difficult, commonly unpleasant, and sometimes hazardous underground mapping in the district, especially to R.E. Eggleton, Harold Brodsky, and J.O. Maberry. D.J. Varnes initiated the geologic work in the Sunnyside district, participated actively in the early investigations, and actively encouraged all of the work. Osterwald carried on the work assisted at various times by Eggleton, Brodsky, J.O. Duguid, Jr., B.K. Barnes, and Maberry. C.R. Dunrud joined the project in 1961, participating in all phases of the work since that time. D.S. Collins prepared the final copy for the maps, graphs, and sketches; helped assemble the mass of material; and participated in rewriting the text. Many thanks to Thomas Kohnen for his meaningful technical conversations and for his final review of the manuscript.

Many individuals employed by the mining companies working in the district contributed greatly to our investigations through discussions of problems of mutual interest, by providing logistical support, and through their interest and encouragement during the course of the study. John Peperakis, of Kaiser Steel Corporation, and R.M. von Storch, of United States Steel Corporation, gave ready access to the properties under their control and were always willing to discuss problems or progress during the work. Many members of the engineering staffs of their companies, particularly D.M. Heileman, R.J. Bowen, J.T. Taylor, R.E. Yourston, L.F. Huntsman, J.B. McKean, and Harry Elkin, were very helpful in contributing their knowledge of mining in the district. T.R. McCourt, J.A. Harvey, and Frank Markosek, former mine superintendents in the northern part of the district, made it possible for us to work in their mines and helped immeasurably by discussing many problems in the light of their long experience with bumps and mine deformation.

J.C. Witt, a commercial photographer in Helper, Utah, who had much experience in underground coal mining and also held a shot-firer's certificate, was invaluable in helping further to illustrate many of the features mapped in the mines. L.D. Fredrickson, Jr., of Spectran Laboratories (Denver, Colo.), made the infrared spectral analyses of coal and helped in their interpretation. Faye F. Neuerburg also helped interpret the spectra and explain the complex organic compounds.

Many members of the staff of the USBM contributed directly and indirectly to the investigations. Their contributions were particularly valuable because of the Bureau's long history of research into engineering problems related to coal mine bumps. We acknowledge particularly the aid given by E.R. Rodriguez, F.L. Gaddy, and T.C. Miller, who were active in the first cooperative phases of work. Their testing of coal samples provided a basis for much of our subsequent laboratory work. D.J. Varnes and F.W. Osterwald participated in their testing and in selecting sample localities at Sunnyside. P.J. Mudra and J.C. Hartley conducted parallel instrumentation studies in the Sunnyside mines, and our numerous discussions were very helpful. D.S. Kingery, James Westfield, A.J. Barry, and Edward Thomas, through their active interest and encouragement, made our investigations possible.

We are particularly indebted to Jerome Hernandez of Sunnyside, Utah, who was always ready to help with a difficult job or to share his knowledge of the Book Cliffs region and of mining problems at Sunnyside. Mr. Hernandez always encouraged our early work as a friend and neighbor, and after he joined the USGS his experience and skill were invaluable, both during underground investigations of bumps and roof falls and during surface mapping and many other studies related to this report.

\section{GEOLOGIC FEATURES}

Coal is mined in the Sunnyside district from an informally named upper mudstone member of the Blackhawk Formation of Late Cretaceous age (Maberry, 1971, p. 30; Osterwald and others, 1981, p. 17-20). The Sunnyside coal bed, which locally is more than $6 \mathrm{~m}(20 \mathrm{ft})$ thick, overlies a layer of finegrained sandstone and coarse-grained siltstone about $46 \mathrm{~m}$ (150 ft) thick. In some places, less than $2 \mathrm{~m}$ (a few feet) of carbonaceous siltstone or shale separates the sandstone and coal. Splits from the major coal bed are common, and some thin partings of carbonaceous shale and siltstone occur within the coal (Brodsky, 1960 , p. 36; Maberry, 1971, p. 30; Osterwald and others, 1981, p. 56-58). As first recognized by Brodsky (1960, p. 36), the units known to miners as the "Upper Sunnyside Coal Bed" and "Lower Sunnyside Coal Bed" probably are splits of the same bed. Above the Sunny- 


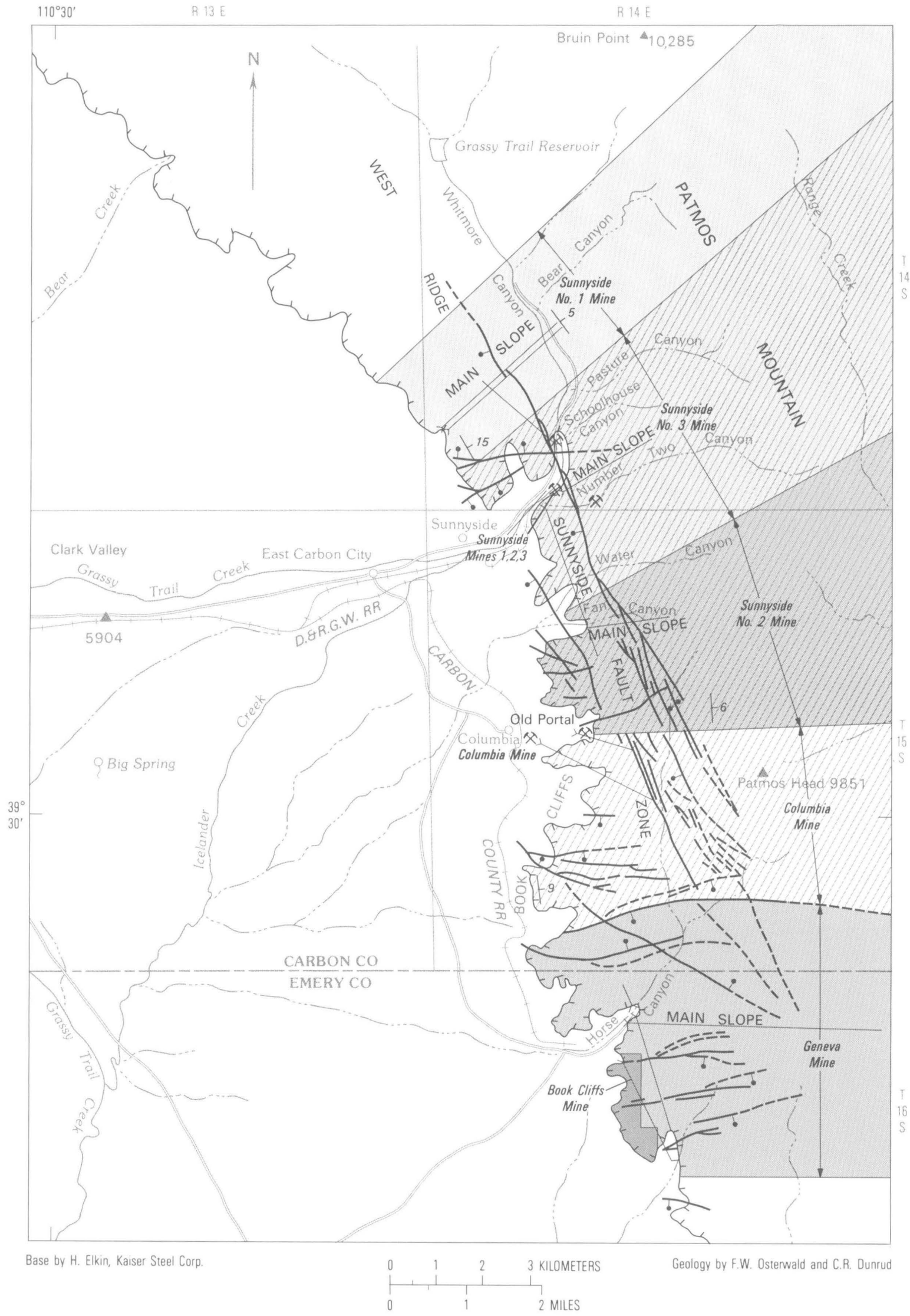




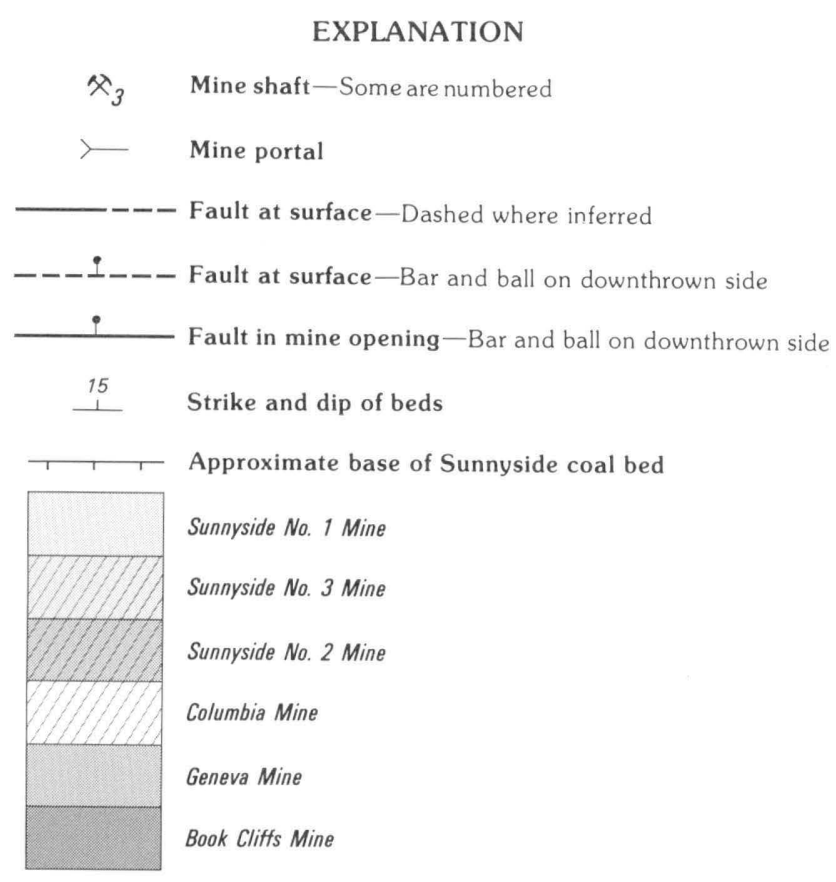

Figure 2 (above and facing page).-Boundaries of coal mines and major geologic features in the Sunnyside coal mining district.

side coal is about $75-90 \mathrm{~m}(250-300 \mathrm{ft})$ of variable, intertongued and interbedded mudstone and sandstone (Maberry, 1971, p. 30) locally containing large channel sandstones. These channel sandstones become more common upward, and many merge or branch to form larger or smaller structures. The thick-bedded, uniform Castlegate Sandstone, about $60 \mathrm{~m}(200 \mathrm{ft})$ thick, overlies the mudstone and sandstone. Above the Castlegate is the Price River Formation which includes a lower unnamed member of argillaceous sandstones about 45-90 m (150-300 ft) thick and the Bluecastle Sandstone Member that is $3-90 \mathrm{~m}(10-300 \mathrm{ft})$ thick (Osterwald and others, 1981, p. 20-22).

In the Sunnyside district the beds commonly dip about $5^{\circ}$ to the east and northeast, except at their outcrops along Book Cliffs (fig. 1) on the west side of the Sunnyside No. 1 Mine area where they dip as much as $15^{\circ}$. The strike of beds is nearly north in the southern part of the district but changes gradually to northwest in the northern part of the district.

Steeply dipping faults nearly parallel to both the strike and the direction of dip of beds cut the Sunnyside district. We mapped the northwest-trending Sunnyside fault zone in many mine openings and at the surface. The fault zone is a belt of fractures about $1930 \mathrm{~m}(1.2 \mathrm{mi})$ wide in the southern part of the district, but it narrows to a single break in the northern part of the district. It dips almost vertically, and the stratigraphic separation across the zone is commonly about $9 \mathrm{~m}$ (30 ft). The southwest side is downthrown. Northeast- to east-trending faults, about parallel to the direction of dip, cut the coal beds near the face of the Book Cliffs. Maximum stratigraphic separation is about $40 \mathrm{~m}(130 \mathrm{ft})$ at the Book Cliffs but decreases markedly toward the northeast.

\section{STRESS HISTORY OF THE COAL}

The stress history of the coal bed at Sunnyside is closely linked to the regional Quaternary history, although the coal may have been subjected to some differential stresses as a result of uplift and subsequent erosion that sculptured the region into broad valleys and ranges during late Tertiary time (Hunt, 1956 , p. 82-83). An outcrop of coal peripheral to the San Rafael Swell (fig. 1) probably was exposed during the late Tertiary. Lateral stresses in the coal, directed nearly at right angles toward this outcrop, formed as resultants of vertical stress (overburden load) because of Poisson's Effect in the coal. The fault and joint patterns in the district (Osterwald and others, 1981, p. 43-52) and the pre-mine structural features in the coal presumably were already formed by this time. They probably resulted from diastrophic activity earlier in Tertiary time.

The coal outcrop probably was eroded toward the present position of the Book Cliffs before and during cutting of pediments in front of the cliffs in preWisconsin time (Osterwald and others, 1981, p. 26-28). As the steepness of the cliff front increased and the elevation of the coal outcrop decreased because of its eastward and northeastward dip, the magnitudes of the lateral stresses decreased and the magnitudes of the vertical stresses increased. Within the coal beds, many of the smooth cylindrical fractures in the Sunnyside No. 1 Mine that occur in a northwest-trending belt about parallel to the cliffs were formed as a result of this increasing stress.

Because of the variable thicknesses of overburden at closely adjacent places within the coal beds, erosion of valleys and deep canyons in late Pleistocene time caused widely differing vertical and lateral stresses. The V-shaped gorges cut in pre-Wisconsin time in the bottoms of Whitmore Canyon, Horse Canyon, and other deep canyons elsewhere in the district (Osterwald and others, 1981 , p. 41-42) rapidly reduced the amount of vertical stress on the coal in a narrow strip beneath the present canyons. The horizontal (lateral) stresses may have decreased slightly because the rocks and coals were internally restrained. Consequently, strong differential stresses were created between the 
coal under the central parts of the canyons and that under both sides of the canyons. Resolution of these stresses, combined with Poisson's Effect in the coal, probably produced approximately horizontal maximum and minimum stresses in the coal that were oriented at about right angles to the trend of the canyons and directed laterally from both sides of the canyons. Partial refilling of the $\mathrm{V}$-shaped gorges with thick conglomerates in early Wisconsin time probably added as much as one-eighth of the original vertical stress to the coal beneath the canyons, thus reducing the horizontal stresses and in effect recycling the stress field proportionally. Later erosion removed this fill and differentially unloaded the coal again. Younger alluvial fills in the canyons undoubtedly contributed additional vertical stress to the coal, but the fills were thin (probably between 15 and $45 \mathrm{~m}$ (50 and $150 \mathrm{ft}$ ) thick) and may not have significantly restressed the coal. Quaternary events since late Wisconsin time probably were of too small magnitude to markedly influence the stress in the coal. Alternate wet and dry climatic cycles, as indicated by changes in the stratigraphy of surficial materials (Osterwald and others, 1981, p. 24-38), may have induced additional cycles of decreasing and increasing stress on the coal bed by changing the pore-water pressure in beds of the Blackhawk Formation, Castlegate Sandstone, and Price River Formation near the coal. Although these beds contain little or no water at present, they may have contained much water at times during the Pleistocene.

\section{BUMPS}

Bumps are rock bursts in coal mines (Holland and Thomas, 1954, p. 3) that ultimately result from the sudden releases of large amounts of strain energy stored in coal or rock. According to Budd (1968, p. 56-57), coal stores three and two-fifths more strain energy than does the same volume of sandstone when both are subjected to equally high vertical loads and confining stresses. This strain energy is released suddenly and violently when the coal or rock is stressed beyond its elastic limit and fails (Morrison, 1947 , p. 71). Many other names have been applied to such failures, such as bounce, crump, mountain shot, pillar burst, pressure burst, rock burst, pounce, quake, and others (Holland and Thomas, 1954, p. 30). Most of these names were applied by miners to the failures, but miners in different districts commonly used different names for the same or similar phenomena. Bumps primarily are violent, single-phase, shear failures, of any scale, in which fragments of coal and rock are thrown outward from fracture surfaces (Osterwald, 1961, 1962a, b; Bird, 1942, p. 22). They should be distinguished from outbursts or blowouts which are two-phase phenomena wherein dynamic failures of coal faces or ribs are extended by desorption of gas (Farmer and Pooley, 1967, p. 189). Outbursts are failures in which large quantities of gas (commonly methane or carbon dioxide) mixed with coal fragments are released suddenly, flowing outward into the mine openings and leaving cavities in the solid coal.

Bumps, known by local miners as bounces, have plagued the coal mines of east-central Utah for many years. Clark (1928, p. 80), a pioneer geologist in the Book Cliffs coalfield, noted that during mining in 1911 coal faces at Sunnyside continually snapped and splintered. The problem was sufficiently important by 1918 to prompt A. C. Watts, a mining engineer, tentatively to correlate bumps with local tectonic features (Watts, 1918). Bumps continued to present problems with the introduction of modern mining methods; their occurrence and the recent engineering methods of coping with the problems were described by Peperakis (1958). Many bumps, ranging in size from very small to very large, occurred during our investigations in the Sunnyside district.

Mine faces that bumped continuously during roomand-pillar mining still were common in the Sunnyside district in 1970. While modern continuous-mining machines were operated, small to moderately large pieces of coal and rock were ejected continuously from such faces, accompanied by explosionlike reports as loud as those from large-caliber rifles. Occasional loud reports, accompanied by proportionately larger pieces of coal, and reports as loud as those made by small infantry mortars occurred during long periods of machine operation. The louder reports were accompanied by perceptible tremors in the floor, some of which were strong enough to sting the feet of miners or to throw them an inch or so off the floor. During the ejection of pieces of coal and rock, slabs of roof sometimes fell on or near the mining machines, ribs began "to work" and crumble, and floors heaved. All such activity continued at an apparently decreasing rate when mining was temporarily discontinued, but unrelieved stresses were then accumulated behind faces and ribs, leading to larger bumps (and louder reports) when mining was resumed. Occasionally, large bumps occurred during weekends and idle periods.

Small bumps during operation of mining machines actually are beneficial to some degree because they make mining easier, reduce the need for blasting, and relieve stress accumulations behind faces, reducing the probability of large bumps. Unwary personnel, however, may be killed or injured by even small bumps; deaths have occurred when single, football-sized pieces of coal were ejected suddenly from highly stressed ribs. 


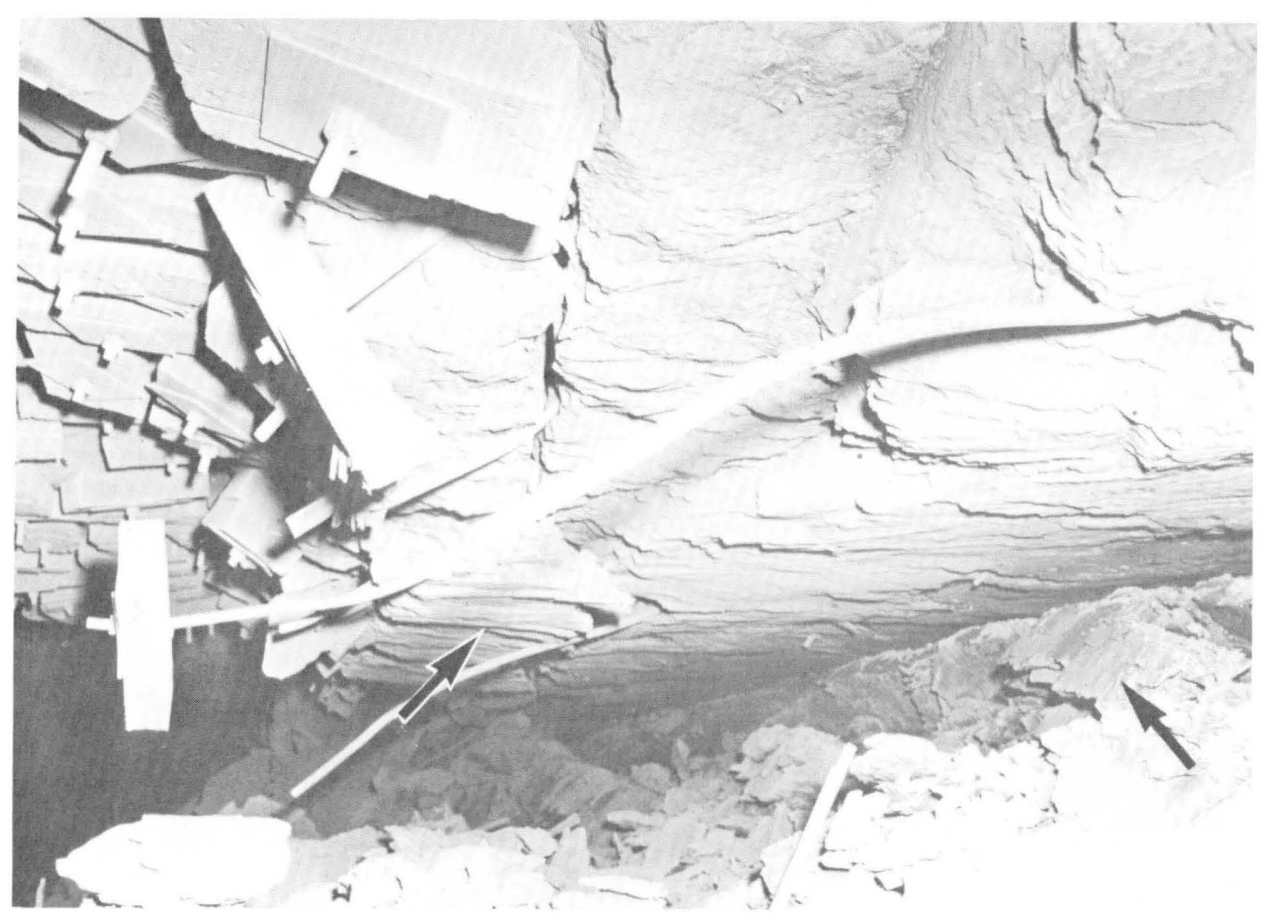

Figure 3.- View down right-side manway, Sunnyside No. 1 Mine, Utah, near lower (downdip) end of rock mass that resulted from bump (burst), December 4, 1957. Laterally directed components of force are indicated by bent roof bolts $2.5 \mathrm{~cm}$ (1 in.) in diameter and crudely slickensided bedding and fracture surfaces (arrows). Caving of roof was aided by prominent joints. Photograph by J.C. Witt.

Property may be damaged similarly during small bumps that occur near machinery, supports, or mining material.

During the former hand-mining days, when most coal was removed by picks and shovels, many miners used bumps to their advantage. At the start of a work shift, they would throw a pick at the coal face, which had not been mined for at least a few hours. The impact of the pick caused the face to bump, throwing out enough coal so that the entire working shift could be devoted to shovelling coal into mine cars (Jerome Hernandez, oral commun., 1959).

Many coal miners believe they can foretell large bumps by the actual mining conditions at the face. According to these miners, large bumps are apt to occur when the coal becomes "hard to cut" with mining machinery. Whether such a correlation actually exists is difficult to determine. Bumps may occur without such premonitory sensations, and hard cutting coal is not always followed by a bump. Other presumed premonitory sensations include talking coal and timber props, in which small popping, grumbling, and groaning noises are thought to become more abundant before large bumps. Such talking coal, however, may not be a reliable indicator because the normal background of such noises is extremely variable owing to changing stress conditions in the coal and on the props; hence, a high amount of "talking" at one place may not foretell a bump, whereas much less "talking" at another place might indicate that one is about to occur.

Bumps in the Sunnyside district range in size from very small to very large. Very small bumps are manifested as small ticking noises in the coal. When we disturbed the outer surface (mine rib) slightly, during close geologic examinations of the constituents and structures of the coal, we commonly initiated many of these very small bumps. Very large bumps have damaged or destroyed $300 \mathrm{~m}(1,000 \mathrm{ft})$ or more of mine openings, or of several adjacent openings, throwing rock and coal laterally into the openings (frontispiece), destroying roof supports, collapsing roofs, and heaving floors upward into the openings. Results of the large bumps commonly are spectacular (figs. 3, 4), but many cause deaths or serious injury and entail much expense for mining companies to repair the damage. Loss of production time while cleaning up and repairing the mine ranges from a few days' to a few weeks' working time for a crew or several crews of miners; it is an additional large expense. The following examples illustrate some violent bumps and briefly describe the methods of failure. 


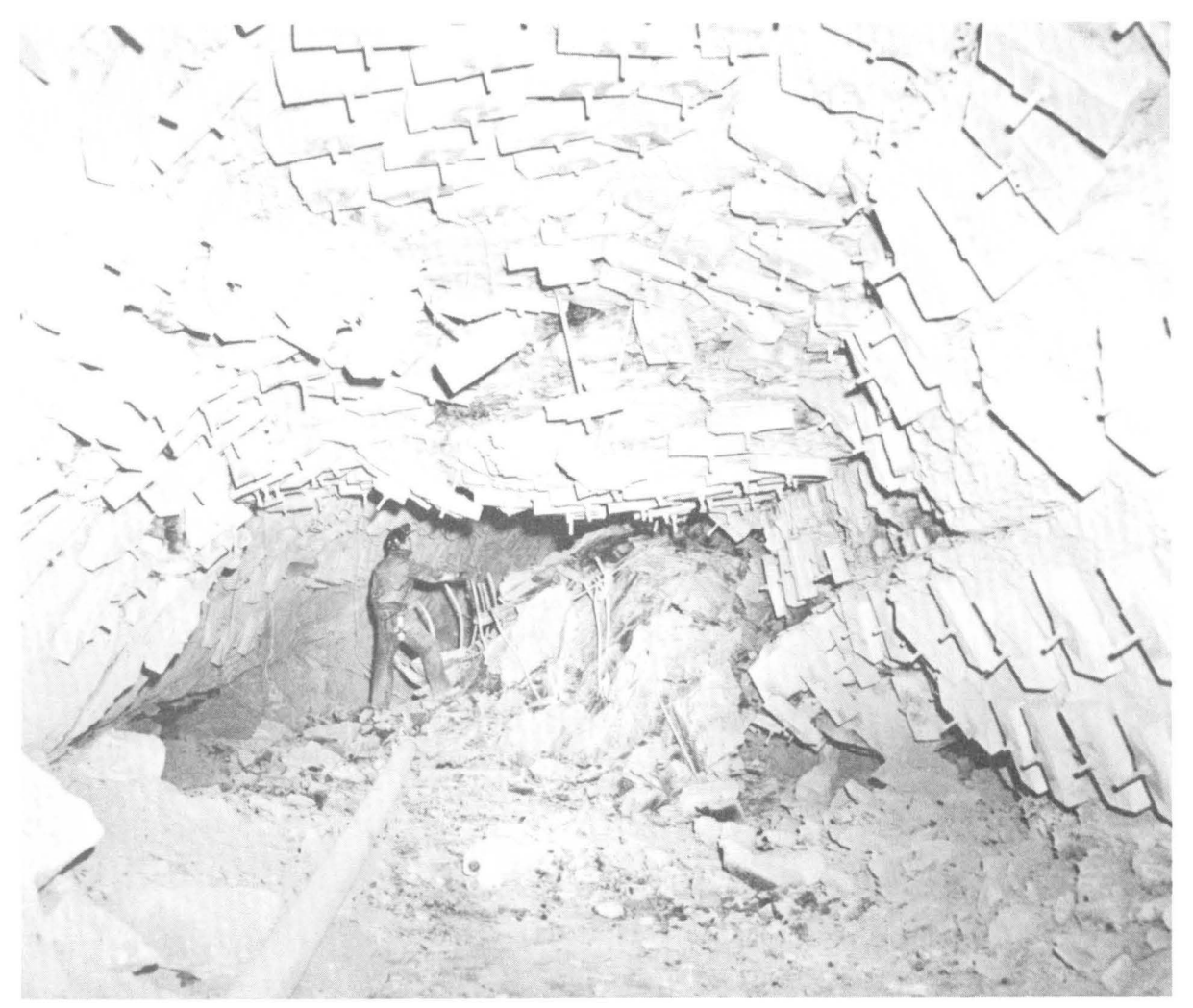

FIguRE 4.-View down right-side manway, Sunnyside No. 1 Mine, Utah, showing mass of curving rock slabs thrown laterally from roof near upper right part of picture. Sides of opening are curved shear fracture surfaces, formed during caving of the roof. Floor in foreground is rubble from the caving. Roof bolts $2.5 \mathrm{~cm}$ ( 1 in.) in diameter near floor on left side of picture were rotated almost $90^{\circ}$. Rock fragments on floor resulted from bump (burst) December 4, 1957. Photograph by J.C. Witt.

On December 4, 1957, a pillar adjacent to the main slopes in the Sunnyside No. 1 Mine (pl. 1), located between the right-side manway and an air return, bumped with extreme violence (Peperakis, 1958, p. 986) for a distance of about $67 \mathrm{~m}(220 \mathrm{ft})$ along the rib of the pillar (frontispiece). The opening had caved previously, because of high lateral stresses in the roof (fig. 36). The caved material had been used for fill, and the opening had been regraded for ventilation. The part of the pillar that failed, therefore, was in roof strata a few feet above the coal bed. A mass of rock and coal was thrown from the side of the pillar, apparently along a curving shear surface that extended outward into the roof (figs. 3, 4). Bent roof bolts and attitudes of bedding planes in the rock mass indicated that the mass was rotated about $90^{\circ}$ during the bump (frontispiece; fig. 4).

In September 1958, in the Sunnyside No. 2 Mine, a crew of miners accompanied by the mine superintendent was operating a cutting machine in the right (southeast) side of the mine, collecting large block samples for a group of geologists and engineers who were observing the work and selecting sample sites. The room was active, coal and timbers were "talking," and several small reports were heard as small pieces of coal were ejected from the face and ribs before cutting began. The face was undercut and one of the selected samples was being removed by cutting vertical slots in the face when active bumping began at the upper part of the face. A loud report occurred, at which time the mine superintendent, standing at the right side of the cutting machine directing the operator, instinctively jumped to the rear. A block of coal estimated to weigh about 1 ton, which was ejected from the upper right corner of the face, landed where the superintendent had been standing.

The main slope and the left-side manway of Sunnyside No. 1 Mine were damaged by a bump October 10 , 1958 , that affected an area about $230 \mathrm{~m}$ (750 ft) long between the 5 th left and 7 th left haulage entries, with the area extending about $150 \mathrm{~m}$ (a few hundred feet) northwestward. The greatest damage resulting from the bump, consisting mainly of loose coal thrown out from ribs (fig. 5) and new curved shear surfaces in rib 


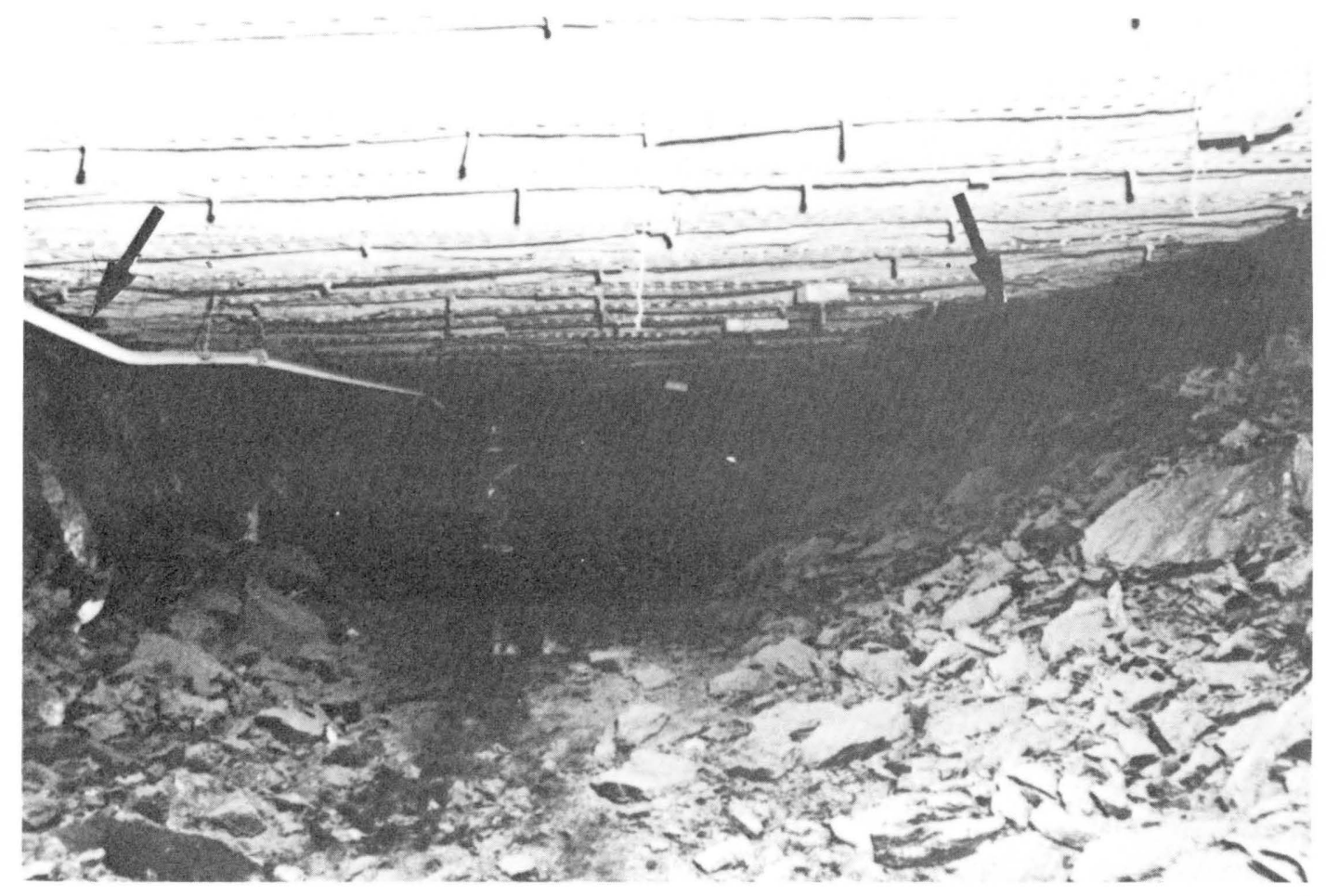

FIgURE 5.-View downslope (downdip) of loose coal thrown from ribs during a bump in left-side manway between 6th left and 7th left entries, Sunnyside No. 1 Mine, Utah, on October 10, 1958. Bump affected a large area from 5th left to 7th left entries. Margins of light area of roof (arrows) indicate position of coal rib before bump; light area is result of rock (limestone) dust applied to prevent coal dust explosions. Most loose coal is adjacent to right rib. Photograph by J.C. Witt.

coal, was near the slope and manway. Right-side (southeast) ribs of slope openings and diagonal crosscuts were damaged more than were left-side (northwest) ribs of the same openings. Damage to the openings from the bump diminished with increasing distance along the left entries, away from the slope and manway. Near the updip side of the bump area, damage was greater on the updip sides of the entries than it was on the downdip sides, but near the downdip side of the damaged area, the damage was greater on the downdip sides of entries than on the updip sides.

Another type of deformation during bumps was described to us by D.J. Varnes (oral commun., 1959) and J.T. Taylor (oral commun., 1960), although we observed no failures of this type. Varnes and Taylor observed a bump that was artificially triggered by injecting water at $4137 \mathrm{kPa}(600 \mathrm{psi})^{3}$ into a large pillar in the right side of Sunnyside No. 2 Mine in May 1958. The pillar failed violently, producing a shock that was heard and felt over a large area in the mine. Subsequent examination of the bump site indicated that the outer portion of the pillar was highly

\footnotetext{
"Pounds per square inch" as commonly used in mining engineering represents pound-force per square inch $\left(\mathrm{lbf} / \mathrm{in}^{2}\right)$.
}

fractured, with much loose coal thrown into the mine workings. The roof rock above the coal was intact, but the upper surface of the pillar was separated from the roof far enough so that a man could crawl into the opening (J.T. Taylor, oral commun., 1960). The height of the opening gradually lessened with increasing distance into the pillar, but probably extended as much

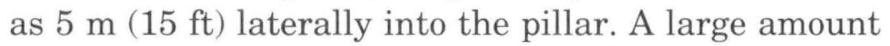
of brown coal dust was produced by the bump. Bumps that were equivalent to this one in energy and destruction were common in the Sunnyside No. 2 Mine (though most were not caused by water injection); however, such high energy and destructive bumps are rare in the Sunnyside No. 1 where most of our work was done. Both the geology and the mining practices were too complicated in the Sunnyside No. 2 Mine to yield useful information in the early phases of our work, and it was also considered to be too hazardous a place for us to begin our mapping.

An unusual type of failure resulted from a bump in the left-side manway of Sunnyside No. 1 Mine on a nonworking day in May 1960. The bump produced a tremor that was felt widely in and near the mine but was particularly noticeable to a fire patrolman who was traveling on an electric mine locomotive about 


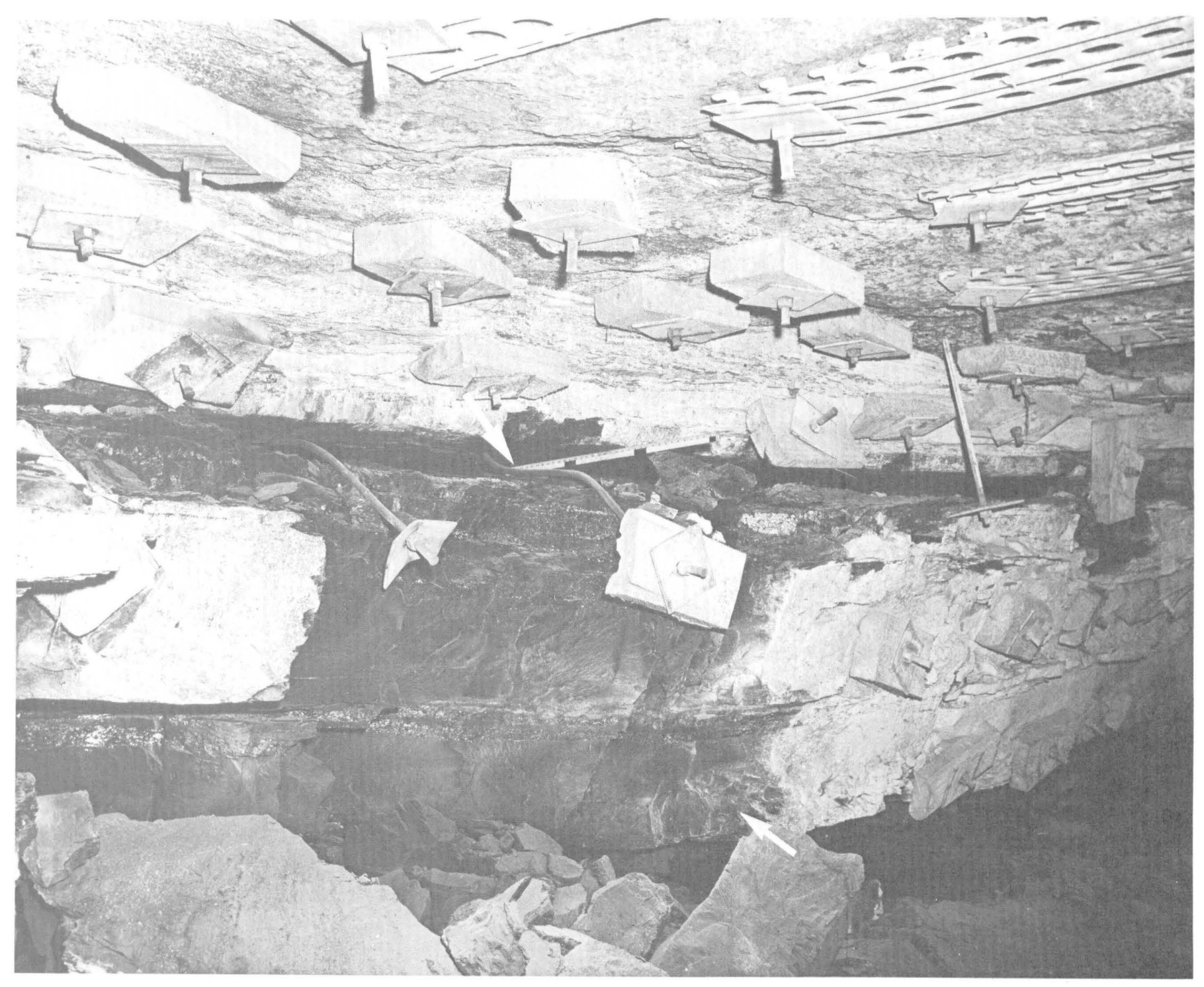

Figure 6.-View downslope of left rib, left-side manway, Sunnyside No. 1 Mine, Utah. Tongue of siltstone about $0.9 \mathrm{~m}$ ( $3 \mathrm{ft}$ ) thick was pushed out into manway about $0.76 \mathrm{~m}$ ( $30 \mathrm{in}$.) by bump in May 1960. Top and bottom of tongue are shear planes (arrows) that curve downward into the coal bed. Scale indicated by yardstick in center of picture, with foot-marks indicated by black tape. Photograph by J.C. Witt.

$805 \mathrm{~m}(0.5 \mathrm{mi})$ from the site of the bump. The locomotive, which weighs about 25 tons, bounced upward so that the wheels briefly left the track. The deformation in the mine produced by this bump was unusual in that a tongue of siltstone, about $0.8 \mathrm{~m}$ (30 in.) thick, was pushed outward into the manway as much as $0.9 \mathrm{~m}(3 \mathrm{ft})$. See figure 6 . The tongue was about $9 \mathrm{~m}(30 \mathrm{ft})$ long and was bounded above and below by curving shear planes that increased in dip as they passed into the underlying coal bed.

During 1964, a new mining area was opened in the Sunnyside No. 1 Mine, updip from the 11th left track entry (pl. 1), beginning at the barrier pillar beside the left-side bleeder slopes. In this area the Sunnyside coal bed was overlain by less than $1 \mathrm{~m}(3 \mathrm{ft})$ of brittle carbonaceous siltstone and $0.6-0.9 \mathrm{~m}(2-3 \mathrm{ft})$ of rider coal. Shear zones began to form in the roof (fig. 7) because the brittle siltstone broke into innumerable small chips when compressed (fig. 26); where landing mats were bolted to the roof across the shears, "baskets full of rocks" began to form (Osterwald and Dunrud, 1965, p. 173). Rooms were driven up the dip of the coal bed from the entry; when a few rooms were opened, pillars remaining between the active rooms and the barrier pillar were removed so that the roof could collapse and relieve excessive stress (abutment stress) on the pillars beside the active room. The carbonaceous siltstone and the rider coal were overlain by a massive siltstone (pl. 2) that did not collapse as the pillars were removed (fig. 7). Consequently, an unsupported roof span of a few hundred feet (less than $100 \mathrm{~m}$ ) was left between the barrier pillars and the 


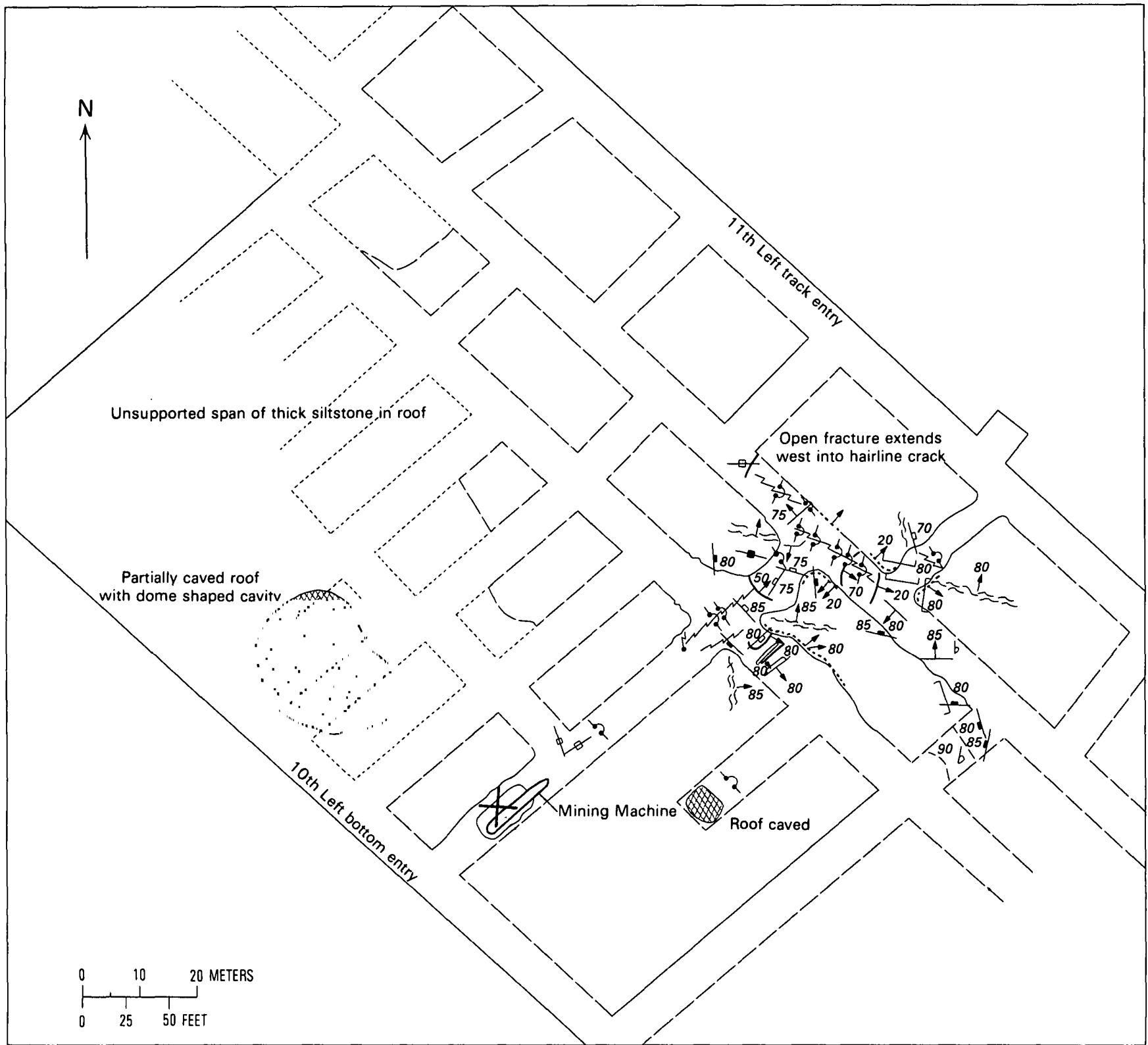

Base by H. Elkın, Kaiser Steel Corp.

Geology by F.W. Osterwald and C.R. Dunrud

\section{EXPLANATION}

Shear zone in roof with lateral shortening ("basket full of
rocks")

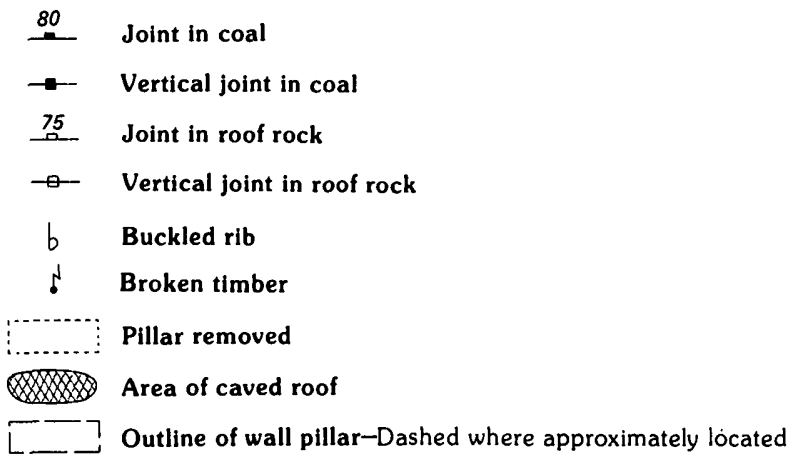

FIGURE 7.-Geologic map of 11th left track entry section, Sunnyside No. 1 Mine, Utah, showing deformational features related to violent bump of June 3, 1964. 
active workings. Mining had stopped temporarily in one of the rooms so that a 90-ton continuous mining machine could be serviced. A violent bump occurred, causing a compressive roof cave similar to the one shown in figures 35 and 36 and, probably because the additional load of the machine was transmitted by lateral stresses through the floor, causing upward forces (outside the area loaded by the machine) to increase the stresses on the ribs. Lateral components of force in the roof caused a mass of rock of about the same plan dimensions as the mining machine (fig. 7) to be forced downward, killing two miners. After the bump, the coal in the ribs continued to move along the newly formed, curved shear breaks, injuring four men several hours after the initial bump. The room bumped again several days later as the mining equipment was being removed, injuring three more men.

\section{DEFORMATIONAL FEATURES IN MINE OPENINGS}

Geologic features that we observed underground were easier to correlate with surface geology at the Sunnyside No. 1 than at the other mines because, in spite of extremely rough topography, a jeep trail gave access to most of the surface above the mine. The underground mapping gave an insight into the methods of failure of mine openings, which helped us in studying the mechanics by which bumps occur. Much of this mapping was unique because we mapped bent roof bolts, bent landing mats, and broken timbers as aids in determining sense and magnitude of extremely recent movements on geologic structures (Osterwald, 1962 b, p. 64-68). We also mapped small deformational features of both pre- and post-mine age in the coal and its associated rocks of the Sunnyside No. 1 Mine to study failure mechanisms of ribs, roofs, and floors. Structural features of both ages are shown on plate 1 . We later extended the underground mapping to areas of different geology and mining practice in the Sunnyside No. 2 and Columbia Mines (Osterwald and others, 1969) and in the Geneva Mine (Dunrud and Barnes, 1972; Dunrud, 1976) where we found some additional deformational features.

Underground mapping in the Sunnyside No. 1 Mine revealed that the coal deforms both by fracture and by creep; fractures are both pre- and post-mine in age, but all creep is post-mine in age. Coal in some places is deformed by fracture and creep apparently at the same time (fig. 8). Pre- and post-mine deformational features in all the mines generally could be distinguished by their relationships to such structural features as bent roof bolts, bent landing mats, and broken timbers.

\section{PRE-MINE DEFORMATIONAL FEATURES}

\section{SHATTER ZONES}

Shatter zones, which consist of elongated volumes of coal broken by numerous steeply dipping fractures, are the most abundant and easily observed structural features within the coal (pl. 1; figs. 9, 10). Most of the zones trend west and north to northwest, but locally they trend northeast and northwest (pl. 1). Individual fractures within each of these zones vary slightly in strike and dip, and most do not parallel exactly the attitude of the zone. The wide distribution and consistent attitudes of the west and north- to northwesttrending zones indicate that these zones are of premine age and are parts of the structural pattern of the district. These zones nearly parallel the trends of regional joints and faults (Osterwald and others, 1981, p. 45-52). In scattered localities, shatter zones were mapped at surface outcrops at orientations nearly parallel to cleavage planes in the coal (Osterwald, 1981, pl 2; Osterwald, 1962a; Osterwald and others, 1969). The pre-mine age of shatter zones also is indicated by the fact that most of them diverge at considerable angles from the orientations of mine openings. The less abundant northeast- and northwesttrending zones, however, are nearly parallel to many mine openings, and some may be of post-mine age.

Shatter zones are related both directly and indirectly to hazards from bumps. Because most zones are oriented at large angles to the common orientations of room-and-pillar mine openings, stress can concentrate in coal between the margins of shatter zones and mine faces and ribs, resulting in violent bumps (Osterwald and Brodsky, 1960): Slopes, with the exception of some diagonal slopes in the Columbia Mine, are oriented down the dip of the coal bed. Entries are laid out to the right and left of the slopes at an optimum haulage grade for the haulage motors in use at the time; thus, the orientations of the entries vary depending on the dip of the coal bed (pl. 1). Rooms normally are oriented parallel to the slopes. Thus, in most areas the mining plans do not result in a truly orthogonal pattern. This fact, together with major joint sets that commonly intersect at large angles (Osterwald and others, 1981, p. 45-57), causes most slopes, entries, and rooms to intersect shatter zones at large angles. Mine openings oriented at acute angles to shatter zones, however, result in much smaller stress concentrations and less violent bumps. Shatter zones also contribute indirectly to damage caused by bumps because the zones cause the coal to break into large splinters or irregular columns that fly outward or fall from ribs during bumps. The size of the splinters and columns is 


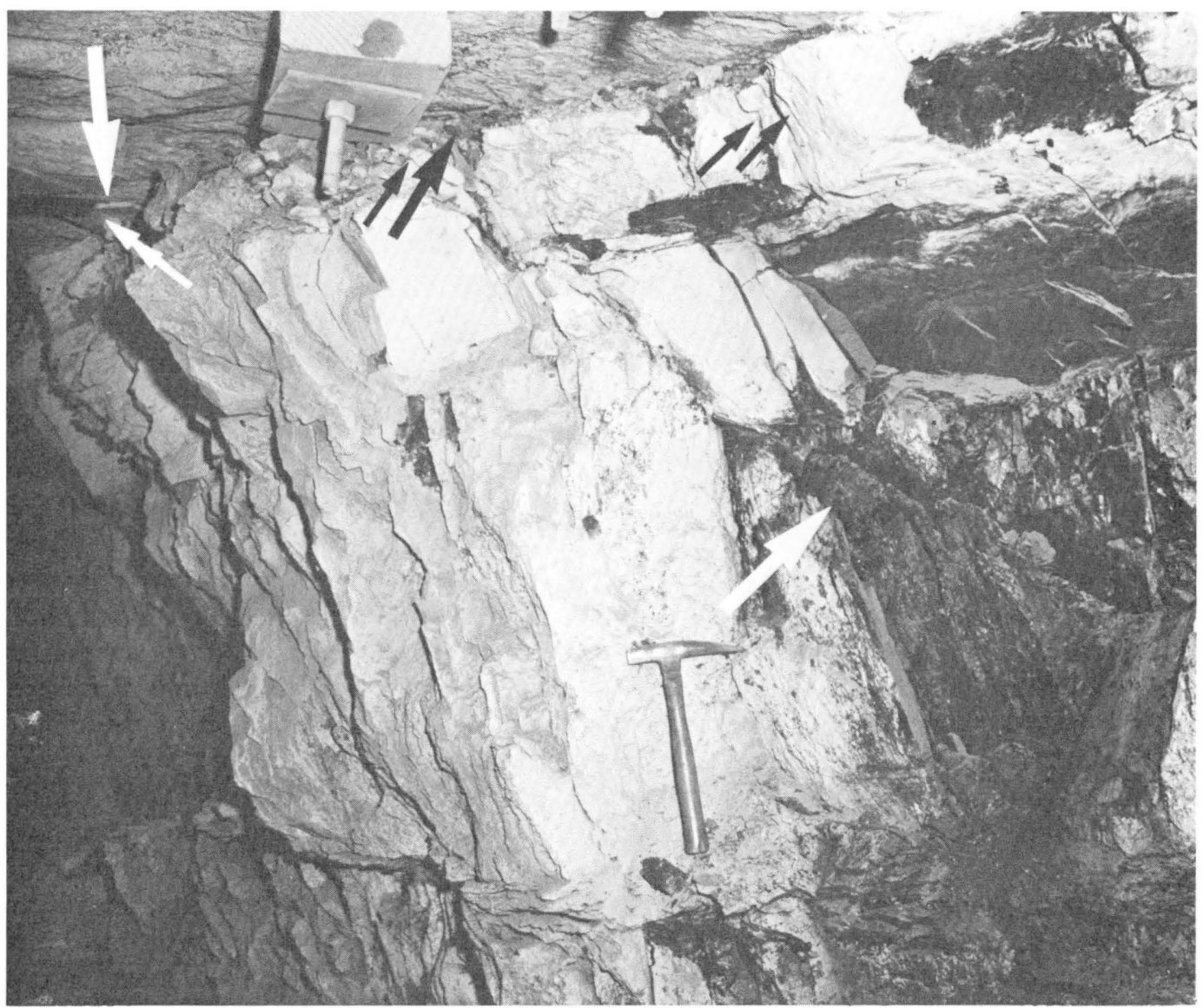

FIgURE 8.-Coal creeping into right-side manway at 1st right entry, Sunnyside No. 1 Mine, Utah, in 1958. Creep is accompanied by development of curving shear fractures behind rib, and one large fracture (long arrows) merges into the bedding plane between coal and roof rocks, which is becoming a plane of shear. Creeping coal is deforming and covering roof bolts (double arrow), and manway is becoming archshaped. Small shear cracks (short arrows) occur behind surface of coal. Light areas are coal dusted with powdered limestone. Photograph by J.C. Witt.

determined by the spacing of fractures within the zones, but some observed were as much as $0.6-0.9 \mathrm{~m}$ $(2-3 \mathrm{ft})$ wide.

\section{CLEAVAGE}

We mapped two types of cleavage in the mines, which are referred to here as "simple" and "spotted" cleavage. Simple cleavages are smooth planes that are most common within and parallel to the walls of shatter zones, although the cleavage planes do not parallel the individual uneven fractures making up the shatter zones. These simple cleavages actually are joint planes, which commonly are called cleat by miners. Spotted cleavages (Osterwald and others, 1981, p. 58) are small fracture planes, nearly parallel to each other, that commonly show smooth, nearly circular spots (fig. 10) making up what is known as eye coal (Stutzer, 1940, p. 249-253). We also mapped simple and spotted cleavages at coal outcrops in the district (Osterwald, 1961, 1962b; Osterwald and others, 1969). Cleavages could be useful as means to determine underground conditions in advance of mining because of their geometric relationships to shatter zones.

Several sets of simple cleavage cut the coal, although one steeply dipping set trending west predominates (pl. 1). These cleavages closely resemble fracture cleavage in metamorphic rocks. Individual simple cleavage planes are megascopically smooth and are 0.25$0.51 \mathrm{~cm}(0.1-0.2$ in.) apart. Simple cleavage is more common near the top of the coal bed, but the abundance varies generally with the proportion of megascopic vitrain lenses in the coal. Although simple cleavage is not present everywhere in the mines, we detected no systematic variation in its distribution.

Most spotted cleavage trends north to northwest and dips steeply in the Sunnyside No. 1 Mine (pl. 1), where it is nearly parallel to one of the regional joint sets 


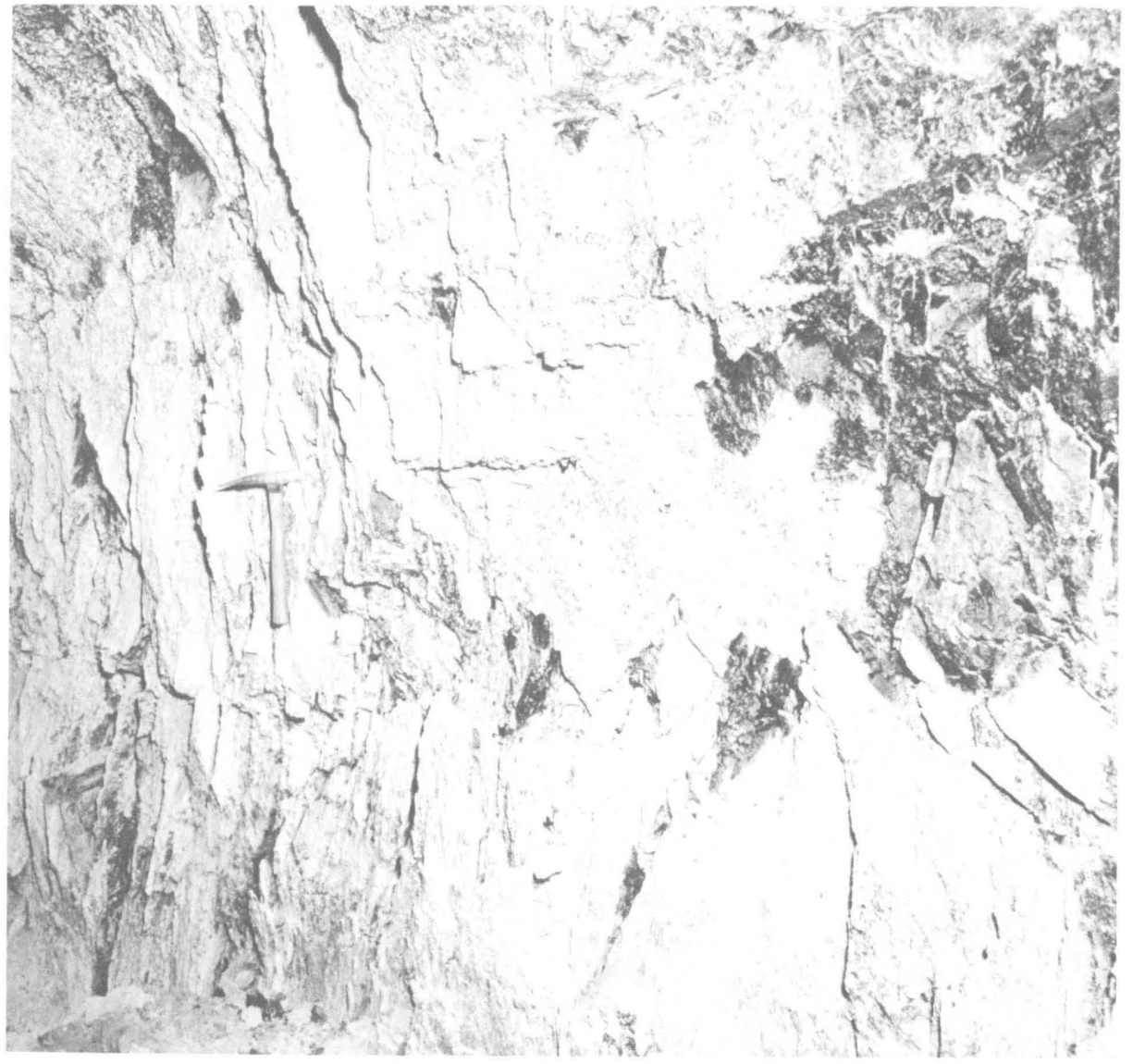

Figure 9.-Nearly vertical shatter zone in coal, along right rib of right-side air return above main parting, Sunnyside No. 1 Mine, Utah. Strike of zone is at a large angle (more than $60^{\circ}$ ) to the trend of the opening. Hammer handle is about $30.5 \mathrm{~cm}$ (1 ft) long. Coal is dusted with powdered limestone (light areas) Photograph by J.C. Witt.

Figure 10.-Closely spaced spotted cleavage planes ("eye coal") in main-slope manway, above main parting, Sunnyside No. 1 Mine, Utah. Rule $15.2 \mathrm{~cm}$ (6 in.) long indicates scale. Photograph by J.C. Witt.

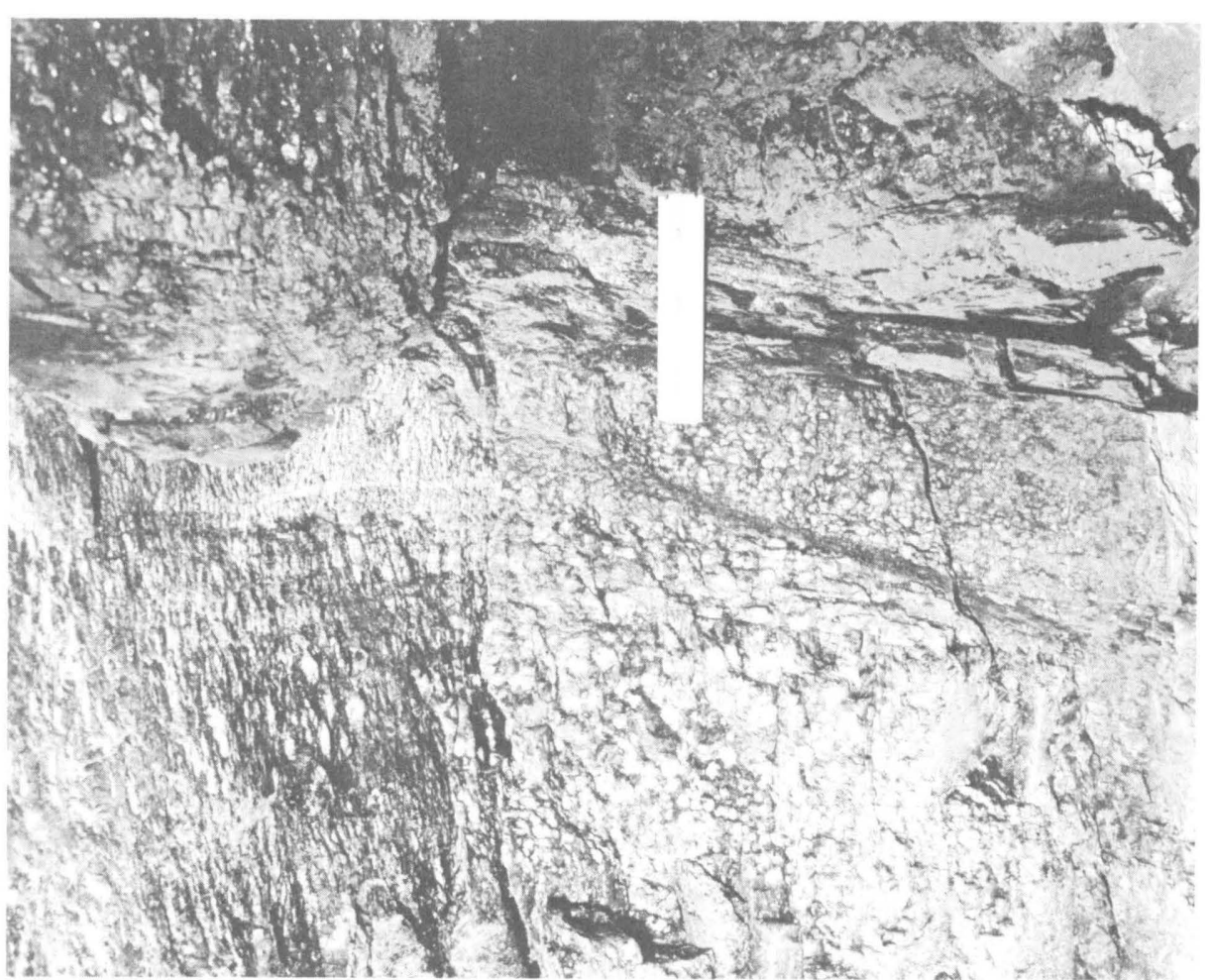




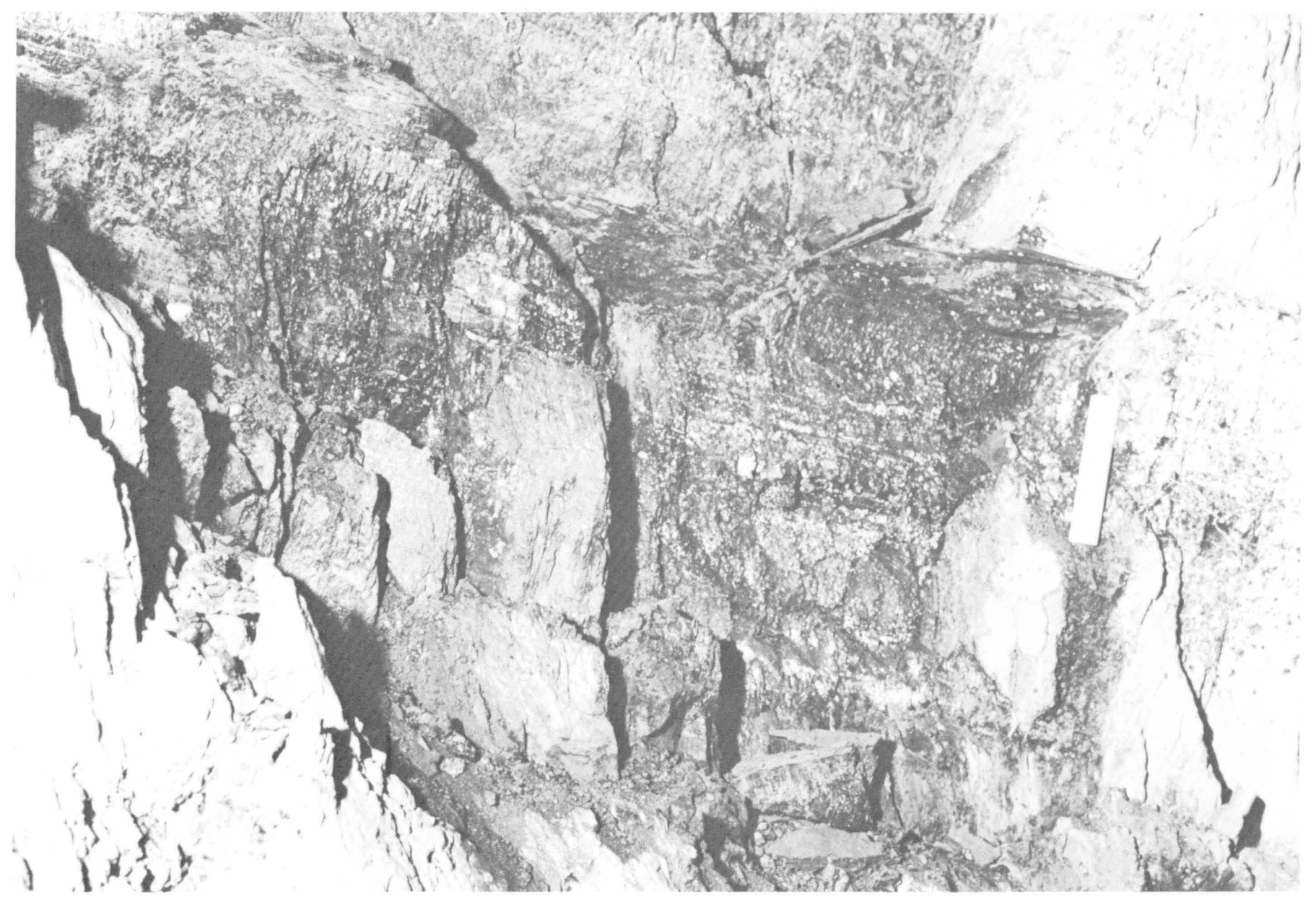

Figure11.-Spotted cleavage surfaces in upper part of coal bed in a pillar along the manway above the main parting, Sunnyside No. 1 Mine, Utah. Rows of small shining spots are along lenses of vitrain where they are cut by cleavage planes. Scale indicated by 15.2 -cm (6-in.) rule.

(Osterwald and others, 1981, p. 45-47). When they are not covered by rock dust, spotted cleavages (Osterwald and others, 1981, p. 58) commonly reflect light, as if they were a myriad of small mirrors (fig. 11). Most individual spots in spotted cleavage contain numerous small concentric ridges about parallel to the border of the spot. Where spotted cleavage planes are abundant, they are about $0.25-7.6 \mathrm{~cm}(0.1-3.0 \mathrm{in}$.$) apart. The$ average diameter of the spots in the Sunnyside No. 1 Mine is about $0.8 \mathrm{~cm}(0.3 \mathrm{in}$.$) , but they vary from$ 0.0127 to $5.08 \mathrm{~cm}$ (0.005 to $2.0 \mathrm{in}$.). Some of the spots in spotted cleavage planes are coated with thin films of white or light-yellow sulfates and are locally colored by iron oxide stains.

The origin of spotted cleavage at Sunnyside could not be determined, although it is probably related to the stresses that have acted upon the coal. A detailed study of "augen Kohle" (eye coal) in Westphalia, Germany, led Rischmüller (1955, p. 933) to investigate the formation of "augen" in the laboratory. He found that hammer blows on a block of pitch, resting on a solid foundation, produced fractures parallel to the direction of the blow. These fractures contained half of an "augen Struktur" whose midpoint was the point struck by the hammer. Nearly complete "augen Strukturen" were formed by compressing blocks of pitch in a press; these structures also formed in directions parallel to the direction of pressure. By analogy with these laboratory results, the steep dips of the Sunnyside spotted cleavage probably indicate that the "eye structures" were formed either by nearly vertical or by nearly horizontal stresses.

The "augen Strukturen" in Westphalia strike nearly at right angles to steeply dipping shear fractures (Schaufelflache) that cut the coal beds near the axes of major folds (Rischmüller, 1955, p. 935). Although no similar shear fractures exist at Sunnyside, the spotted cleavage planes do occur within the north- to 
northwest-trending set of a nearly orthogonal joint system in which slight movements may have occurred along the east- to east-northeast set. The spotted cleavage probably formed during Wisconsin time (Osterwald and others, 1981, p. 45) simultaneously with the regional joints. The vertical forces that produced the spotted cleavages and the joints probably were related to uplift of the San Rafael Swell (Osterwald and others, 1981, p. 43). The spotted cleavages may have formed along the set of joints trending north to northwest, as opposed to the set trending east to east-northeast, because of structural anisotropy established during coalification.

\section{PYRITE VEINS}

Although sulfide minerals are not widely distributed in the Sunnyside coal bed, small veins filled with claystone and pyrite are abundant locally in the upper part of the bed, just below the overlying rocks. The veins are most common in the right-side bleeder slope of the Sunnyside No. 1 Mine, the adjacent left-side bleeder of the Sunnyside No. 3 Mine (fig. 12), and the complex of mine openings updip from the main parting in No. 1 Mine (pl. 1; fig. 13). These veins occur in swarms, pinch out downward, and are only several centimeters (a few inches) deep and less than $0.64 \mathrm{~cm}$ $(0.25$ in.) wide; most dip steeply. Some interfaces between pyritiferous claystone and coal have horizontal slickensides. A few clay and pyrite veins in the roof of the left-side bleeder slope of No. 3 Mine contain slickensides that are nearly parallel to bedding, suggesting differential movement between coal and roof rocks. The distribution of the veins indicates that they are spatially related to the Sunnyside fault zone as defined by Osterwald and others (1981, p. 48-49), although they are not closely adjacent to it in the mine workings. The veins apparently are of pre-mining age. They fill fractures that may be the results of stresses accumulated near the Sunnyside fault zone in response to postfaulting tectonic movements. They have no apparent relationship to bumps.

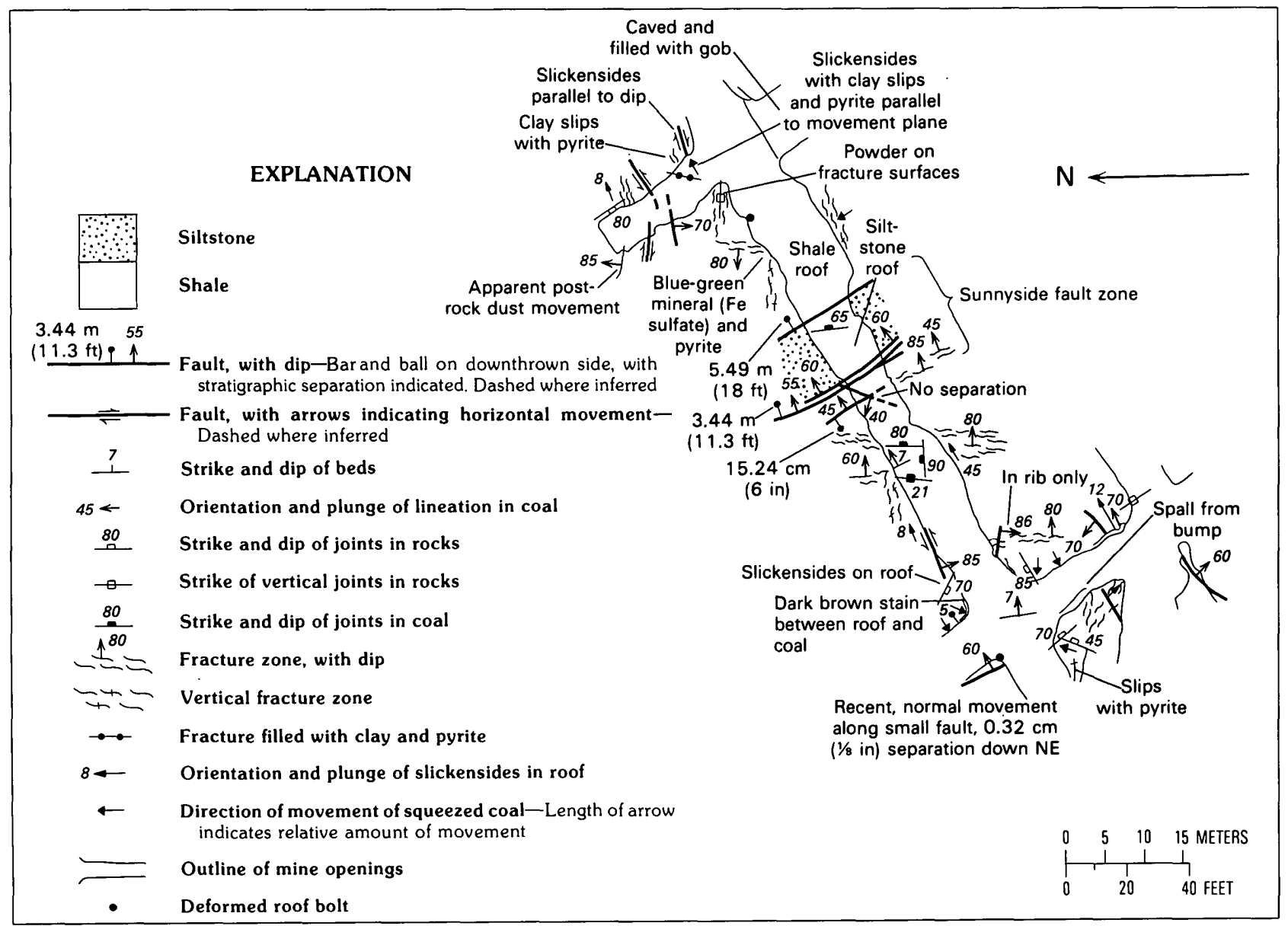

FIGURE 12.-Underground engineering geologic map, left-side bleeder slopes, Sunnyside No. 3 Mine, Carbon County, Utah. Plane mapped is roof. Scale $2.54 \mathrm{~cm}=12.192 \mathrm{~m}(1 \mathrm{in} .=40 \mathrm{ft}$ ). Geology by F.W. Osterwald and R.G. Eggleton, August 26, 1958. 


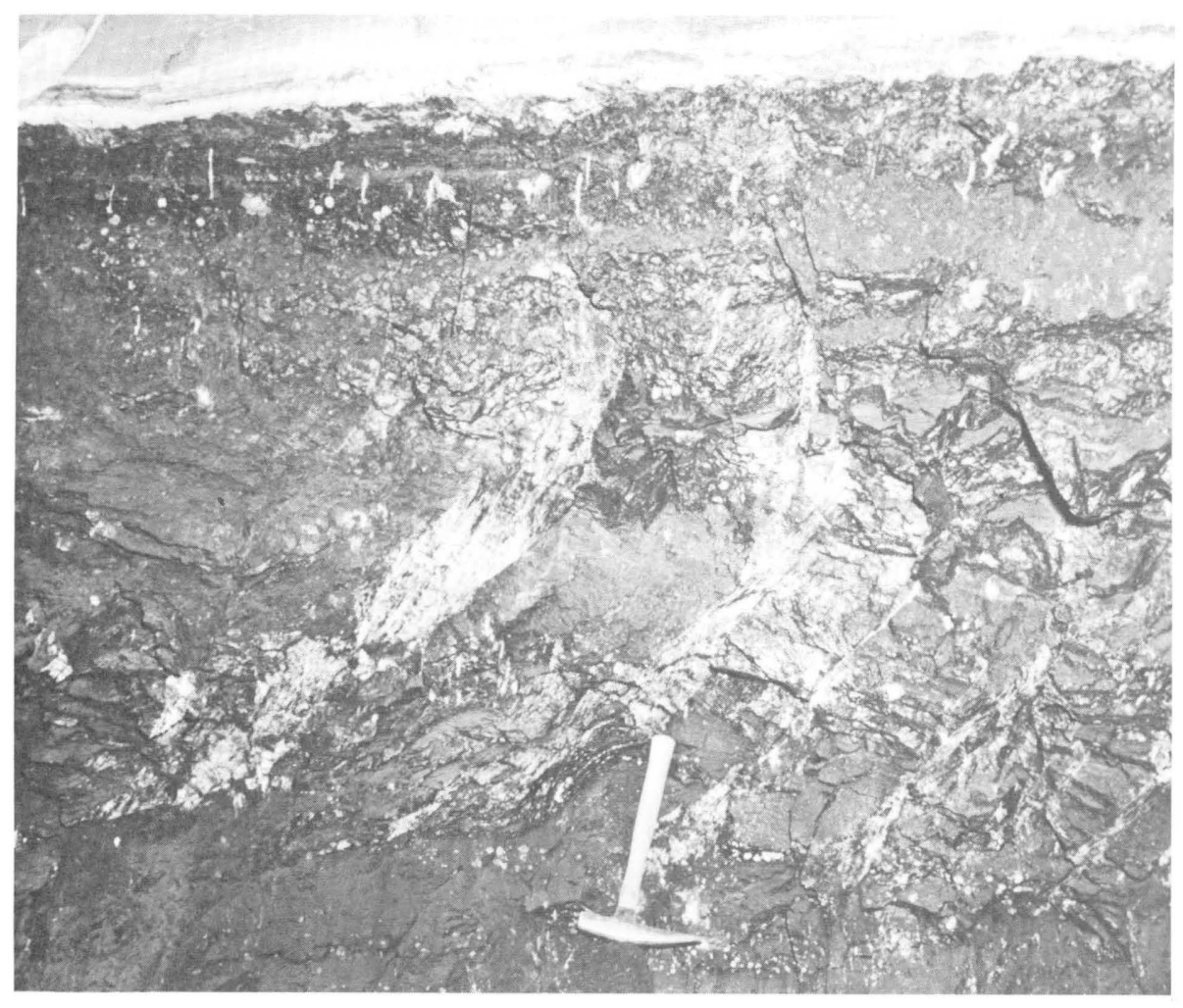

FiguRE 13.-Small veins filled with claystone and pyrite, near top of Sunnyside coal bed. Glistening curved fracture surfaces in central part of picture are smooth cylindrical fractures. A few spots on spotted cleavage planes are visible in the upper half of the picture. Irregular upper contact of coal bed is result of many large horizontal burrows (figs. 30,31 ) in laminated siltstone above the coal. Photograph taken in right-side aircourse above main parting, Sunnyside No. 1 Mine, Utah, by J.C. Witt.

\section{SMOOTH, CURVED FRACTURES}

Many smooth, curved fractures cut the coal in some places, but they are most abundant in a northwesttrending belt about $1220 \mathrm{~m}(4,000 \mathrm{ft})$ long and less than $200 \mathrm{~m}$ (600 ft) wide updip from the motor road and main parting of Sunnyside No. 1 Mine (pl. 1). Most of the fractures are parts of geometrically circular cylinders (fig. 14), but a few have flattened S-shaped or irregular vertical cross sections. In the north part of the Columbia Mine (pl. 3), surfaces with flattened $\mathrm{S}$-shaped or irregular cross sections are more abundant than fractures with truly cylindrical cross sections. All smooth fractures show slickensides; apparent movement in all instances indicates that the concave surfaces moved down the dip of the fractures with respect to the adjacent convex surfaces. Smooth fractures commonly occur in families of concentric or nearly parallel breaks; bedding surfaces in coal between some pairs of adjacent concentric fractures within individual families are rotated (fig. 14) as much as $65^{\circ}$ from their original dip. Rocks overlying the coal are not cut by the smooth fractures, although the beds in the lowermost $5 \mathrm{~cm}(2 \mathrm{in}$.) of roof rock are slightly bent above some of the fractures.

We infer the smooth fractures to be of pre-mine age because they were encountered by miners during initial development work. Most of them trend northwestward, parallel to the present trend of the Book Cliffs, and many are restricted in the Sunnyside No. 1 Mine to a narrow belt that is oriented diagonally to the trends of most mine openings (pl. 1). Because most of the fractures trend northwest (fig. 1; pl. 1) and because the steeply dipping slickensides on most of them indicate vertical relative movement, the fractures may have formed as a result of upward rebound of the underlying clayey rocks as the Book Cliffs were eroded northeastward to their present position (Osterwald and others, 1981, p. 43-45). Miners report that bumps are rare in areas of abundant smooth cylindrical fractures and that the coal is harder and blockier in such areas than it is elsewhere in the mines. This coal probably is harder to mine, either because the chemical composition changed as a result of molecular reconstitution during late deformation (as discussed later in this report on p. 68-71). The chemical changes 
may have increased the hardness, and hence the capacity of the coal to support stress. Alternatively, stress stored in the coal may have been released when the smooth cylindrical fractures were formed prior to mining so that, although the coal was physically harder than before, it did not yield violently when mined.

\section{CORRELATIONS BETWEEN BUMPS AND ORIENTATIONS OF PRE-MINE FRACTURES}

On the basis of underground mapping, the bumps and the directions of mine openings can be correlated with the orientations of pre-mine fractures in the coal, especially shatter zones (Osterwald and Brodsky, 1960), and with the orientations of faults (Watts, 1918; Peperakis, 1958). Miners reported that during mining for the raise partings on the motor road extension in Sunnyside No. 1 Mine, severe bumps (some of them powerful enough to overturn mine cars loaded with sand) occurred during the driving of headings that intersected shatter zones at large angles (pl. 1). These headings are the ones that nearly paralleled the direction of the motor road extension. Bumps that attended the driving of headings that were oriented more nearly parallel to the orientations of shatter zones and diagonal, or at small angles, to the direction of the motor road extension were frequent, but so small that they helped to make mining easy. A somewhat similar correlation between deformation of coal pillars and the orientations of their faces with respect to dominant cleat directions was described by Jeremic (1980, p. 30).

While an isolated mine opening (heading) is being driven, abnormally high compressive stresses are concentrated around it (fig. 15; Osterwald and Brodsky, 1960 , p. B145). These abnormal stresses are thought by some investigators to be inversely proportional both to the cube of the distance in front of the heading and to the square of the distance from the ribs of the opening (Isaacson, 1958, p. 119). The highest stress concentrations occur in a mass of coal whose long axis extends into the face at an angle of about $70^{\circ}$ with the direction of the heading (Osterwald and Brodsky,

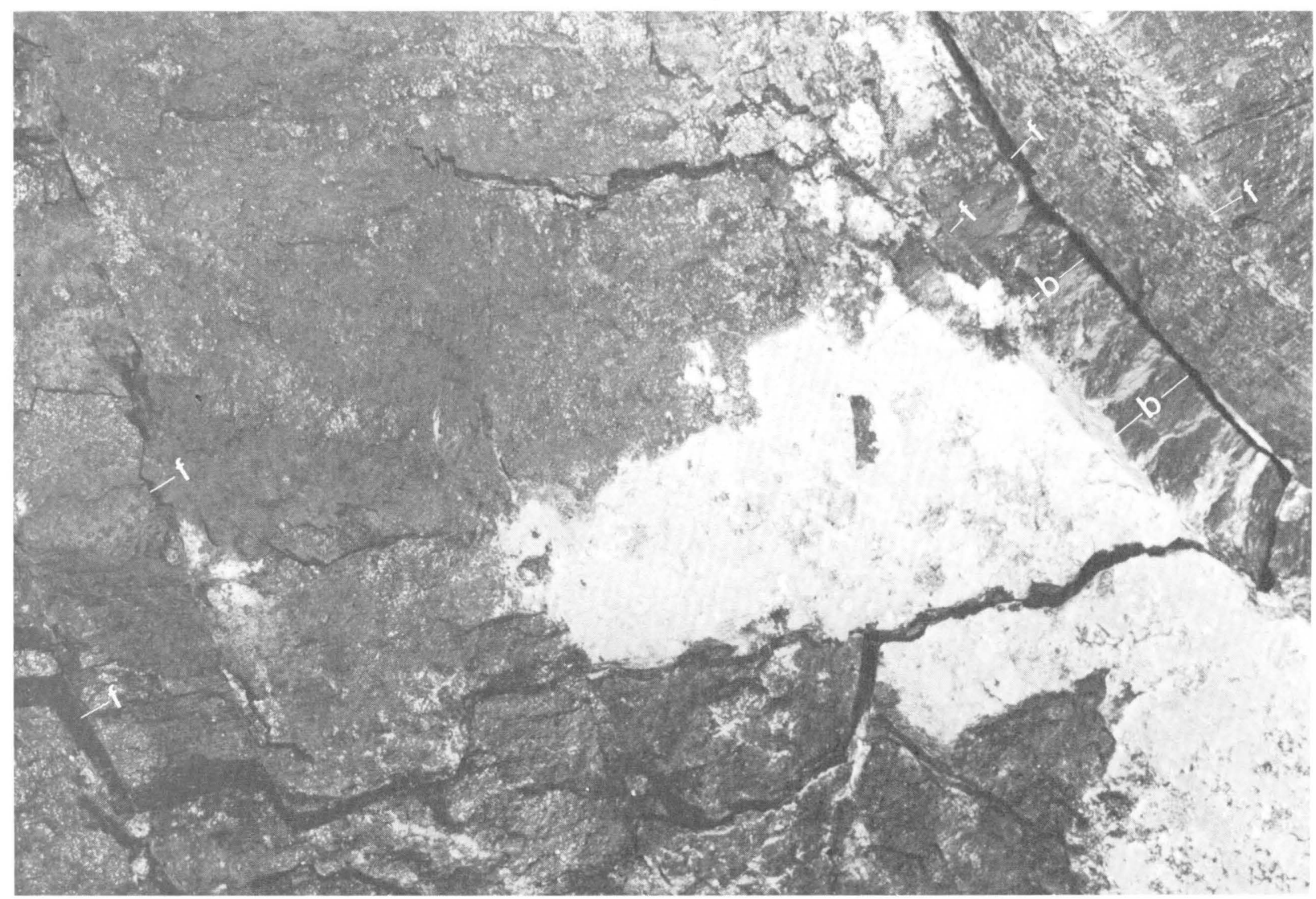

FIGURE 14.-Family of smooth curved fractures (f) in coal in incoming aircourse, Sunnyside No. 1 Mine, Utah, along main slopes above the main parting. Bedding (b) in "rind" between concentric fractures in upper right part of picture is rotated about $65^{\circ}$ from its original dip. Rind is about $7.5 \mathrm{~cm}$ (3 in.) thick. Light area is covered by limestone dust. Photograph by J.C. Witt. 


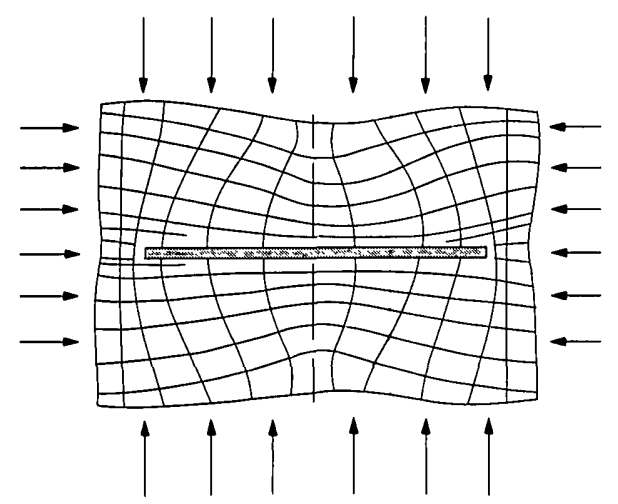

Figure 15. Hypothetical stress trajectories around a thin, wide, underground opening (patterned), showing transfer of stress from center of opening to the sides (ribs). Long arrows show direction and distribution of vertical compressive stress; short arrows show direction of lateral compressive stress. Modified from Avershin, 1955, figure 16.
1960, p. B145-B146; Isaacson, 1958, p. 78). The concentration of compressive stresses around an opening also results in a similar change of stress distribution in the vertical direction. The general concentrations and orientations of the stresses around an opening are shown in figure 15. The stress concentrations around an opening can, however, be markedly different when nearby mine openings or geologic structures also concentrate stresses. When a heading is near a fault or fracture, the volume of highly stressed coal becomes larger than when no fault is nearby (Isaacson, 1958, p. 78). As a heading nears a fault or fracture that is oriented at a large angle to the trend of the heading, stress is distributed uniformly over much of the face and is not concentrated in a small volume of coal (Osterwald and Brodsky, 1960, p. B146). A violent bump then may occur over much of the face as soon as the accumulated stress exceeds the strength of the coal. If, on the other hand, the heading approaches a fault or fracture that is oriented at a small angle to its trend, stress is concentrated behind a small area of the face and may cause only small bumps. If, however, the blocks of rock between faults and fractures are not supported by pillars and openings that are driven nearly parallel to the faults and fractures, mine roof falls can be more numerous. Therefore, an angle of $15^{\circ}$ to $30^{\circ}$ (equivalent to the approximate angle of internal friction of the material) between the directions of mine openings and major fracture sets may minimize both the incidence of violent bumps and the number of large roof falls.
After this correlation between bumps and the orientation of mine openings had been recognized, the company mining at Sunnyside carried out an experiment to test it. Prior to the experiment, rooms in the Sunnyside No. 1 Mine normally had been driven up the dip of the coal bed from entries that diverged at small angles from the strike of the bed (pl. 1). In the 8 th left entry section, however, a number of rooms were driven at orientations about $30^{\circ}$ southward from the dip direction (looking updip), so that they were within $15^{\circ}$ to $30^{\circ}$ of the major direction of pre-mine fracturing (pl. 1). This reorientation of the rooms produced rectangular-shaped pillars and yielded mining conditions very similar to those of the diagonal openings for the raise partings on the motor road extension; these rooms had numerous small bumps that aided mining. In addition, the roofs of those rooms were much easier to control properly. These results of the experiment apparently proved the correlation. Federal and State mine-safety inspectors, however, felt that the diagonal rooms subjected the mining-machine operators to an undue hazard because they were working on the right sides of the machines, adjacent to updip ribs. These inspectors requested that another system be tried, in which a large area of small square pillars was opened by driving rooms up the direction of dip and connecting them with crosscuts (vertically ruled pillars on pl. 1 (small square pillars)). These small pillars then were to be systematically removed. This system not only resulted in violent bumps, but the roofs in the large area of small square pillars could not be prevented from caving and much coal was lost because the pillars could not be removed. As a result, the company returned to its original system of narrow rectangular pillars oriented parallel to the dip of the coal bed (horizontally ruled pillars on pl. 1).

\section{POST-MINE DEFORMATIONAL FEATURES}

Structural features of post-mine age in the coal and associated rocks show a systematic relationship in distribution and trend to the outlines of pillars and to the trends of other mine openings. Post-mine features include fractures (termed "breaks" by miners) of various types as well as folds, such as roof synclines (miners' horsebacks) (figs. 12, 16) and floor anticlines (heaves) (fig. 17; pl. 1). We also mapped features formed by creep and plastic deformation of coal, such as bent landing mats, deformed roof bolts, broken crossbars (fig. 24), and bent track, as post-mine structures, all of these features (including bumps) are characteristic of squeeze. 


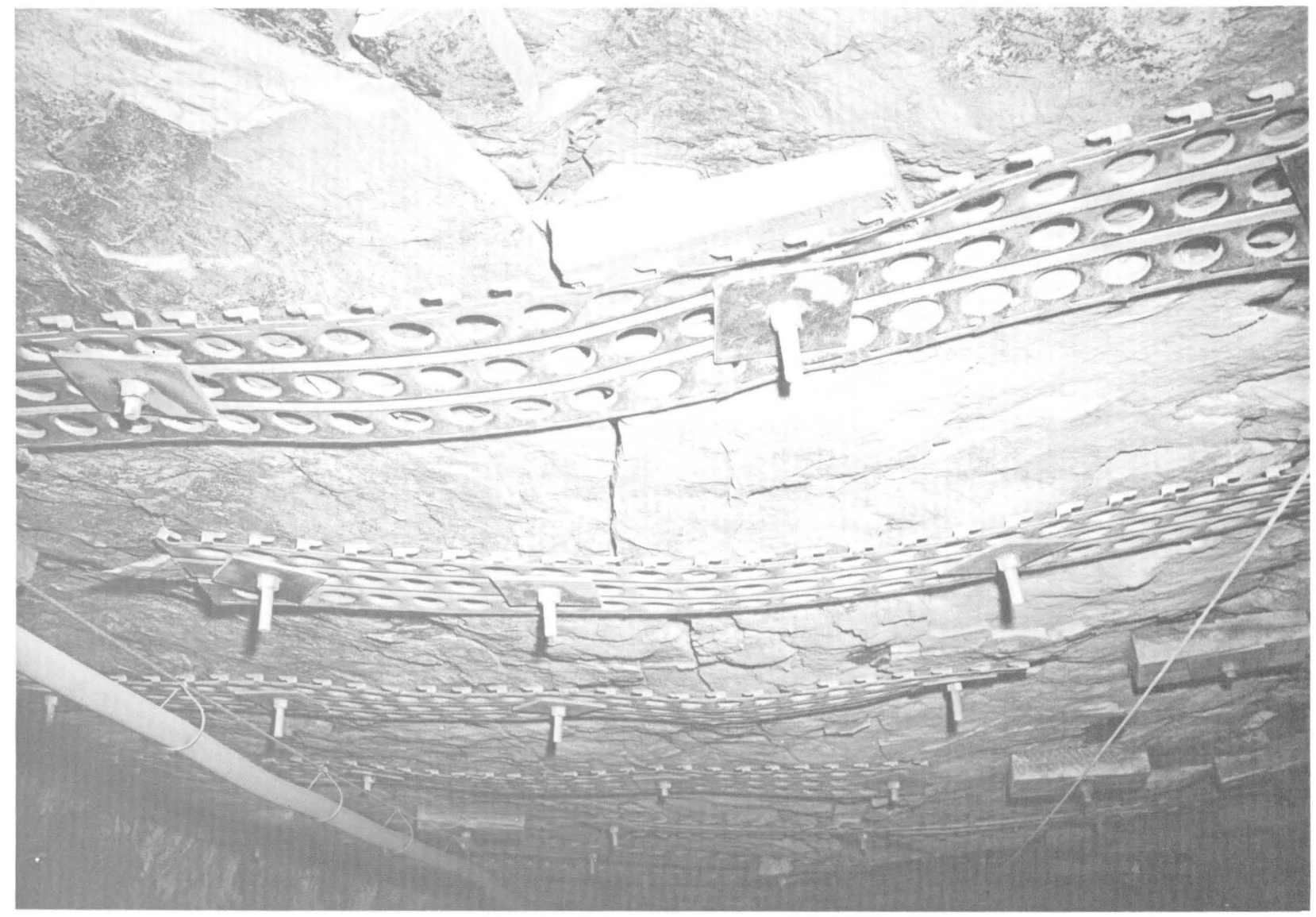

FIGURE 16.-Roof syncline (horseback) in carbonaceous siltstone overlying Sunnyside coal bed in the left-side aircourse (a slope opening) near the main parting, Sunnyside No. 1 Mine, Utah. Trough of syncline parallels opening direction, and longitudinal fractures are nearly parallel to the trough. Photograph also illustrates a common method of roof control, that of roof bolting through $10 \times 15 \times 31$-cm $(4 \times 6 \times 12$-in.) timber header blocks and $0.4-\mathrm{cm}(5 / 32$-in.) steel landing mats. Roof bolts are $2.5 \mathrm{~cm}(1 \mathrm{in}$.) in diameter. Photograph by J.C. Witt.

\section{SMOOTH PLANAR FRACTURES}

Smooth planar fractures dipping between $45^{\circ}$ and $90^{\circ}$ and striking generally northwest about parallel to the Sunnyside fault zone are abundant locally in the old right-side manway of the Sunnyside No. 1 Mine main slopes. A few such fractures diverge about $30^{\circ}$ from the strike of the Sunnyside fault zone and strike about north-northwest. Separation along smooth fractures generally is less than $15 \mathrm{~cm}$ (6 in.).

Recent movement along some of the smooth planar fractures was indicated by the absence of rock dust along fault planes that were examined in August 1958 in the Sunnyside No. 1 Mine main slope. These fractures presumably originated during a bump that occurred sometime between July 1 and 16, 1958. Much of the movement along these planes probably was horizontal, as indicated by a $0.6 \times 0.6 \mathrm{~m}(2 \times 2 \mathrm{ft})$ reinforced-concrete stringer in the main-slope haulage- way that was offset about $15 \mathrm{~cm}$ (6 in.) horizontally and $5 \mathrm{~cm}$ ( 2 in.) vertically during the bump.

Many smooth, steeply dipping fractures, spaced very closely, resulted from a bump during January 1957 (John Peperakis, Sunnyside mines, oral commun., 1958). Most of these fractures are within $100 \mathrm{~m}$ (a few hundred feet) of the Sunnyside fault zone (pl. 1), and they probably resulted from stress redistribution along the fault during the release of energy by the bump.

\section{BEDDING-PLANE SHEARS}

Bedding planes between coal beds and the overlying rocks commonly act as planes of shear during deformation of mine openings in the Sunnyside district (fig. 18). Such bedding-plane shears are particularly common beneath carbonaceous shale and siltstone roofs; the bottoms of some carbonaceous shale splits within the coal seam also behave as shear planes 


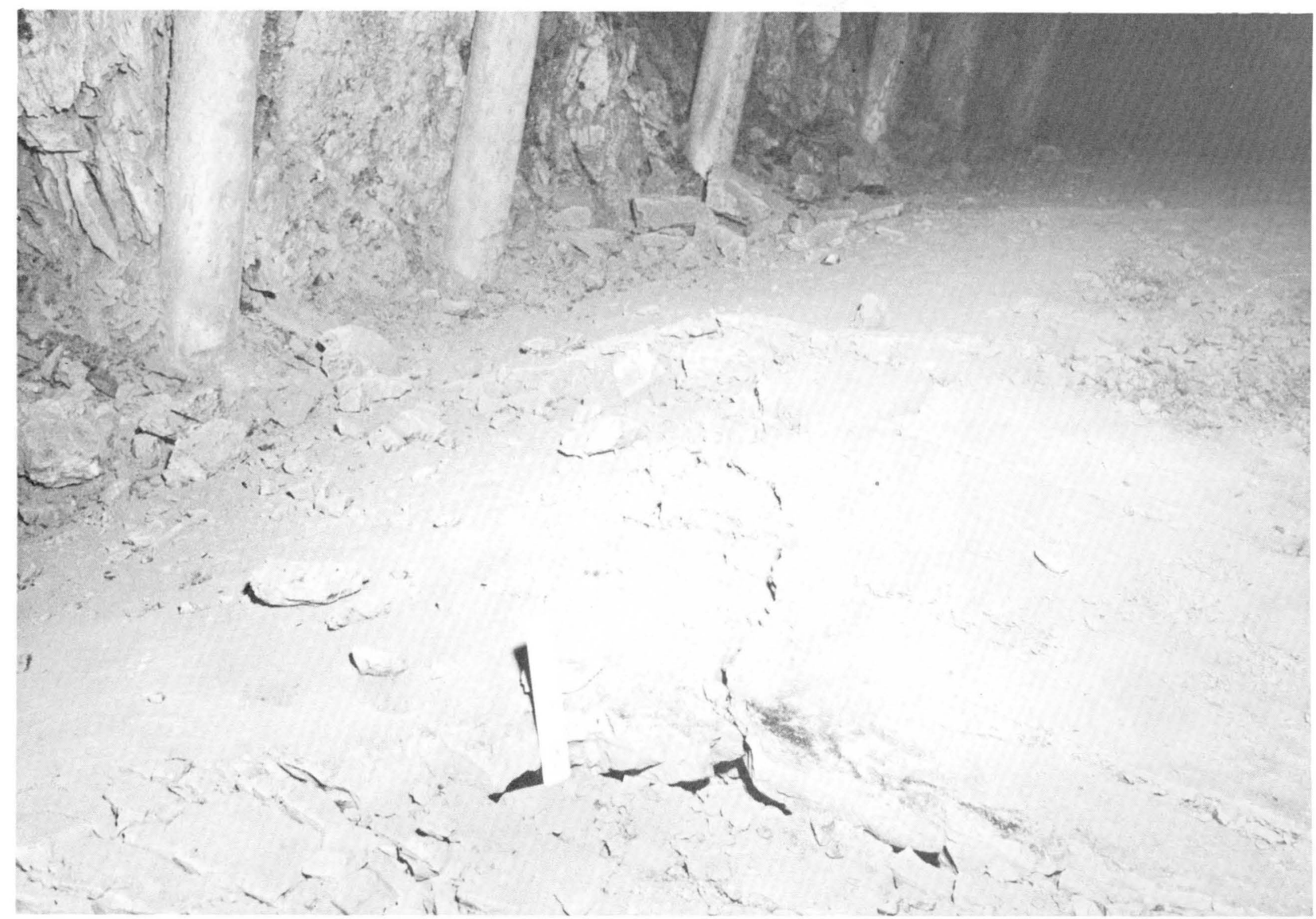

FIGURE 17.-Floor anticline (heave) in thin-bedded siltstone in the left-side airway near the main parting, Sunnyside No. 1 Mine, Utah. Crest of anticline, marked by irregular longitudinal fracture, trends obliquely to direction of mine opening. Cross faults with as much as $5 \mathrm{~cm}(2 \mathrm{in}$.) of displacement cut the crest. Scale indicated by 15 -cm (6-in.) rule. Photograph by J.C. Witt.

(Osterwald, 1962b, p. 65-66), as do some bedding planes within the coal bed (fig. 19) that separate coals which probably have slightly differing physical properties. The locations of these shears beneath shale and siltstone roofs in the Sunnyside No. 1 Mine can be inferred from plate 2; many are shown on plate 1.

Bedding-plane shears probably result from laterally directed stresses within the rib that cause the upper part of the coal to move slowly (creep) into the mine openings, so that the top of the coal becomes a shear plane (figs. 18, 20). Such movements locally cause coal to nearly enclose roof bolts and header blocks near the ribs. We observed horizontal movements of as much as $0.3 \mathrm{~m}(1 \mathrm{ft})$ in the main slopes of the Sunnyside No. 1 Mine. Gravity causes the coal near the ribs also to creep downward, forming gaps as much as $5 \mathrm{~cm}$ (2 in.) wide between the coal and the roof rocks. Overhanging coal ribs along the openings indicate movement on the shears, as do deformed roof bolts, landing mats, crossbars, and header blocks (Osterwald, 1961, fig. 274.1). The coal in the right (southeast) ribs of slopes commonly moves northwest relative to the roof rocks, so that right ribs have different profiles than left ribs; such movement probably is caused by sedimentary structures in the roof rocks whose orientations impede movement along bedding-plane shears in the opposite direction because of increased friction (Osterwald and Dunrud, 1965, p. 172; Maberry, 1968). Somewhat similar movements of coal into mine openings in western Canada presumably also resulted from laterally directed stresses, although many of the movement planes were originally shear planes of tectonic origin (Jeremic, 1980, p. 31-34).

\section{CURVED SHEAR FRACTURES}

Curved shear fractures, resembling cymoidal fractures (McKinstry, 1948, p. 315; Harrison and Wells, 1956 , p. 68-70; Osterwald, 1962 b, p. 66), are common in the mines in many parts of the Sunnyside district (pls. 1, 3; fig. 21) where coal slips with little frictional resistance beneath argillaceous roof rocks. Most curved shear fractures in the Sunnyside No. 1 Mine occur in the ribs; they are almost parallel to bedding near the 


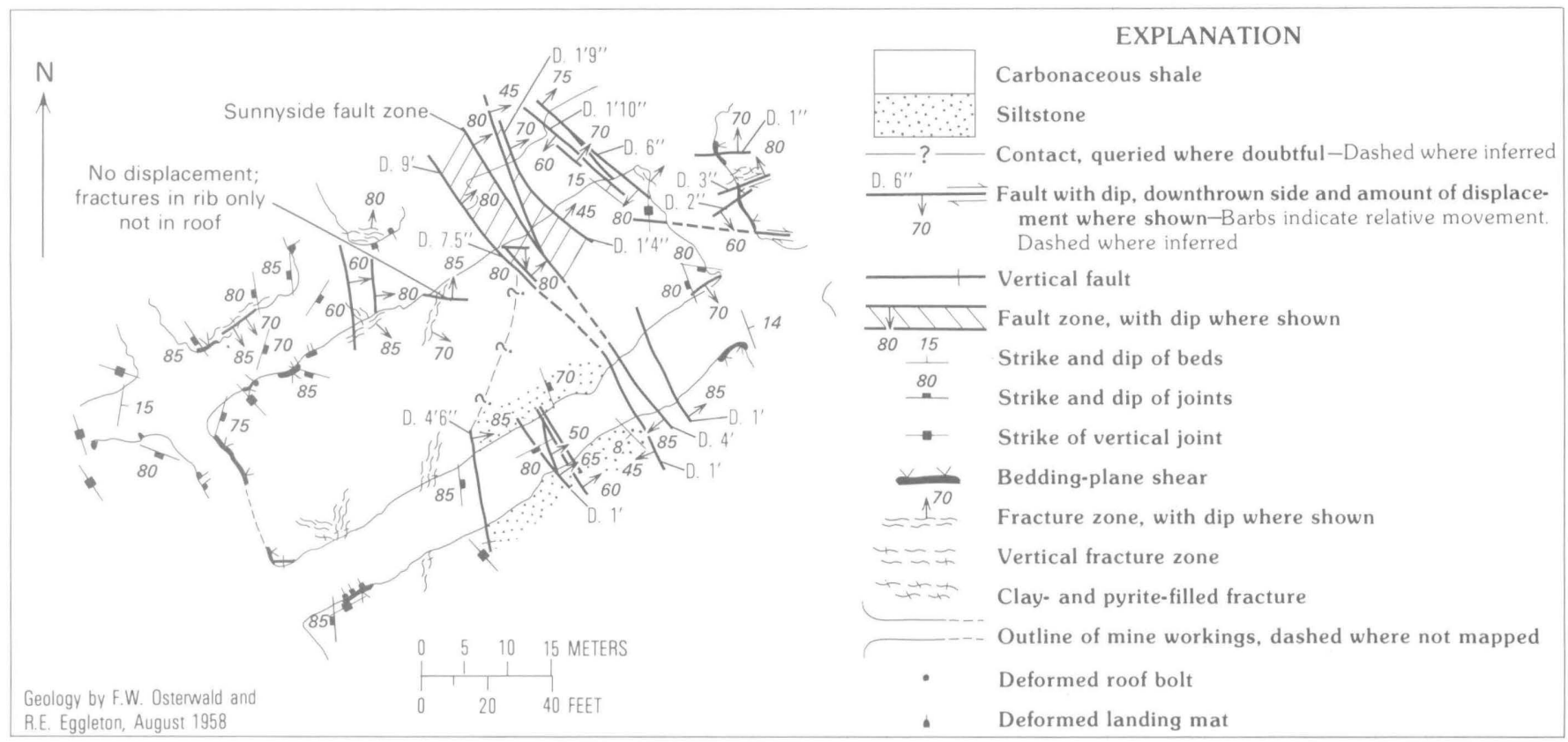

FIGURE 18,-Underground geologic map of the right-side bleeder slopes at Sunnyside fault zone, Sunnyside No. 1 Mine, Utah, showing bedding-plane shears. Plane mapped is roof.

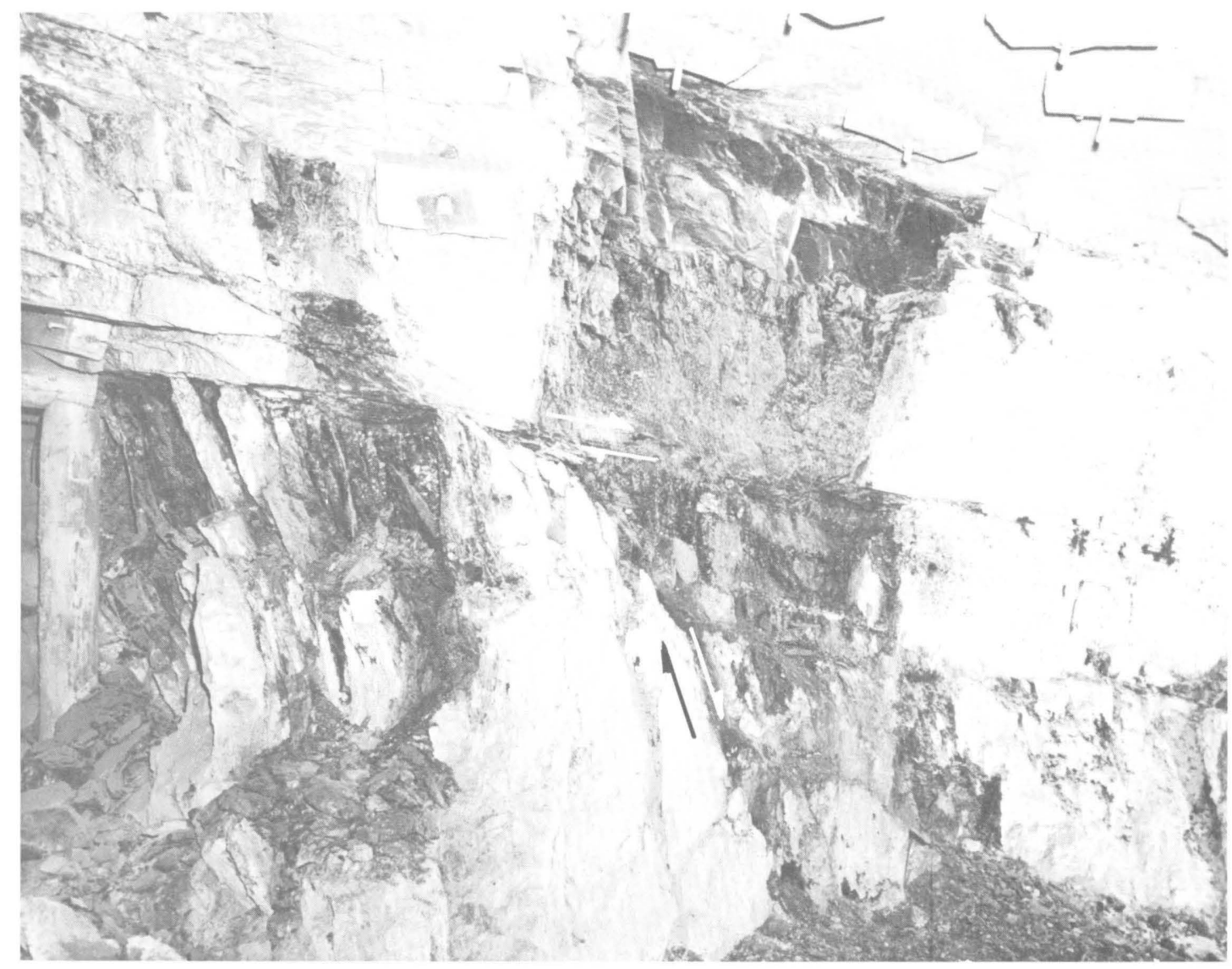

FIGURE 19.-Bedding-plane shear (post-mine failure) between coals of different properties (short arrows), probably because of different compositions. Long arrows indicate shear on curved shear fracture. Left rib of right-side manway at 1st right entry, Sunnyside No. 1 Mine, Utah. Light areas of coal are coated with powdered limestone. Photograph by J.C. Witt. 


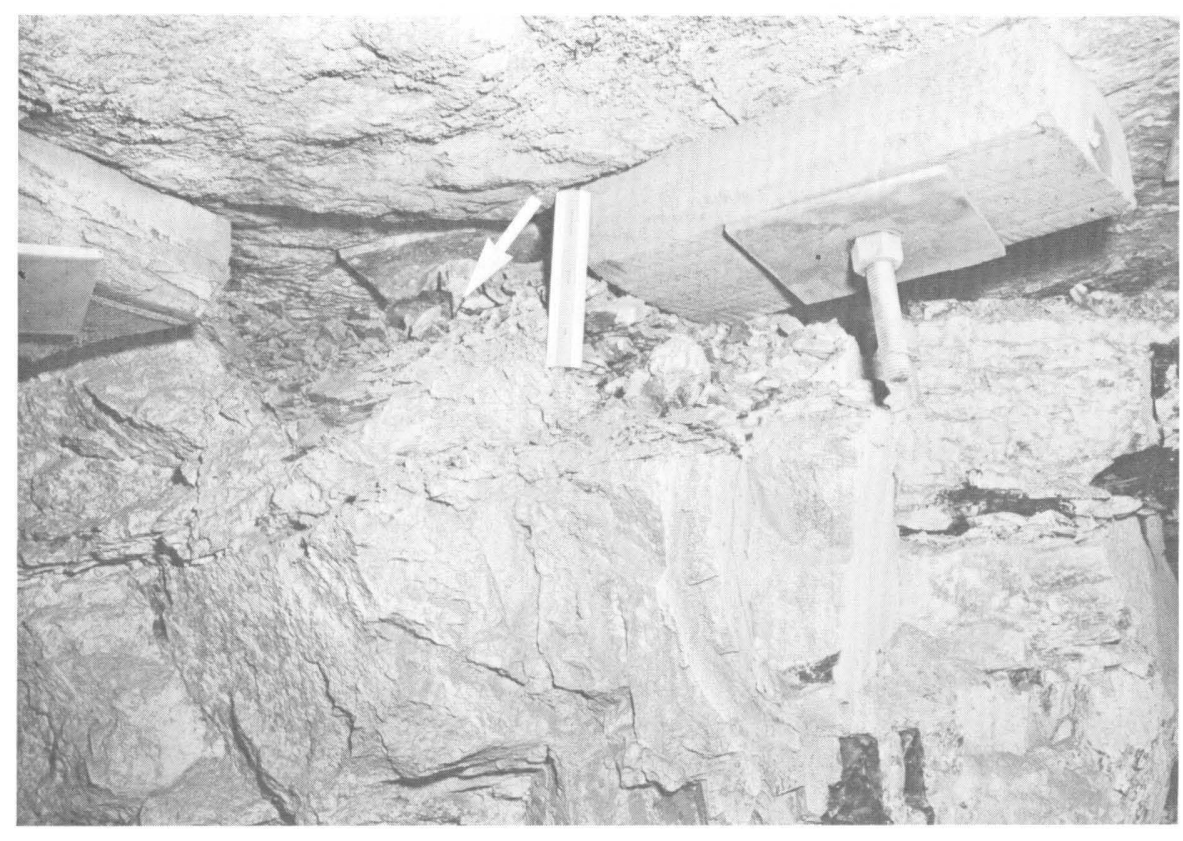

FIGURE 20.- - Rib coal at a pillar corner moving by creep into right-side manway at 1st right entry, Sunnyside No. 1 Mine, Utah. Coal is deforming and covering roof bolt (arrow) to left of 15.2-cm (6-in.) scale. Light-colored coal is covered by limestone dust. Photograph by J.C. Witt.

intersections of ribs and roofs, but the dips steepen markedly below the roofs, and the fractures dip as much as $60^{\circ}$ about $1 \mathrm{~m}(3 \mathrm{ft})$ below the roofs. Many were nearly vertical at mid-height of the ribs. From the roofs, many of the curved fractures can be traced about $1.4 \mathrm{~m}$ (4.5 ft) downward into the ribs; but, from bedding planes within the coal, some small ones extend downward only several centimeters (a few inches). Some small fractures steepen downward from one bedding plane in coal and flatten again as they approach another bedding plane several centimeters (a few inches) below. A few curved shear fractures pass entirely through thin coal pillars (fig. 22), but these dip less steeply than ones in the ribs of thick coal pillars.

Many curved shear fractures in the Columbia Mine dip steeply near the top of the coal and flatten downward, becoming parallel to bedding near the mine floor (pl. 3). Some fractures similar to those in the Columbia Mine occur in roof sandstones in the Sunnyside No. 1 Mine; these fractures probably formed during roof caving that was induced by lateral stresses in the roof (Osterwald and Dunrud, 1965, p. 171-172). In the Columbia Mine, near the left-side barrier pillars, curved shear fractures that steepen upward and downward occur together (pl. 3). Although the coal locally is deformed visco-elastically, we found no evidence that compressed coal pillars behave as compressed plastic cells in the sense of those described by Prandtl (1924), Nadai (1950), and Varnes (1962, p. B21-B23,

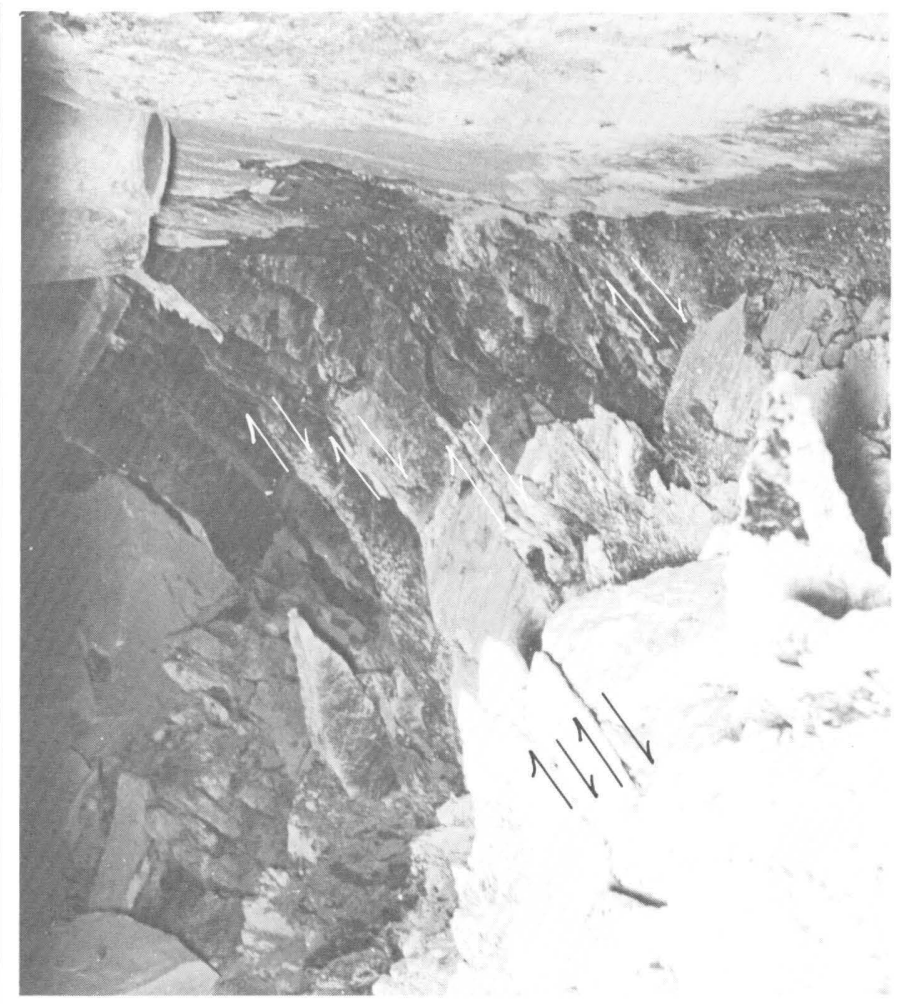

Figure 21.-Curved shear fractures in upper part of rib near bumpdamaged area, 3d north entry vicinity, Columbia Mine, Utah. Timber in upper left corner is about $20 \mathrm{~cm}$ (8 in.) in diameter. Arrows (shear couples) indicate relative movement along shear fractures. Light areas in coal are covered with limestone powder. 


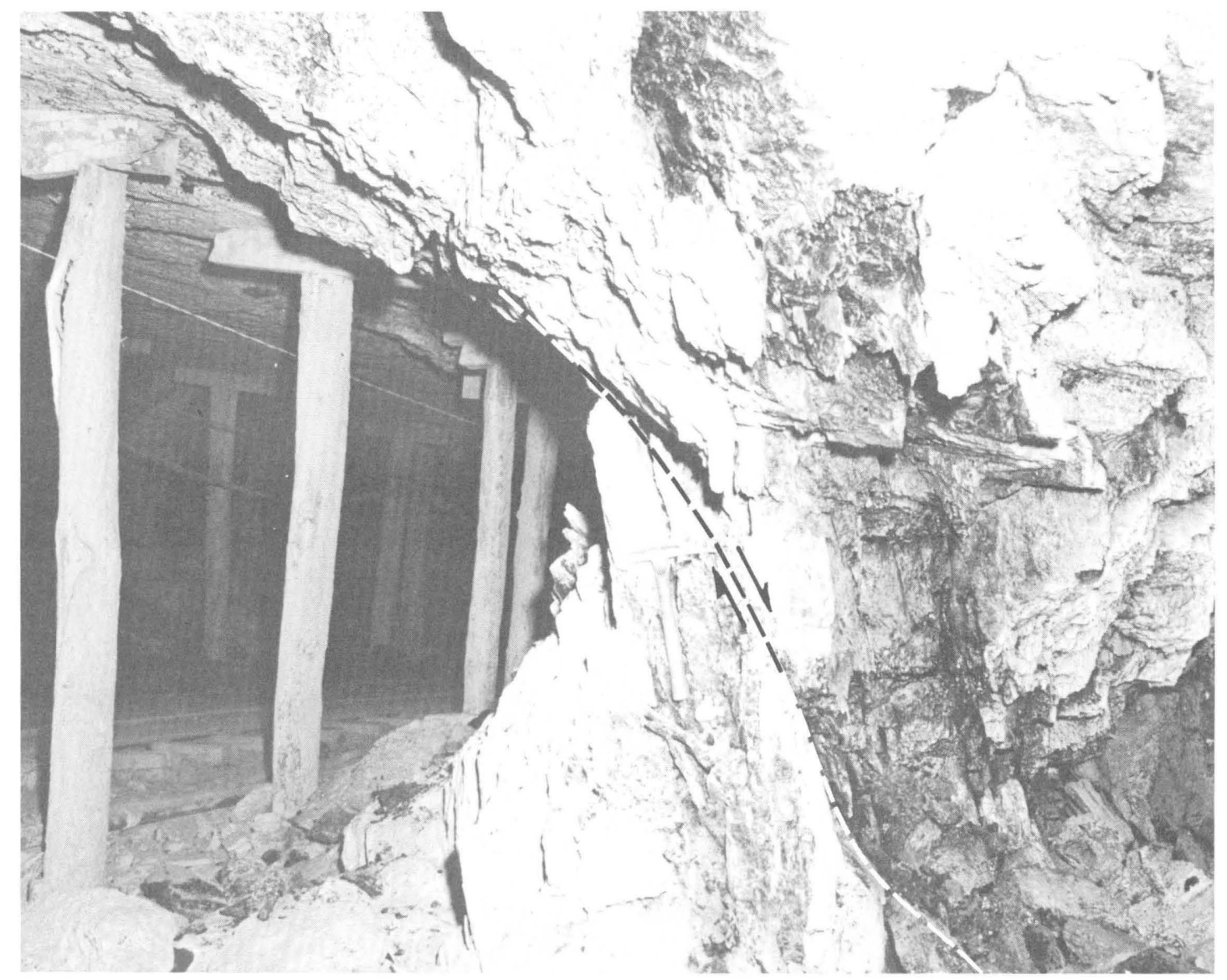

FigURE 22.-Curved shear fracture passing entirely through thin coal pillar, 5th left entry, Sunnyside No. 1 Mine, Utah. Arrows (shear couple) indicate relative movement along shear fracture. View is toward mining face at intersection of entry with diagonal crosscut. Hammer handle is about $30 \mathrm{~cm}(1 \mathrm{ft})$ long. Light-colored areas are covered with powdered limestone. Photograph by J.C. Witt.

B35-B39). If the coal pillars behaved as plastic strips compressed between two plates (roof and floor rocks), the slip lines (shear planes) within it should be cycloids (Prandtl, 1924). If, however, the plates (roof and floor) are not exactly parallel, the coal could be deformed plastically as a compressed wedge (Nadai, 1950, p. 543; Varnes, 1962, p. B36). Within such compressed wedges, the slip lines should be exponential curves (Kanizay, 1962, p. B10-B11). The curved shear fractures in the coal at Sunnyside, however, are neither cycloids nor exponential curves as drawn by Kanizay (1962, p. B11). Measurements of points along vertical planes through several curved shear fractures yield curves that approximate halves of divergent parabolas (fig. 23A).

Curved shear fractures in the mines at Sunnyside probably resulted from movement along differently oriented, but related, planes in the coal ribs and in roof and floor rocks. The shapes and modes of formation of the fractures resemble those of the cymoid-shaped fissure veins in the Freeland-Lamartine district, Colorado, described by Harrison and Wells (1956, p. 70). The long central parts of these curved fissure veins formed first, by slipping along steeply dipping axial planes of folds. This slipping was followed by movements along tension fractures located at each end of the central fractures and diverging at slight angles from the trends of the central fractures. The final, more tightly curved ends of the fissure veins were formed by movements along preexisting joints. The resulting fissure veins in plan view closely resemble the curved shear fractures at Sunnyside in vertical cross section (fig. 23A). The different parts of the Sunnyside curved shear fractures probably did not form in the same time sequence as parts of the Freeland-Lamartine fissure veins; nevertheless, a combination of events that resulted from high compressive stress, as shown in figure $23 B$, can be determined as follows: 


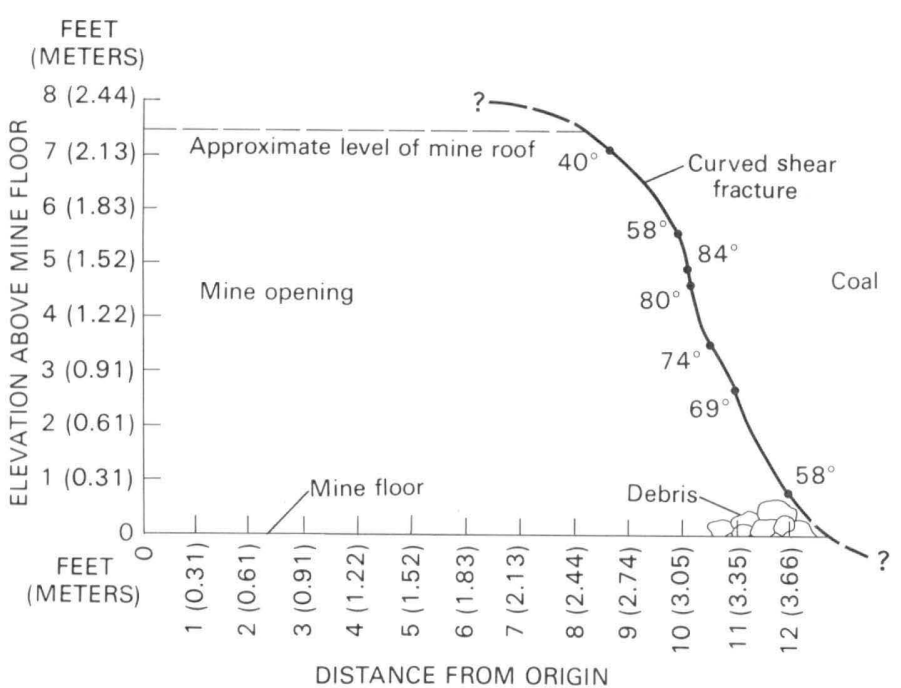

A, Vertical cross section through curved shear fracture, manway in main slopes above main parting. Points at which measurements were made are shown by solid circles; dip of fracture surface indicated in degrees.
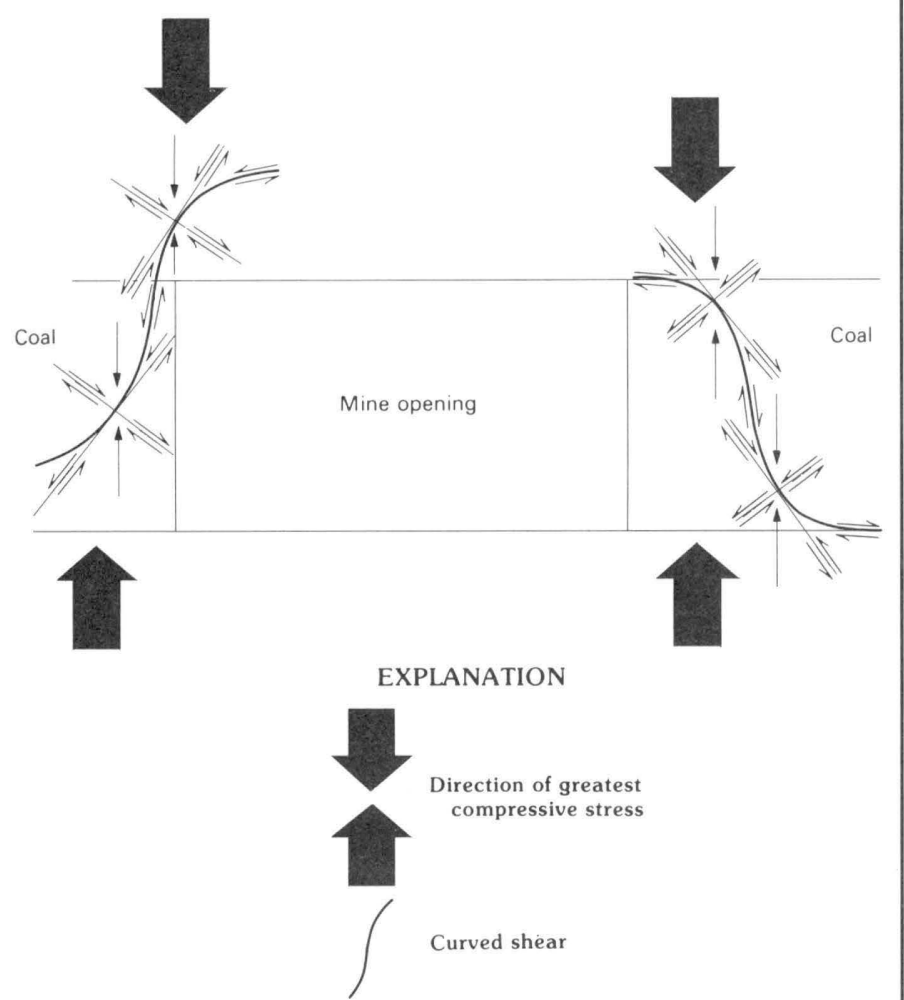

$B$, Diagrammatic sketch showing relation of markedly curved parts of curved shear fractures near mine openings to vertical compressive stress.

Figure 23.-CURVED SHEAR FRACTURES, SUNNYSIDE NO. 1 MINE, UTAH
1. After the mine opening is cut, the ribs fail along tension fractures that are parallel to the greatest compressive stress direction, which is vertical.

2. Slippage occurs along favored directions of conjugate shear breaks in and near the roof and floor (fig. 30). These favored directions dip away from the openings.

3. Coal slips along bedding planes at the top and bottom of the coal beds, or along other bedding planes within the coal or roof rocks.

\section{CREEP}

Slow nonelastic deformation (creep) of coal and some of its associated rocks has been common in local areas of the mines throughout the Sunnyside district (Osterwald, 1962b, p. 65). Close observation reveals that the slow, flowlike deformation commonly has been accompanied by the growth of small shear cracks parallel to the outward surfaces, but as much as $0.61 \mathrm{~m}$ ( $2 \mathrm{ft}$ ) behind them. Most creep occurs near the roof line of mine openings, which commonly coincides with the top of the coal bed. Planes bounding the upper surfaces of coal that has creeped commonly are bedding-plane shears, even where the top of the coal is in the rib and not actually at the roof line. Creep also occurs locally where highly carbonaceous shales are above or within the coal bed. Pillar corners are more subject to creep than ribs, as shown by deformed roof bolts, bolt (header) blocks, landing mats, and crossbars (figs. 20, 24 ; pl. 1). Creep in thin rider coals above the main coal bed locally creates unstable roofs (fig. 25). Deformation by creep is strongest on the right ribs of slopes (looking toward the mine faces) and the downslope ribs of entries, giving many workings a strongly asymmetric appearance. This asymmetry probably results from differential frictional resistance to slip because of preferred orientations of individual mineral grains and sedimentary structures in the roofs (Osterwald and Dunrud, 1965, p. 172). Coal that creeps also slips more easily beneath clay-rich roof rocks than beneath sandstone or siltstone because the friction is less beneath the clay-rich rocks (Osterwald, 1962b, p. 65; Osterwald and Dunrud, 1965, p. 171).

\section{"BASKETS FULL OF ROCKS" (LATERAL SHEAR ZONES IN MINE ROOFS)}

Shear zones as much as $15 \mathrm{~m}$ (50 ft) long form locally near the sites of violent bumps, in mine openings throughout the Sunnyside district (Osterwald and Dunrud, 1965, p. 173). These shear zones occur where the main coal bed is overlain by about $10 \mathrm{~cm}$ (4 in.) of carbonaceous siltstone, above which is another $20 \mathrm{~cm}$ ( 8 in.) of coal (rider seam). The zones are particularly abundant where the rider coal is overlain by several 


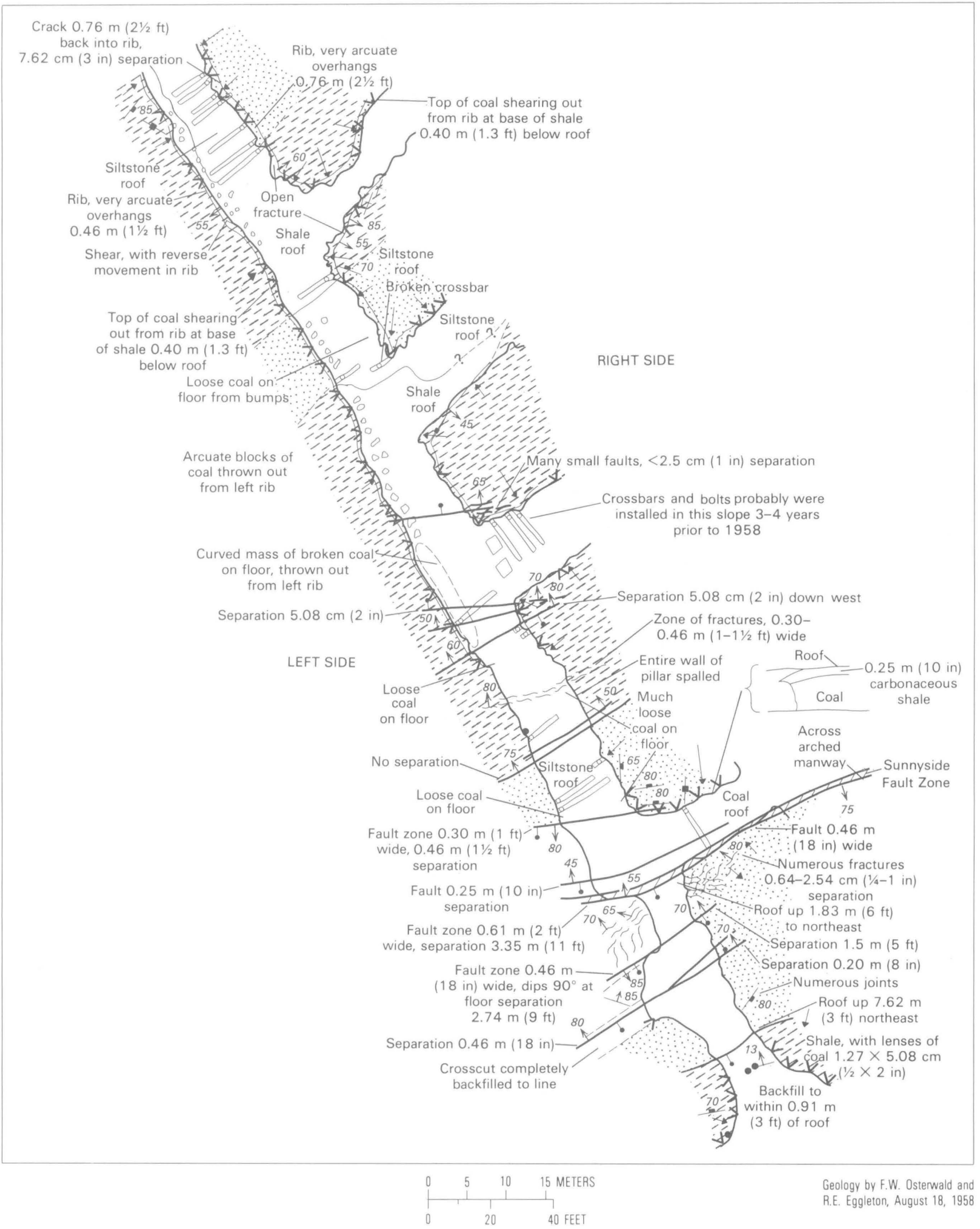

FIGURE 24 (above and facing page).—Underground geologic map of right-hand airway at Sunnyside fault zone, Sunnyside No. 1 Mine, Utah. Scale $2.5 \mathrm{~cm}$ ( $1 \mathrm{in}$.) equals $12.2 \mathrm{~m}$ ( $40 \mathrm{ft}$ ). Plane mapped is roof. 
EXPLANATION

ROCK TYPES AT THE ROOFLINE

Carbonaceous shale

Siltstone

Coal

Contact, dashed where approximately located, queried where doubtful

55

Fault with dip; downthrown side shown by bar and ball,

55 T Fault zone with dip; downthrown side shown by bar and $3.35 \mathrm{~m}\left(11^{\circ} \mathrm{ft}\right)$

$\pi \pi \times$ Bedding-plane shear

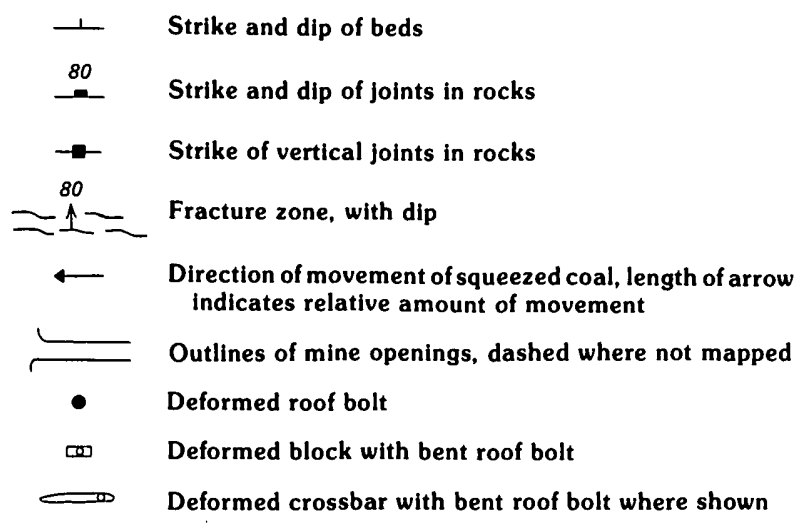

feet of massive, tightly cemented siltstones or sandstones that fill former stream channels. The carbonaceous siltstone is cemented in part by carbonate minerals and contains numerous minute vitrain streaks parallel to bedding planes and parallel to small slump structures. Most of the siltstone is hard and appears to be massive, but, when compressed, it breaks into many small plates with conchoidal fracture. The siltstone is compressed in mine roofs as a result of laterally directed stresses, and it fails in shear along zones oriented at small angles to the trends of mine workings (fig. 7). The remainder of the siltstone adjacent to the failures moves toward the zones by slipping beneath the rider coal. Within the roof shear zones, the siltstone is crushed into lenticular plates about $2.5 \mathrm{~cm}(1 \mathrm{in}$.) thick and $0.76 \mathrm{~cm}(0.3 \mathrm{in}$.) wide. At places where steel landing mats are bolted to the roof and cross these shear zones, the mats are compressed laterally also, the ends of the roof bolts are moved closer together, and the mats form loose loops filled with broken pieces of siltstone which are termed "baskets full of rocks" by miners (fig. 26). Lateral movement of siltstone beneath the rider coal is indicated by the nearly right angle bends in roof bolts that fell out during subsequent bumps. This movement results from shear stresses in the roof (fig. 26). Miners report that "baskets full of rocks" indicate places that might bump. Many bumps, however, are not preceded by the formation of "baskets full of rocks."

\section{FLOOR ANTICLINES (HEAVES)}

Deformation of mine floors by laterally directed stresses (Osterwald, 1961, p. C350-C352; Maberry, 1971 , p. 38) commonly produces domes and anticlines, called heaves by miners, in weak rocks, such as siltstone, shale, and mudstone below the coal bed. Stresses in the uppermost beds of the floor, which are generated as resultants of strong vertical compressive stresses 1 or $2 \mathrm{~m}$ (a few feet) behind the ribs of coal pillars, induce shear along bedding planes in the floor (fig. 27). Lateral movements created by shear couples along bedding planes in the floor cause the uppermost layers to bulge upward, forming floor anticlines or domes. Cores of most such floor anticlines are hollow, and the crests of some are broken vertically in tension by longitudinal fractures and cross faults (fig. 17), some of which have as much as $5 \mathrm{~cm}$ (2 in.) of vertical displacement. Most floor anticlines are oriented with their crestlines nearly parallel to openings, whether slopes or entries, or they diverge from the directions of these openings at small angles (for example, area updip from main parting, pls. 1, 3). Anticlines are as much as $30 \mathrm{~m} \mathrm{(100} \mathrm{ft)} \mathrm{long} \mathrm{and} \mathrm{have} \mathrm{as} \mathrm{much} \mathrm{as} 30 \mathrm{~cm}$ $(1 \mathrm{ft})$ of structural relief.

\section{OTHER TYPES OF HEAVES}

Different structural features, also called heaves by miners, occur where siltstone layers in the floor are thicker than the layers at the sites of floor anticlines. When subjected to lateral stress components, the thick layers, mostly in coarse-grained siltstones or sandstones, fail by shearing along bedding planes in the floor. The shear planes commonly curve downward near one rib or the other, forcing slabs of rock violently upward into the openings (fig. 28). Some heaves of this type nearly fill mine openings, and many were followed within a few minutes to a very few days by violent bumps in nearby openings. These heaves indicate very high stress concentrations.

\section{ROOF SYNCLINES} (HORSEBACKS)

Deformation of unsupported roofs, or of roofs only lightly supported, commonly produces roof synclines (called horsebacks by miners) that are nearly parallel 


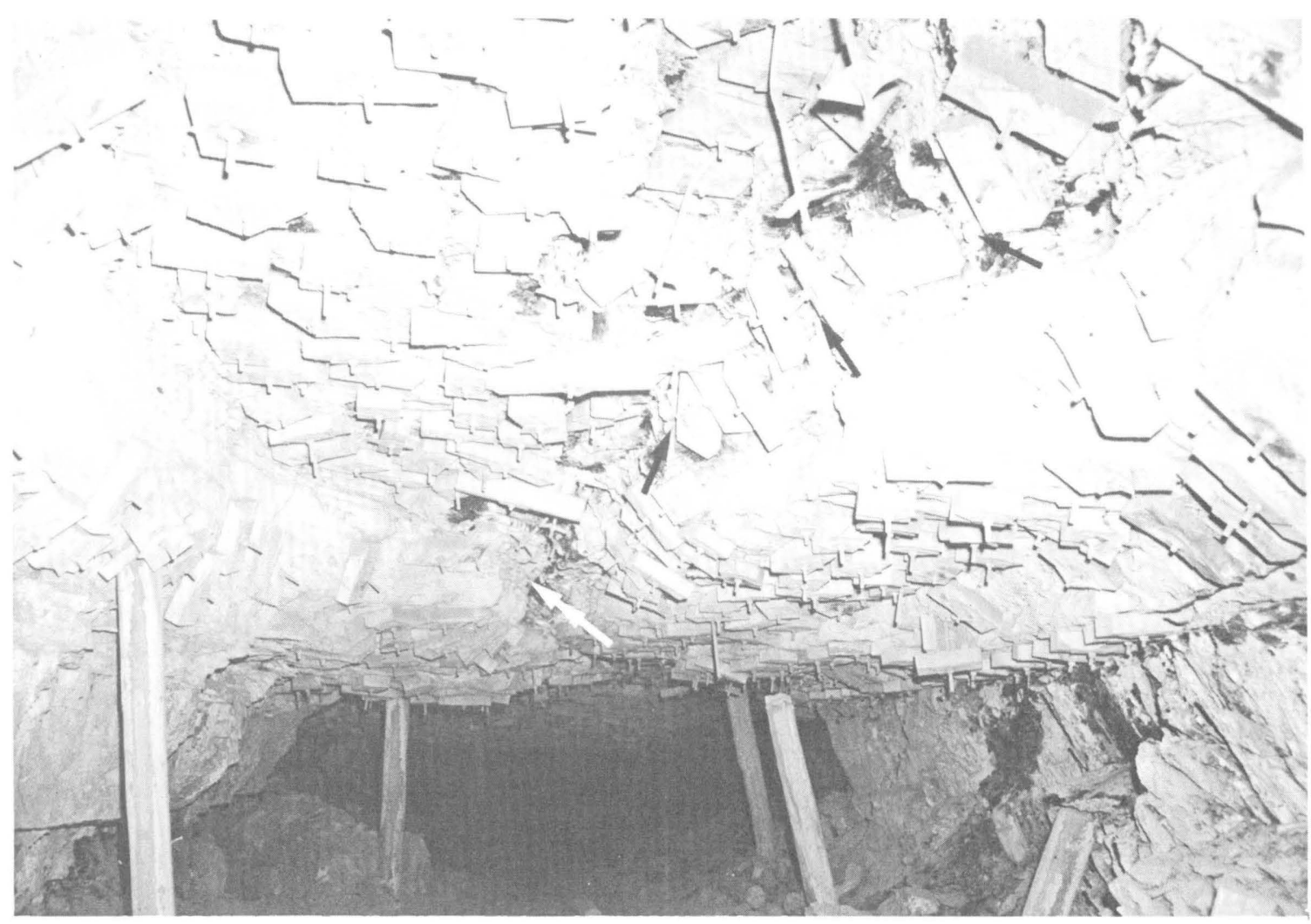

FiguRE 25.-Thin rider coal, $3.1 \mathrm{~m}$ (10 ft) above floor, is creeping from right, partially covering roof bolts (arrows) installed 5 years before picture was taken. Coal on left side is also moving toward opening, bending roof bolts and

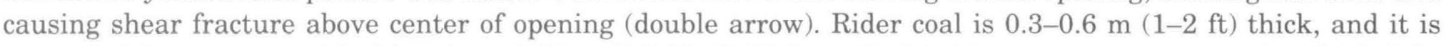
separated from main coal bed by about $0.76 \mathrm{~m}(2.5 \mathrm{ft})$ of siltstone. Right-side manway, between $2 \mathrm{~d}$ and $3 \mathrm{~d}$ right entries, Sunnyside No. 1 Mine, Utah. Photograph by J.C. Witt.

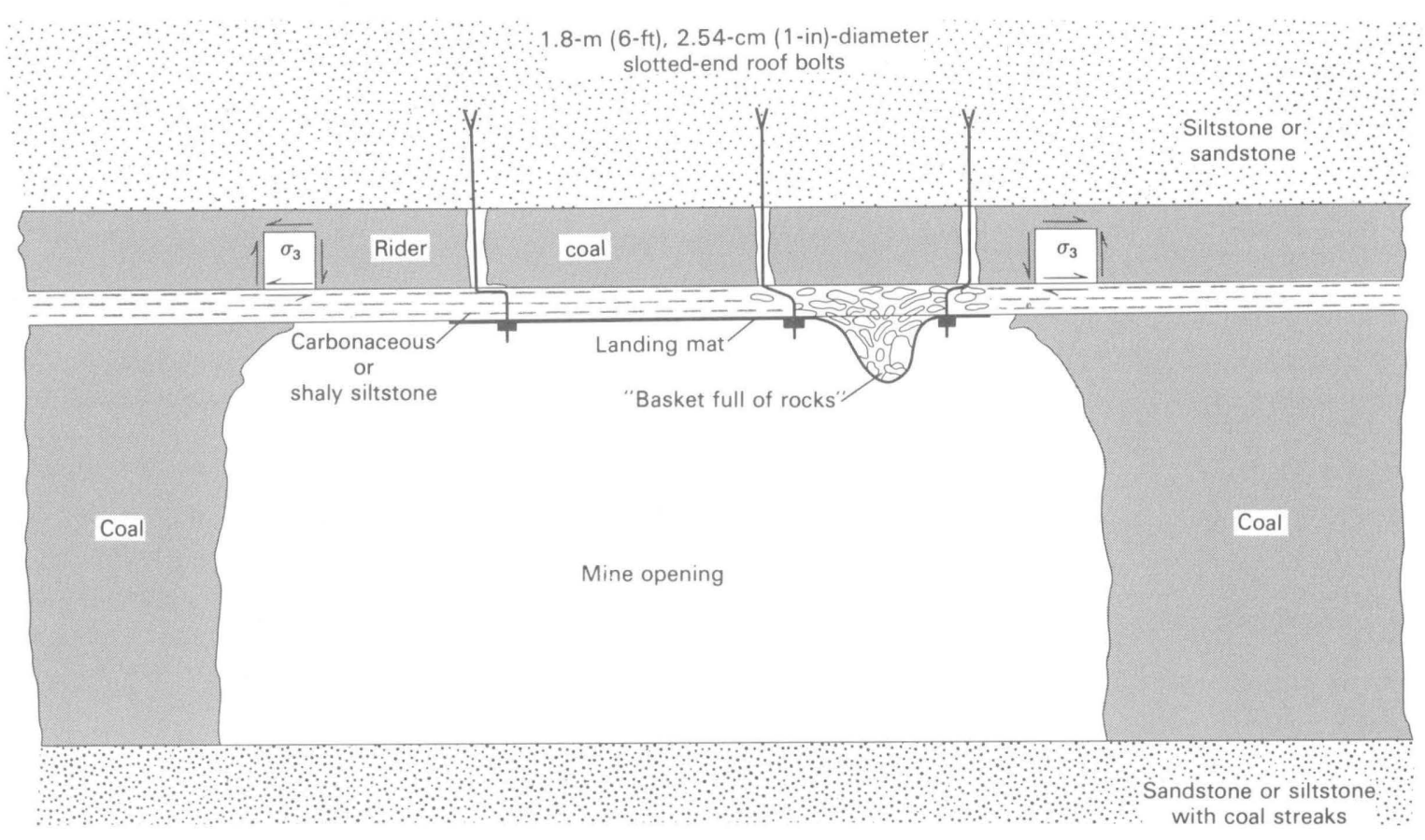

FIGURE 26.-Diagrammatic vertical cross section through mine opening showing failure of carbonaceous siltstone in mine roof along linear shear zone and a "basket full of rocks." Modified from Osterwald and Dunrud, 1965, figure 9 . 


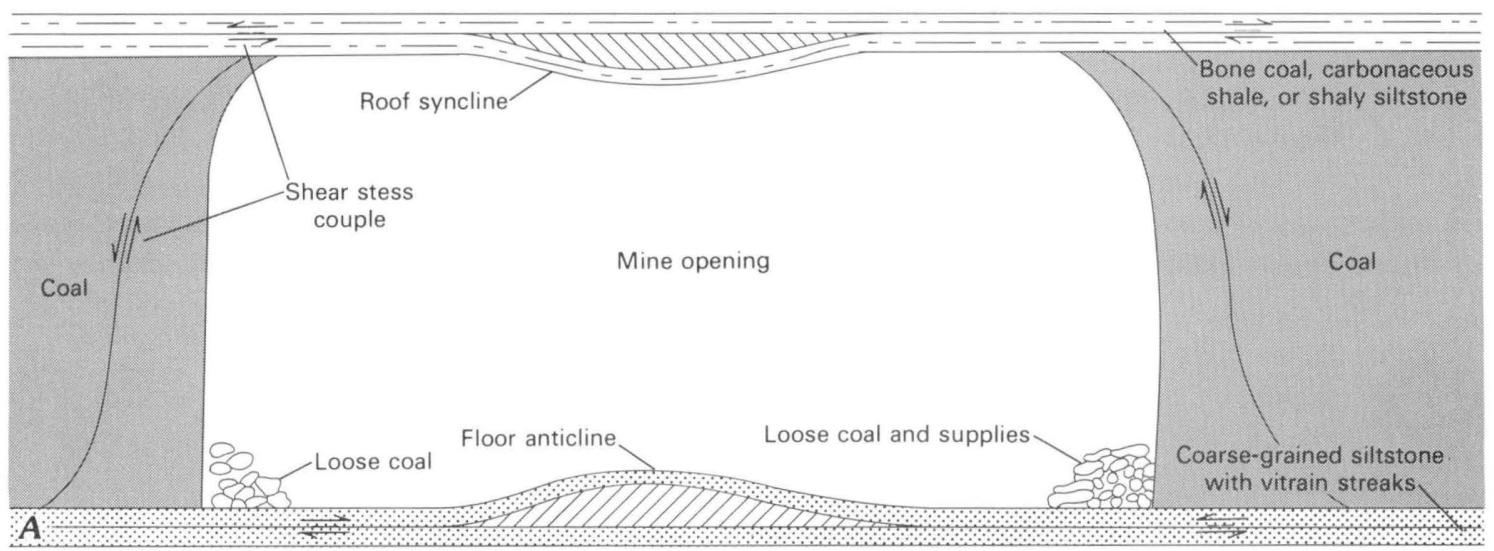

$A$, Roof syncline, floor anticline, curved shear fractures, and shear stress couples where coal slips along clayey roof but adheres to coarse-grained siltstone floor; diagonally ruled areas are hollow. Modified from Osterwald (1961a, p. C352) and from Maberry (1971, p. 38, fig. 45).

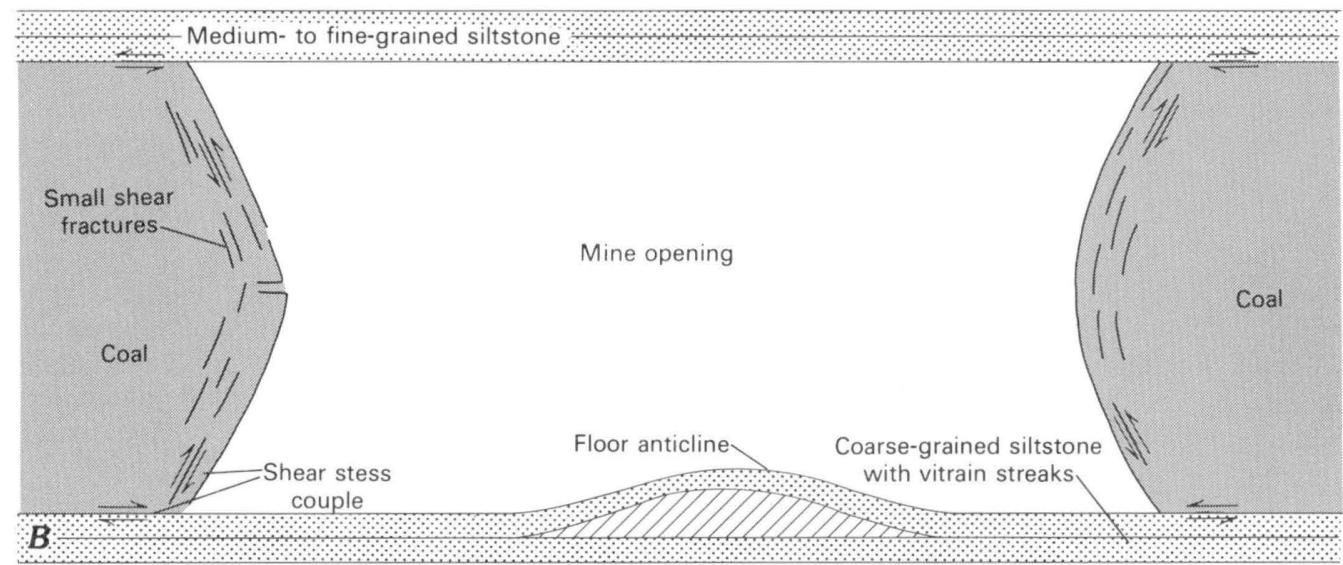

$B$, Bulged and buckled ribs where coal adheres to roof and floor; diagonally ruled area is hollow. Modified from Osterwald (1961a, p. C352) and from Maberry (1971, p. 38, fig. 45)

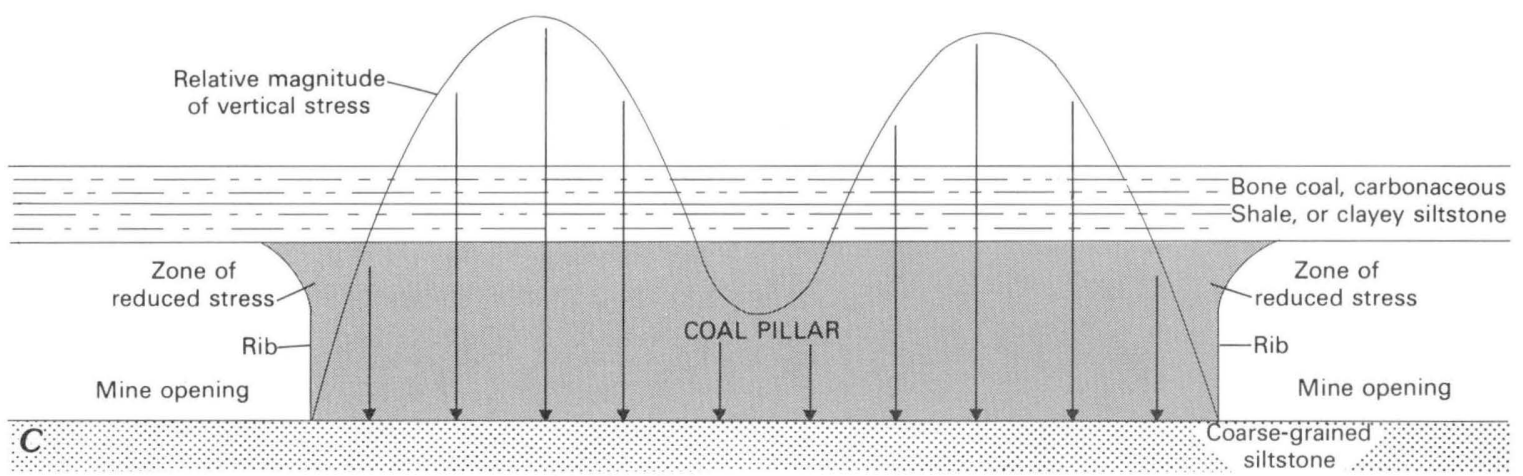

$C$, Stress concentrations near mine ribs, reduced stress at rib surfaces, and decreased stress concentration in pillar core. Stress concentrations are modified from theoretical elastic distribution because the release from confinement at the pillar surface (rib) produces a narrow zone that sustains little stress. Arrows indicate relative magnitude of vertical stress; the curve is the envelope of relative stress magnitude. Highest stress zones are inside pillar boundaries (ribs). Modified from Coates (1970, fig. 4-1). 


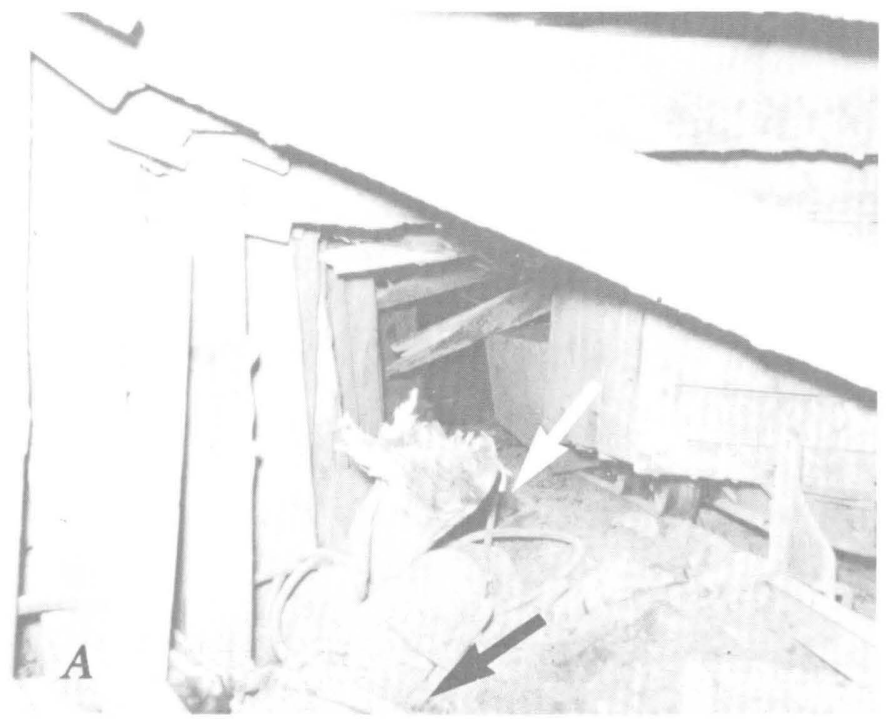

A, In Sunnyside No. 2 Mine, in the early 1950 s, heave forced mine car against roof. Shear crack in floor along right side of row of timbers (arrows) caused large slabs of rock to force the track upward. Additional laterally directed high stress components in roof sheared roof crossbars (broken timbers in background). Photograph courtesy of W.R. Muehlberger.

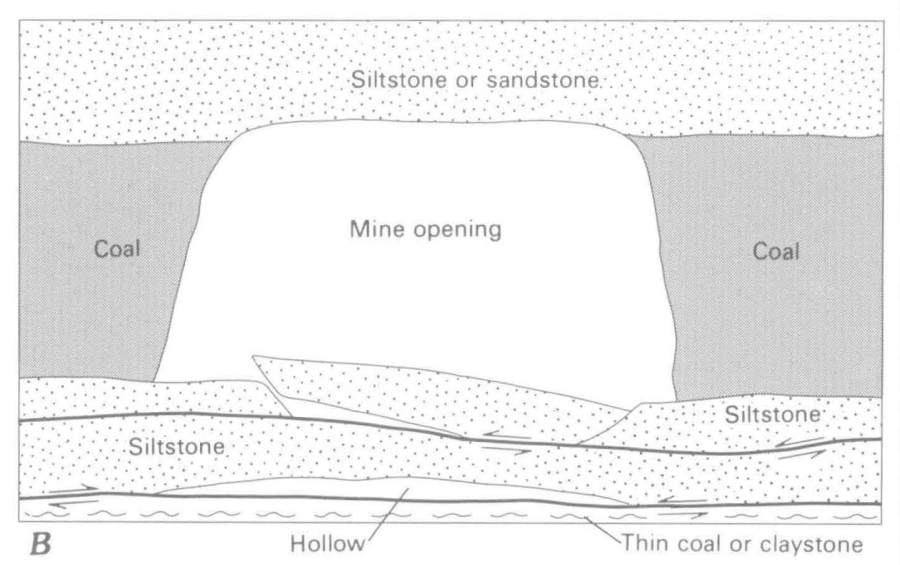

$B$, Shear failure of stiff floor rocks resulted from lateral stresses. Arrows indicate direction of shear on bedding planes.

FIGURE 28.-FAILURES OF FLOOR (HEAVES)

to slopes (fig. 16). Such synclines result from lateral stresses in the lowermost beds of the roof (fig. 27A). Vertical tensional stress along the troughs of the synclines commonly produces small fractures parallel to the mine openings, which allow blocks of rock to loosen and fall into the openings.

Roof synclines form where uniformly bedded clayrich rocks overlie coal beds. These synclines are especially pronounced in a few places near the main motor road parting at the main slopes of Sunnyside No. 1
Mine. Many roof synclines have hollow troughs, similar to the cores of floor anticlines, and probably are similar in origin to the anticlines (Osterwald, 1962b, p. 67-68). Most roof synclines are oriented with their troughs parallel to slopes; similar structures, nearly monoclinal in configuration, form with their synclinal bends almost parallel to entries, probably because gravity down the dip of beds directs the shear-induced slip along bedding planes in the roof.

\section{BUCKLED RIBS}

Where coal adheres to the roof rocks, ribs of mine openings bulge into openings and buckle, forming irregular breaks nearly parallel to the floor along bedding planes or thin shale splits in the middle of the ribs (for example, between 6th and 7th right entries, fig. 29; pl. 1). Small shear fractures form behind bulged and buckled ribs, loosening slabs of coal that can be thrown violently into the openings during bumps (fig. $27 B$ ). Whether ribs fail under lateral stresses by buckling, by forming curved shear fractures, or by slipping along bedding-plane shears probably is governed both by the lithology of the roof-because sandy or silty rocks impart more friction to bedding planes than do clayey rocks - and by original sedimentary features along the bedding planes. Such features as ripple marks, channel fills, load casts, crossbeds, slump structures, and trace fossils impart pronounced but variable differences in the frictional properties of the bedding planes in different directions (Osterwald and Dunrud, 1965, p. 172; Maberry, 1968, 1971).

\section{INFLUENCE OF FLOOR AND ROOF ROCKS ON DEFORMATION OF OPENINGS}

\section{LITHOLOGIC AND STRUCTURAL CHARACTERISTICS}

The Sunnyside coal bed overlies a discontinuous sandy siltstone less than $1.8 \mathrm{~m}(6 \mathrm{ft})$ thick which is located above a thick sandstone unit at the top of the Sunnyside Member of the Blackhawk Formation (Maberry, 1971, p. 28). The sandy siltstone and the thick sandstone are the floor rocks for the Sunnyside mines. The thin sandy siltstone and the Sunnyside coal bed are the lowermost units of the upper mudstone member of the Blackhawk Formation (Maberry, 1971, p. 30-31). The beds above the Sunnyside coal in the upper mudstone member, which make up the roof rocks for the coal mines, consist of about 76-91 m $(250-300 \mathrm{ft})$ of dark laminated shale and massive mudstone with lenticular bodies of sandstone and 


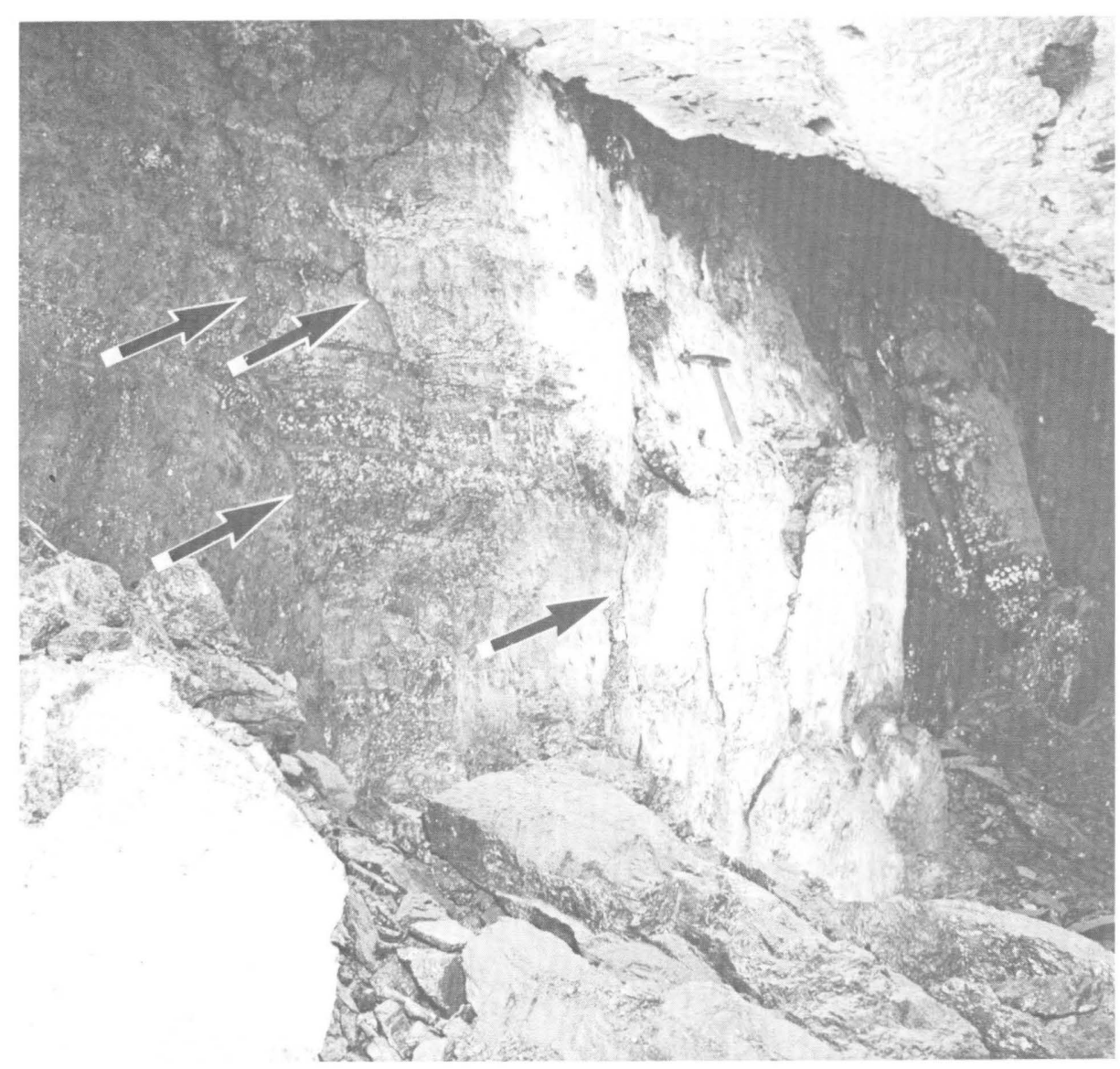

FigURE 29.-Rib of coal pillar bulged and buckled into opening along a small shale split. Small shear cracks formed behind surface (arrows). White areas are where coal is coated with powdered limestone. Photograph taken between 6th and 7th right entries, right-side manway, main slopes, Sunnyside No. 1 Mine, by J.C. Witt. Hammer handle is about $30.5 \mathrm{~cm}$ (1 ft) long.

siltstone throughout. Directly overlying the coal bed is a sequence of very carbonaceous shales, mudstones, siltstones, and lenticular sandstones and siltstones containing numerous horizontal burrows, labyrinth castings, and shrimp (Ophiomorpha) burrows (Maberry, 1971, p. 30). The lithologic and structural characteristics of these roof and floor rocks profoundly influence the deformation of coal mine openings in response to stress changes during mining.

The different rock types are related to areas in which different types of post-mine deformational features formed in the coal and around the openings (pls. 1-4). Chief among the variations in roof rock type that are related to different types of post-mine deformation are (1) thick, tightly cemented sandstone layers above the main coal bed that do not cave immediately when pillars are removed, thereby increasing the stress on nearby working areas; (2) clayey roof rocks beneath which coal slips easily in response to lateral stresses, allowing pillar failure along curving shear fractures;
(3) sandy or silty roof rocks whose coefficient of friction with the coal is greater than that of clay-rich rocks, causing pillars to bulge outward and to fail along many small fractures parallel to the openings; (4) brittle carbonaceous siltstones above the coal, which break up into numerous small chips when compressed, commonly along linear shear zones nearly parallel to the trend of the openings; and (5) moderately thick sandstone-filled channels in the roof, which, if closely jointed and only moderately well or loosely cemented, make good roofs for mining operations and cave easily when pillars are removed, causing no undue stresses on nearby working areas. Scheibner (1979, p. 75-83) described in detail the petrography of roof and floor rocks from the 16th left, 17th left, and 18th left entries of the Sunnyside No. 1 Mine (northeast of the area shown on pl. 1). Scheibner also described some of the rocks from the 16th left entry of the Sunnyside No. 2 Mine (1979, p. 85-106), which is east of the northeastern part of the mine shown on plate 3 . 


\section{STRATIGRAPHIC CHARACTERISTICS}

The stratigraphic sequence of rocks above the coal bed as well as the lithology of the immediate roof markedly influences the deformation of mine openings (including bumps) in the Sunnyside district. The observation that stratigraphy above a mined coal bed is an important factor in the behavior of mining faces was made long ago in New South Wales by Carne (1903, p. 84), who noted that where soft bituminous coal overlay a mined bed of cannel coal no bumps occurred, but that "wherever hard brittle cannel coal lies on top of the beds a continuous and violent rebounding of particles takes place." The complex stratigraphy of the rocks overlying and underlying the coal in the 16th left, 17th left, and 18th left entries of Sunnyside No. 1 Mine was clearly demonstrated by Scheibner (1979, p. 10), who constructed cross sections along each entry based on logs of holes drilled upward and downward from the mine openings. These entries were opened after our fieldwork was completed and, hence, are not shown on plate 1 . Scheibner's cross sections show complicated intertonguing relationships of rocks associated with the coal. In the area studied by Scheibner, the mine openings apparently were in an upper split of the Sunnyside coal bed, and so the openings were underlain by nearly $3 \mathrm{~m}$ ( $10 \mathrm{ft}$ ) of coal as well as by the variable thicknesses of siltstone and sandstone that overlie the major sandstone beds of the Sunnyside Member of the Blackhawk Formation. Mine openings in Scheibner's area, therefore, probably would deform in response to stress changes in a different way than the older openings that we studied, most of which are underlain directly by the thick sandstone beds of the Sunnyside Member.

Stratigraphic sequences in roof rocks consisting of coal overlain by carbonaceous siltstone, rider coal, and thick-bedded siltstone or sandstone filling paleostream channels have a marked effect on bumps and on some mining practices in the Sunnyside district. During normal room-and-pillar mining operations, attempts are made to remove all coal pillars and to allow the roof to collapse completely behind the pillar line. This practice reduces the abutment stress on actively worked faces and lessens the hazards from bumps. The combination of siltstone, rider coal, and thick-bedded sandstone or siltstone, when roof bolted, does not always cave properly behind pillar lines, especially when a new pillar line is being established. Bumps then can be caused by increased abutment stresses in coal behind the ribs. Numerous violent bumps that occurred within $460 \mathrm{~m}$ (1,500 ft) of and downdip from the Sunnyside fault (pls. 1,4) may have resulted from mining beneath such a stratigraphic sequence. Good roof conditions and fair pillar extraction, with few bumps, could be obtained in some places by mining the carbonaceous siltstone and the rider coal with the main coal bed. This practice prevents deformation of the weak rocks above the coal and induces failure (caving) of the overlying thick-bedded units by increasing the lateral stresses within them.

The stratigraphy of the floor rocks also markedly influences the deformation of the coal and the mine workings. Shale or thin-bedded siltstone, 1-2 $\mathrm{m}$ (a few feet) thick, locally separates the coal bed and the thick sandstone unit of the Sunnyside Member. These thinbedded rocks slip easily beneath coal, making floor heaving easy. The same rock types are also a major source of trouble in longwall mining, especially in the northeastern part of the Sunnyside No. 1 Mine, because they yield beneath the mechanical jacks (props) used to support the roof. These jacks normally are advanced immediately after each cut is made along the longwall face, but they stick in the weak shales and will not advance because the floor yields.

\section{SEDIMENTARY STRUCTURES}

Both biogenic and inorganic sedimentary structures in the roof influence the deformation of mine workings in the Sunnyside district (Maberry, 1971, p. 39-40). Similar structures in floor rocks probably influence deformation of mine floors and the lower parts of mine pillars, but they cannot be observed in the mines. Many sedimentary structures in the roof rocks are strongly directional and, hence, impart strongly directional (or asymmetric) deformational features to the mine openings. These features have resulted from directional differences in frictional resistance to lateral slip of coal in varying directions. We first attributed the asymmetric deformational features to oriented differential tectonic stresses, but because sedimentary features in the Blackhawk Formation indicate that the ancient streams flowed generally east and southeast (Maberry, 1971 , p. 30, 36), we later recognized that these features are nearly parallel to the general directions of stream flow during deposition of the roof rocks. Deformation of most mine openings is strongest on the southeast or downstream side of the openings, because of the high frictional resistance to slip of coal in other directions that is imparted by the orientations of quartz grains, crossbeds, and other sedimentary structures. Although shear along top and bottom contacts of coal beds was recognized by Jeremic $(1980$, p. 32-37) as an important factor in coal-mine deformation in western Canada, he did not consider the effect of sedimentary structures on 
the amounts and orientations of the movements resulting from the shear.

\section{SEDIMENTARY STRUCTURES WITH PREFERRED ORIENTATIONS}

Sedimentary structures that impart directional characteristics to deformed mine openings include foreset and bottomset crossbeds, sand grains that are preferentially oriented, large horizontal burrows filled with siltstone or sandstone, current ripple marks, and sandstone-filled channels (Maberry, 1971, p. 39). Other sedimentary structures that have no preferred orientation but which change the friction between coal and rock include load casts, intertongued contacts, and interfaces between rocks of markedly different physical properties.

\section{CROSSBEDS}

Foreset and bottomset crossbeds in rocks above the coal influence the deformation of mine openings by impeding the slip of underlying units in directions opposite to the dip of the crossbedding. Where crossbeds intersect bedding at small angles, slip of underlying units is favored in directions parallel to the dip of crossbeds. In some mine openings asymmetric deformational features are produced by the differential ease of slip where the dip of crossbeds above the coal is oblique to the trends of the openings. In roof rocks, sand grains having preferred orientations that are parallel to directions of paleostream flow also produce asymmetric deformation of mine openings because the slip on bedding planes at the bottoms of the sandstone units is easier parallel to the lengths of the quartz grains than it is parallel to the widths of the grains (Harold Brodsky, oral commun., 1961).

\section{TRACE FOSSILS}

Large horizontal burrows are cavities that formerly were domiciles of bottom-living organisms and now are filled with sandstone or siltstone. The burrows resemble the trace fossil Planolites and occur commonly above coal beds in the Sunnyside district (fig. 30; Maberry, 1971, p. 39). They are oval in cross section; and many are aligned northeastward, subparallel to the strike of ripple-mark crests (Maberry, 1971, p. 16), or nearly normal to the direction of flow of the water currents in which they lived. The burrows, referred to as "fingers in the roof" by miners, appear as numerous, elongated, irregularly tubular forms varying in diameter from about 0.6 to $6.55 \mathrm{~cm}$ ( $1 / 4$ to $2 \frac{1}{2}$ in.). They are found in carbonaceous silty, or sandy, mudstone mine roofs; most are tightly cemented and project downward. They are particularly abundant and well exposed in the roof of the motorman's shelter at the main parting in Sunnyside No. 1 Mine (pl. 1; fig. 31). The burrows immediately above the coal have a pronounced effect on the directional symmetry of deformation of mine openings because bedding-plane slip is much easier parallel to their lengths than it is across their widths (fig. 31). The lengths of the burrows resist transverse movement much more than the widths of the burrows resist movement parallel to the lengths.

\section{CURRENT RIPPLE MARKS}

Current ripple marks are asymmetric in cross section and have gently sloping upstream sides and steep downstream sides. Rocks beneath a bedding surface that includes current ripple marks thus slip more easily in directions perpendicular to the direction of current flow than in directions parallel to streamflow.

\section{PALEOSTREAM CHANNELS}

Sandstone-filled paleostream channels impede bedding-plane slip during deformation of mine openings, particularly where the channels extend downward into the coal. Such channels block bedding-plane slip in directions across the channels, but they only slightly impede slip parallel to the lengths of channels. Most such channels in the northern part of the Sunnyside district trend about south and southeast, except in paleostream meanders, so that slip beneath channels generally is restricted to directions nearly north and northeast. Widely divergent directions, however, occur where channels curved or meandered, as in the southern part of the Geneva Mine (Osterwald and Maberry, 1974), in the southern part of the district (fig. 1).

\section{SEDIMENTARY STRUCTURES WITH NO PREFERRED ORIENTATION}

Many sedimentary structures have no preferred orientations. Numerous kinds of such structures are known, varying widely in form and size. The origins of many are obscure.

\section{LOAD CASTS}

Load casts are the most abundant sedimentary structures in the rocks immediately above the coal. 


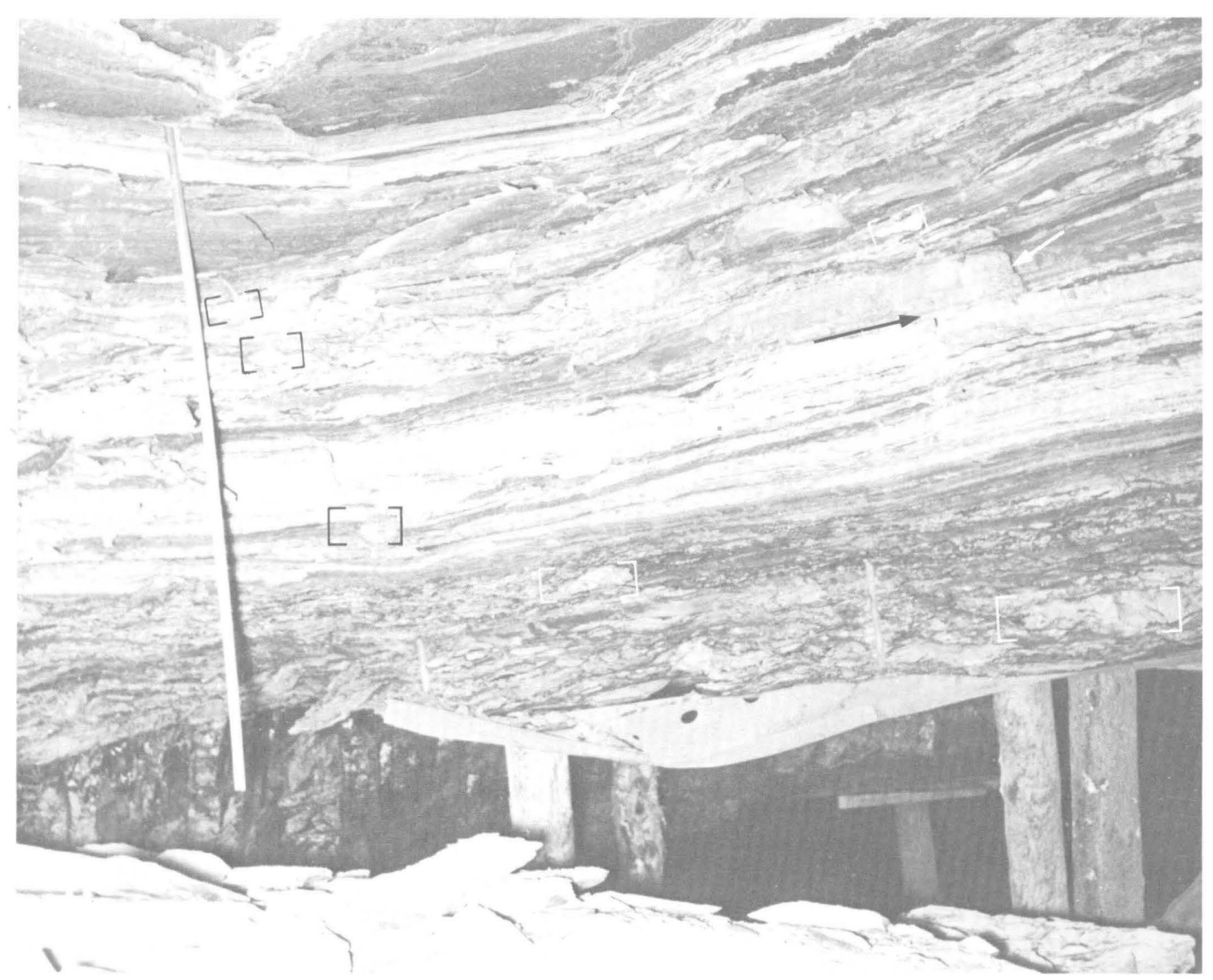

Figure 30.-Downdip side of dome-shaped cavity in roof at intersection, 7th east-slope manway, Columbia Mine, Utah. Lowermost layer of roof, about $1.1 \mathrm{~m}(3.5 \mathrm{ft})$ of siltstone with many large horizontal burrows, was compressed by lateral stress components and broken (at left end of bent steel plate). Several examples of burrows indicated by brackets. Conjugate shear fractures at right side of picture (arrows) probably resulted from vertical components of compressive stress. Debris at bottom of picture fell from roof during caving.

Most of these casts consist of bowl- or biscuit-shaped convex forms (Maberry, 1971, p. 36-37) that project downward as much as $30 \mathrm{~cm}(1 \mathrm{ft})$ from mine roofs. Such load casts are formed by settling of sedimentfilled depressions on soft mud beds; they are most common where sands are deposited on clay-rich sediments. Mine roofs containing numerous, small, closely adjacent load casts as much as $13 \mathrm{~cm}$ (5 in.) in diameter are referred to as bumpy beds by miners at Sunnyside and are thought to indicate localities where severe bumps are not apt to occur. Although this relationship may have been true during initial mining for development, it probably is not true during later mining for extraction, because the nondirectional irregularities in the roofs that are produced by the load casts restrain bedding-plane slip above the coal bed. This restraint probably allows stress to accumulate in mine ribs where it would otherwise be relieved gradually by slip. Accumulated stresses then can cause bumps or compressive roof caves when pillars are removed.

\section{INTERTONGUED CONTACTS}

Intertongued contacts between rock units effectively inhibit bedding-plane slip in most directions. Although slip may occur parallel to the long dimension of some individual tongues, other tongues along the same rock interface may prevent slip in that direction. Intertongued contacts between the Sunnyside coal bed and overlying siltstone or carbonaceous siltstone are particularly well displayed in the main slopes of Sunnyside No. 1 Mine, updip from the main hoist (pl. 1; fig. 32). By preventing bedding-plane slip, the intertonguing of such contacts at the top of the coal tends to permit stress to accumulate behind mine ribs and above mine roofs and, locally, to cause violent bumps and roof caves.

\section{STRESS DISTRIBUTION AROUND MINE OPENINGS}

Analysis of the post-mine deformational (structural) features in the mines of the Sunnyside district strongly 


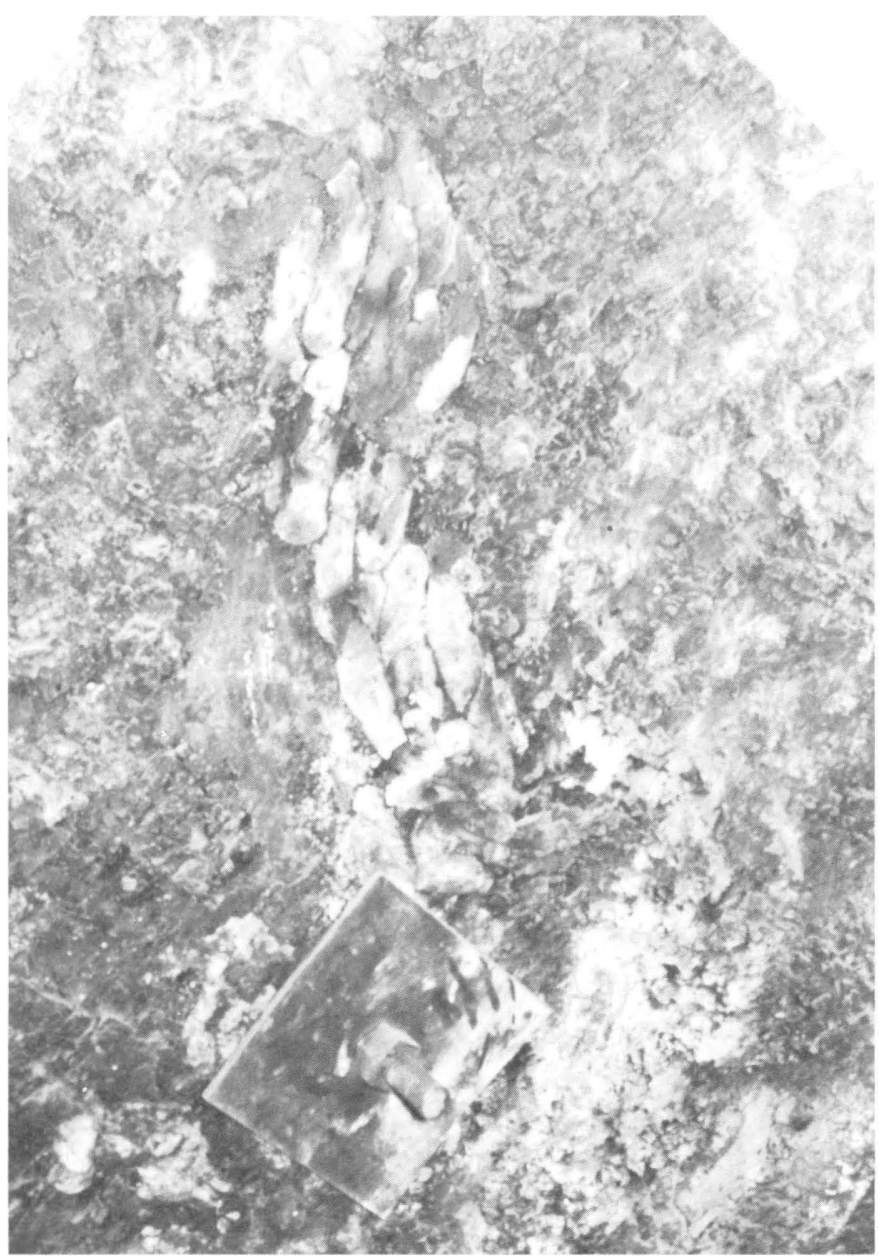

Figure 31.-Large horizontal burrows in siltstone above the Sunnyside coal bed, in roof of motorman's shelter at the main parting, Sunnyside No. 1 Mine, Utah. Scale indicated by roof bolt plate which is about $15.24 \mathrm{~cm}$ (6 in.) in diameter. indicates that high compressional stresses caused much of the observed deformation. Furthermore, the deformational features indicate that deformation resulting from lateral compressive stress commonly is greater than deformation from vertical stress (load). Small deformational features in the mines, and the distribution and intensity of rock and coal failures, provide insights into the stress distribution around the mine openings. Deformational features, limited to areas less than a few tens of feet across, are caused by tensile stresses, and most are small and clearly of superficial origin. Even such large deformational features as massive roof caves along slopes and haulage entries in the Sunnyside No. 1 Mine probably resulted from lateral compressive stresses (Osterwald and Dunrud, 1965, p. 171-172). Other types of roof caves, such as roughly dome-shaped drop outs at intersections of openings in the Columbia Mine (fig. 30), may result from vertical tensile and shear stresses that locally exceed the strength of the rocks. These types of roof caves, however, are smaller than the massive caves, involve different types of roof rocks, and produce different patterns of deformational features.

The lateral compressive stresses probably are generated as resultants of vertical stresses in areas where the rocks are laterally restrained. The magnitudes of such lateral stresses depend in part upon Poisson's ratios of the materials. Where the coal and rocks are subjected to high vertical compressive stresses, lateral strains are induced, causing lateral extension toward openings or lateral compression where the materials are laterally restrained and no artificial openings exist. Such lateral deformation resulting from vertical compressive stress is sometimes referred to as Poisson's

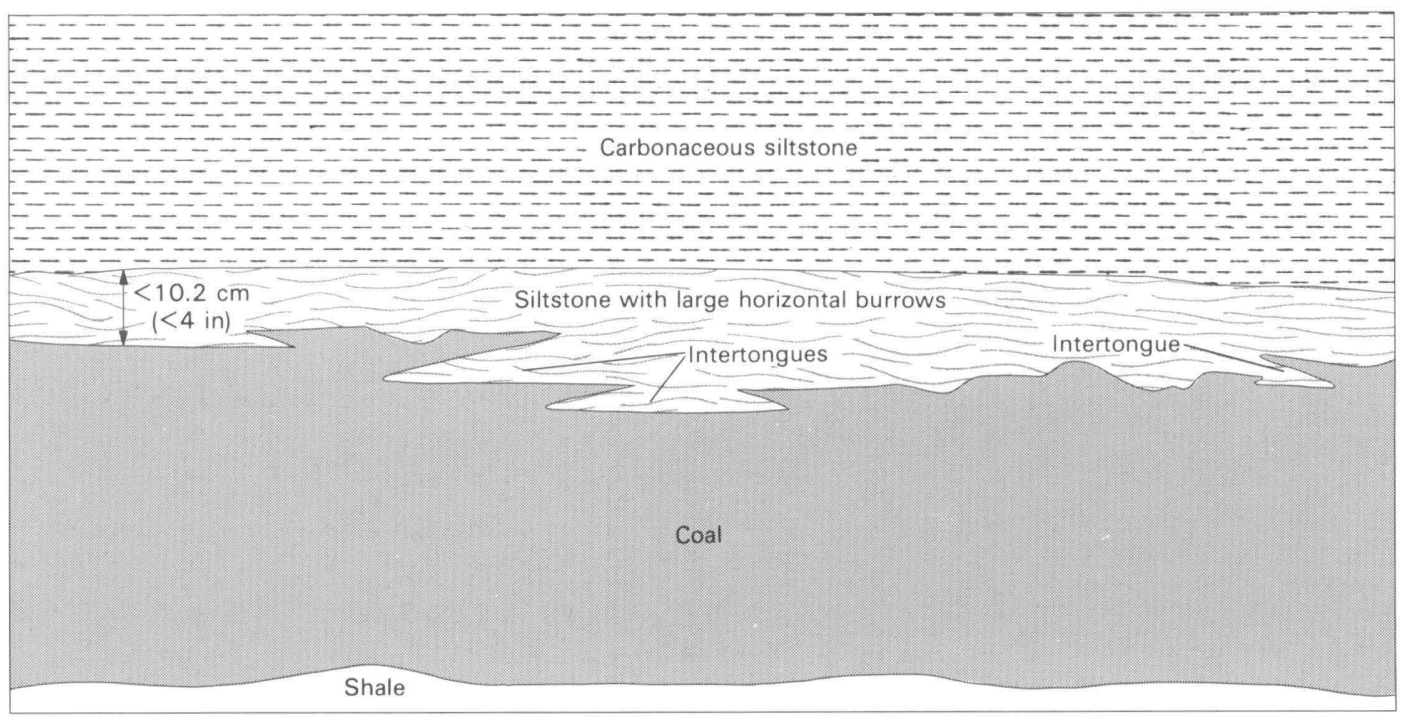

FigURE 32.-Diagrammatic sketch of intertongued coal and roof rocks, main slopes above main hoist, Sunnyside No. 1 Mine, Utah. 


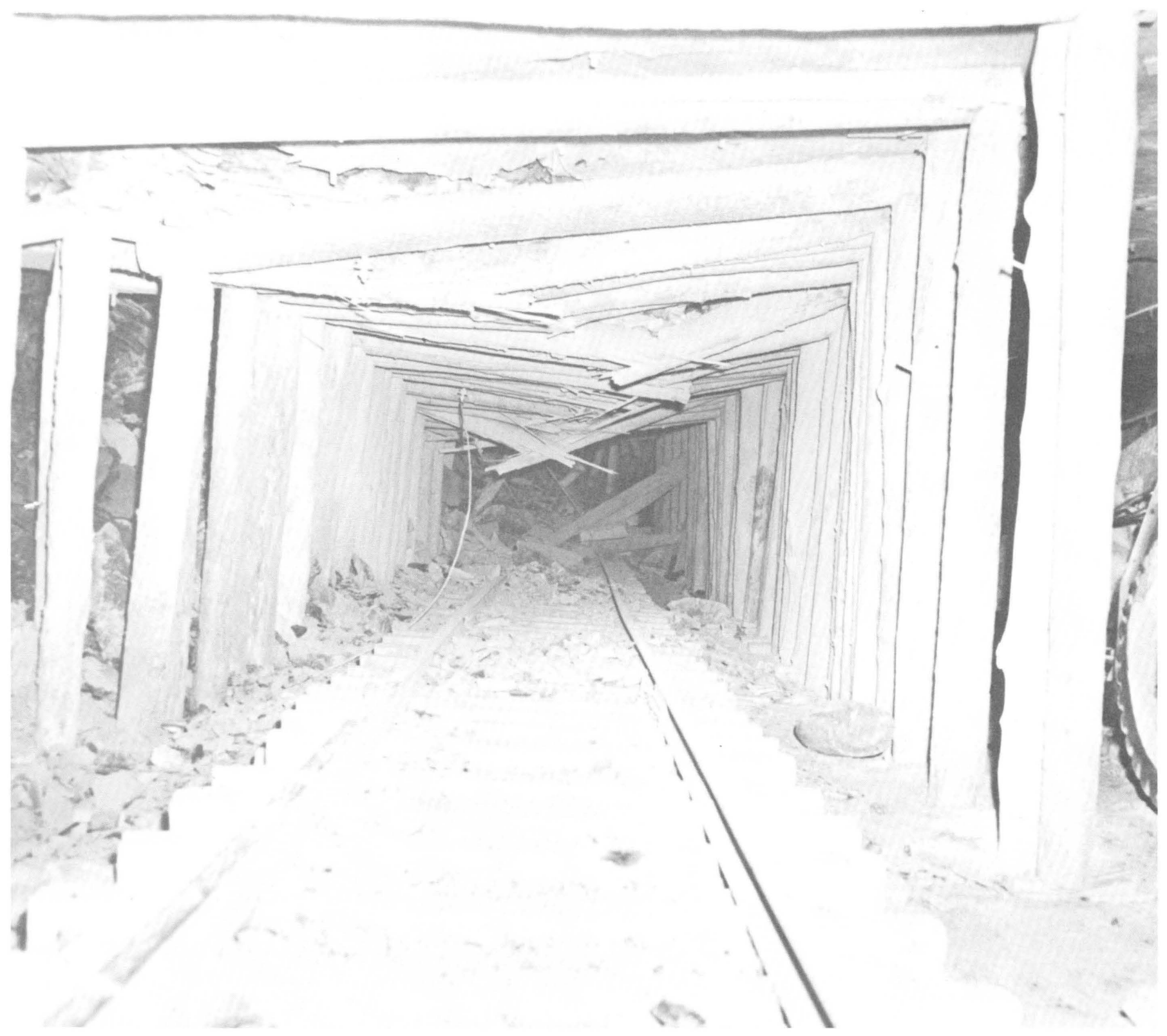

Figure 33.-Crossbars in Sunnyside No. 2 Mine broken by lateral components of compressive stresses because rib coal moved against ends of beams. Where track rises in background, mine floor has heaved. Crossbars in foreground do not touch the ribs and are not subjected to lateral compression. Loose coal on left side of opening in background resulted from bump. Photograph by J.C. Witt.

Effect (Coates, 1970, p. 1-3). Lateral restraint (and Poisson's Effect) also increases the friction on steeply dipping fracture planes, inhibiting failures from local tensile stresses (Evans, 1941; Corlett and Emery, 1959, p. 377-381; Woodruff, 1966, p. 282-294.

Small deformational features within the mine openings that indicate high lateral compressive stresses include curved shear fractures and smooth planar fractures in coal and rock. Other indications of high lateral compressive stresses include deformed roof bolts; bent landing mats; broken crossbars; bent, broken, and tilted timbers; and bent mine track. Bent landing mats (fig. 16) and broken crossbars (fig. 33) provide the clearest evidence of high lateral stresses. Because coal that is moved into openings beneath bedding-plane shears expands slightly, as a result of lateral compressive stresses, numerous superficial tension cracks form in the coal. Where fracture zones are present, the expansion causes individual fractures to open slightly. The slow movement of this coal, which is loosened because of expansion and cracking, produces many slivers and columns of coal that separate from ribs and fall into openings (fig. 34). Coal also moves into some openings by creep (fig. 25). 


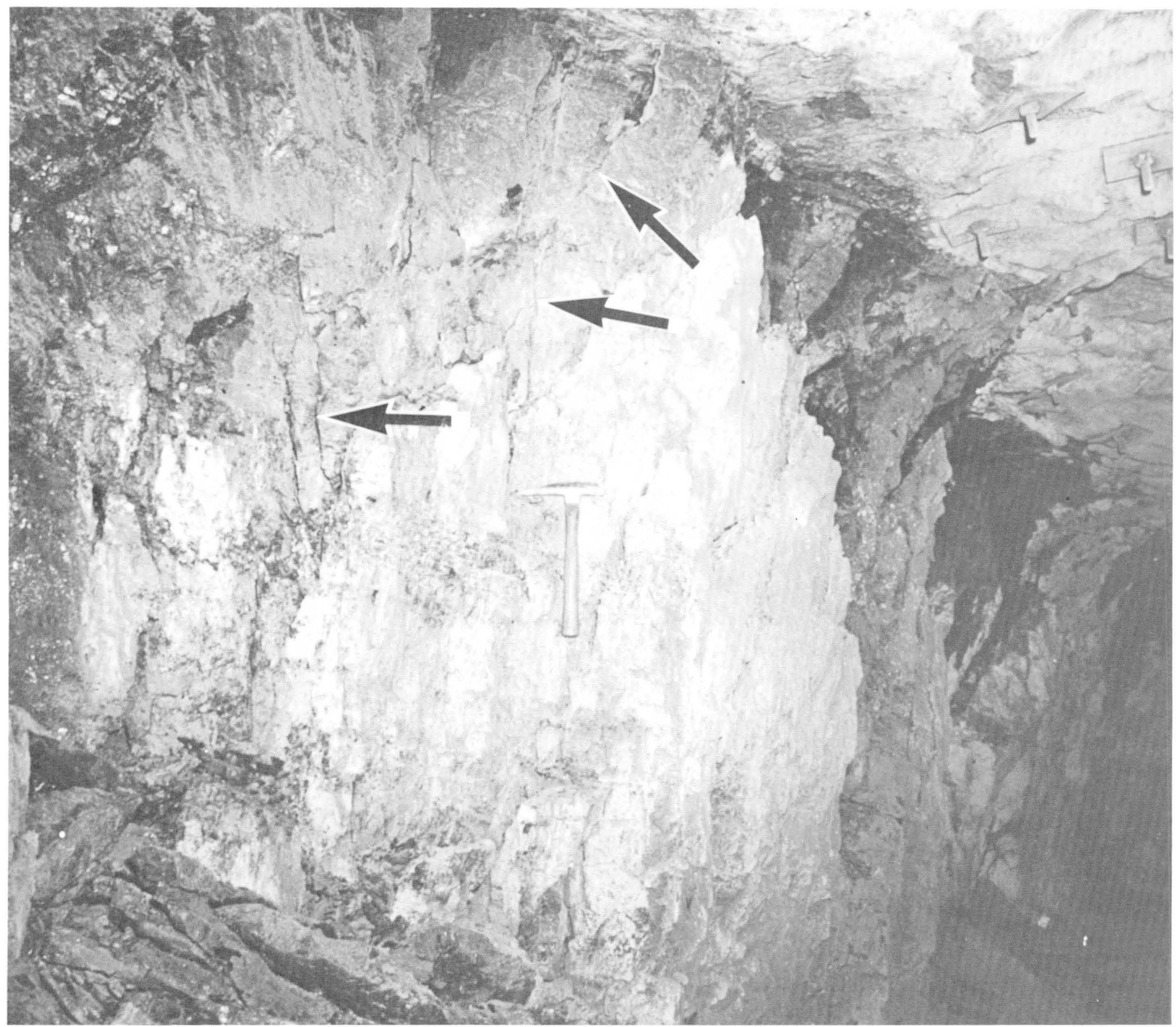

FIGURE 34.-Coal expanding into mine opening, producing numerous small tension cracks (arrows) and forming splinters and columns of coal that fall into openings. Splinters and columns of coal are much taller and fall farther into openings where entire ribs move into openings than where ribs buckle in the center (fig. 29). Hammer handle is about $30 \mathrm{~cm}(1 \mathrm{ft}$ ) long. Right-side manway, near $2 \mathrm{nd}$ right entry, main slopes, Sunnyside No. 1 Mine. Coal is dusted with powdered limestone (light areas). Photograph by J.C. Witt.

Deformation of weak roofs or roofs that are not strongly supported commonly produces "synclines" (fig. 16). Deformation of roofs that are strongly supported by timbers, crossbars, and roof bolts is different from that of such weak roofs. Many wooden crossbars are bent downward and snapped off (fig. 33). The bending and breaking are not the results of downward pressure because the timbers and the rocks above them fail in shear, not in tension. Lateral stresses against the ends of the crossbars and against the rocks above them forced the timber and rocks downward into the openings. We also traced breaks in some crossbars upward into shear fractures in the roof. Many other roof areas in the Sunnyside mines are strongly supported by yieldable steel arches. Because of the construction of the arches and the backfilling behind many of them, however, we could not study deformed ribs and roofs in openings supported by arches.

Massive sandstones or siltstones in the roof formed rigid plates during mining and extraction of pillars. Such rigid plates in mine roofs failed to cave properly during extraction of coal pillars, and acted as twin 


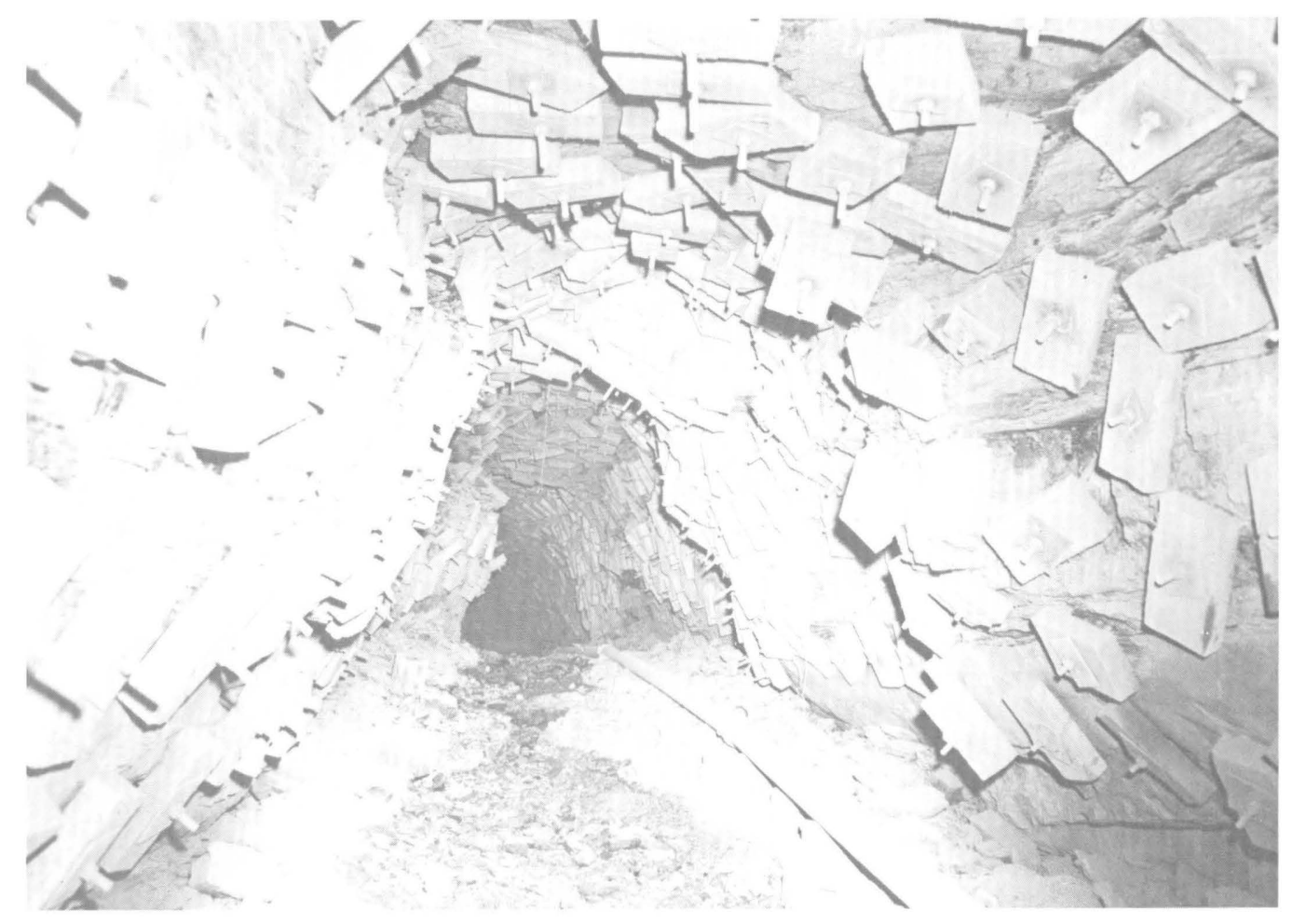

FIGURE 35.--Inversely curved shear fractures in siltstone, right-side manway below 3rd right entry, main slopes, Sunnyside No. 1 Mine, Utah. View northeast, down dip of coal bed. Compressive stresses in siltstone roof caused shear failures along each side of opening; rock between the fractures was forced downward into manway and later was graded over for access, before the bump shown in the frontispiece occurred. Roof bolts are $2.5 \mathrm{~cm}$ (1 in.) in diameter. Photograph by J.C. Witt.

cantilever beams, placing increased stress on the ribs (abutment stresses). In some rare instances, roofs had to be blasted down to forestall possible serious accumulations of stress (Jerome Hernandez, oral commun., 1965). If, however, the ribs were strong, or were strongly supported, some of these massive rock units in the roof failed by shear (referred to as "caving" by miners) under lateral compressive stresses. These failures commonly occurred along curved shear surfaces that flattened in dip downward. Such shear failures happened occasionally in the Sunnyside No. 1 Mine beneath strong siltstone-filled channels in the roof; some of these failures later led to violent bumps in the pillars. For example, the roof of the right-side manway of the Sunnyside No. 1 Mine "caved" for a distance of about $152 \mathrm{~m}(500 \mathrm{ft})$ between $3 \mathrm{~d}$ and $4 \mathrm{th}$ right entries (frontispiece; pl. 1). The failure occurred on opposing convexly curved shear fractures along each side of the manway (fig. 35). Because of the large volume of rock that was forced downward into the openings, the material was graded over rather than removed, so that men and horses could travel, and the new siltstone ribs were strongly roof bolted. Later, part of the caved area bumped violently (frontispiece).
Bumps that follow these initial shear failures in mine roofs occur along curved shear fractures that increase in dip downward into the ribs (fig. 36).

Dome-shaped "drop outs" (roof falls) from the roofs of intersections of mine workings were common deformational features in parts of the Columbia Mine. Although they apparently were caused by local tensile stresses above the widened roof spans at the intersections, the failures probably were initiated by high lateral compressive stresses. The resulting cavities are dome-shaped (fig. 30), probably because the neutral surfaces between zones of tension in the lowermost beds of the roof and zones of compression in the higher beds of the roofs above are arch shaped. Shearing stresses are also initiated along these neutral surfaces. The failures of the roof that produce the drop outs, however, are slow as compared to the massive roof caves along slopes and entries in the Sunnyside No. 1 Mine. The cavity shown in figure 30 formed in the following manner: A crew of miners in the 7 th-eastslope manway of the Columbia Mine noticed that an intersection "began to work" during an afternoon in June 1961. They began to set additional timbers in the intersection, but larger and larger pieces of rock began 
to fall. Miners continued to try to support the intersection through two shift changes, but by the following morning the roof over the intersection had collapsed, leaving a roughly dome-shaped cavity in the roof about $4.5 \mathrm{~m}(15 \mathrm{ft})$ in diameter and about $2.5-3.0 \mathrm{~m}(8-10 \mathrm{ft})$ high. The lowermost beds of the roof consisted of about $1.1 \mathrm{~m}(3.5 \mathrm{ft})$ of siltstone with numerous large horizontal burrows. Above this unit were about $0.6 \mathrm{~m}$ ( $2 \mathrm{ft}$ ) of white, fine-grained sandstone and a meter or two (several feet) of dark- and light-colored, laminated siltstones and claystones. Near the center of the manway, on the downdip side of the dome-shaped cavity, the unit with the horizontal burrows was sheared because of horizontal movements from each side. These movements were caused by lateral compressive stresses. Lateral movement along bedding planes was indicated by slickensides on clayey layers in the unit. A pair of conjugate shear fractures along the south margin of the cavity indicated that vertical compressive stresses in the roof near the rib also were important in inducing the failure of the roof. The actual dropping out of individual pieces of rock, however, probably was the result of local tensile stresses acting upon fragments loosened by compressional failures. Similar conjugate shear fractures, found in the Star Key Mine near Edmonton, Alberta, Canada, where the compressive loading increased to the ultimate

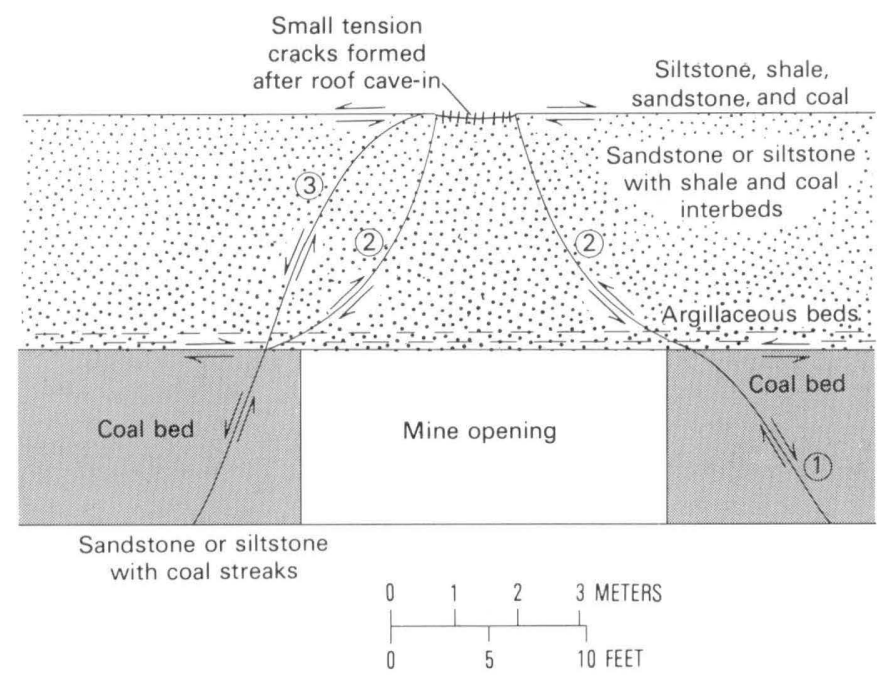

Figure 36.-Diagrammatic section illustrating sequential shear failures around mine opening under massive sandstone or siltstone roof. Initial failure of mine ribs as coal slips beneath roof (1) Compressive roof cave (2) was along curved shear fracture that decreased in dip downward. Final failure (3) was along curved shear fracture that increased in dip downward in upper part, and once in the rib, the fracture surface begins to decrease in dip. Arrows indicate direction of movement. compressive strength of the rocks, resulted in good caving of the roof (probably by tensional collapse) after the coal was removed (Jeremec, 1981, p. 67).

Whenever an opening is made in a rock, the vertical load formerly supported by the removed rock is added to the adjacent rocks. Thus, lateral stresses formerly impeded by rock will deform the rocks above and below the opening and, in addition, will strongly deform the mine ribs. Deformation of mine openings in the northern part of the Sunnyside district, resulting from strong lateral and vertical compressive stresses, produced a narrow zone of reduced stress around mine openings similar to yielded or destressed zones observed elsewhere (fig. 27C; Holland and Thomas, 1954, p. 7-15; Spackeler, 1958, p. 316; Serata and Gloyna, 1960, p. 2981-2986). Within this zone, deformation is primarily the result of local tensile stresses, although some structures resulting from shear stress are visible. Those formed by shear probably are earlier than the tensile deformation. Observed directions of movement along shear planes indicate that the principal stress directions range from vertical in the roof to near $45^{\circ}$ in the ribs. Although differing degrees of adhesion between coal and ribs (or floors) caused different types of deformation in ribs, the orientations of stresses are the same.

That a zone of low-stressed coal exists around coal pillars in the Sunnyside district, owing to previous near-surface failure, is indicated by the results from a series of seismic velocity measurements made underground in the Sunnyside No. 1 Mine by R. A. Black, D. D. Dickey, and J. H. Scott (U.S. Geological Survey, 1963, p. A64). They found that the seismic velocity in the coal varied as the load (overburden) on the coal: highly loaded coal under $465 \mathrm{~m}(1,500 \mathrm{ft})$ of overburden had a velocity of $1,650 \mathrm{~m} / \mathrm{s}(5,400 \mathrm{ft} / \mathrm{s})$; whereas, moderately loaded coal under only about $155 \mathrm{~m}(500 \mathrm{ft})$ of overburden had a velocity of only $1,220 \mathrm{~m} / \mathrm{s}(4,000 \mathrm{ft} / \mathrm{s})$. It was impossible, however, for the investigators to transmit seismic signals through pillars, or into pillars from mine roofs, probably because the pillars fail internally around their margins along shear fractures that extend upward into the roofs. Consistent results were obtained by sending signals through coal in mine floors and along the sides of pillars, rather than through the roofs. Coal with a velocity of $1,220 \mathrm{~m} / \mathrm{s}$ $(4,000 \mathrm{ft} / \mathrm{s})$ was in an area relatively free from bumps, but the coal with a velocity of $1,650 \mathrm{~m} / \mathrm{s}(5,400 \mathrm{ft} / \mathrm{s})$ was in an area with nearly constant bumps, even when mining was not in progress. These in situ measurements yielded results that are within the limits of 24 sonic-velocity measurements done in the laboratory for Scheibner (1979, p. 87) on coal from Sunnyside No. 2 Mine. Here, laboratory tests were done on samples, 
completely removed from the overburden load, so that the velocities would be expected to be lower than the lowest in situ values. The explanation for the relatively high laboratory results is probably that good intact pieces were tested in the laboratory, while the field measurements are average results across fractures and other geological inhomogeneities.

\section{INFLUENCE OF FAULTS}

Faults in the northern part of the Sunnyside district apparently accumulate stresses that result from mining. Several lines of evidence suggest spatial and possibly genetic relationships between faults and bumps, but this relationship is difficult to establish. Most areas are mined rapidly and abandoned; hence, many faults cannot now be observed underground. Other mine openings that cut faults, although open during our investigations, were so strongly supported that we could not see the faults. Because of the extremely complicated patterns of present and past mining operations, many relationships between mine deformation and geologic features are obscured. Furthermore, apparent spatial relationships between bumps and faults may be merely the result of differential loading from an extremely variable thickness of overburden above the coal. Measuring fault movements associated with bumps is difficult because many locations are inaccessible and because it is hard to predict exactly which places may move so that stable markers can be installed and measurements made before movements. Finally, most bumps are accurately located only with seismographs.

Apparent relationships between bumps and faults during mining have been observed in at least two localities in the northern part of the Sunnyside district. When two slopes in the Sunnyside No. 2 Mine were being driven down the dip of the coal bed in 1918 (fig. 37), many bumps occurred as a fault was approached from the footwall side, but only a few bumps occurred after the slopes passed through the faults into the hanging wall side (Watts, 1918). Similarly, in 1951, in the Sunnyside No. 1 Mine, as a rock tunnel was being driven into sandstone to intersect the coal bed about $805 \mathrm{~m}(0.5 \mathrm{mi})$ ahead of the face, many bumps occurred as the fault was approached, but only a few occurred beyond the fault (Peperakis, 1958, p. 984-985). Both of these localities were more than $530 \mathrm{~m}(0.33 \mathrm{mi})$ from the other active mining operations and were considered to be in virgin (unmined) ground (Peperakis, 1958, p. 984).

We made some additional underground and surface observations to study possible spatial and genetic relationships between bumps and movements along

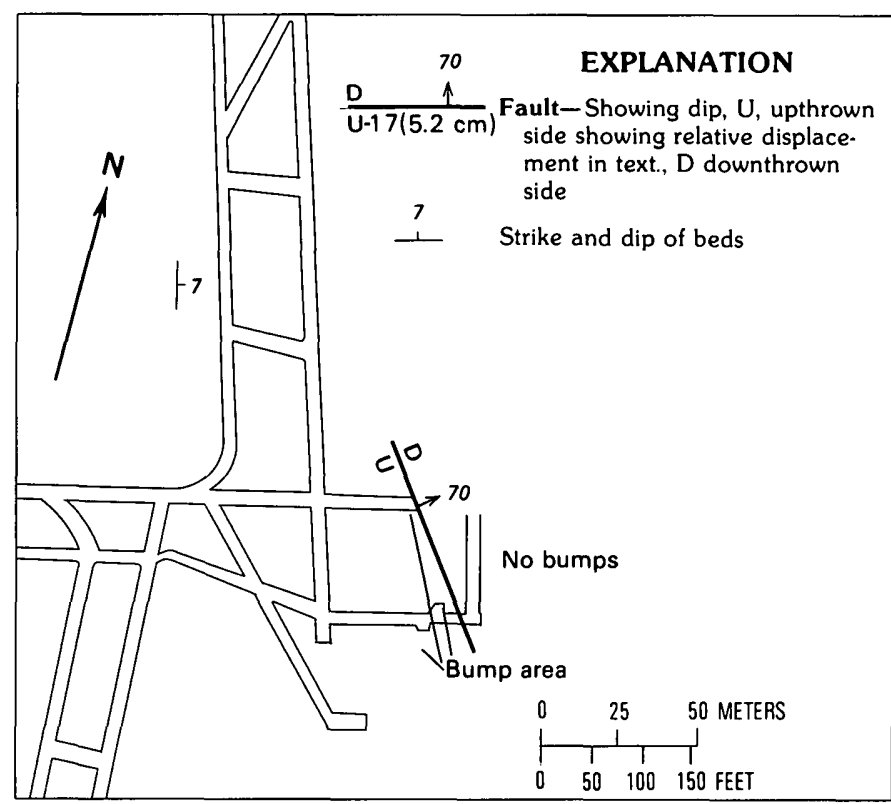

FIGURE 37.-Map showing relation of fault to bumping and nonbumping areas in part of the Sunnyside No. 2 Mine, Utah. Slopes were being driven down the dip of the coal bed; violent bumps were encountered as the fault was approached. After going around the fault in the southern slope, no further bumps were encountered. Modified from Watts (1918, fig. 2).

the Sunnyside fault zone (pls. 1, 3). Index marks were scribed in July 1960 on the ends of five roof bolts in an old air return (Sunnyside No. 1 Mine) that crossed several small faults in the upthrown (northeastern) side of the Sunnyside fault zone (pl. 1). After a violent bump in the No. 1 Mine on May 6, 1961, we remeasured the distances between the index marks. Distances between all the marks had changed; the accumulative distance shortened across the measured span of three faults by $0.82 \mathrm{~cm}(0.324 \mathrm{in}$.$) , as indicated$ in figure 38 . These facts imply that movement occurred within the fault zone, probably during the bump.

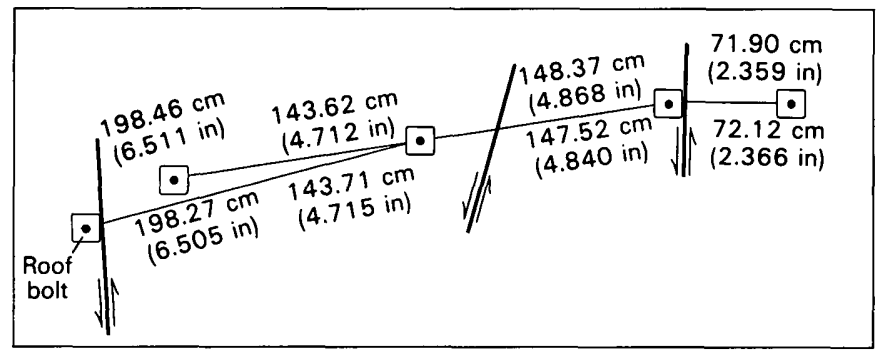

FIGURE 38.-Distances measured between roof bolts before and after violent bump in Sunnyside No. 1 Mine, May 6, 1961. Inclined section near roof of northwest side of left-side air return, across small faults in upthrown side of Sunnyside fault zone. Original distances are above the measured lines; distances after bump are below lines. Arrows indicate directions of movements along faults. 
We also measured movements, which probably occurred during bumps, on the Sunnyside fault zone at the surface. Rails on the haulage road from the Sunnyside No. 1 Mine portal to the car dump frequently were bent horizontally and vertically where they cross the fault zone (fig. 39). We determined levels and positions of marked points on the rails in July 1961. A bump occurred at very shallow depth on the following day along a manway into the Sunnyside No. 3 Mine about $7.6 \mathrm{~m}(25 \mathrm{ft})$ beneath the haulage road. We remeasured the levels and positions of the marked points on the rail on the day after the bump and found horizontal movements of as much as $3.05 \mathrm{~cm}(0.1 \mathrm{ft})$ and vertical movements of $36.58 \mathrm{~cm}$ (1.20 ft) (fig. 40). Although bending of the track is attributed by miners to subsidence of loose material into the manway, most bending takes place across a broad area where the rails cross the fault zone (Osterwald and Dunrud, 1965, p. 171) and is not restricted to the narrower area above the manway portal. The measured upward movements of points on the rail (fig. 40) probably would not have resulted from subsidence. Furthermore, after the bump no loose material or evidence of subsidence could be seen in the manway, indicating that much of the bending resulted from lateral fault movement and not from vertical subsidence.

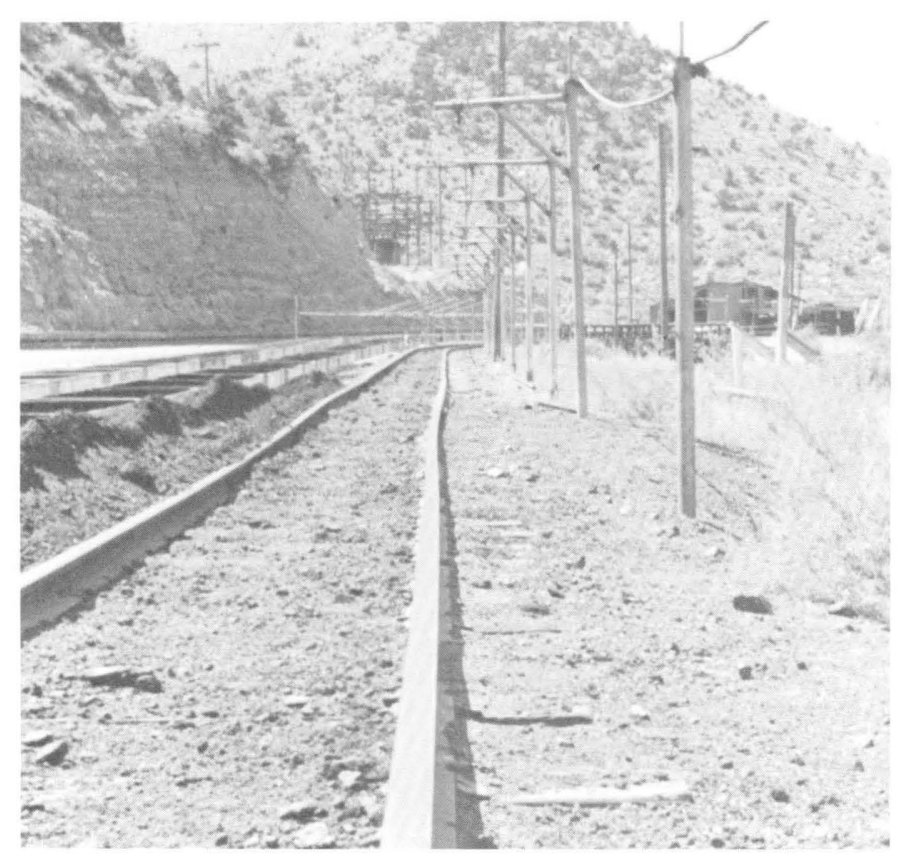

Figure 39.-View southwestward along bent rails on haulage road from Sunnyside No. 1 Mine portal to car dump. Bent portion is across Sunnyside fault zone and over the manway portal to Sunnyside No. 3 Mine. Bent track is on about $3 \mathrm{~m}(10 \mathrm{ft})$ of artificial fill. Track at low level on left with empty mine cars was repaired before picture was taken. Photograph taken in October 1960 , before the measurements shown in figure 40 were made.

\section{SUBSIDENGE OF THE LAND SURFACE}

Collapse of roof rocks into mined-out areas is an integral part of the normal mining cycle in many western coal mines. Normally, the collapse of mine roofs is planned to relieve concentrations of high stress that otherwise would build up in pillars and working faces that are adjacent to mined-out spaces. In theory, an uncollapsed roof transfers stress into the margins of the worked-out areas (abutment zones) and thus causes violent bumps in actively mined parts of these marginal abutment zones. For this reason efficient mining plans for room-and-pillar mines include the removal or destruction of all pillars remaining in worked-out areas. Longwall mining plans include immediate collapse of the roof rocks behind the faces as soon as roof supports are advanced to follow the faces. In the northern part of the Sunnyside district, modern room-and-pillar and longwall methods have been used since 1961 to remove as much as 90 percent of the available coal, excluding chain pillars and barrier pillars (John Peperakis, Kaiser Steel Corp., oral commun., 1965). This high percentage of coal extraction indicates that the collapse of roof rocks into mined-out areas was at least locally effective.

Collapse of roof rocks into worked-out areas had little impact upon use of the surface in the Sunnyside district at the time our work was done, because only lowlands outside the mining areas are inhabited. Some surface effects in the district, however, were spectacular and yielded valuable information on the rate and extent of subsidence as well as demonstrating the influence of geologic features on subsidence. Subsidence probably is much more prevalent in the district than we have shown on maps of the surface (Osterwald, 1962a, Osterwald and others, 1969; Dunrud and Barnes, 1972); fortunately, the surface above the mines is uninhabited and only rarely visited by people.

Caving of the roof immediately after mining, which is desired by miners for reasons of economy and safety, is not always attainable. For example, a thick channel sandstone in the northern part of the Sunnyside No. 1 Mine, which overlies less than $2 \mathrm{~m}$ (a few feet) of rider coal and less than $0.6 \mathrm{~m}$ (a foot or two) of brittle siltstone (Osterwald and Dunrud, 1965, p. 172-173), makes a good roof in the mine and provides a solid anchor for roof bolts during development work. During extraction of pillars, however, this sandstone did not cave (T. R. McCourt, mine superintendent, oral commun., 1964). Violent bumps and poor roof conditions were thereby created in nearby room-and-pillar works, endangering lives and mining equipment. Similar conditions also are created in other areas when the roof does not cave immediately for other reasons. 


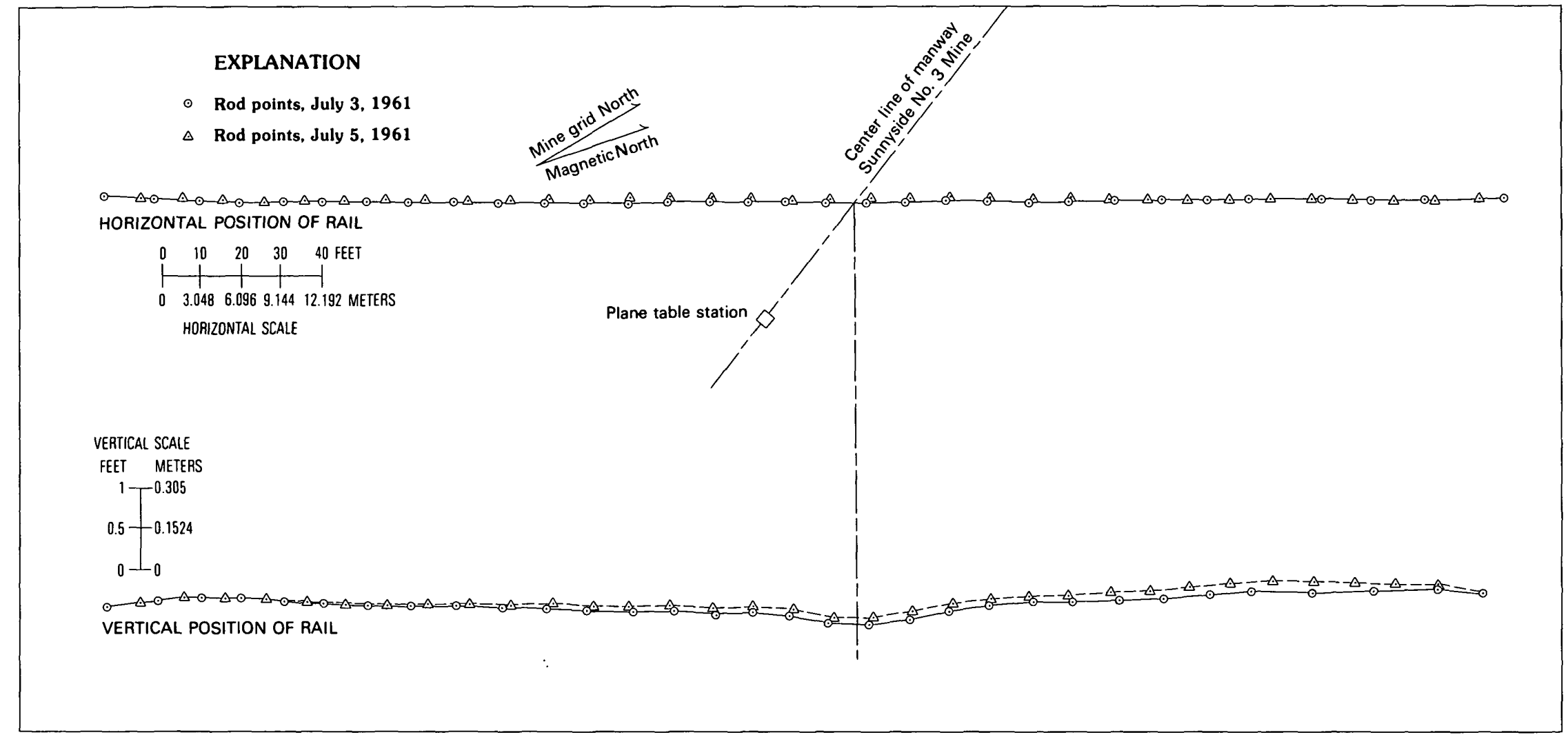

FIGURE 40.-Horizontal and vertical changes between marked points along rail haulage road from Sunnyside No. 1 Mine portal to car dump, July 3 and 5, 1961. Solid line is for July 3 measurements; dashed line is for July 5 measurements. Both solid and dashed lines represent rail positions. 
Major sandstone units above the Sunnyside coal bed, of which the Castlegate Sandstone and the Bluecastle Member of the Price River Formation (Osterwald and others, 1981, p. 19-22) are the thickest and most widespread, also influence subsidence. A common assumption among miners that roofs would not cave through the Castlegate (which is as much as $92 \mathrm{~m}$ (300 $\mathrm{ft}$ ) thick) and the Bluecastle (which varies between 3 and $92 \mathrm{~m}$ (10 and $300 \mathrm{ft}$ ) thick) was incorrect. Caving to the surface through the Castlegate and Bluecastle locally is extensive, cutting through as much as $730 \mathrm{~m}$ $(2,400 \mathrm{ft})$ of overlying rocks and producing some spectacular subsidence features (figs. 41, 42). Most subsidence features at the surface follow bedrock joints and faults. For this reason subsidence extends through the Castlegate, the Bluecastle, the Colton Formation, and other competent rock units wherever joints and faults are present, especially where lateral restraint is low. During 1959, subsidence features appeared at the surface of West Ridge above part of the Sunnyside No. 1 Mine about 20 years after mining was completed in that area. During 1977, a prominent graben appeared in the Colton Formation near the top of the east side of West Ridge more than 20 years after mining beneath the graben was completed.
Most of the known surface subsidence features in the Sunnyside district are various types of cracks. Some of the cracks show actual vertical displacement of the land surface, others are simple tension cracks (crevices) in which the opposing sides are pulled directly apart, and still others are pushed together in compression (fig. 43). The first two types of cracks correspond to the steps and cracks of Brauner (1973, p. 3); the third type corresponds to pressure ridges in Arctic ice fields. All types of surface cracks either follow preexisting joint and fault planes in bedrock or are arranged in belts of en echelon breaks in surficial deposits.

We do not know whether a gradual, more uniform lowering of the land surface accompanies the spectacular surface cracking in the district. Such lowering is common in many mining areas of the world, producing dish-shaped subsidence sinks (Grond, 1951, p. 52-53). We made no measurements at Sunnyside to determine if such a subsidence bowl exists, except along the Sunnyside fault zone, but no visible evidence indicates that it does. Complete removal of coal from such large areas, however, probably would result eventually in some form of general subsidence.

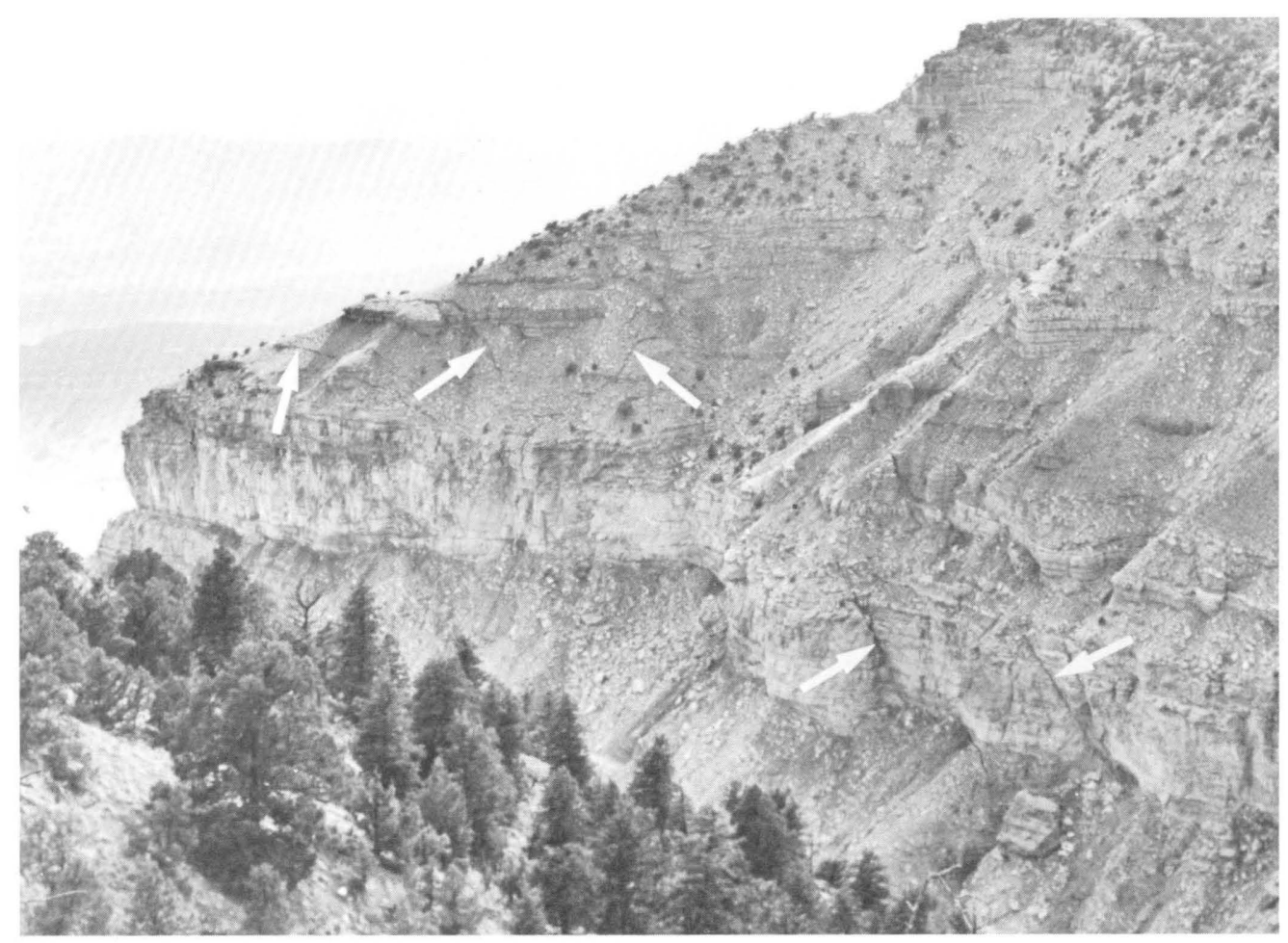

Figure 41.- Subsidence cracks (arrows) in Lila Canyon above the Book Cliffs Mine (fig. 2) (southern part of the Sunnyside district, Utah) extending through the 61-m- (200-ft-) thick Castlegate Sandstone. Photograph taken in 1959, soon after pillar extraction in the mine was started. 


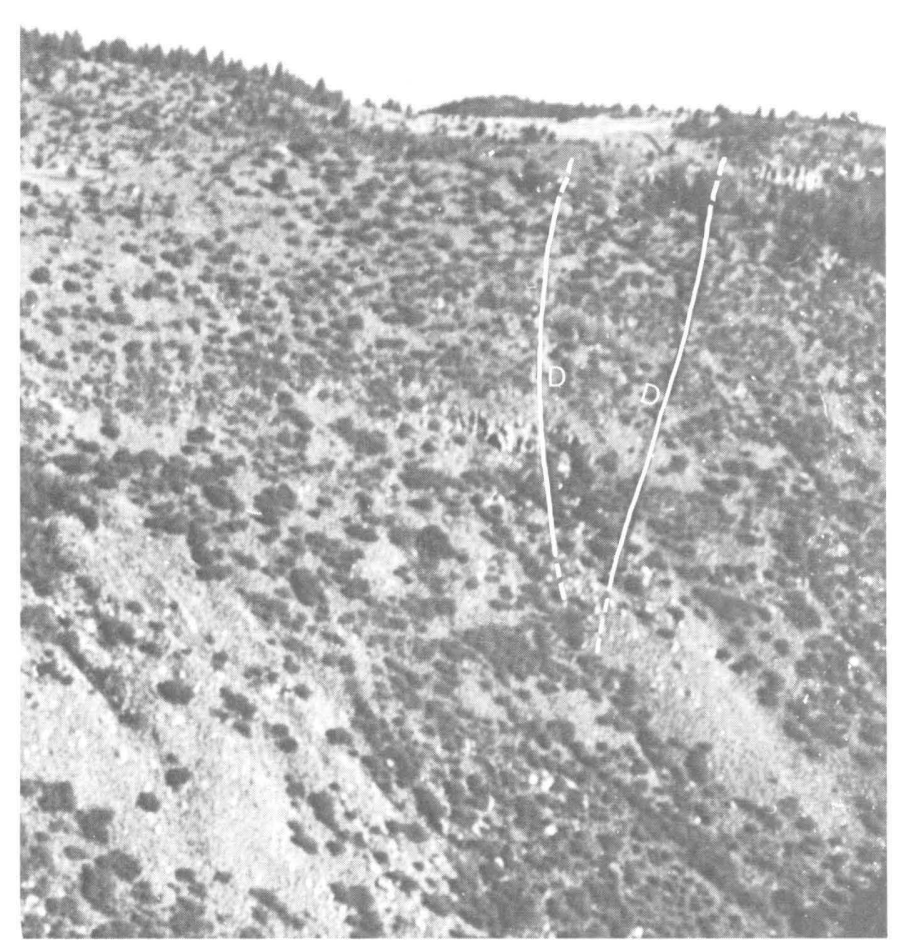

Figure 42.-Oblique aerial photograph showing graben in Colton Formation on east side and top of West Ridge, $730 \mathrm{~m}(2,400 \mathrm{ft})$ above Sunnyside No. 1 Mine. Subsidence apparently was related to an unmined series of chain pillars of coal along a diagonal entry (under left side of graben) adjacent to a large area from which coal pillars had been removed (Osterwald, 1962a, sheet 2). Surface fractures shown by heavy lines; D indicates downthrown side. Photograph taken June 1977.

A very spectacular zone of subsidence features appeared in the summer of 1959 along the trace of the Sunnyside fault zone, near the south end of West Ridge (figs. 2, 44; pl. 1). Individual breaks in this zone had a zigzag surface trace, paralleling bedrock joints, although the cracks themselves were in Pleistocene colluvium which is as much as $2 \mathrm{~m}$ (6 ft) thick. Displacement of the land surface amounted to as much

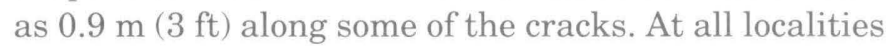
the surface was displaced downward to the northeast, opposite to the direction of stratigraphic separation on the Sunnyside fault zone. Maximum overburden above the coal is about $370 \mathrm{~m}(1,200 \mathrm{ft})$ along this zone of subsidence cracks. Caving in the overburden extended upward through both the Castlegate Sandstone and the Bluecastle Sandstone Member of the Price River Formation. By the fall of 1977, however, little evidence of subsidence could be found at this locality. Nearly all the cracks were sealed by downhill movement of surficial material, and all but a few displacements were obliterated by cattle and horse tracks.

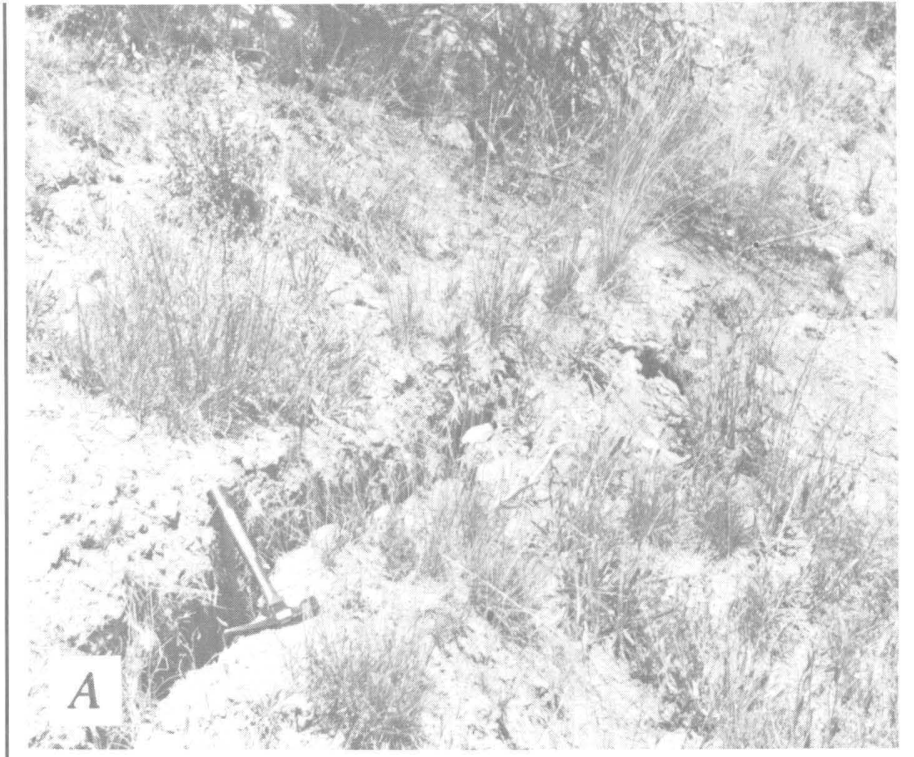

$A$, Tension crack in colluvium $(0.9-1.5 \mathrm{~m}(3-5 \mathrm{ft})$ thick) along west side of Whitmore Canyon. Colluvium on right side of crack (east) has dropped about $20 \mathrm{~cm}$ (8 in.). Hammer handle is about $30 \mathrm{~cm}$ (1 ft) long.

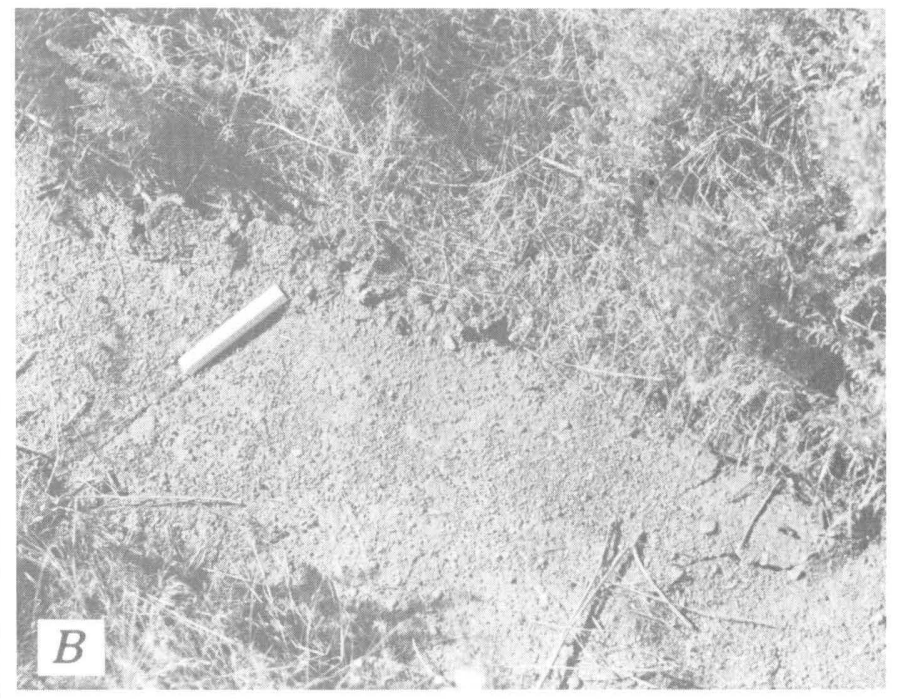

$B$, Small compression crack or pressure ridge in alluvium (along top margin of bare alluvium) following east-trending bedrock fracture at mouth of Schoolhouse Canyon, near Sunnyside No. 1 Mine portal, Utah. Scale indicated by 15.2 -cm (6-in.) rule.

Figure 43.-SUBSIDENCE CRACKS IN SURFICIAL MATERIALS ABOVE THE SUNNYSIDE NO. 1 MINE IN 1959

The land surface slopes steeply eastward from the subsidence zones on West Ridge into Whitmore Canyon, the floor of which is about $185 \mathrm{~m}$ (600 ft) below 


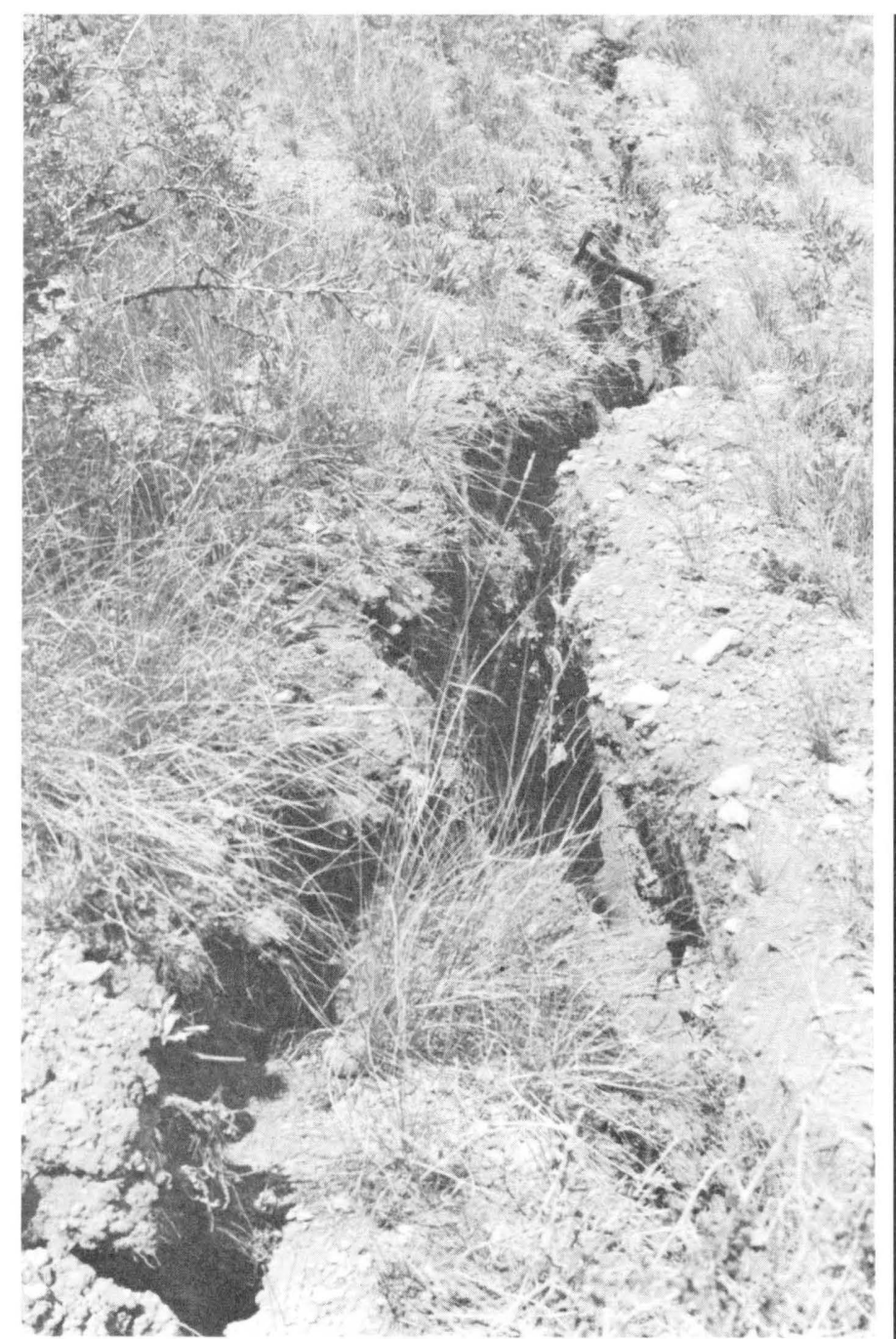

Figure 44.-Subsidence cracks in colluvium, 0.9-1.5 m (3-5 ft) thick, overlying Bluecastle Sandstone Member of Price River Formation along west side of Whitmore Canyon, $610 \mathrm{~m}(2,000 \mathrm{ft})$ northwest of portal of Sunnyside No. 1 Mine, Utah. Photograph taken in 1959. Hammer handle is about $30 \mathrm{~cm}$ (1 ft) long.

the cracked zone. Dipping gently northeastward, stratigraphic units from the Castlegate to the Flagstaff Limestone (Paleocene and Eocene) crop out on the slope or are covered by only 1 or $2 \mathrm{~m}$ (several feet) of colluvium. When the downward gravitational force on individual joints or fault-bounded blocks in a rock mass exceeds the friction on the joints or faults, the entire mass will fail (Evans, 1941, p. 475-477). Horizontal forces (producing lateral restraint against collapse) that act upon the rock mass will impede the gravitational collapse, but, if the horizontal force (or lateral restraint) is reduced, the mass will collapse. The orientation of the ground slope and the dip of the beds on West Ridge allow gravity to considerably reduce the

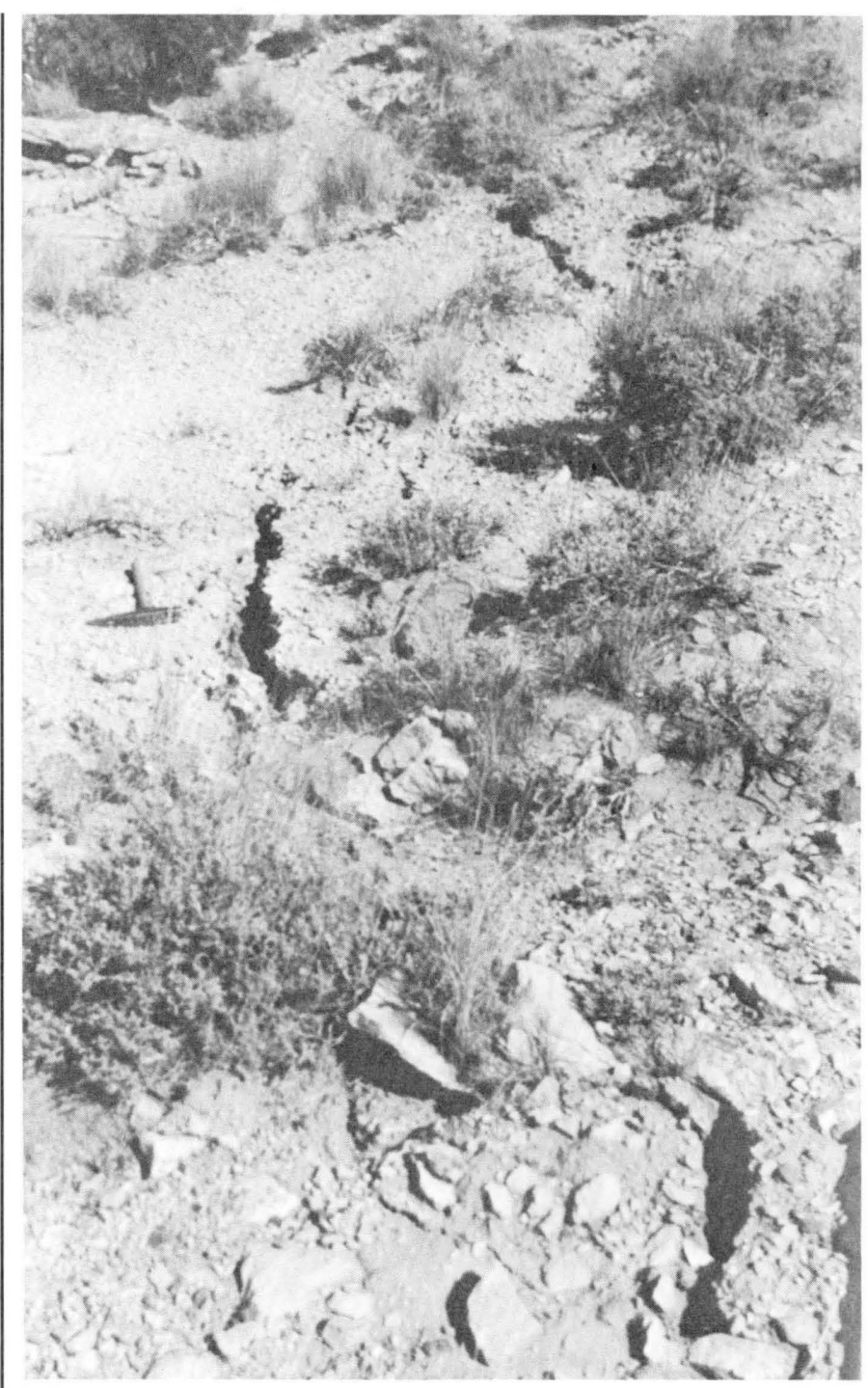

Figure 45.-View north of zigzag fractures on top of stripped surface of Castlegate Sandstone, at top of cliff above mouth of Schoolhouse Canyon (fig. 2). Cracks follow bedrock joints in underlying Castlegate. Scale indicated by hammer handle about $30 \mathrm{~cm}(1 \mathrm{ft})$ long.

lateral restraint, in a nearly east-west direction, on the northwest-trending faults and joints in rocks above the coal bed. This reduction in lateral restraint probably explains why spectacular subsidence features are found along Whitmore Canyon and why such features are not known at other localities in the northern part of the district.

Many of the cracks (crevasses) in this zone stood open, the walls having been pulled apart as much as $0.6 \mathrm{~m}$ (a foot or two) by tensional stresses. These cracks were a pronounced hazard to men and animals until they closed; fortunately, they were in a remote area where few people were allowed. The cracks were very deep, and some emitted air and gases that smelled like mine atmosphere. 


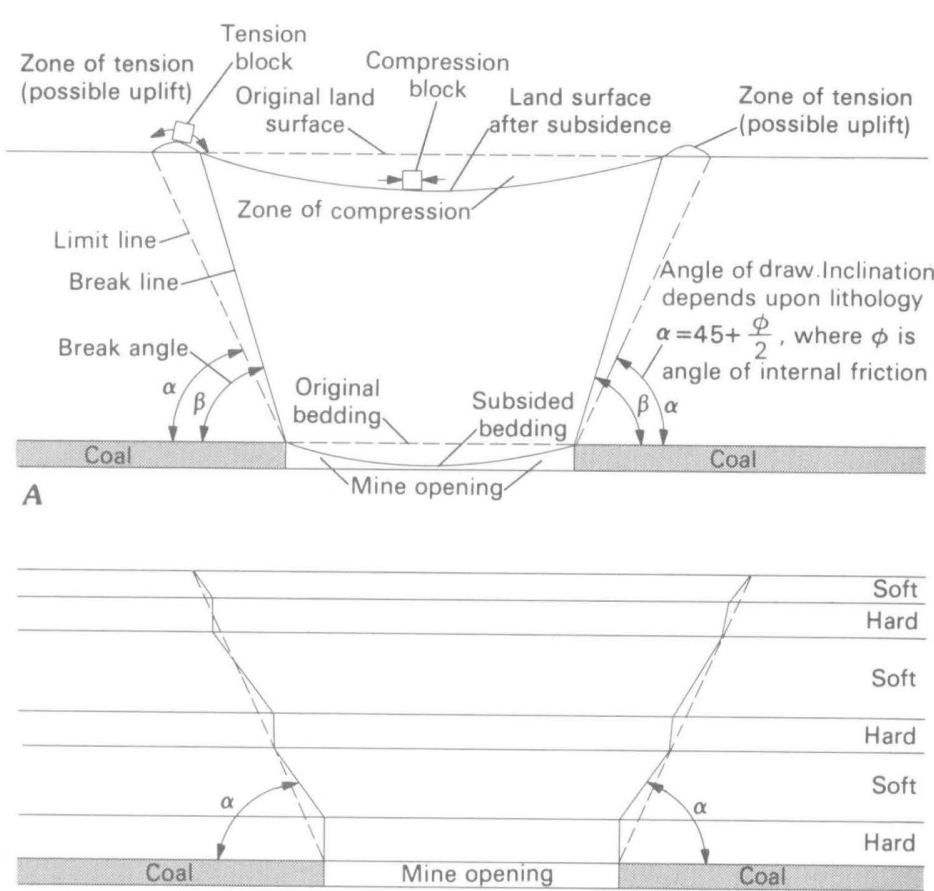

B

FIGURE 46.-Diagrammatic sketches showing effects of subsidence into mine openings (modified from Isaacson, 1958, figs. 53, 54). $A$, zones of tension and compression produced in structures at the land surface, angle of draw $(\alpha)$, break angle $(\beta)$, limit line, and break line; $B$, deflections of limit line (dashed) and changes in angle of draw $(\alpha)$ through alternating hard and soft rock layers. Dashed limit line is an estimate of an idealized smooth surface.

Another belt of cracks (crevasses) extended along the east side of Whitmore Canyon, at or slightly above the top of the Castlegate Sandstone. Individual crevasses in the belt dipped steeply, and the belt was nearly parallel to the trend of the canyon. Individual crevasses followed directions of jointing in the Castlegate, so that the surface traces zigzagged (fig. 45). Most of these crevasses were open, some as much as $0.9 \mathrm{~m}$ ( $3 \mathrm{ft})$ wide, and a few also emitted gas and odors smelling like mine atmosphere. This belt of crevasses (cracks) persisted for more than 10 years, although some individual crevasses closed and others opened at various times (fig. 45).

In a former residential area of the town of Sunnyside, near the mouth of Schoolhouse Canyon (fig. 2), a few small pressure ridges in alluvium appeared in 1958 (fig. 43B), probably because of local compressive stress produced at the surface at points where vertical subsidence was at a maximum (fig. 46). Horizontal movement of the surface in some areas is also indicated by en echelon systems of cracks (fig. 47), resulting from horizontal shear couples produced by differential subsidence over old pillars. After mining ceased (Oster-

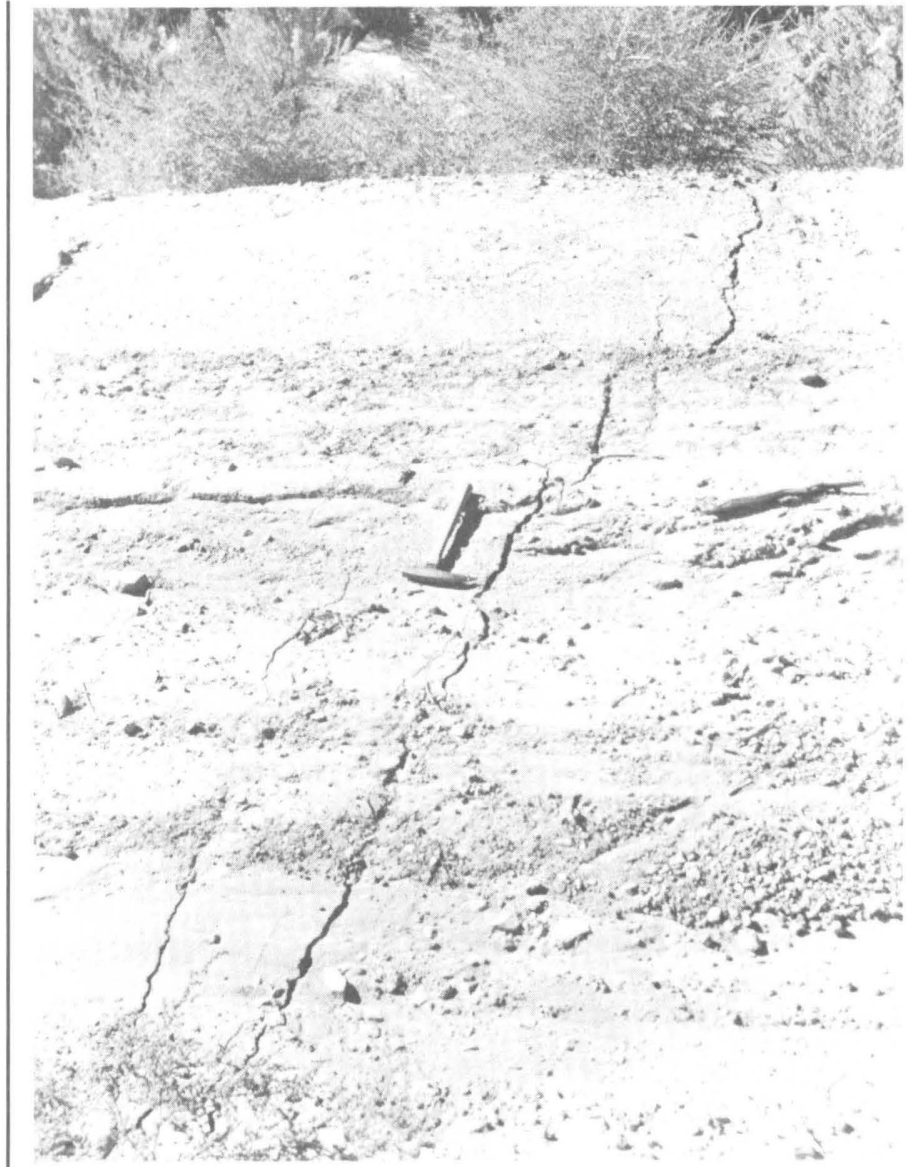

Figure 47.-View north of cracks in en echelon arrangement cutting road near mouth of Schoolhouse Canyon, near portal of Sunnyside No. 1 Mine, Utah. Hammer handle is about $30 \mathrm{~cm}(1 \mathrm{ft})$ long.

wald, 1962a, sheet 2), in the hope they might prevent subsidence, many pillars were left beneath the former town site near Schoolhouse Canyon and beneath Grassy Trail Creek (fig. 2; pl. 5). The practice of leaving coal pillars in the mine to support and protect surface structures, although widely accepted in the Eastern United States (Vandale, 1967, p. 87-88), may be questionable in some circumstances. Much coal is wasted by the practice, and detailed surveying in the Somerset district, Colorado, indicates that surface movement over some remaining barrier pillars may exceed that over mined-out spaces (Dunrud, 1976, p. 22-23).

The subsidence crevasses along both sides of Whitmore Canyon were reexamined by Barton K. Barnes (U.S. Geological Survey) in 1967. He found that many of the original cracks paralleling the northwesttrending joints along the west side of the canyon (Osterwald, 1962a, sheet 2) had closed and that some new ones had opened. Most of the new cracks followed the east-northeast joints in the bedrock. 


\section{STRENGTH, STRESS-STRAIN CHARACTERISTICS, AND CHEMICAL VARIATIONS IN COAL FROM THE SUNNYSIDE COAL BED}

In order to evaluate the response of coal in the Sunnyside coal bed to changes in stress (both natural stresses and those induced by mining), the strengths of selected large coal blocks from the Sunnyside Nos. 1 and 3 Mines were determined. Blocks from both mines were selected from coal layers that appeared to be uniform megascopically, as a means of reducing the effects of inhomogeneity on the test results. Variations in chemistry among coal cores from the Sunnyside No. 3 Mine that appeared to respond differently to stress were also examined. Because of the almost tenfold differences in triaxial strengths of cores from the Sunnyside No. 1 Mine tested at the same confining (lateral) stress (table 1), the results of all these tests probably are of only limited use in directly providing strength parameters for use in mine design. The authors concur with the conclusions of Bieniawski (1968) that laboratory tests on coal specimens of any size can be used only for comparative purposes because the strengths of most coals are determined by extent and distribution of fracturing. The test results, however, did reveal several important factors related to the behavior of Sunnyside coal under stress, as described on the following pages. One of the most important of these factors involves chemical variations in the coal that either influence the failure strengths or result from molecular reconstitution in response to stress changes. Some cores cut from the same coal block varied widely in failure strengths. These factors provided a basis for understanding some of the failure mechanisms of coal under varying conditions and, hence, indirectly should help mining engineers to design safe, economical mining plans by providing insights into the range of strengths to be expected. The factors may also provide a basis for comparing the strength of Sunnyside coal with that of coals from other regions. Similarly, measuring some of the chemical constituents (organic molecular groups) of coals whose strength characteristics are unknown may help explain their behavior under various ranges of stress conditions.

The response of coal to stress is unusual among rocks. Coal stores large amounts of strain energy when stressed (Greenwald and others, 1939, p. 8-9), and, in addition, the failure strength may depend in part upon chemical composition (Hobbs, 1964, p. 216). During laboratory testing of Sunnyside coal we obtained several anomalous results, probably because of these varying characteristics. These anomalous results included erratic-appearing excursions on several of the stress-strain curves, and in at least one core, lateral strain was reduced as axial stress was increased (fig. 50; table 1). The reduced lateral strain probably resulted from either closing of internal cracks or chemical changes in the coal. Samples tested in laboratories probably behave in a manner similar to the $1.5-\mathrm{m}(5-\mathrm{ft})$-square pillars of Pittsburgh coal that were tested in place by the U.S. Bureau of Mines (Greenwald and others, 1939). These pillars expanded upward as the roof shales were removed manually with a pick. After expanding, twice the overburden stress was required to jack them back to their original dimensions (Greenwald and others, 1939, p. 15-16). In addition, many of the laboratory samples produced miniature coal mine bumps by failing explosively with loud reports.

\section{TERMINOLOGY}

Some of the terminology in common use for strength testing of rocks and other materials is confusing because several terms are applied by different workers to identical concepts and features. Although no attempt was made to include a complete listing of terms used in testing in our glossary, some of the terms that we have used are defined. We have attempted to be consistent in usage of them in the report, even though other works are cited in which they are used differently.

Compressive strength refers to the amount of applied load per unit area that is required to crush a specimen, usually a circular cylinder (a core) or a cube. If no restraint or force is applied to the outer surface of a cylindrical core or to a cube when it is being tested, the test is said to be uniaxial or unconfined. The load per unit area applied to the top and bottom of the specimen is referred to as axial or longitudinal stress, or sometimes simply as compressive stress. Tests that include a force per unit area applied to the outside of a cylindrical core, as well as axially, are referred to as triaxial compressive tests although only two stresses actually are applied. The stress applied to the sides of the cylinder is referred to as lateral or confining stress. In triaxial testing the force per unit area on the ends of the cylinder may be termed axial or longitudinal stress. The axial stress at which a specimen tested triaxially fails is termed the triaxial or confined compressive strength. In the discussions that follow the terms "unconfined compressive test" and "triaxial compressive test" are used. Stresses in triaxial compressive testing are referred to as axial stress and confining stress. The stress at which a sample tested in unconfined compression fails is referred to as the unconfined 
TABLE 1.-Triaxial compressive test results by U.S. Geological Survey from NX drill cores of coal from Sunnyside No. 1 Mine, Utah [Analysts: B.K. Barnes, G.S. Erickson, R.A. Speirer, R.A. Farrow, and T.C. Nichols, Jr. Cores air dried to remove excess water from drilling and machining. Core number with N indicates long axis of core normal to bedding; $P$, indicates long axis parallel to bedding. Leaders (-.-) indicate no data available). lbf/in ${ }^{2}$ equivalent to psi (pounds per squareinch) used in common mining terminology.]

\section{UNMACHINED NX DRILL CORES}

\begin{tabular}{|c|c|c|c|c|c|c|c|c|c|c|c|c|c|}
\hline \multirow{3}{*}{ Core No. } & \multirow{2}{*}{\multicolumn{3}{|c|}{$\begin{array}{c}\text { Confining (lateral) } \\
\text { stress }\end{array}$}} & \multirow{2}{*}{\multicolumn{3}{|c|}{$\begin{array}{l}\text { Axial (longitudinal) } \\
\text { stress at failure }\end{array}$}} & \multirow{3}{*}{$\begin{array}{c}\begin{array}{c}\text { Lateral } \\
\text { strain }\end{array} \\
(\mu \mathrm{m} / \mathrm{m})\end{array}$} & \multirow{3}{*}{$\begin{array}{c}\begin{array}{c}\text { Axial } \\
\text { (longi- } \\
\text { tudinal) } \\
\text { strain }\end{array} \\
(\mu \mathrm{m} / \mathrm{m})\end{array}$} & \multirow{3}{*}{$\begin{array}{l}\text { Poisson's } \\
\text { ratio }\end{array}$} & \multicolumn{2}{|c|}{ Axial (longitudianl) } & \multirow{3}{*}{$\begin{array}{c}\text { Duration } \\
\text { of } \\
\text { loading } \\
\text { time }\end{array}$} & \multirow{3}{*}{$\begin{array}{c}\text { Loading } \\
\text { rate } \\
\text { axial } \\
\text { stress } \\
{ }^{2}\left(\mathrm{~s} / \mathrm{kg} / \mathrm{cm}^{2}\right)\end{array}$} \\
\hline & & & & & & & & & & \multirow{2}{*}{$\begin{array}{c}\text { Tangent } \\
\text { modulus of } \\
\text { elasticity }\end{array}$} & \multirow{2}{*}{ 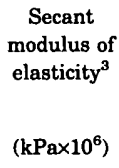 } & & \\
\hline & ${ }^{1} \mathrm{lbf} / \mathrm{in}^{2}$ & $\mathrm{~kg} / \mathrm{cm}^{2}$ & $\mathrm{kPa}$ & ${ }^{1} \mathrm{lbf} / \mathrm{in}^{2}$ & ${ }^{2} \mathrm{~kg} / \mathrm{cm}^{2}$ & $\mathrm{kPa}$ & & & & & & & \\
\hline $10 \mathrm{~N}$ & & & & & & & & & & & & 66.5 & $6 / 70.307$ \\
\hline 1st cycle ........ & 0 & 0 & -- & 865 & 60.8 & 5,964 & $+1,630$ & $-6,864$ & 0.237 & -- & 0.883 & $\cdots$ & -- \\
\hline $2 \mathrm{~d}$ cycle ......... & 0 & 0 & -- & 2,306 & 162 & 1,590 & ${ }^{4}+2,081$ & ${ }^{4}-7,796$ & .267 & 3.327 & 1.275 & $\ldots$ & $\left({ }^{6}\right)$ \\
\hline $13 \mathrm{~N}$ & 0 & 0 & -- & 1,209 & 85.0 & 8,332 & $+4,652$ & $-2,275$ & .277 & 3.294 & 3.179 & $\cdots$ & -- \\
\hline \multicolumn{14}{|l|}{$15 \mathrm{~N}$} \\
\hline 1st cycle ........ & 0 & 0 & $\cdots$ & 1,441 & 101 & 9,937 & $+1,876$ & $-3,891$ & .482 & 2.585 & 2.481 & -- & $\left({ }^{6}\right)$ \\
\hline 2d cycle ......... & 0 & 0 & $\cdots$ & 3,600 & 253 & 2,482 & $+2,837$ & $-4,802$ & .591 & 5.593 & 5.363 & 140 & -- \\
\hline \multicolumn{14}{|l|}{$16 \mathrm{~N}$} \\
\hline 1st cycle ........ & 0 & 0 & -- & 1,440 & 101 & 9,929 & $+1,180$ & $-4,675$ & .252 & 2.039 & 2.060 & 39 & 7/70.307 \\
\hline $2 \mathrm{~d}$ cycle .......... & 0 & 0 & $\cdots$ & 2,900 & 204 & 19,996 & $+2,267$ & $-6,998$ & .324 & 5.935 & 3.123 & 53 & -- \\
\hline $7 \mathrm{~N}$ & 200 & 14.1 & 1,379 & 6,486 & 456 & 44,721 & ${ }^{4}+2,370$ & ${ }^{4}-8 ; 449$ & .281 & 5.418 & 5.369 & 192 & $\left({ }^{6}\right)$ \\
\hline $8 \mathrm{~N}$ & 200 & 14.1 & 1,379 & 6,014 & 423 & 41,467 & ${ }^{4}+2,719$ & ${ }^{4}-10,525$ & .258 & 3.999 & 4.060 & 154 & $\left({ }^{6}\right)$ \\
\hline $11 N$ & 200 & 14.1 & 1,379 & ${ }^{5} 12,594$ & 886 & 86,836 & $+2,880$ & ${ }^{4}-12,609$ & .228 & 4.464 & 4.640 & 220 & $\left({ }^{6}\right)$ \\
\hline $14 \mathrm{~N}$ & 200 & 14.1 & 1,379 & 5,057 & 356 & 34,868 & $+5,829$ & ${ }^{4}-7,343$ & .794 & 9.699 & 3.771 & 240 & $\left({ }^{6}\right)$ \\
\hline $17 \mathrm{P}$ & 200 & 14.1 & 1,379 & 7,343 & 516 & 50,630 & ${ }^{4}+1,963$ & ${ }^{4}-6,932$. & .283 & 6.803 & 6.477 & 166 & $\left({ }^{6}\right)$ \\
\hline \multicolumn{14}{|l|}{$5 \mathrm{~N}$} \\
\hline 1st cycle ........ & 1,000 & 70.3 & 6,895 & 4,714 & 331 & 32,503 & +458 & $-7,251$ & .063 & -- & 4.483 & $\therefore-$ & $\left({ }^{6}\right)$ \\
\hline $2 \mathrm{~d}$ cycle ......... & 1,000 & 70.3 & 6,895 & 4,714 & 331 & 32,503 & $+1,256$ & $-9,591$ & .131 & -- & 3.389 & $\cdots$ & do. \\
\hline $3 \mathrm{~d}$ cycle ......... & 1,000 & 70.3 & 6,895 & 4,714 & 331 & 32,503 & +767 & $-7,296$ & .105 & -- & 4.452 & $\cdots$ & do. \\
\hline 4th cycle........ & 1,000 & 70.3 & 6,895 & 6,714 & 472 & 46,293 & $+1,913$ & $-10,349$ & .185 & -- & 4.273 & $\ldots$ & do. \\
\hline 5 th cycle........ & 1,000 & 70.3 & 6,895 & 8,143 & 573 & 56,146 & $+2,981$ & $-12,881$ & .231 & -- & 4.359 & $\cdots$ & do. \\
\hline 6 th cycle........ & 1,000 & 70.3 & 6,895 & 9,571 & 673 & 65,992 & $+4,095$ & $-14,913$ & .275 & $\cdots$ & 4.426 & $\cdots$ & do. \\
\hline 7th cycle......... & 1,000 & 70.3 & 6,895 & 11,000 & 773 & 75,845 & $+5,240$ & $-16,631$ & .315 & -- & 4.560 & ... & do. \\
\hline 8th cycle........ & 1,000 & 70.3 & 6,895 & 12,000 & 844 & 82,740 & ${ }^{4}+5,592$ & ${ }^{4}-16,901$ & .331 & -- & 4.573 & --- & $\left({ }^{6}\right)$ \\
\hline $\begin{array}{c}4 \mathrm{~N} \text { (creep } \\
\text { test) } \ldots \ldots \ldots \ldots . . . . . .\end{array}$ & & & & & & & & & & & & & $\left({ }^{6}\right)$ \\
\hline 1st cycle ......... & 1,000 & 70.3 & 6,895 & 6,714 & 472 & 46,293 & +141 & $-8,891$ & .016 & 4.793 & 4.413 & 77 & $151 \mathrm{~s}$ to \\
\hline $2 \mathrm{~d}$ cycle .......... & 1,000 & 70.3 & 6,895 & 9,571 & 673 & 65,992 & $+2,850$ & $-15,372$ & .185 & 5.092 & -- & 109 & $154 \mathrm{~s}$ to \\
\hline $3 d$ cycle ......... & 1,000 & 70.3 & 6,895 & 11,000 & 773 & 75,845 & $+2,769$ & ${ }^{4}-14,476$ & .191 & 3.878 & 3.236 & 137 & $\left({ }^{6}\right)$ \\
\hline $12 \mathrm{~N}$ & 1,000 & 70.3 & 6,895 & 10,429 & 733 & 71,907 & ${ }^{4}+4,280$ & ${ }^{4}-15,667$ & .273 & 5.158 & 4.230 & 120 & $\left({ }^{6}\right)$ \\
\hline $20 \mathrm{~N}$ & 5,000 & 351.5 & 34,475 & 22,286 & 1567 & 153,661 & ${ }^{4}+12,768$ & $-18,603$ & .823 & 4.964 & 9.063 & 334 & $\left({ }^{6}\right)$ \\
\hline
\end{tabular}

${ }^{1}$ Equivalent to psi (pounds per square inch) used in common mining terminology.

${ }^{2}$ Determined graphically from figures $48-53$.

${ }^{3}$ Calculated from laboratory results used to compile figures $48-53$

${ }^{4}$ At highest recorded values before failure.

${ }^{5}$ Anomalously high reading, probably resulting from bad gage.

${ }^{6}$ See "Remarks" column with list of core sizes and densities for each numbered core.

compressive strength. This stress is also referred to by some authors as failure strength or ultimate strength.

\section{LABORATORY RESULTS}

Laboratory tests of unconfined and triaxial (confined) compressive strengths, unconfined tensile strengths, and creep properties of the coals were done by the USGS and by the USBM with cooperation of the
USGS. Triaxial and unconfined compressive tests were also done in the USGS laboratory by Y. Y. Youash $(1965 \mathrm{a}, \mathrm{b})$ on samples of roof rocks from the Sunnyside No. 1 Mine to assess the effect of laminations (resulting from penecontemporaneous slumping and burrowing by organisms) on the strengths of the rocks. Results of these various tests are given in tables 1-5. Unconfined tensile strengths are not included in the tables because the coal is very weak; all cores tested in tension failed between 27.58 and $51.71 \mathrm{kPa}\left(4\right.$ and $7.5 \mathrm{lbf} / \mathrm{in}^{2}$ ). 
TABLE 1.-Continued

MACHINED NX DRILL CORES

\begin{tabular}{|c|c|c|c|c|c|c|}
\hline \multirow{3}{*}{ Core No. } & \multirow{3}{*}{$\begin{array}{l}\text { Density* } \\
\left(\mathrm{g} / \mathrm{cm}^{3}\right)\end{array}$} & \multicolumn{4}{|c|}{$\begin{array}{c}\text { Core size after machining } \\
\text { to tolerances }\end{array}$} & \multirow{3}{*}{ Remarks } \\
\hline & & \multicolumn{2}{|c|}{$\begin{array}{l}\text { Measured } \\
\text { (inches) }\end{array}$} & \multicolumn{2}{|c|}{$\begin{array}{l}\text { Calculated } \\
\text { (centimeters) }\end{array}$} & \\
\hline & & Diameter & $\overline{\text { Length }}$ & Diameter & Length & \\
\hline $10 \mathrm{~N}$ & 1.27 & $27 / 64$ & $4^{23 / 64}$ & 5.40 & 11.07 & Ends of core epoxied to platens. \\
\hline lst cycle ................. & --. & -.- & -- & --. & -.- & \\
\hline $2 \mathrm{~d}$ cycle ................. & --- & $\cdots$ & $\cdots$ & --- & --- & Both tensional and flexural lateral failures in core. \\
\hline $13 N$ & 1.20 & --- & --- & $\cdots$ & --- & \\
\hline $15 \mathrm{~N}$ & 1.22 & $27 / 64$ & $2^{51 / 64}$ & 5.40 & 7.10 & Core cracked at $1,441-\mathrm{lbf} / \mathrm{in}^{2}\left(101.312-\mathrm{kg} / \mathrm{cm}^{2}\right)$ axial stress. \\
\hline lst cycle ................. & --- & $\cdots$ & --- & --- & --- & \\
\hline $2 \mathrm{~d}$ cycle ................. & --- & $-\cdots$ & --- & --- & --- & \\
\hline $16 \mathrm{~N}$ & 1.20 & $27 / 64$ & $2^{45 / 64}$ & 5.36 & 6.87 & \\
\hline lst cycle .................. & --- & --- & --- & --- & --- & \\
\hline $2 \mathrm{~d}$ cycle .................. & --- & --. & -.- & --- & -.- & \\
\hline $7 \mathrm{~N}$ & 1.35 & $27 / 64$ & $357 / 64$ & 5.36 & 9.88 & No loud pop at failure. \\
\hline $8 \mathrm{~N}$ & 1.37 & $26 / 16$ & $48 / 64$ & 5.32 & 10.48 & Several crunching sounds at failure. \\
\hline $11 \mathrm{~N}$ & 1.37 & $2 \frac{1}{1 / 8}$ & $4^{21 / 64}$ & 5.12 & 10.99 & $\begin{array}{l}\text { Taken to failure at constant load rate. Core cracked with } \\
\text { muffled pop sound at } 2,735-\mathrm{lbf} / \mathrm{in}^{2}\left(192.290-\mathrm{kg} / \mathrm{cm}^{2}\right) \text { axial } \\
\text { stress. Several crunching sounds when core failed. }\end{array}$ \\
\hline $14 \mathrm{~N}$ & 1.40 & $27 / 64$ & $46 / 64$ & 5.36 & 10.40 & Unusual strain before failure. Silent failure. \\
\hline $17 \mathrm{P}$ & 1.65 & $27 / 64$ & $3^{13 / 64}$ & 5.36 & 8.14 & Erratic strain during testing. No noise at failure. \\
\hline $5 \mathrm{~N}$ & --. & $27 / 64$ & $3^{28 / 64}$ & 5.36 & 8.73 & Cycled using constant loading rate. \\
\hline $\begin{array}{l}8 \text { th cycle ..................... } \\
4 \mathrm{~N} \text { (creep }\end{array}$ & --- & $\ldots$ & -- & -- & -- & Core failed with two loud bumping sounds. \\
\hline test) & $-\cdots$ & $27 / 64$ & $329 / 64$ & 5.36 & 8.77 & Loaded to two-thirds of axial stress at failure of core $12 \mathrm{~N}$. \\
\hline lst cycle ................. & --- & --- & --- & -- & --- & Waited 35 min for starting second loading. \\
\hline $2 \mathrm{~d}$ cycle ................ & $\ldots$ & --- & --- & --- & --- & Core idle $17.5 \mathrm{hrs}$ after second loading. \\
\hline 3d cycle .................. & -.- & --- & --.- & 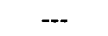 & $\ldots$ & Small crack about $1.5 \mathrm{~s}$ before failure. \\
\hline $12 \mathrm{~N}$ & $\cdots$ & $27 / 64$ & $3^{26 / 64}$ & 5.36 & 8.65 & $\begin{array}{l}\text { Very irregular lateral strain between } 39,000-\text { and } 81,000- \\
\mathrm{lbf} / \mathrm{in}^{2}\left(2.742 \times 10^{3} \text { - and } 5.695 \times 103-\mathrm{kg}^{2} \mathrm{~cm}^{2}\right) \text { load on platens. } \\
\text { Taken to failure at constant load rate. }\end{array}$ \\
\hline $20 \mathrm{~N}$ & 1.30 & $27 / 64$ & $4^{18 / 64}$ & 5.36 & 10.87 & $\begin{array}{l}\text { Irregular axial strain between } 8,000-\text { and } 12,300-\mathrm{lbf} / \mathrm{in}^{2} \\
\left(5.625 \times 10^{2} \text { - and } 8.648 \times 10^{2}-\mathrm{kg} / \mathrm{cm}^{2}\right) \text { load on platens. Taken } \\
\text { to failure at constant load rate. }\end{array}$ \\
\hline
\end{tabular}

*Analyst: T.C. Nichols, Jr.

\section{CONFINED AND UNCONFINED COMPRESSIVE TESTS}

Compressive tests done by the USGS on coal from the Sunnyside No. 1 Mine utilized a Forney concrete compression tester having a maximum capacity of $190,800 \mathrm{~kg}(200,000 \mathrm{lbs})$ of force. A Soiltest ${ }^{4}$ triaxial cell is placed in the compression tester for triaxial tests. This cell can be used with a maximum confining pressure of $562.5 \mathrm{~kg} / \mathrm{cm}^{2}$ or $5.516 \times 10^{4} \mathrm{kPa}(8,000$ $\left.\mathrm{lbf} / \mathrm{in}^{2}\right)$. Hydraulic fluid is pumped into the cell through

\footnotetext{
${ }^{4}$ The use of trade names (brand names) in this report is for descriptive purposes only and does not constitute endorsement by the U.S. Geological Survey.

${ }^{5}$ Standard NX drill core is $2 \frac{1}{8}$ in. diameter.
}

a port in the side; lead wires from electrical resistance strain gages mounted on the specimens come out through another port. All the tests were done on 54-mm- (21/8-in.-) diameter standardized NX drill cores $^{5}$. Attempts were made to standardize the length of cores at $108 \mathrm{~mm}\left(4 \frac{1}{4} \mathrm{in}\right.$.), but bedding planes in the cores commonly separated during specimen preparation so that most were shorter than $108 \mathrm{~mm}$. Ends of the cores were machined to parallelism within a tolerance of $0.0254 \mathrm{~mm}(0.001 \mathrm{in}$.) and the sides were smoothed. For specimens for the Sunnyside No. 1 Mine, actual dimensions of the cores as tested are given in table 1 . Before being placed in the cell the cores were enclosed in polyvinylchloride plastic sleeves. These sleeves overlapped machined steel platens at each end of the cores and were clamped to 
TABLE 2.-Unconfined compressive test results on 54-mm (21/8-in.) NX drill cores of coal from Sunnyside No. 3 Mine, Utah [Leaders (-.-) indicate no data. $\mathrm{lbf} / \mathrm{in}^{2}$ equivalent to psi (pounds per square inch) used in common mining terminology. Modified from F. L. Gaddy, E. R. Rodriguez, and T. C. Miller, U.S. Bureau of Mines, written commun., 1959]

\begin{tabular}{|c|c|c|c|c|c|c|c|c|c|c|c|c|c|c|c|}
\hline \multirow[b]{3}{*}{$\begin{array}{l}\text { Num- } \\
\text { ber } \\
\text { of } \\
\text { cores }\end{array}$} & \multicolumn{11}{|c|}{ Repeated loadings below failure stress } & \multirow{2}{*}{\multicolumn{4}{|c|}{ Compressive strength at failure }} \\
\hline & \multicolumn{3}{|c|}{$\begin{array}{l}\text { Maximum stress during } \\
\text { loading }\end{array}$} & \multicolumn{4}{|c|}{ Secant modulus of elasticity } & \multicolumn{2}{|c|}{$\begin{array}{l}\text { Poisson's } \\
\text { ratio }\end{array}$} & \multicolumn{2}{|c|}{$\begin{array}{l}\text { Permanent set on } \\
\text { repeated loading } \\
\text { (percent) }\end{array}$} & & & & \\
\hline & $\begin{array}{c}\mathrm{lbf} / \mathrm{in}^{2} \\
\text { (measured) }\end{array}$ & $\begin{array}{l}\mathrm{kg} / \mathrm{cm}^{2} \\
\text { (calcu- } \\
\text { lated) }\end{array}$ & $\begin{array}{l}\mathrm{kPa} \\
\text { (calcu- } \\
\text { lated) }\end{array}$ & $\begin{array}{l}\text { Mean, } \\
\mathrm{lbf} / \mathrm{in}^{2} \\
\times 10^{6}\end{array}$ & $\begin{array}{c}\text { Standard } \\
\text { deviation, } \\
\mathrm{lbf} / \mathrm{in}^{2} \\
\times 10^{6}\end{array}$ & $\begin{array}{l}\text { Mean, } \\
\mathrm{kg} / \mathrm{cm}^{2} \\
\times 10^{4}\end{array}$ & $\begin{array}{l}\text { Mean, } \\
\mathrm{kPa} \\
\times 10^{6}\end{array}$ & Mean & $\begin{array}{l}\text { Standard } \\
\text { deviation }\end{array}$ & Mean & $\begin{array}{l}\text { Standard } \\
\text { deviation }\end{array}$ & $\begin{array}{c}\text { Mean } \\
\text { measured, } \\
\mathrm{lbf} / \mathrm{in}^{2}\end{array}$ & $\begin{array}{l}\text { Standard } \\
\text { deviation, } \\
\mathrm{lb} / \mathrm{in}^{2}\end{array}$ & $\begin{array}{l}\text { Mean, } \\
\mathrm{kg} / \mathrm{cm}^{2}\end{array}$ & $\begin{array}{c}\text { Mean, } \\
\mathrm{kPa}\end{array}$ \\
\hline \multicolumn{16}{|c|}{ First loading } \\
\hline 3 & 150 & 10.6 & 1,034 & 0.309 & 0.122 & 2.173 & 2.131 & 0.106 & 0.032 & -- & -- & -.. & -- & -- & --- \\
\hline 3 & 300 & 21.1 & 2,069 & .345 & .105 & 2.426 & 2.379 & .147 & .032 & --. & -.. & --- & --. & ... & $\ldots$ \\
\hline 3 & 500 & 35.2 & 3,448 & .391 & .084 & 2.749 & 2.696 & .186 & .032 & $\ldots$ & ... & --- & -.. & -.- & --- \\
\hline 2 & 650 & 45.7 & 4,482 & .466 & .063 & 3.276 & 3.213 & .222 & .032 & ... & --- & $\ldots$ & --- & --- & $\ldots$ \\
\hline 2 & --- & $\cdots$ & $\cdots$ & $-\cdots$ & -- & --- & --- & -- & -- & 3.33 & 4.04 & -- & --- & -- & $\cdots$ \\
\hline \multicolumn{16}{|c|}{ Second loading ${ }^{1}$} \\
\hline 3 & 150 & 10.6 & 1,034 & 0.308 & 0.030 & 2.166 & 2.124 & 0.084 & 0.045 & $\ldots$ & $\cdots$ & -- & $\ldots$ & $-\cdots$ & -- \\
\hline 3 & 300 & 21.1 & 2,069 & .352 & .084 & 2.475 & 2.427 & .137 & .032 & $\cdots$ & -.- & --. & --. & --- & --- \\
\hline 3 & 500 & 35.2 & 3,448 & .406 & .077 & 2.855 & 2.799 & .183 & .032 & --. & --- & --- & --- & -.- & -.- \\
\hline 2 & 650 & 45.7 & 4,482 & .478 & .032 & 3.361 & 3.296 & .217 & .032 & --- & -.. & --- & -- & $\cdots$ & --- \\
\hline 2 & $\ldots$ & $\cdots$ & $\cdots$ & $\cdots$ & -- & --- & --- & --- & $\cdots$ & .84 & .99 &.-- & $\cdots$ & --- & -- \\
\hline 3 & --- & --- & -- & --- & --- & --. & --- & $\cdots$ & -- & -- & -- & 3,054 & 136 & 214.7 & 21,057 \\
\hline \multicolumn{16}{|c|}{ First loading ${ }^{2}$} \\
\hline 3 & 150 & 10.6 & 1,034 & 0.270 & 0.032 & 1.898 & 1.862 & 0.083 & 0.032 & --- & --- & --. & --- & --.- & ... \\
\hline 3 & 300 & 21.1 & 2,069 & .296 & .045 & 2.081 & 2.041 & .121 & .032 & $-\cdots$ & $\cdots$ & --- & $\cdots$ & $\cdots$ & $\cdots$ \\
\hline 3 & 500 & 35.2 & 3,447 & .347 & .055 & 2.440 & 2.393 & .159 & .032 & --- &.-- & --. & --- & --- & 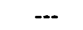 \\
\hline 1 & 650 & 45.7 & 4,482 & .436 & --- & 3.065 & 3.006 & .149 & $\cdots$ & $\cdots$ & --- & --- & $\ldots$ & --- & -.- \\
\hline 2 & -- & -- & --- & $\cdots$ & --- & --- & --- & --- & --. & 10.20 & 1.49 & --- & --- & --- & --- \\
\hline --- & --- & $\cdots$ & -- & $\cdots$ & $\cdots$ & --- & $\cdots$ & $--\cdot$ & $\cdots$ & 6.04 & --- & $\cdots$ & $\cdots$ & --. & $\cdots$ \\
\hline \multicolumn{16}{|c|}{ Second loading ${ }^{2}$} \\
\hline 3 & 150 & 10.6 & 1,034 & 0.262 & 0.045 & 1.842 & 1.807 & 0.089 & 0.045 & -.. & ... & --. & $\ldots$ & $\ldots$ & ... \\
\hline 3 & 300 & 21.1 & 2,069 & .321 & .045 & 2.257 & 2.213 & .132 & .045 & --- & --- & --- & --. & --- & --- \\
\hline 3 & 500 & 35.2 & 3,448 & .376 & .045 & 2.644 & 2.593 & .172 & .045 & $\cdots$ & --. & --- & -.. & --. & $\ldots$ \\
\hline 1 & 650 & 45.7 & 4,482 & .464 & $\cdots$ & 3.199 & 3.199 & .182 & -- & $\cdots$ & -- & --- & -- & -- & $\cdots$ \\
\hline 2 & -- & $\cdots$ & $\cdots$ & $\cdots$ & $\cdots$ & --- & $\cdots$ & $\cdots$ & --- & 1.05 & .50 & --- & --. & --- & --- \\
\hline$\cdots$ & $\cdots$ & -- & -- & $\cdots$ & --- & --- & --- & --- & --- & .71 & -- & -- & $\cdots$ & --- & $\cdots$ \\
\hline 3 & --- & $\cdots$ & --- & $\cdots$ & --- & $\cdots$ & $-\cdots$ & -- & $\cdots$ & $-\cdots$ & --- & 3,630 & 242 & 255.2 & 25,029 \\
\hline
\end{tabular}

'As-received (natural) moisture content. ${ }^{2}$ Saturated 75 percent.

TABLE 3.-Unconfined compressive tests on coal cubes from Sunnyside No. 3 Mine, Utah

[Leaders (---) indicate no data. lbf/in² equivalent to psi (pounds per square inch) used in common mining terminology. Modified from F. L. Gaddy, E. R. Rodriguez, and T. C. Miller, U.S. Bureau of Mines, written commun., 1959]

\begin{tabular}{|c|c|c|c|c|c|c|c|c|c|c|c|c|c|c|c|c|c|}
\hline \multirow[b]{3}{*}{$\begin{array}{c}\text { Num- } \\
\text { ber } \\
\text { of } \\
\text { cubes }\end{array}$} & \multicolumn{11}{|c|}{ Repeated loadings below failure stress of $76-\mathrm{mm}$ (3-in.) cubes } & \multicolumn{6}{|c|}{ Load at failure under compression } \\
\hline & \multicolumn{3}{|c|}{$\begin{array}{l}\text { Maximum stress during } \\
\text { loading }\end{array}$} & \multicolumn{4}{|c|}{ Secant modulus of elasticity } & \multicolumn{2}{|c|}{ Poisson's ratio } & \multicolumn{2}{|c|}{$\begin{array}{l}\text { Permanent set on } \\
\text { repeated loadings } \\
\text { (percent) }\end{array}$} & \multicolumn{3}{|c|}{ 76-mm (3-in.) cubes } & \multicolumn{3}{|c|}{ 48-mm (17/8-in.) cubes } \\
\hline & $\begin{array}{c}\mathrm{lbf} / \mathrm{in}^{2} \\
\text { (measured) }\end{array}$ & $\begin{array}{l}\mathrm{kg} / \mathrm{cm}^{2} \\
\text { (calcu- } \\
\text { lated) }\end{array}$ & $\begin{array}{l}\mathrm{kPa} \\
\text { (calcu- } \\
\text { lated) }\end{array}$ & $\begin{array}{l}\text { Mean, } \\
\mathrm{lbf} / \mathrm{in}^{2} \\
\times 10^{6}\end{array}$ & $\begin{array}{c}\text { Standard } \\
\text { deviation, } \\
\text { lbf/in } \\
\times 10^{6}\end{array}$ & $\begin{array}{l}\text { Mean, } \\
\mathrm{kg} / \mathrm{cm}^{2} \\
\times 10^{6}\end{array}$ & $\begin{array}{l}\text { Mean, } \\
\mathrm{kPa} \\
\times 10^{6}\end{array}$ & Mean & $\begin{array}{l}\text { Standard } \\
\text { deviation }\end{array}$ & Mean & $\begin{array}{l}\text { Standard } \\
\text { deviation }\end{array}$ & $\begin{array}{l}\text { Mean } \\
\text { measured, } \\
\mathrm{lbf} / \mathrm{in}^{2}\end{array}$ & $\begin{array}{l}\text { Mean } \\
\text { calcu- } \\
\text { lated, } \\
\mathrm{kg} / \mathrm{cm}^{2}\end{array}$ & $\begin{array}{c}\text { Mean } \\
\text { calcu- } \\
\text { lated, } \\
\mathrm{kPa}\end{array}$ & $\begin{array}{c}\text { Mean } \\
\text { measured } \\
\mathrm{lbf} / \mathrm{in}^{2}\end{array}$ & $\begin{array}{l}\text { Mean } \\
\text { calcu- } \\
\text { lated, } \\
\mathrm{kg} / \mathrm{cm}^{2}\end{array}$ & $\begin{array}{c}\text { Mean } \\
\text { calcu- } \\
\text { lated, } \\
\mathrm{kPa}\end{array}$ \\
\hline \multicolumn{18}{|c|}{ First loading ${ }^{1}$} \\
\hline 3 & 300 & 21.1 & 2,069 & 0.334 & 0.059 & 2.348 & 2.303 & 0.101 & 0.022 & -.. & -.- & $\ldots$ & ... & -.- & -.- & -.. & ... \\
\hline 3 & 500 & 35.2 & 3,448 & .377 & .063 & 2.651 & 2.599 & .146 & .022 & ... & ... & -.- & $\ldots$ & ... & ... & -.- & -.. \\
\hline 3 & 800 & 56.3 & 5,516 & .401 & .032 & 2.819 & 2.765 & .178 & .000 & 7.97 & 4.10 & $\cdots$ & --- & $\cdots$ & $\ldots$ & $\cdots$ & -.. \\
\hline \multicolumn{18}{|c|}{ Second loading ${ }^{1}$} \\
\hline 3 & 300 & 21.1 & 2,069 & 0.390 & 0.039 & 2.742 & 2.689 & 0.146 & 0.022 & --- & -.- & --- & --- & --- & $\ldots$ & ... & -- \\
\hline 3 & 500 & 35.2 & 3,448 & .421 & .039 & 2.960 & 2.901 & .104 & .000 & $\ldots$ & --. & -.- & ... & -.- & -.- & -.. & -.. \\
\hline 3 & 800 & 56.3 & 5,516 & .456 & .045 & 3.206 & 3.144 & .219 & .022 & .082 & .70 & -.- & $\ldots$ & -.- & --- & --. & $\ldots$ \\
\hline \multicolumn{18}{|c|}{ Compressive strength at failure } \\
\hline${ }^{1} 17$ & $\bar{\cdots}$ & $\ldots$ & $\cdots$ & $\cdots$ & $\ldots$ & $\ldots$ & $\ldots$ & $\ldots$ & $\cdots$ & $\ldots$ & $\bar{\cdots}$ & 4,574 & 321.6 & 31,538 & $\bar{n}$ & $\cdots$ & $\ldots$ \\
\hline${ }^{2} 4$ & -.- & -.. & $\cdots$ & -.- & ... & -.- & -.- & --- & --- & ... & --- & 4,504 & 316.7 & 31,055 & -.- & -.- & $\cdots$ \\
\hline${ }^{1} 19$ & --- & -.- & ... & $\ldots$ & --- & -.. & -.. & --. & -.. & ... & -.- & -.. & ..- & --. & 5,749 & 404.2 & 39,639 \\
\hline${ }^{2} 5$ & -.- & --- & $\cdots$ & $\ldots$ & -.. & -.. & -.- & ... & -.- & - & ..- & -.. & ... & $\ldots$ & 3,822 & 268.7 & 26,353 \\
\hline
\end{tabular}

${ }^{1}$ As-received (natural) moisture content.

${ }^{2}$ Saturated 75 percent. 
the platens. A few cores were fastened to the platens with epoxy before testing to study the behavior of coal that adhered to roof rocks (table 1).

Before testing by the USGS, all cores were allowed to dry in the laboratory for several weeks to permit moisture acquired during sawing, coring, and machining to evaporate. Previous tests made in cooperation with the USBM on specimens from the Sunnyside No. 3 Mine (tables 2, 3), however, indicated that moisture content did not affect the strength of the Sunnyside coal in a statistically significant manner (F. L. Gaddy, E. R. Rodriguez, and T. C. Miller, U.S. Bureau of Mines, written commun., 1959).

For triaxial compressive tests, after the cores had dried, SR-4 type electrical resistance strain gages were attached with acetate cement to the cores. Gages were placed in both longitudinal and transverse positions to measure longitudinal and lateral strain. Standard rate of axial (longitudinal) loading was $6.895 \times 10^{4} \mathrm{kPa}$ $\left(10,000 \mathrm{lbf} / \mathrm{in}^{2}\right)$ per minute, but loading was interrupted at intervals during both the unconfined and confined tests to read strain. Rates of loading were changed during some tests of coal to study the effect of varied loading rates on failure stress. Some cores also were subjected to two or more cycles of loading and unloading to determine the effects of hysteresis on ultimate compressive strengths (table 1). All tests were carried to failure.

Compressive tests of coal from the Sunnyside No. 3 Mine, done by the USBM in cooperation with the U.S. Bureau of Reclamation (USBR) and the USGS (F. L. Gaddy, E. R. Rodriguez, and T. C. Miller, U.S. Bureau of Mines, written commun., 1959), followed the standard procedures used for concrete testing by the U.S. Bureau of Reclamation $(1949,1953)$. Most of the tests were done on cores cut to $54-\mathrm{mm}\left(2 \frac{1}{8} 8\right.$-in.) diameter by 108-mm (41/4-in.) length (listed in table 2). The ultimate strengths of cores can be compared to cubes of coal, $76.2-\mathrm{mm}$ and $47.6-\mathrm{mm}$ cubes (3- and 17/8-in.), which were also tested in unconfined compression (table 3). In general, the results obtained by the USBM (table 4) on coal cubes were within the range of compressive strengths determined by the USGS on unconfined coal cores (table 1). Specimens used for the USBM tests were prepared similarly to those used for the USGS tests, except that smooth bearing caps consisting of a mixture of fireclay and sulfur were applied to both ends of the cores and of the cubes. After the caps were applied, exact dimensions of the specimens were measured. The cores were placed in rubber jackets to protect them from hydraulic fluid used in triaxial testing. Loading rates for both confined and unconfined tests were $13,790 \mathrm{kPa}\left(2,000 \mathrm{lbf} / \mathrm{in}^{2}\right)$ per minute. A measuring frame was used to measure strain of unconfined cores; SR-4 type electrical resist-
TABLE 4.-Summary of triaxial compressive test results, on NX drill cores from a block of coal, Sunnyside No. 3 Mine, Utah

[Leaders (---) indicate no data available. lbf/in2 equivalent to psi (pounds per square inch) used in common mining terminology. Modified from F. L. Gaddy, E. R. Rodriguez, and T. C. Miller, U.S. Bureau of Mines, written commun., 1959]

\begin{tabular}{|c|c|c|c|c|c|}
\hline \multicolumn{3}{|c|}{ Lateral stress } & \multicolumn{3}{|c|}{$\begin{array}{c}\text { Compressive strength } \\
\text { (averages of three samples) }\end{array}$} \\
\hline $\begin{array}{c}\mathrm{lbf} / \mathrm{in}^{2} \\
\text { (measured) }\end{array}$ & $\begin{array}{c}\mathrm{kg} / \mathrm{cm}^{2} \\
\text { (calculated) }\end{array}$ & $\begin{array}{c}\mathrm{kPa} \\
\text { (calculated) }\end{array}$ & $\begin{array}{c}\mathrm{lbf} / \mathrm{in}^{2} \\
\text { (calculated) }\end{array}$ & $\begin{array}{c}\mathrm{kg} / \mathrm{cm}^{2} \\
\text { (calculated) }\end{array}$ & $\begin{array}{c}\mathrm{kPa} \\
\text { (calculated) }\end{array}$ \\
\hline 0 & --- & -- & 2,299 & 161.6 & 15,850 \\
\hline 200 & 14.1 & 1,380 & 5,683 & 399.6 & 39,180 \\
\hline 600 & 42.2 & 4,140 & 7,937 & 558.0 & 54,730 \\
\hline 1,000 & 70.3 & 6,900 & 9,245 & 650.0 & 63,740 \\
\hline 1,600 & 112.5 & 11,030 & 11,483 & 807.3 & 79,180 \\
\hline 2,200 & 154.7 & 15,170 & 12,279 & 863.3 & 84,660 \\
\hline${ }^{1} 2,500$ & 175.8 & 17,240 & 13,642 & 959.7 & 94,060 \\
\hline 2,800 & 196.9 & 19,310 & 13,366 & 939.7 & 92,160 \\
\hline 4,000 & 281.2 & 27,580 & 16,620 & $1,168.5$ & 114,600 \\
\hline 5,200 & 365.6 & 35,850 & 18,581 & $1,306.3$ & 128,120 \\
\hline 6,800 & 478.1 & 46,890 & 21,525 & $1,513.4$ & 148,420 \\
\hline 8,500 & 597.6 & 58,608 & 24,038 & $1,690.0$ & 165,740 \\
\hline
\end{tabular}

${ }^{1}$ Two samples only.

ance strain gages were used to measure strain during triaxial shear (confined compression) tests. The USBM triaxial shear results are summarized in table 4.

Results of unconfined and triaxial testing by the USGS (table 1) of coal cores from the Sunnyside No. 1 Mine are summarized in a series of stress-strain curves (figs. 48-52). These curves illustrate several aspects of the behavior of Sunnyside coal in response to various stress conditions. All but one of the cores were cut with the long axis of the cylinder normal to the bedding in the coal. Figure 48 illustrates three coal cores loaded parallel to their long axes with no confining stress. In order to study possible hysteresis of the samples, all of these cores were subjected to two cycles of loading, the first cycle to values well below the anticipated failure strength and the second cycle to ultimate failure. As shown in table 1, the compressive strengths (stress at failure) varied by more than a factor of six. In addition, the amount of hysteresis (Thrush, 1968, p. 566) or permanent strain (also referred to as permanent set; that is, the comparison of all first-cycle data (table 1)) remaining in the cores after release of the first loading cycle varies as much as five times. The ranges of hysteresis in the samples tested by the USBM (tables 2,3 ) from the Sunnyside No. 3 Mine are similar to the ranges of the samples tested by the USGS from the Sunnyside No. 1 Mine. Poisson's ratios for the Sunnyside No. 1 Mine samples appear to be greater than the ratios for the Sunnyside No. 3 Mine samples, although this apparent difference may have resulted from different testing procedures. These variations, however, appear to be less when No. 1 Mine coal also is 
stressed laterally. The tangent and secant moduli for axially stressed individual Sunnyside No. 1 cores vary as much as six times (table 1)

Results of triaxial compressive testing of cores from the Sunnyside No. 1 Mine at $1,379 \mathrm{kPa}\left(200 \mathrm{lbf} / \mathrm{in}^{2}\right)$ lateral stress (confining pressure) showed that the compressive strengths of the samples in the triaxial tests were as much as 10 times greater than in the unconfined tests (table 1; figs. 48, 49). The average compressive strength of the Sunnyside No. 1 Mine samples was $51,706 \mathrm{kPa}\left(7,499 \mathrm{lbf} / \mathrm{in}^{2}\right.$; table 1$)$, but the strength of the Sunnyside No. 3 Mine samples was $39,184 \mathrm{kPa}\left(5,683 \mathrm{lbf} / \mathrm{in}^{2}\right.$; table 4). Tests of one core cut parallel to bedding showed no significant differences from those cut normal to bedding; similar results were obtained during tests of British coals by Hobbs (1964, p. 219). At $6,895 \mathrm{kPa}\left(1,000 \mathrm{lbf} / \mathrm{in}^{2}\right)$ lateral stress, the average compressive strength of Sunnyside No. 1 Mine coal was $76,831 \mathrm{kPa}\left(11,143 \mathrm{lbf} / \mathrm{in}^{2}\right.$; table 1) as compared with $63,740 \mathrm{kPa}\left(9,245 \mathrm{lbf} / \mathrm{in}^{2}\right)$ for Sunnyside No. 3 Mine coal (table 4). Slopes of the stress-strain curves for Sunnyside No. 1 Mine samples tested using $1,379 \mathrm{kPa}\left(200 \mathrm{lbf} / \mathrm{in}^{2}\right)$ lateral stress (fig. 49) suggest less variation in compressive strength with increasing lateral stress, as is also shown by the curves for samples tested to $6,895 \mathrm{kPa}\left(1,000 \mathrm{lbf} / \mathrm{in}^{2}\right.$; fig. 50). Only one sample was tested at $34,475 \mathrm{kPa}\left(5,000 \mathrm{lbf} / \mathrm{in}^{2}\right)$ lateral stress (fig. 51); results of this test indicated that the compressive strength is about twice the strength of samples tested at $6,895 \mathrm{kPa}\left(1,000 \mathrm{lbf} / \mathrm{in}^{2}\right)$. Figures 49-51 also show a number of irregularities in the stress-strain relationships in which strain decreased as stress was increased. These irregularities may result either from molecular rearrangements of chemical constituents in the coal or from storing of energy along cracks and defects, as suggested by Ingles and others (1973) for similar irregularities in sandstones. Results from triaxial compressive tests of cores from the Sunnyside No. 3 Mine (F. L. Gaddy, E. R. Rodriguez, and T. C. Miller, written commun., 1959) did not indicate any such irregularities. The results of testing one core cut parallel to the bedding in coal (core $17 \mathrm{P}$, table 1 and fig. 49) show no significant difference in failure strength or modulus from cores cut normal to bedding and tested at the same confining stress. Such anisotropy of coal strength, however, was reported by Jeremic (1981, p. 69, 71) for coal from Lethbridge, Alberta, Canada. Although the Lethbridge coal is equivalent to Sunnyside coal in geologic age, it has been subjected to a much different geologic history involving overthrust faulting, so that its stress history is much different.
Figure 52 shows a series of curves illustrating the effects of lateral stress and cycling of axial stress on the strength of Sunnyside No. 1 Mine coal. These curves show the triaxial compressive test results with the axial deformation of the cores plotted against differential stress (longitudinal, or axial, loading minus lateral stress). Tangent lines are drawn to these curves, and the tangent modulus of elasticity (Young's modulus) was measured from the tangent lines. Tangent moduli vary considerably (table 1 ), but no apparent pattern resulted from testing at different lateral stress values (fig. 52), except that the moduli increased with higher lateral stresses. Tests on British coals, however, indicated that Young's modulus became nearly constant during tests at confining stresses above 6,895 $\mathrm{kPa}\left(1,000 \mathrm{lbf} / \mathrm{in}^{2}\right)$ (Hobbs, 1964, p. 220). These values cannot be compared directly to the results from Sunnyside No. 3 Mine coal because of different laboratory and measuring procedures, but the measured values of the secant modulus of elasticity for unconfined cores of Sunnyside No. 1 Mine coal (table 1) show much greater ranges of values than do results from unconfined samples of Sunnyside No. 3 Mine coal (table 2).

All cores tested under repeated loading cycles showed varying amounts of hysteresis or permanent set. Although most of the hysteresis followed the first stress cycle (table 1), some was observed after the seven cycles to which one sample was subjected during triaxial compressive testing. The hysteresis may be reduced with time; the permanent set may not really be permanent because the coal slowly recovers. During the test represented by figure 53 , however, some hysteresis remained even after the core was at rest for several hours. This core was loaded twice to two-thirds of the axial stress at which other cores failed that were loaded at constant rates under $6,895-\mathrm{kPa}(1,000-$ $\mathrm{lbf} / \mathrm{in}^{2}$ ) lateral stress; the third cycle was carried to failure. The core showed a slight decrease in modulus during the third cycle as compared to other cores tested at the same confining stress (table 1 ).

FIGURE 48 (facing page).-Stress-strain curves for unconfined compressive strength test of coal cores from Sunnyside No. 1 Mine, Utah. $A$, Core $10 \mathrm{~N}$ subjected to two stress cycles, ends fastened to steel platens of testing machine with epoxy; $B$, Core $15 \mathrm{~N}$ subjected to two stress cycles, ends of core free to slip on platens; $C$, Core $16 \mathrm{~N}$ subjected to two stress cycles, ends of core free to slip on platens. Arrows indicate directions of increasing and decreasing axial stress. Number of arrows on each line segment corresponds to number of stress cycle for core listed in table 1. Dots are recorded datum points. Dashed line and queries(??) are projected values due to gauge failure. 


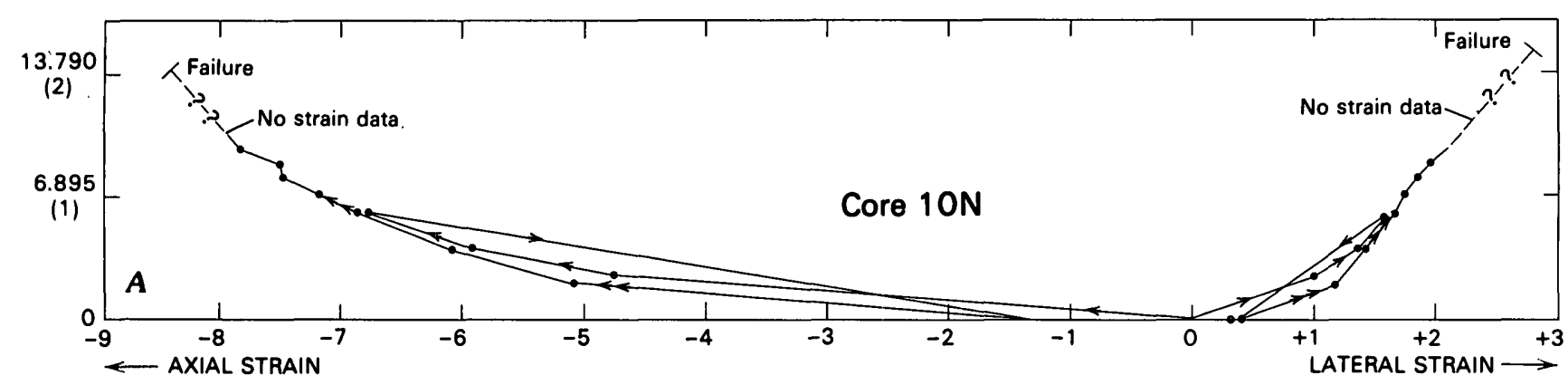
41.370
(6)
Axial and lateral
strains in $10^{3}$ micrometers/meter
$\left(10^{3}\right.$ microinches/inch)

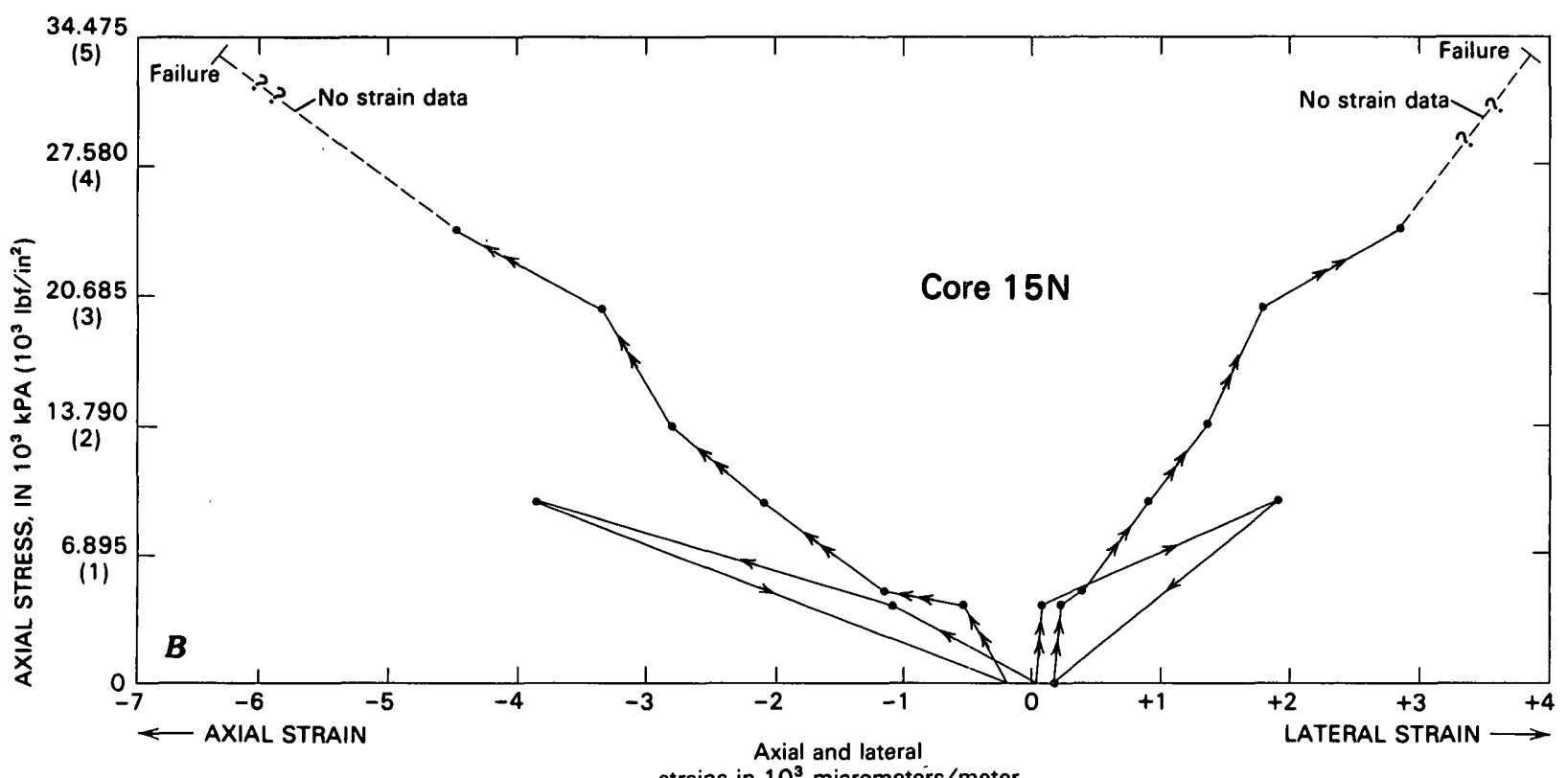

27.580 strains in $10^{3}$ micrometers $/ \mathrm{meter}$

(4)

$\left(10^{3}\right.$ microinches/inch)

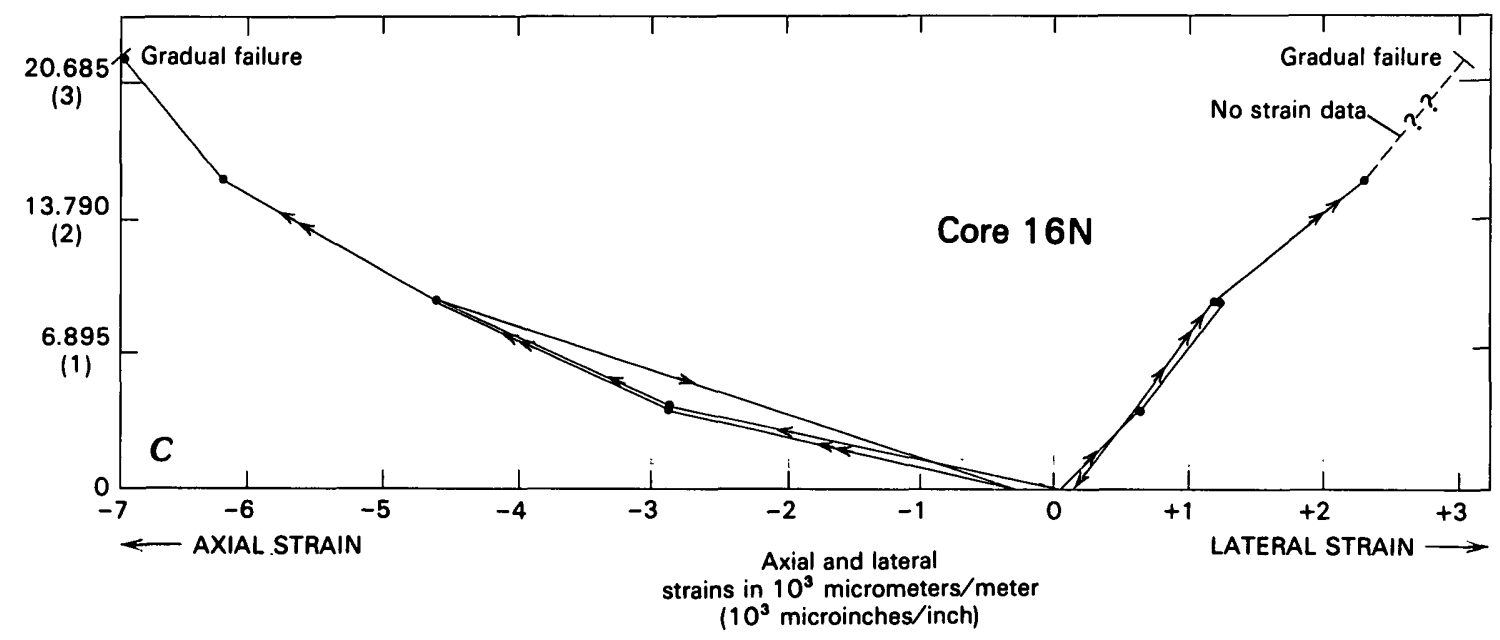


Additional unconfined and triaxial compressive testing of material from the Sunnyside coal bed was done by Crouch and Fairhurst (1973, p. 44-45), using samples from the Sunnyside Mines as well as from the Geneva Mine in the southern part of the district. These tests were done to study any possible differences between coal from Sunnyside that was not believed to be prone to bump and from the Geneva Mine that was known to be bump-prone (Crouch and Fairhurst, 1973, p. 28, 44). No differences were found. The results of Crouch and Fairhurst (1973, p. 43) indicated that the coal from the Sunnyside bed was two to three times stronger in unconfined compression than were our samples represented in table 1 . In contrast, the triaxial compressive results shown in tables 1 and 4 indicated that the coal was about 20 percent stronger under $6,895-\mathrm{kPa}\left(1,000-\mathrm{lbf} / \mathrm{in}^{2}\right)$ and $34,480-\mathrm{kPa}\left(5,000-\mathrm{lbf} / \mathrm{in}^{2}\right)$ confining stress than did the results of Crouch and Fairhurst (1973, p. 45), probably because of differing laboratory procedures.

Additional triaxial compressive strengths of coals from the Sunnyside No. 1 and No. 2 Mines were given by Scheibner (1979, p. $71,73,88$; table 5 ). This coal was obtained from areas in both mines that were unmined at the times of our investigations. Scheibner's results on unconfined cores indicated that the Sunnyside No. 1 Mine coal was about twice as strong as did our tests (table 1). Scheibner's results also indicated that unconfined cores of coal with "high sonic velocity" from the Sunnyside No. 2 Mine were two to three times as strong as those we tested from No. 1 Mine. Coal cores with "low sonic velocity" from the Sunnyside No. 2 Mine, however, were equivalent in strength to our cores from No. 1 Mine (tables 1, 5). At confining stresses of $6,895 \mathrm{kPa}\left(1,000 \mathrm{lbf} / \mathrm{in}^{2}\right)$ for coal from No. 1 Mine, and 5,516 kPa $\left(800 \mathrm{lbf} / \mathrm{in}^{2}\right)$ for coal from No. 2 Mine, Scheibner's results (table 5) are equivalent to our results from No. 1 Mine (table 1). The arithmetic mean of Poisson's ratio for both No. 1 and No. 2 Mines (Scheibner, 1979, p. 63, 67, 88) is equivalent to our results from No. 1 Mine (table 1). The mean of the secant modulus of elasticity, as indicated by Scheibner for coal in No. 1 and No. 2 Mines, ranged from $2.27 \times 10^{6}$ to $3.65 \times 10^{6} \mathrm{kPa}\left(0.33 \times 10^{6}\right.$ to $\left.0.53 \times 10^{6} \mathrm{lbf} / \mathrm{in}^{2}\right)$, which was within the ranges of our results (table 1 ).

Results of the triaxial testing of coal cores from both the Sunnyside No. 1 and No. 3 Mines are shown in figure 54 . The two graphs were constructed by drawing semicircles (Mohr's circles) that intersect the horizontal axis at two points representing the confining stress and axial stress at failure. The radii of the circles
TABLE 5.-Results of triaxial compressive tests on cores from three blocks of coal, Sunnyside No. 1 and No. 2 Mines, Utah

[Data from Scheibner, 1979 , p. 71, 73, 88]

\begin{tabular}{|c|c|c|c|}
\hline \multicolumn{2}{|c|}{ Confining stress } & \multicolumn{2}{|c|}{ Axial stress } \\
\hline $\begin{array}{c}\mathrm{lbf} / \mathrm{in}^{2} \\
\text { (measured) }\end{array}$ & $\begin{array}{c}\mathrm{kPa} \\
\text { (calculated) }\end{array}$ & $\begin{array}{c}\mathrm{lbf} / \mathrm{in}^{2} \\
\text { (measured) }\end{array}$ & $\begin{array}{c}\mathrm{kPa} \\
\text { (calculated) }\end{array}$ \\
\hline \multicolumn{4}{|c|}{ No. 1 Mine-13th Left and 16th Left } \\
\hline 0 & 0 & 6,000 & 41,370 \\
\hline 0 & 0 & 4,900 & 33,790 \\
\hline 500 & 3,450 & 9,050 & 63,400 \\
\hline 500 & 3,450 & 7,550 & 52,060 \\
\hline 500 & 3,450 & 9,180 & 63,090 \\
\hline 1,000 & 6,900 & 13,050 & 89,980 \\
\hline 1,000 & 6,900 & 13,250 & 91,360 \\
\hline 1,000 & 6,900 & 13,400 & 92,390 \\
\hline \multicolumn{4}{|c|}{ No. 1 Mine-17th Left } \\
\hline 1,000 & 6,900 & 8,390 & 57,830 \\
\hline 2,000 & 13,790 & 11,760 & 81,070 \\
\hline 3,000 & 20,690 & 15,560 & 107,280 \\
\hline
\end{tabular}

\begin{tabular}{|c|c|c|c|}
\hline \multicolumn{4}{|c|}{$\begin{array}{l}\text { No. } 2 \text { Mine-Coal with "high sonic velocity," } \\
\text { approximately } 2,112 \mathrm{~m} / \mathrm{s}(6,930 \mathrm{ft} / \mathrm{s})\end{array}$} \\
\hline 0 & 0 & 1,360 & 9,380 \\
\hline 0 & 0 & 2,950 & 18,270 \\
\hline 0 & 0 & 2,900 & 19,960 \\
\hline 0 & 0 & 2,980 & 20,550 \\
\hline 400 & 2,790 & 7,850 & 54,130 \\
\hline 400 & 2,790 & 6,400 & 44,130 \\
\hline 400 & 2,790 & 7,780 & 53,640 \\
\hline 800 & 5,520 & 8,060 & 55,570 \\
\hline 800 & 5,520 & 7,220 & 49,780 \\
\hline 800 & 5,520 & 7,220 & 54,470 \\
\hline 800 & 5,520 & 8,280 & 57,090 \\
\hline \multicolumn{4}{|c|}{$\begin{array}{l}\text { No. } 2 \text { Mine-Coal with "low sonic velocity," } \\
\text { approximately } 1,949 \mathrm{~m} / \mathrm{s}(3,440 \mathrm{ft} / \mathrm{s})\end{array}$} \\
\hline 0 & 0 & 3,920 & 27,030 \\
\hline 0 & 0 & 5,600 & 38,610 \\
\hline 0 & 0 & 4,020 & 27,720 \\
\hline 0 & 0 & 5,140 & 35,440 \\
\hline 400 & 2,790 & 8,360 & 57,640 \\
\hline 400 & 2,790 & 9,940 & 68,540 \\
\hline 400 & 2,790 & 9,450 & 65,160 \\
\hline 400 & 2,790 & 9,300 & 64,120 \\
\hline 800 & 5,520 & 10,900 & 74,160 \\
\hline 800 & 5,520 & 11,600 & 79,980 \\
\hline 800 & 5,520 & 10,000 & 68,950 \\
\hline 800 & 5,520 & 10,950 & 75,500 \\
\hline
\end{tabular}

thus are equal to

$$
\frac{\text { axial stress - confining stress }}{2}
$$

Curves were fitted mechanically to be tangent to each series of circles. These curves represent the ultimate failure strength of the Sunnyside coal bed in the two mines. These results, however, indicate that the strength of Sunnyside coal does not increase linearly 
with increasing confining (lateral) stress as did the strength of Canadian coals tested by Jeremic (1981, p. 71).

The slopes of the tangent curves in figure 54 decreased as the confining stress increased; the shear stress at failure thus increases with increasing confining stress. If the coal were tested at high-enough confining stresses, these curves should asymptotically approach the horizontal. The confining stresses used in the testing programs, however, probably were high enough to permit some generalizations concerning the behavior of the Sunnyside coal bed at depths and stresses apt to be encountered in underground mining. The coal tested from the Sunnyside No. 3 Mine (fig. 54B) was stronger under high confining stress than was coal from the Sunnyside No. 1 (fig. 54A). Although the coal bed was not sampled statistically either vertically or horizontally in either mine (all cores were cut from two large selected samples), the stronger coal in the Sunnyside No. 1 Mine may account for the more violent failures of roofs and ribs in No. 1 Mine as compared to No. 3 Mine. Although no data are available, our subjective observations also indicate that actual coal bumps were more violent in No. 1 Mine, perhaps because of the stronger coal. Violent bumps, however, did occur in No. 3 Mine. The causes of these apparent differences in the violence of bumps probably result in part from different mining techniques as well as from different geologic characteristics. Triaxial compressive tests of several British coals indicated that although the yield strengths of different coals tested in unconfined compression varied by as much as 14 to $l$, the strengths varied by only 2 to 1 at $34,490-\mathrm{kPa}\left(5,000-\mathrm{lbf} / \mathrm{in}^{2}\right)$ confining stress (Hobbs, 1964, p. 216-219).

Using samples from the Sunnyside No. 1 Mine, Youash $(1965 \mathrm{a}, \mathrm{b})$ tested the strength of roof rocks containing large horizontal burrows in unconfined and triaxial compressive tests. The results of these tests (table 6) indicate that the orientation of layering in the rocks with respect to the directions of principal stresses influences the failure strength. The results also provide a comparison of roof strength with coal strength. Failure strength of roof rock (axial stressconfining stress) is lowest when the layering is at an angle of about $30^{\circ}-45^{\circ}$ to the axial (maximum principal) stress (Youash, 1965a, p. 69, 71-72). Although when unconfined, the rock is strongest when the layering is normal to the axial stress, triaxial tests indicate that when confined to $31,028 \mathrm{kPa}(4,500$ $\mathrm{lb} / \mathrm{in}^{2}$ ) the rock is strongest when the layering is parallel to the axial stress. This increased strength probably occurs because the friction across layering planes increases, preventing failure, and causes mine
TABLE 6. - Results of triaxial compressive tests of roof rock, Sunnyside No. 1 Mine, Utah

[lbf/in ${ }^{2}$ equivalent to psi (pounds per square inch) used in common mining terminology. Analysts: Y.Y. Youash, George Erickson, R.A. Speirer, and J.C. Thomas. Modified from Youash, 1965a, p. 73]

\begin{tabular}{|c|c|c|c|c|c|c|}
\hline \multicolumn{3}{|c|}{ Confining (lateral) stress } & \multicolumn{3}{|c|}{$\begin{array}{l}\text { Axial (longitudinal) } \\
\text { stress at failure }\end{array}$} & \multirow{2}{*}{$\begin{array}{l}\text { Angle between } \\
\text { layering and } \\
\text { direction of } \\
\text { mininum } \\
\text { principal stress } \\
\text { (degrees) }\end{array}$} \\
\hline $\begin{array}{c}\mathrm{lbf} / \mathrm{in}^{2} \\
\text { (measured) }\end{array}$ & $\begin{array}{l}\mathrm{kg} / \mathrm{cm}^{2} \\
\text { calcul- } \\
\text { lated) }\end{array}$ & $\begin{array}{c}\mathrm{kPa} \\
\text { (calcu- } \\
\text { lated) }\end{array}$ & $\begin{array}{c}\mathrm{lbf} / \mathrm{in}^{2} \\
\text { (measured) }\end{array}$ & $\begin{array}{l}\mathrm{kg} / \mathrm{cm}^{2} \\
\text { (calcu- } \\
\text { lated) }\end{array}$ & $\begin{array}{c}\mathrm{kPa} \\
\text { (calcu- } \\
\text { lated) }\end{array}$ & \\
\hline 0 & 0 & 0 & 14,500 & 1,020 & 99,980 & 0 \\
\hline 0 & 0 & 0 & 12,000 & 844 & 82,740 & 15 \\
\hline 0 & 0 & 0 & 10,000 & 703 & 68,950 & 30 \\
\hline 0 & 0 & 0 & 9,000 & 633 & 62,055 & 45 \\
\hline 0 & 0 & 0 & 7,500 & 527 & 51,713 & 60 \\
\hline 0 & 0 & 0 & 10,500 & 738 & 72,398 & 75 \\
\hline 0 & 0 & 0 & 13,000 & 914 & 89,635 & 90 \\
\hline 1,500 & 106 & 10,343 & 23,500 & 1,652 & 162,033 & 0 \\
\hline 1,500 & 106 & 10,343 & 24,500 & 1,723 & 168,928 & 15 \\
\hline 1,500 & 106 & 10,343 & 18,500 & 1,301 & 127,558 & 30 \\
\hline 1,500 & 106 & 10,343 & 17,500 & 1,230 & 120,663 & 45 \\
\hline 1,500 & 106 & 10,343 & 19,500 & 1,371 & 134,453 & 60 \\
\hline 1,500 & 106 & 10,343 & 19,000 & 1,336 & 131,005 & 75 \\
\hline 1,500 & 106 & 10,343 & 24,000 & 1,687 & 165,480 & 90 \\
\hline 3,000 & 211 & 20,685 & 32,000 & 2,250 & 220,640 & 0 \\
\hline 3,000 & 211 & 20,685 & 29,500 & 2,074 & 203,403 & 15 \\
\hline 3,000 & 211 & 20,685 & 27,000 & $1 ; 898$ & 186,165 & 30 \\
\hline 3,000 & 211 & 20,685 & 24,500 & 1,723 & 168,928 & 45 \\
\hline 3,000 & 211 & 20,685 & 27,500 & 1,933 & 189,613 & 60 \\
\hline 3,000 & 211 & 20,685 & 26,500 & 1,863 & 182,718 & 75 \\
\hline 3,000 & 211 & 20,685 & 32,000 & 2,250 & 220,640 & 90 \\
\hline 4,500 & 316 & 31,028 & 36,000 & 2,531 & 248,220 & 0 \\
\hline 4,500 & 316 & 31,028 & 37,500 & 2,637 & 258,563 & 15 \\
\hline 4,500 & 316 & 31,028 & 37,000 & 2,601 & 255,115 & 30 \\
\hline 4,500 & 316 & 31,028 & 34,000 & 2,390 & 234,430 & 45 \\
\hline 4,500 & 316 & 31,028 & 36,500 & 2,566 & 251,668 & 60 \\
\hline 4,500 & 316 & 31,028 & 35,000 & 2,461 & 241,325 & 75 \\
\hline 4,500 & 316 & 31,028 & 41,500 & 2,918 & 286,143 & 90 \\
\hline
\end{tabular}

roofs to act as compressed beams (Evans, 1941, p. 44; Woodruft, 1966, p. 282-288) so that they fail in compression and not in tension. Furthermore, coal streaks in the rock lower the failure strength (Youash, 1965a, p. 72).

Unconfined tests of roof rock from the Sunnyside No. 1 Mine indicate that it is about two and one-half to three times as strong when the layering is normal to the maximum principal stress as is the Sunnyside coal (tables 3,6). Triaxial compressive tests indicate that the roof rock is about 30 percent stronger at $31,028-\mathrm{kPa}$ $\left(4,500-\mathrm{lbf} / \mathrm{in}^{2}\right)$ confining stress than is the coal at $34,490-\mathrm{kPa}\left(5,000-\mathrm{lbf} / \mathrm{in}^{2}\right)$ confining stress. This increased strength of high confining stress and with layers parallel to the maximum compressive stress probably increases the friction along layering planes and causes mine roofs at Sunnyside to behave as compressed beams (Evans, 1941, p. 449; Woodruff, 1966, p. 282-288); so they fail in compression and not 

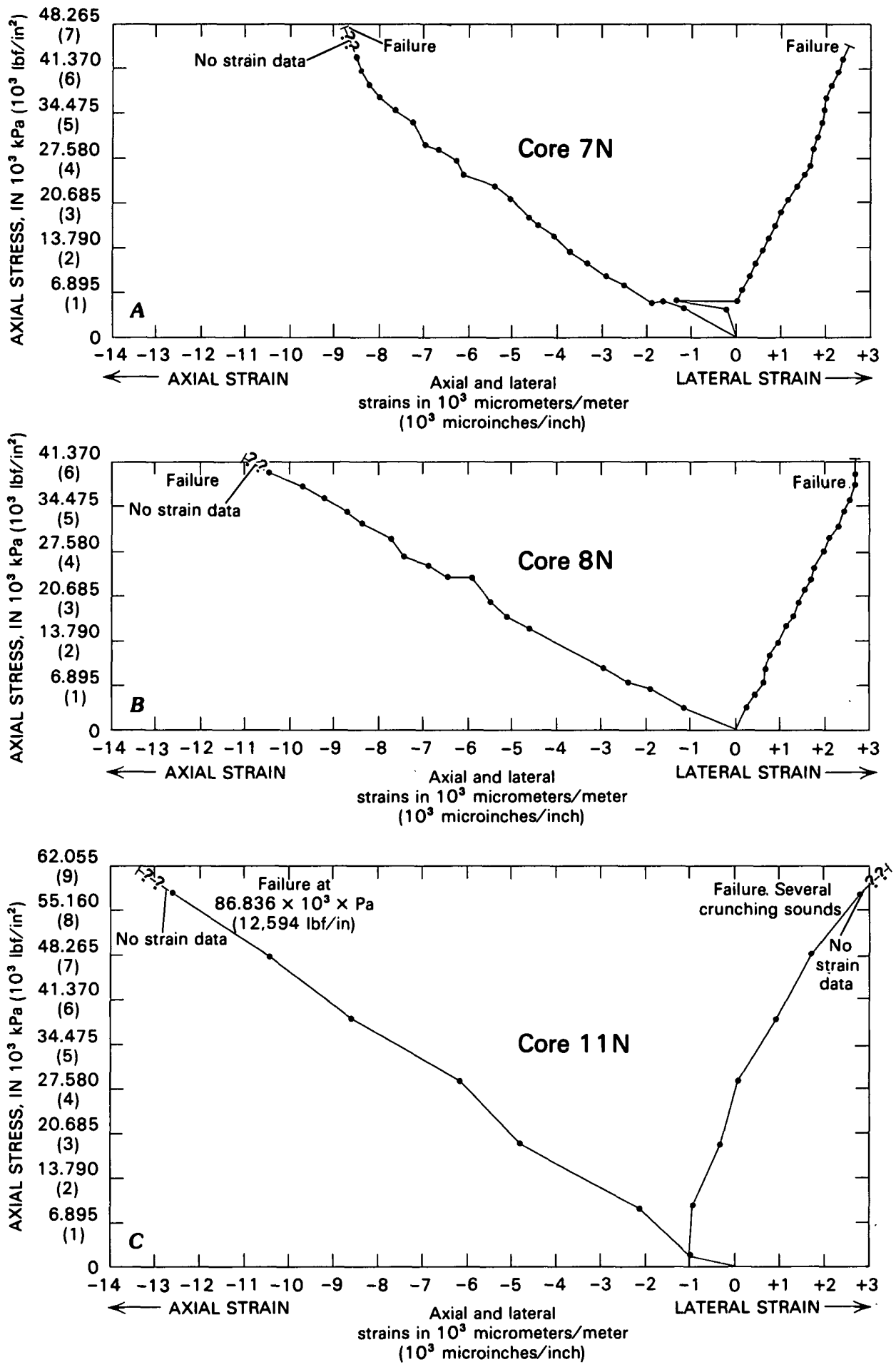

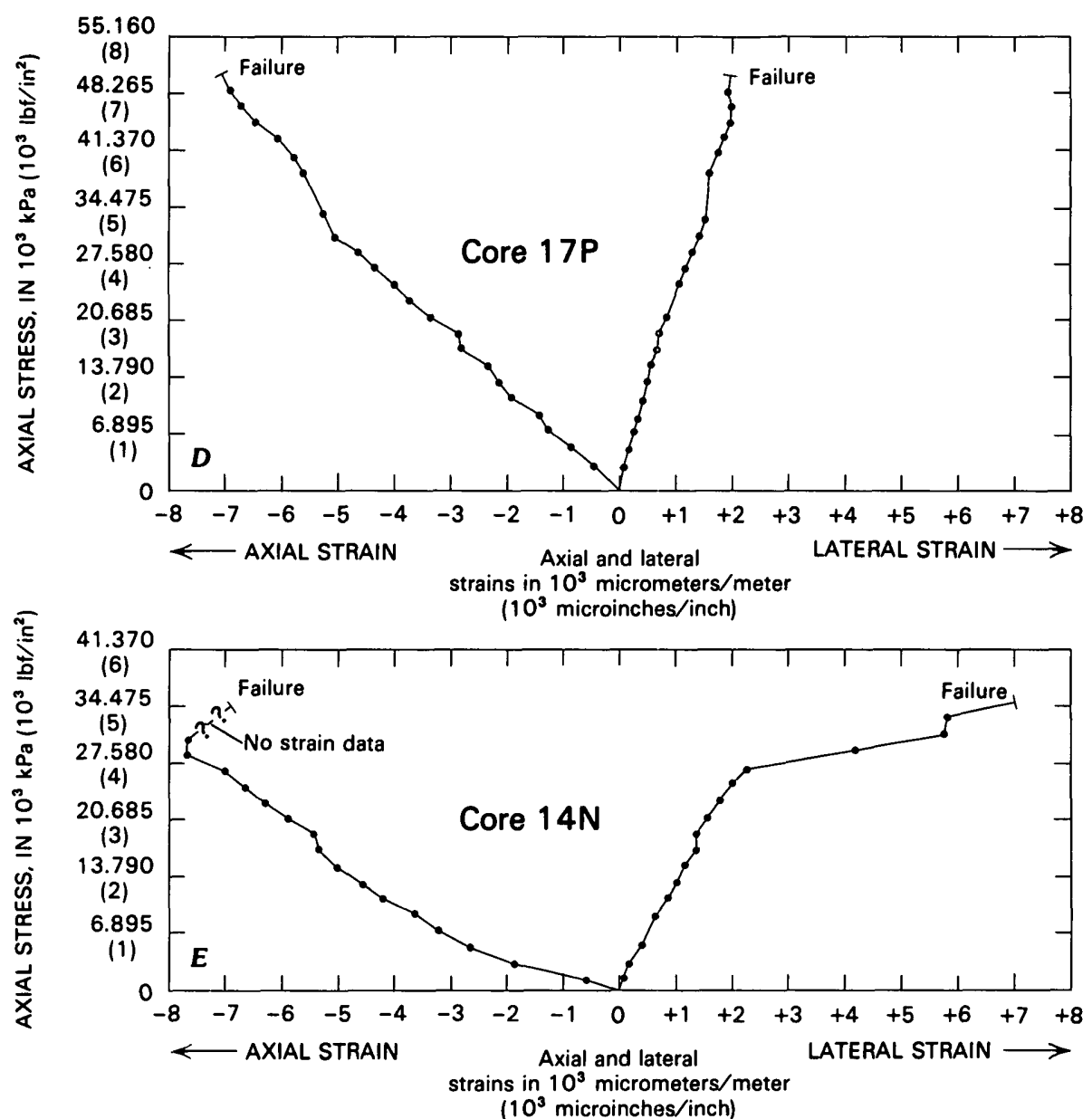

FIGURE 49 (above and facing page).--Stress-strain curves for triaxial compressive tests of coal cores from Sunnyside No. 1 Mine, Utah, using a confining stress of $1,380 \mathrm{kPa}\left(200 \mathrm{lbf} / \mathrm{in}^{2}\right)$ that was held constant throughout all testing. Dots are recorded datum. Dashed line and queries(??) are projected values due to gauge failure. $A$, Core $7 \mathrm{~N}$ (cut normal to bedding in coal), ends free to slip on platens of test machine; $B$, Core $8 \mathrm{~N}$ (cut normal to bedding in coal), ends free to slip on platens of test machine; $C$, Core $11 \mathrm{~N}$ (cut normal to bedding in coal), ends free to slip on platens; $D$, Core 17P (cut parallel to bedding in coal), ends free to slip on platens; $E$, Core $14 \mathrm{~N}$ (cut normal to bedding in coal), ends free to slip on platens. 


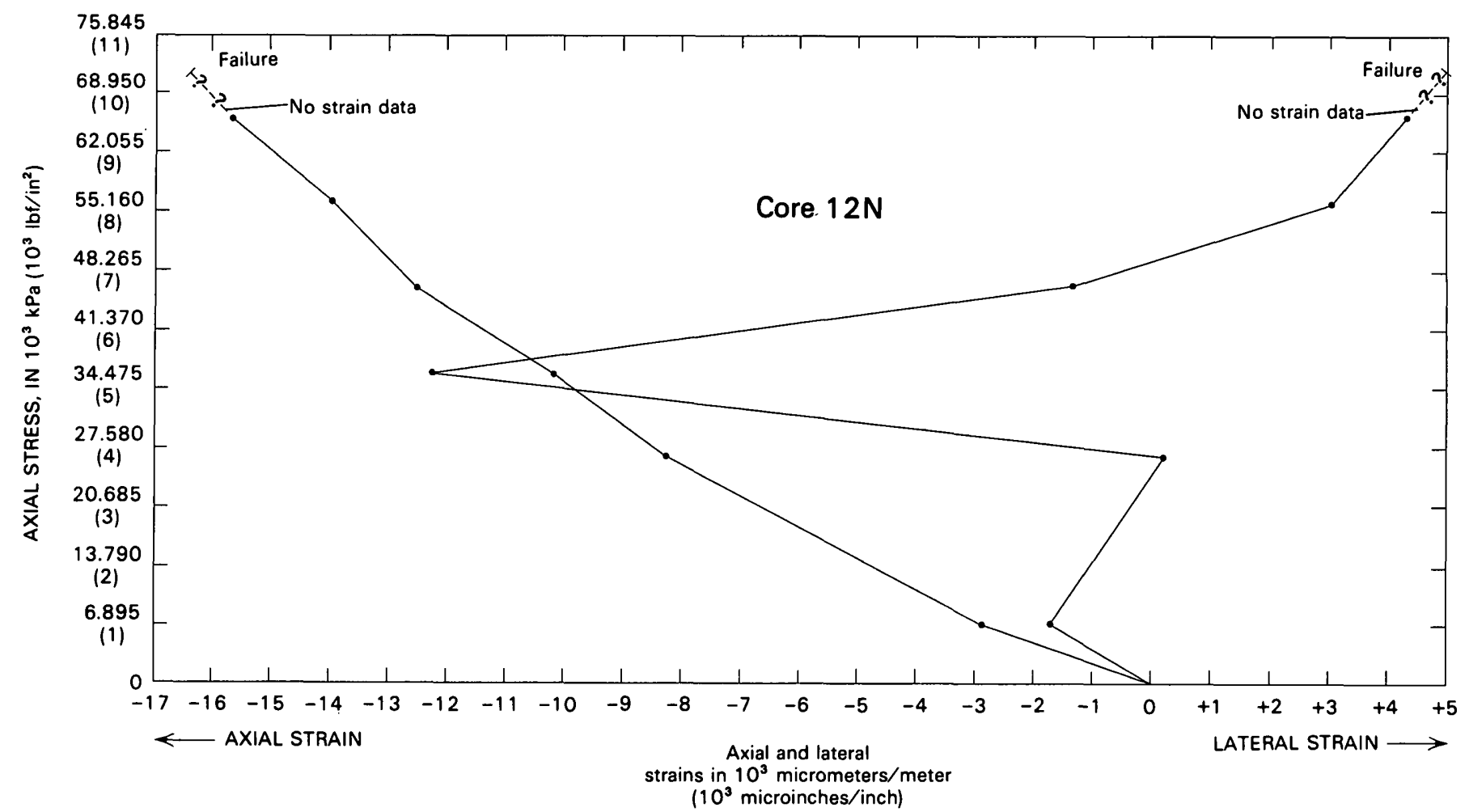

Figure 50.-Stress-strain curve for triaxial compressive test of coal core from Sunnyside No. 1 Mine, Utah, using a confining stress of 6,895 $\mathrm{kPa}\left(1,000 \mathrm{lbf} / \mathrm{in}^{2}\right)$. Core $12 \mathrm{~N}$, cut normal to bedding in coal, ends free to slip on platens. Dots are recorded datum. Dashed line and queries(??) are projected values due to gauge failure.

in tension, even, where nearly vertical joints and fractures cut the roof rocks. Because coal from Medicine Hat, Alberta, Canada, was not as strong as the roof rocks, Jeremic (1981, p. 69-71) recommended leaving coal in mine roofs as protection against failures. Although leaving "top coal" to protect mine roofs was once common practice at Sunnyside, modern methods of roof support using bolts and yieldable steel arches were found to be more effective.

\section{CREEP TESTS}

The creep behavior of coal from the Sunnyside No. 1 Mine was studied in the laboratory by B. K. Barnes. Bars of coal were sawed from a large block. These bars were cut so that their long axes were parallel to the bedding of the coal; they were $10.2 \mathrm{~cm}$ (4 in.) long, $1.27 \mathrm{~cm}(0.5 \mathrm{in}$.) wide, and $0.640 \mathrm{~cm}(0.25 \mathrm{in}$.) thick. Cutting bars of coal to sufficient length was difficult because the coal was brittle, and many broke before the testing was complete. The bars of coal were attached to a steel bar with epoxy and turned so that the coal bars were horizontal; weights of various sizes then were hung vertically from the ends of the coal. Deflections of the coal bars from the horizontal were then measured over long periods of time. Because no environmentally controlled laboratory space was available, the tests were conducted at normal room temperatures and humidities, which undoubtedly contributed inaccuracies to the results. The coal bars were used for the creep tests instead of specimens loaded in direct compression because suitable facilities were not available for the compressive tests. We realize that the behavior of the bars may be different in some respects from the behavior of loaded specimens, as pointed out by Griggs (1939, p. 226-227). Core $4 \mathrm{~N}$ (table 1; fig. 52C) was loaded in a triaxial compressive test as slowly as possible to approximate a creep test, but no difference in modulus or strength was detected as compared to other cores tested at the same confining stresses.

According to Griggs (1939, p. 228) creep in rocks has two components, which he called elastic flow and pseudoviscous flow. Because the behavior of coal may not represent truly elastic deformation, we prefer the term pseudoelastic flow. Because small deflections of some bars of coal are proportional to time (during that part of the creep represented by pseudoviscous flow), as is the compression of a viscous cylinder under axial load, the deflection of the coal bars is similar to the strain of a loaded cylinder-although bars are more susceptible to environmental changes than are loaded cylinders (Griggs, 1939, p. 226-227). Griggs (1939, p. 228) represented the creep of loaded cylinders as a function of time by the equation: 


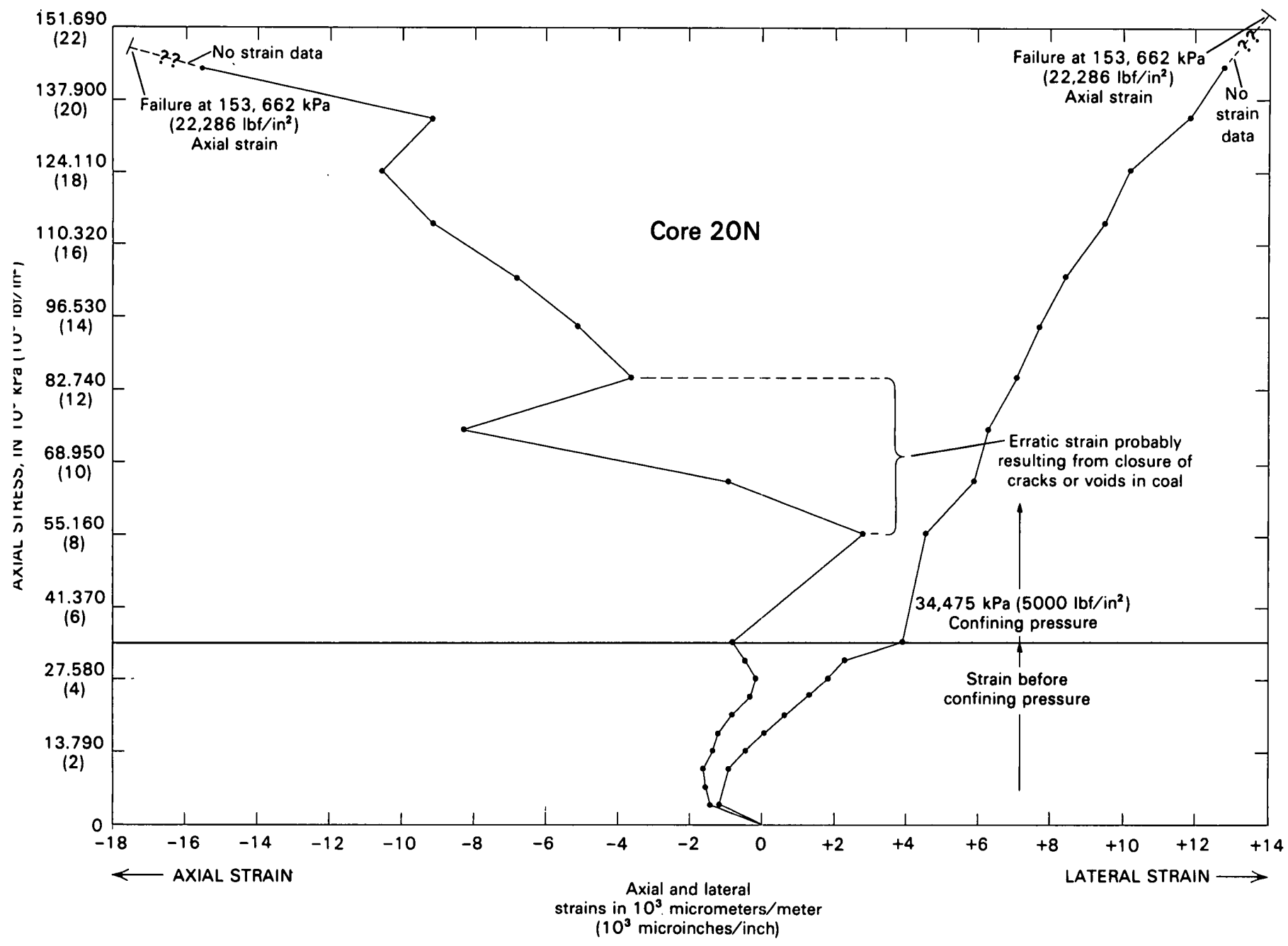

FIGURE 51.-Stress-strain curves for triaxial compressive test of coal core from Sunnyside No. 1 Mine, Utah, using a confining stress of 34,480 $\mathrm{kPa}\left(5,000 \mathrm{lbf} / \mathrm{in}^{2}\right)$. Dots are recorded datum. Dashed line and queries(??) are projected values due to gauge failure.

$$
S=A^{\prime}+B(\log t)+C t
$$

in which $B(\log t)$ represents the elastic flow and $C t$, the pseudoviscous flow. The term $A^{\prime}$ in the equation represents the early part of the deformation of cylinders, which he stated (Griggs, 1939, p. 228) to be of no importance in long-term tests.

The deflections of cantilever bars of coal, however, can adequately measure the creep characteristics of coals if the responses of the bars to environmental changes are considered (C. D. Pomeroy, British National Coal Board, written commun., 1955). Pomeroy used an equation similar to Griggs' for cylinders (1939, p. 228) to represent the creep of cantilever bars:

$$
d=A_{1}+B_{1}(\log t)+c_{1} t
$$

In this equation $d$ is the deflection, and $A_{1}$ is a term representing the first part of the deflection, before pseudoviscous deformation begins; $A_{1}$ is determined by measuring the point on the vertical axis of the graphs at which a horizontal line from the beginning of the pseudoelastic portion of the creep curves intersects the vertical axis. Also in the equation, $t$ is elapsed time, $B_{1}(\log t)$ generally is the straight-line part of the curves plotted on semilogarithmic graphs (figs. 56-60) representing the pseudoelastic or nearly recoverable portions of the creep deformations when the pseudoviscous deformation is very small, and $c_{1} t$ is a term representing the slope of the pseudoviscous portions of the creep curves (indicating a constant rate of creep) when the pseudoelastic strain is very small. The equation does not adequately describe the early parts of the deformation because the logarithmic part approaches minus infinity as time approaches zero 


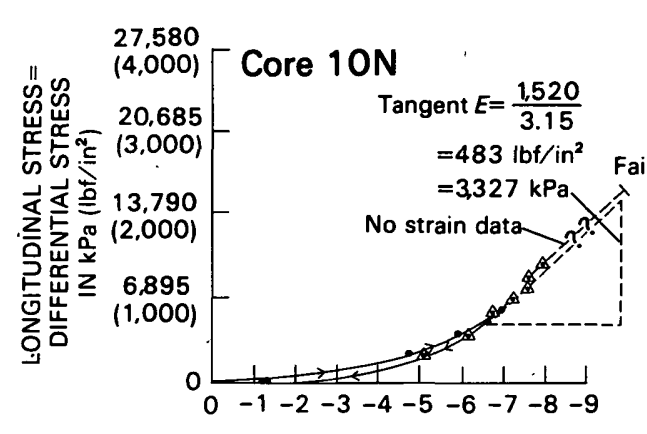

$\boldsymbol{A}$

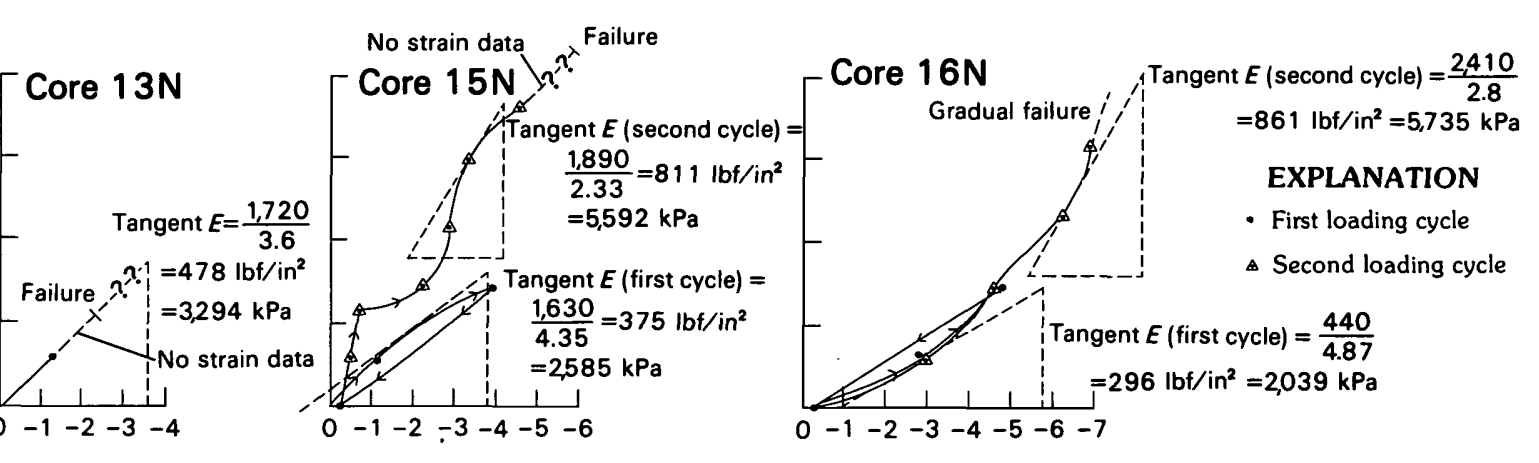

AXIAL STRAIN, IN $10^{3}$ MICROMETERS/METER

(MICROINCHES/NCH)

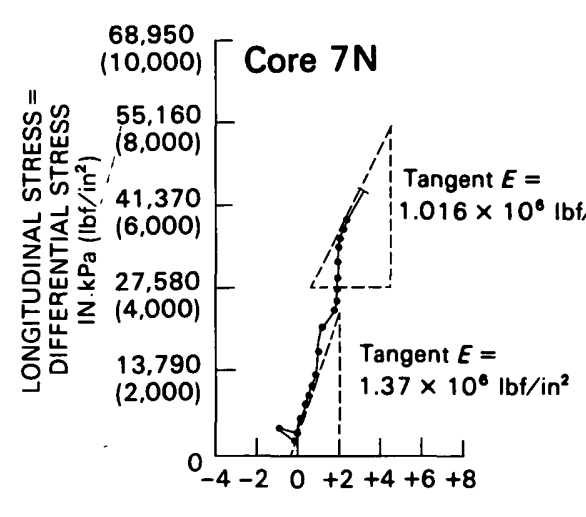

B
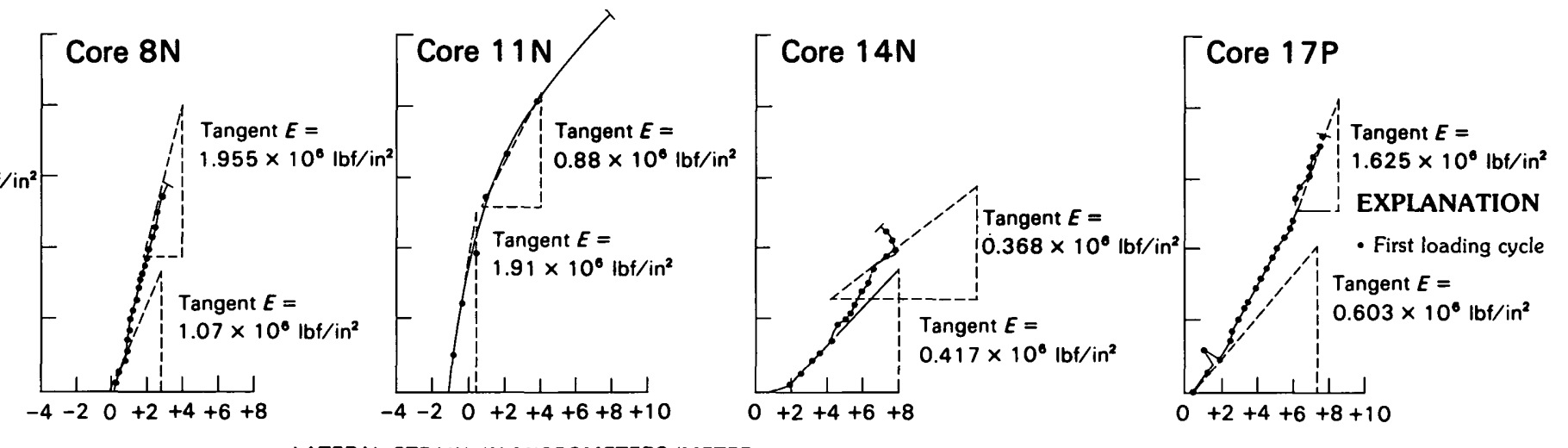

LATERAL STRAIN, IN MICROMETERS/METER 


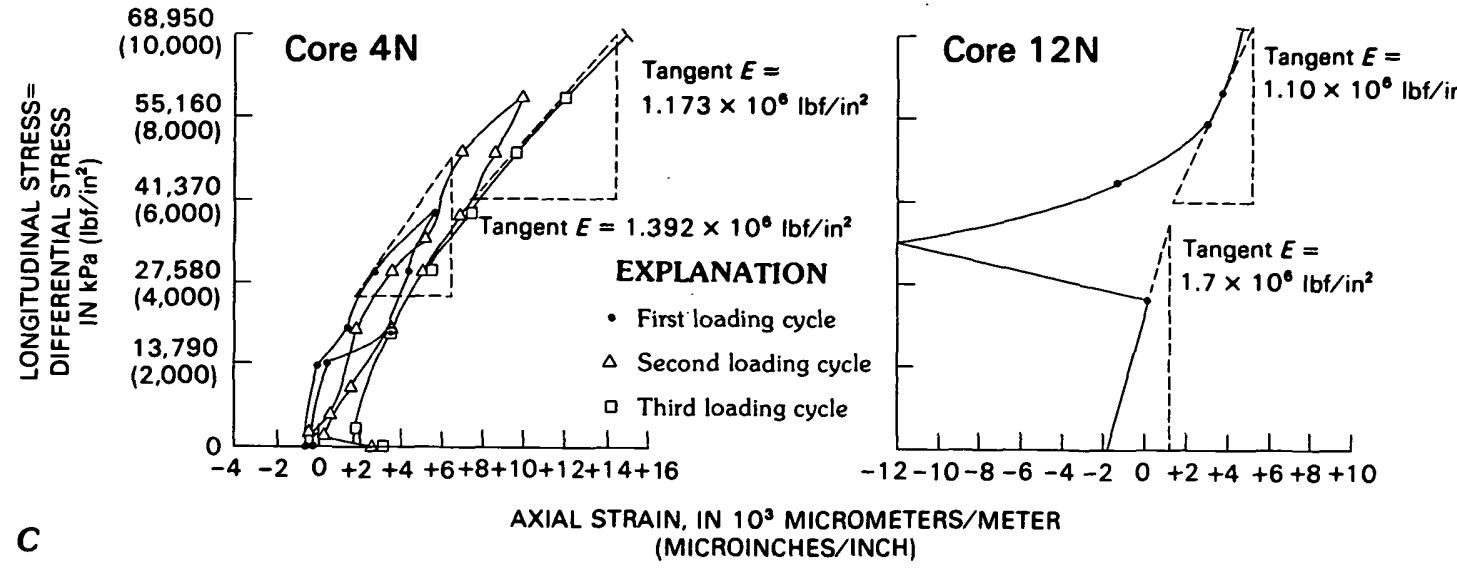

FIGURE 52.-Triaxial compressive test results of coal failure. $A$, Cores tested in unconfined compression, in cores from Sunnyside No. 1 Mine, Utah, showing up to two loading cycles. $B$, Cores tested with 1,379 axial strain on horizontal axis plotted against $\mathrm{kPa}\left(200 \mathrm{lbf} / \mathrm{in}^{2}\right)$ confining stress in one loading cycle differential (axial minus lateral) stress. Tangent $C$, Cores tested with $6,895 \mathrm{kPa}\left(1,000 \mathrm{lbf} / \mathrm{in}^{2}\right)$ moduli $(E)$ determined graphically on each curve. confining stress, in up to three loading cycles. $D$

Dots are recorded datum points. Dashed lines and Cores tested with $34,480 \mathrm{kPa}\left(5,000 \mathrm{lbf} / \mathrm{in}^{2}\right)$ confining queries(??) are projected values due to gauge stress, in one loading cycle.

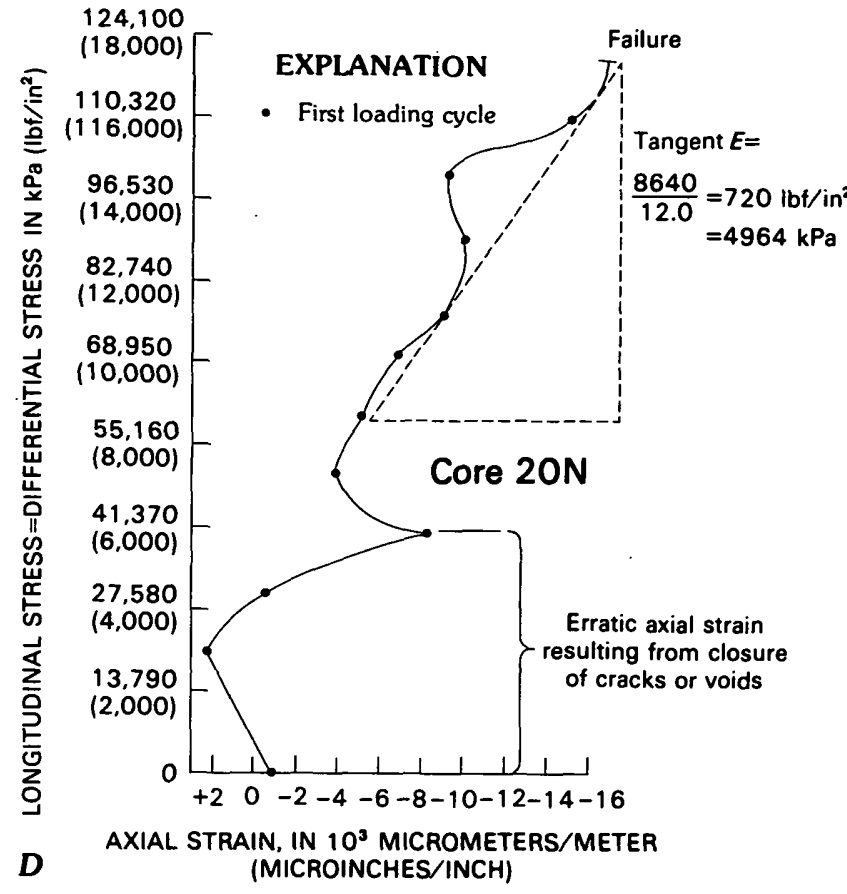

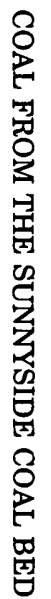




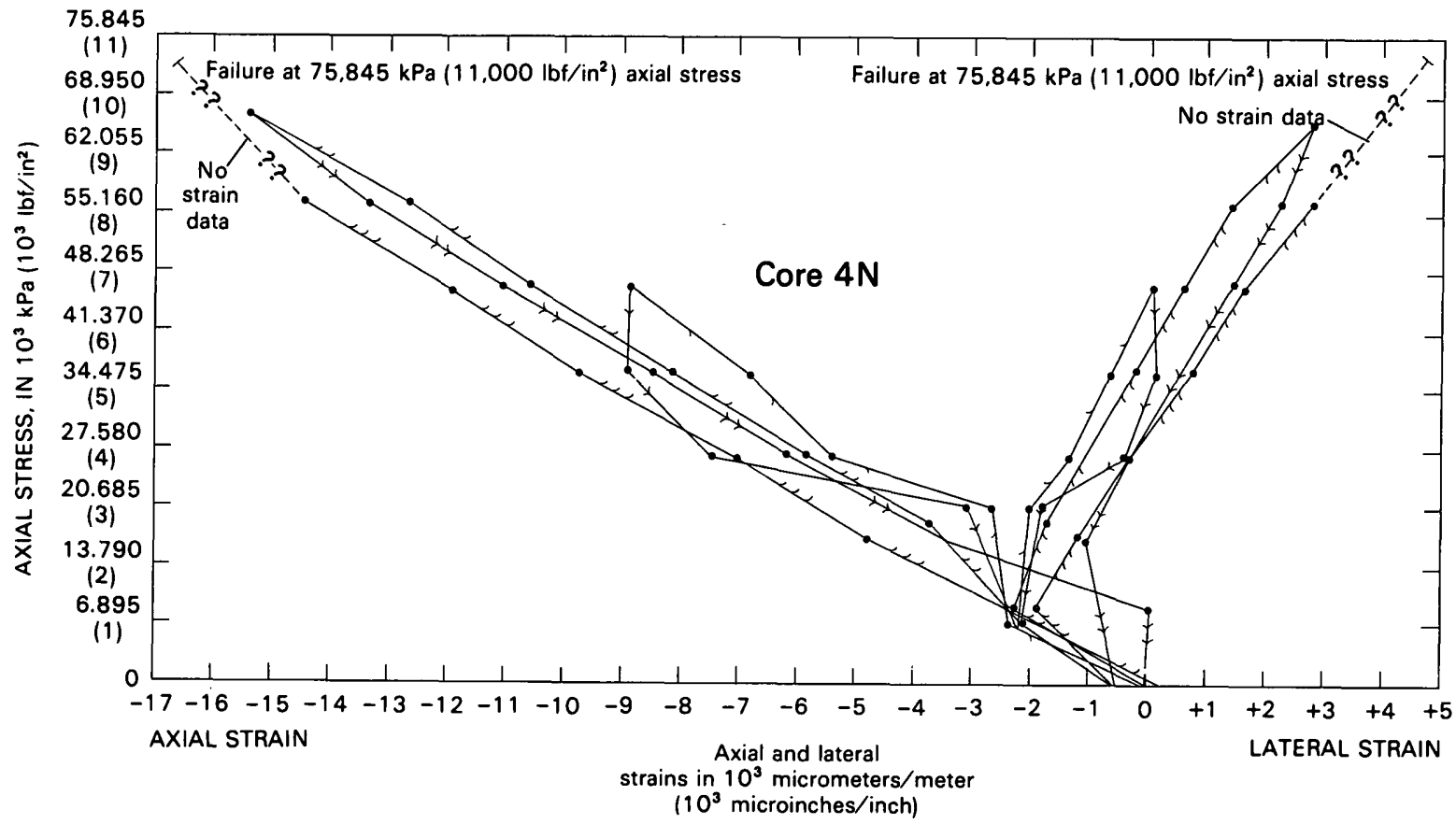

FIGURE 53.-Stress-strain curve for triaxial compressive test of coal core from Sunnyside No. 1 Mine, Utah, subjected to repeated cycles of loading at a confining stress of $6,895 \mathrm{kPa}\left(1,000 \mathrm{lbf} / \mathrm{in}^{2}\right)$. Core $4 \mathrm{~N}$, cut normal to bedding of coal. Half arrows indicate increasing stress; full arrows indicate decreasing stress. Number of arrows on each line segment corresponds to number of loading cycle. Dots are recorded datum points. Dashed line and queries(??) are projected values due to gauge failure.

(Griggs, 1939, p. 228). Furthermore, the term $A_{1}$ (describing the earliest parts of the deformation) is difficult to evaluate. We do not agree with Griggs (1939, p. 228) and Pomeroy (written commun., 1955) that the earliest parts of the deformations are not important to the long-term results. When plotted on a linear time scale (fig. 55), the deflection of a bar loaded with $95 \mathrm{~g}(3.35 \mathrm{oz})$ showed a rapid and linear initial deflection rate in the first $1 / 2$ hour. Between $1 / 2$ and 4 hours the deflection gradually decreased. After the first 4 hours, the bar deflected at a uniform rate, yielding a nearly straight-line curve, until slightly more than 24 hours had elapsed. Thus, the first $1 / 2$ hour of the deflection curve (fig. 55) may represent initial, nearly elastic deformation which gradually decreases with an increase in pseudoviscous deformation until 4 hours have elapsed. After 4 hours elapsed, the bar deformed by pseudoviscous creep until 1 day elapsed. Neither Griggs nor Pomeroy considered the deformation prior to 1 day's elapsed time. The term $A_{1}$, therefore, probably should include both elastic and time-dependent pseudoviscous deformation; the pseudoviscous portion increases rapidly near the end of the time represented by $A_{1}$. The $B_{1}(\log t)$ term in the equation also approaches infinity as time approaches infinity, but this is not important to our bar tests because of the short lengths of time and because environmental changes mask any small late deflections.

The deflection curves we obtained (figs. 56-60) are more complex than the ones shown by Griggs (1939) and by C. D. Pomeroy (written commun., 1955). Beyond an elapsed time of about 1 day, our curves seem to represent combined and simultaneous pseudoviscous and pseudoelastic deformation (representing the $B_{1}(\log t)$ and $c_{1} t$ terms of the equation). The proportional amounts of each of these terms that describe individual deformation curves change with increasingly large amounts of elapsed time.

Deflections of clamped cantilever bars can be used to determine the elastic modulus of the material from which the bars are made. The following discussion is adapted from Singer $(1951$, p. 212-213). Let $L$ be the length of the beam, $H$ the height, and $B$ the width; total weight of the beam is $W$. Deflection $(d)$ of the beam results from the sum of the concentrated load on the end of the beam $(P)$ and a distributed load represented by the weight of the beam $(W)$. The deflection of the beam after loading will then be represented by the following equation:

$$
d=\frac{W L^{3}}{8 E I}+\frac{P L^{3}}{3 E I},
$$



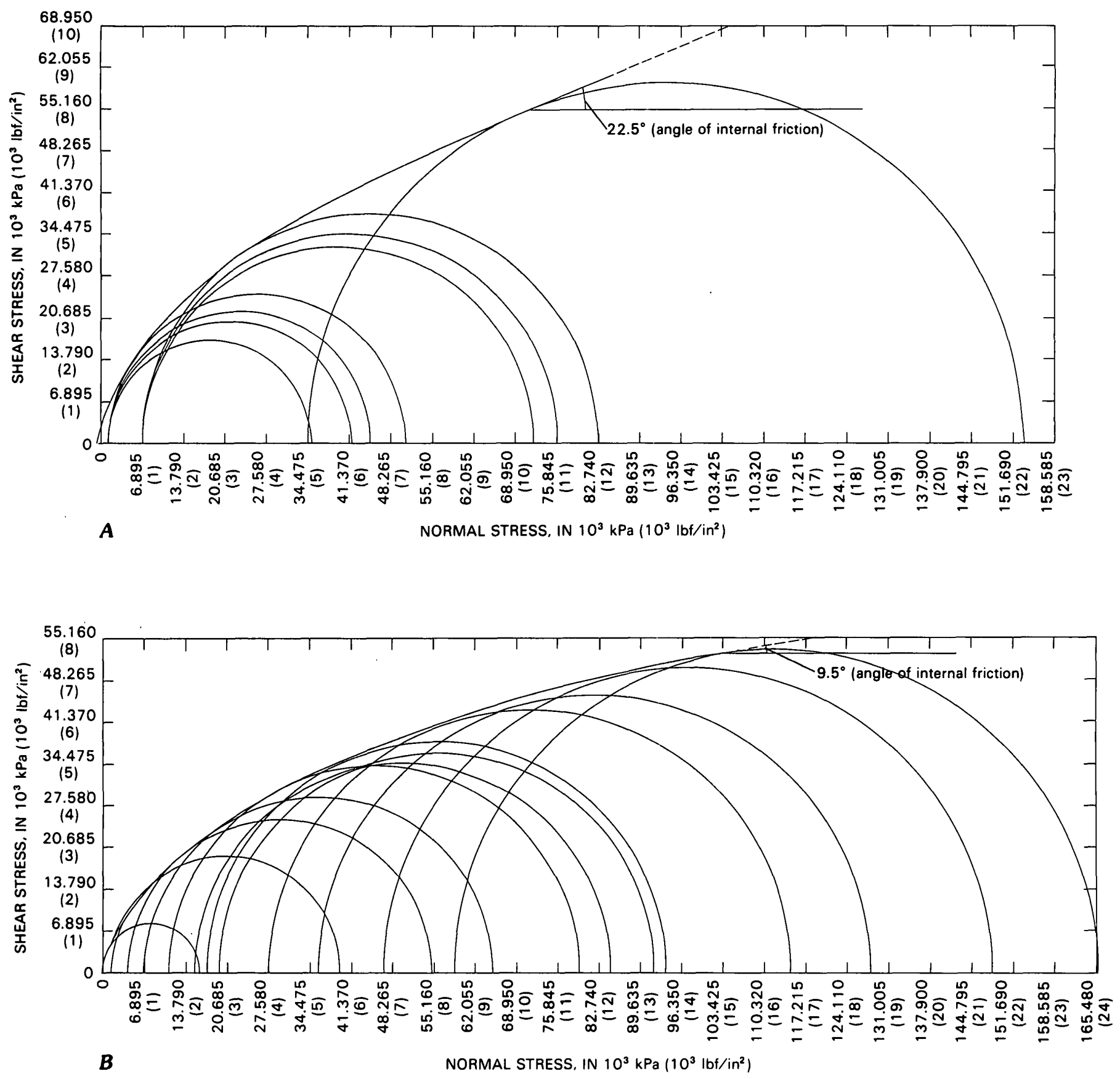

FIGURE 54.-Mohr diagrams for cores from Sunnyside coal bed. A, From the Sunnyside No. 1 Mine, Utah, and $B$, from the Sunnyside No. 3 Mine, Utah. Data from F.L. Gaddy, E.R. Rodriguez, and T.C. Miller (written commun., 1959).

where

$E$ is the elastic modulus of the material and $I$ is the moment of inertia of the beam. The elastic modulus, therefore, can be determined by

$$
d=\frac{L^{3} \times(3 W+8 P)}{24 d I}
$$

which, for beams with rectangular cross sections, is equivalent to

$$
E=\frac{(3 W \pm 8 P) L^{3}}{2 d B H^{3}}
$$

where

$B$ is the width and $H$ is the height of the beam. 
TABLE 7.-Measured deflections of coal bars and computed moduli of elasticity

[Analyst: B. K. Barnes. Weight of bars (11.03 g) estimated from average densities of coal (table 1). $P$ is amount of weight added to end of bar, $d_{0}$ is deflection measured immediately after bar was weighted, $E_{\mathrm{o}}$ is elastic modulus computed from initial deflection $\left(d_{\mathrm{o}}\right), d_{2}$ is deflection after 2 hours, and $E_{2}$ is modulus computed from $d_{2}$ ]

\begin{tabular}{|c|c|c|c|c|c|c|c|c|c|}
\hline \multicolumn{2}{|c|}{$P$} & \multicolumn{2}{|c|}{$d_{\mathrm{o}}$} & \multicolumn{2}{|c|}{$E_{\mathrm{o}}$} & \multicolumn{2}{|c|}{$d_{2}$} & \multicolumn{2}{|c|}{$E_{2}$} \\
\hline $\begin{array}{c}\text { In grams } \\
\text { (measured) }\end{array}$ & $\begin{array}{c}\text { In ounces } \\
\text { (calculated) }\end{array}$ & $\begin{array}{l}\text { In inches } \\
\text { (measured) }\end{array}$ & $\begin{array}{c}\text { In millimeters } \\
\text { (calculated) }\end{array}$ & $\begin{array}{l}\text { In } 10^{3} \\
\text { lbf/in }\end{array}$ & $\begin{array}{c}\text { In } 10^{8} \\
\mathrm{kPa}\end{array}$ & $\begin{array}{l}\text { In inches } \\
\text { (measured) }\end{array}$ & $\begin{array}{c}\text { In millimeters } \\
\text { (calculated) }\end{array}$ & $\begin{array}{l}\text { In } 10^{3} \\
\mathrm{lb} / \mathrm{in}^{2}\end{array}$ & $\begin{array}{c}\text { In } 10^{6} \\
\mathrm{kPa}\end{array}$ \\
\hline 85 & 3.0 & 0.0096 & 0.2438 & 66.3 & 0.457 & 0.0196 & 0.4978 & 32.5 & 0.224 \\
\hline 85 & 3.0 & .0068 & .1727 & 93.6 & .645 & .0196 & .3835 & 45.2 & .291 \\
\hline 95 & 3.4 & .0183 & .4648 & 38.7 & .267 & .0189 & .4801 & 37.5 & .258 \\
\hline 95 & 3.4 & .0111 & .2819 & 63.8 & .440 & .0126 & .3200 & 56.2 & .387 \\
\hline 105 & 3.7 & .0106 & .2692 & 73.5 & .507 & .0160 & .4064 & 48.7 & .336 \\
\hline 115 & 4.1 & .0069 & .1753 & 123.5 & .850 & .0069 & .1753 & 112.9 & .779 \\
\hline 115 & 4.1 & .0326 & .8280 & 26.1 & .180 & .0349 & .8865 & 24.4 & .168 \\
\hline 125 & 4.4 & .0089 & .2261 & 103.6 & .714 & .0159 & .4039 & 17.0 & .117 \\
\hline 125 & 4.4 & .0089 & .2261 & 103.6 & .714 & .0180 & .4572 & 15.0 & .104 \\
\hline 135 & 4.8 & .0106 & .2692 & 100.5 & .693 & .0204 & .5182 & 48.7 & .309 \\
\hline 135 & 4.8 & .0160 & .4064 & 66.6 & .459 & .0260 & .6604 & 38.2 & .263 \\
\hline 145 & 5.1 & .0139 & .3277 & 82.5 & .569 & .0209 & .5309 & 50.9 & .351 \\
\hline 155 & 5.5 & .0334 & .8484 & 34.5 & .235 & .0407 & 1.0338 & 24.4 & .168 \\
\hline 155 & 5.5 & .0189 & .4801 & 60.1 & .415 & .0241 & .6121 & 47.2 & .325 \\
\hline 165 & 5.8 & .0291 & .7391 & 41.5 & .286 & .0358 & .9093 & 33.7 & .233 \\
\hline 165 & 5.8 & .0135 & .3429 & 89.5 & .617 & .0218 & .5537 & 55.4 & .382 \\
\hline 175 & 6.2 & .0221 & .5613 & 57.9 & .399 & .0250 & .6350 & 51.2 & .353 \\
\hline 175 & 6.2 & .0323 & .8204 & 39.6 & .273 & .0337 & .8560 & 38.0 & .262 \\
\hline
\end{tabular}

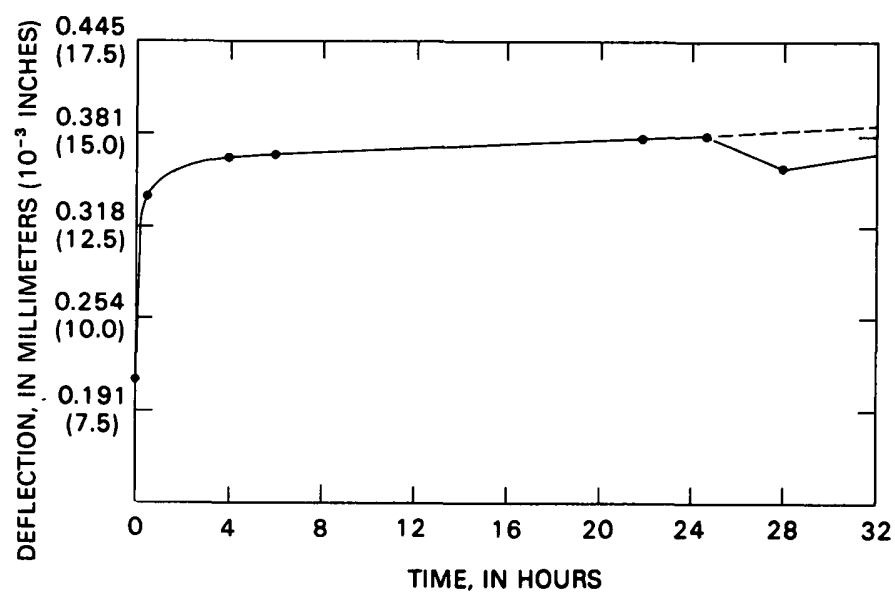

Figure 55.-Deflection of a coal bar (bar A in fig. 56) from Sunnyside No. 1 Mine, weighted with $95 \mathrm{~g}$ (3.5 oz), during first 29 hours versus linear time scale (dashed line is generalized curve that intersects actual plotted points at about 36 hours). Compare with figure 56.

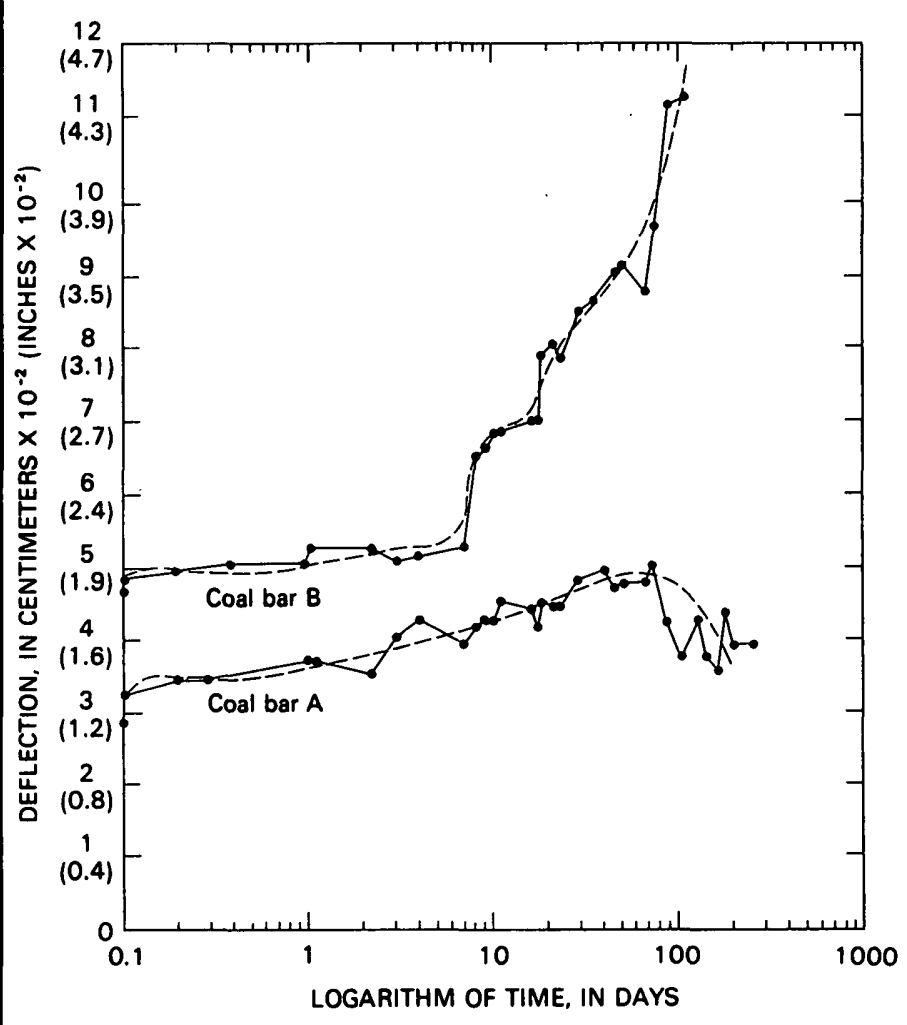

FIGURE 56.-Deflection of two bars of coal from Sunnyside No. 1 Mine,

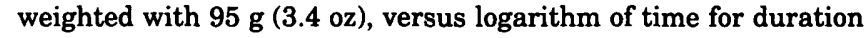
of test. Dashed curves fitted mechanically using French curves, to show general trends of deflections. 


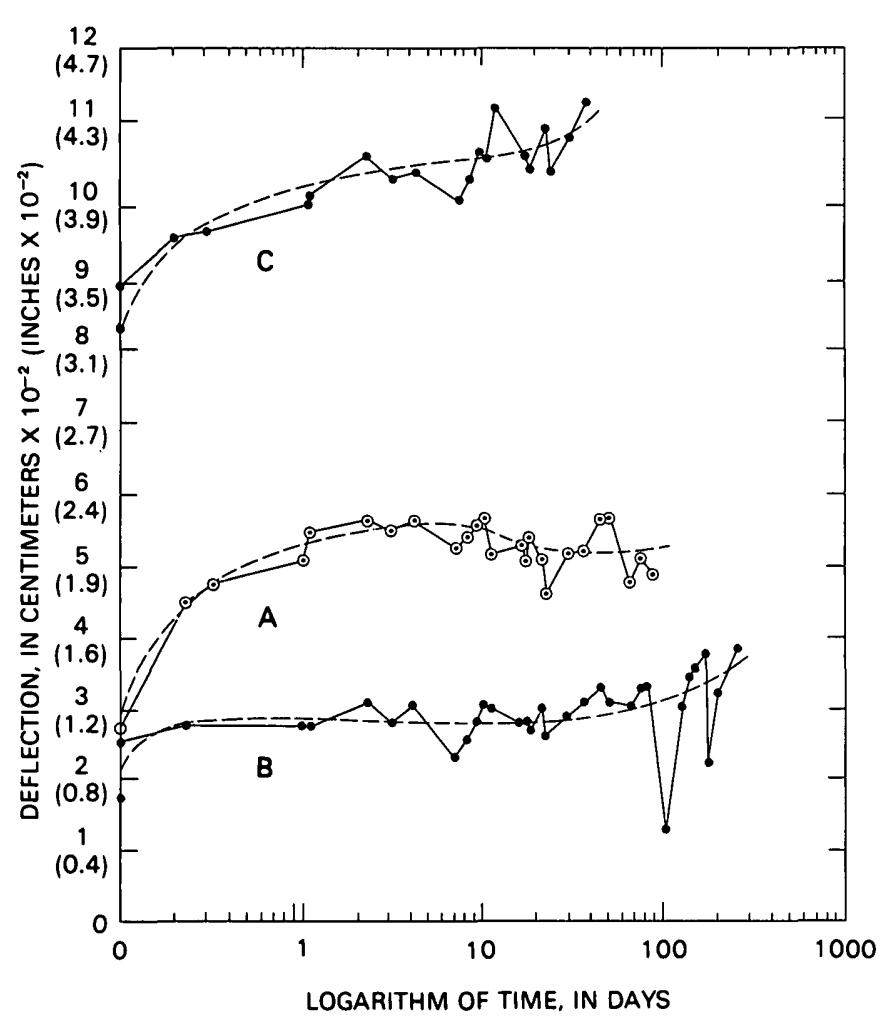

FIGURE 57.-Deflection of bars of coal from Sunnyside No. 1 Mine, Utah, weighted with $105 \mathrm{~g}$ ( $3.7 \mathrm{oz}$ ) (A, open circles about dots) and $115 \mathrm{~g}(4.1 \mathrm{oz})$ (B and $\mathrm{C}$, dots), plotted against logarithm of time. Dashed curves mechanically fitted using French curves, to show general trends of deflections.

All bars used in our tests were of the same size, constituting a volume of $8.29 \mathrm{~cm}^{3}\left(0.51 \mathrm{in}^{3}\right)$. Using an average density of $1.33 \mathrm{~g} / \mathrm{cm}^{3}\left(0.05 \mathrm{lb} / \mathrm{ft}^{2}\right)$, determined from table 1 , the average weight of the coal bars was $11.03 \mathrm{~g}(0.389 \mathrm{oz})$. Elastic moduli for deformation of the bars shown in figures 56-60, calculated from equation 1 , are shown in table 7 . The elastic moduli $\left(E_{\mathrm{o}}\right)$ calculated from the deflection that occurred as soon as the bars were weighted $\left(d_{\mathrm{o}}\right)$ are close to the static secant modulus deteremined for core $10 \mathrm{~N}$ tested in unconfined compression (table 1). The modulus of core $10 \mathrm{~N}$, however, was more than five times less than the modulus of other cores of coal from the Sunnyside No. 1 Mine (table 1) and was about three times less than the secant modulus determined from the coal cores from the Sunnyside No. 3 Mine (table 2) (F. L. Gaddy, E. R. Rodriguez, and T. C. Miller, written commun., 1959). The elastic modulus determined from deflection of the coal bars was about one-tenth the moduli Scheibner (1979, p. 24-25) calculated for coal from the Sunnyside No. 1 . The lower moduli probably resulted from the different testing methods used in these various reports, but the variations in secant moduli for unconfined cores in table 1 suggest that, although the moduli are of the same order of magnitude, actual variations exist in the coal.

Elastic moduli of the coal bars determined from deflections measured 2 hours after loading $\left(E_{2}\right.$ in table 7) generally are less than the moduli determined from the initial loading $\left(E_{\mathrm{o}}\right)$, probably because the deflection after 2 hours is increased by the onset of nonelastic deformation; therefore, the measurements include both elastic and nonelastic moduli.

The curves in figures 56-59 in general show an initially rapid deflection after being weighted. Following this rapid initial deflection, most curves, for example, $\mathrm{A}$ in figure 56, show a long, almost linear increase in deflection with the logarithm of time (pseudoelastic) for the first 8-50 days, followed by nonlinear deflection with the logarithm of time. Coal bars with the same weights, however, did not always behave similarly. Bar B, represented by curve B in figure 56 , showing almost twice the initial rapid deflection of the one represented by bar $A$, after about 3 days began to deform pseudoelastically but at a much increased rate. A coal bar weighted with $105 \mathrm{~g}$ ( $\mathrm{A}$ in fig. 57) after about 3 days of elapsed time showed an almost logarithmic decrease in deflection with the logarithm of time. Some bars weighted with the same mass, showed as much as four times the deflection of others ( $B$ and $C$ in fig. 57). Generally, bars weighted with heavy masses (C, D, and $E$ in fig. 58 and and $C$ in fig. 59) began to deflect at increasingly rapid rates (pseudoviscous deformation?) after about 10-30 days. A few bars (A in fig. 57 and B in fig. 59) showed little or no increase in deflection with time after the initially rapid deformation, probably indicating that the coal did not creep markedly. The few bars that showed decreasing deflection with time may indicate the effects of chemical changes within the coal, either as a result of stress or of temperature or humidity changes in the laboratory. The nearly cyclic variations in deflection (shown by solid lines in figs. 56-60) at about the same times for different coal bars probably result either from environmental changes or from accidental disturbances in the laboratory.

Several bars of coal, after being loaded for several days, were unloaded to observe the recovery from deflection and also to investigate the behavior of the coal upon second loadings. After being weighted with $85 \mathrm{~g}(3.0 \mathrm{oz})$ for 7 days, one bar was completely unloaded (A in fig. 60). About one-half of the total deflection of this bar was recovered immediately; the remainder was recovered at a nearly uniform rate until about 98.5 days, at which time the bar was closer to its original configuration than it had been at the initial measurement about 0.27 days after weighting. Another bar also weighted with $85 \mathrm{~g}(3.0 \mathrm{oz})$ was 


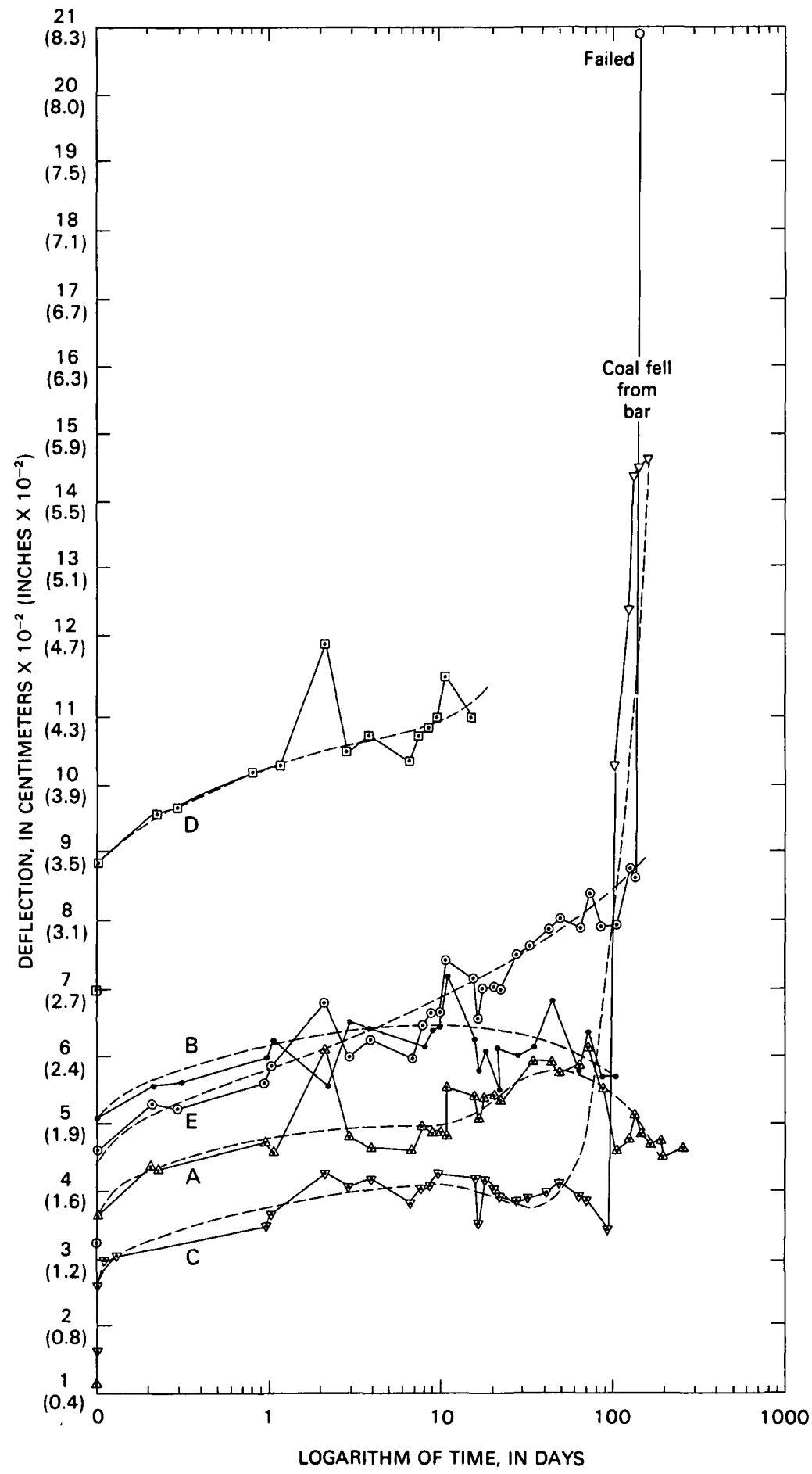

Figure 58.-Deflection of bars of coal from Sunnyside No. 1 Mine, plotted against logarithm of time. A (open triangles (points up) about dots) weighted with

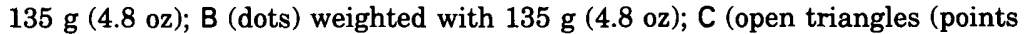
down) about dots) weighted with $145 \mathrm{~g}(5.1 \mathrm{oz})$; $\mathrm{D}$ (boxes about dots) weighted with $155 \mathrm{~g}(5.5 \mathrm{oz})$; and $\mathrm{E}$ (circles about dots) weighted with $155 \mathrm{~g}(5.5 \mathrm{oz})$. Dashed curves are mechanically fitted using French curves to show general trends of deflections. 


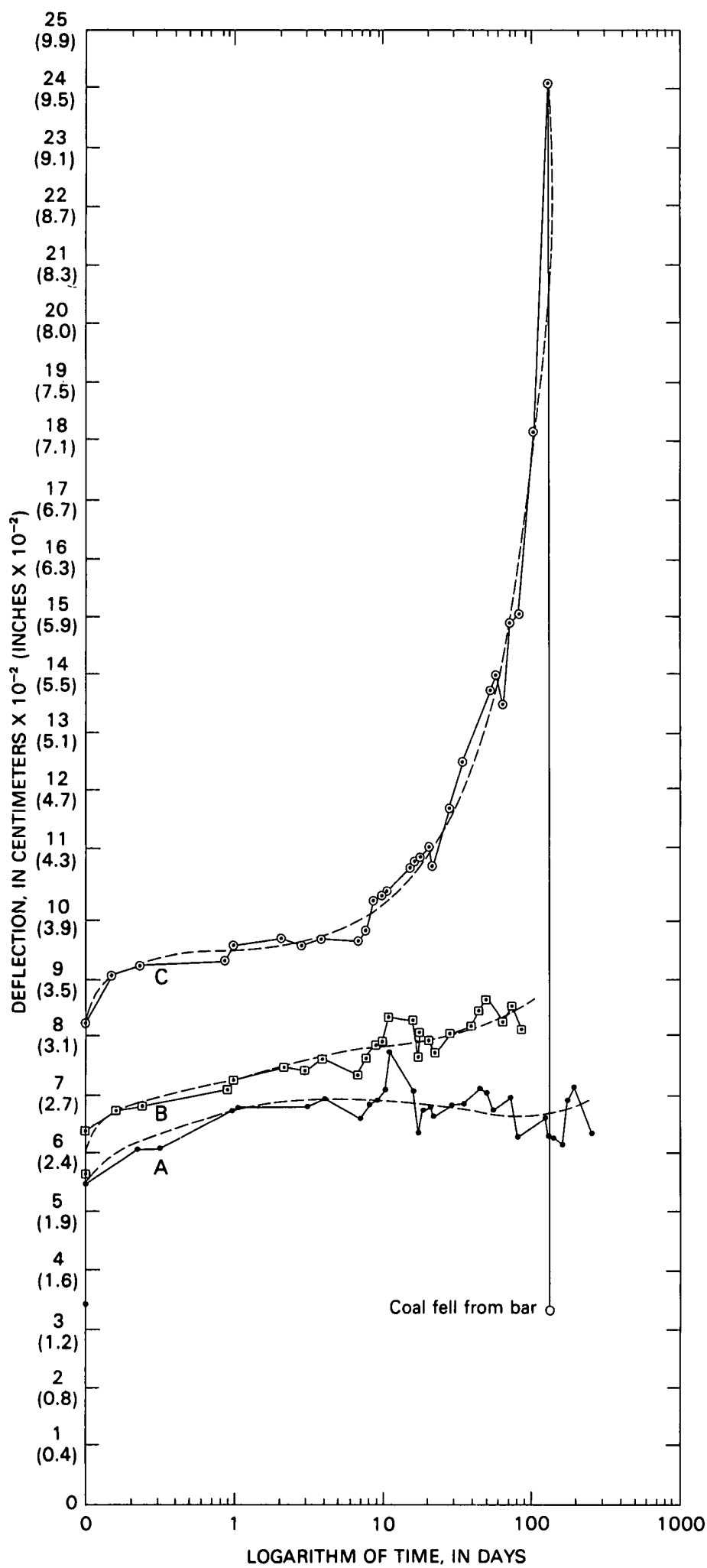

Figure 59.-Deflection of bars of coal from Sunnyside No. 1 Mine, weighted with $165 \mathrm{~g} \mathrm{(5.8} \mathrm{oz)} \mathrm{(A,} \mathrm{dots)} \mathrm{and} 175 \mathrm{~g} \mathrm{(6.2} \mathrm{oz)} \mathrm{(B,} \mathrm{open} \mathrm{boxes}$ about dots and $C$, open cirles about dots), plotted against logarithm of time. Dashed curves mechanically fitted using French curves, to show general trends of deflections. 
unloaded at about 10.2 days. After rapidly recovering about 20 percent of its deflection, this bar was reloaded at about 10.8 days; when reloaded, the bar showed no further creep (B in fig. 60). A third bar weighted with

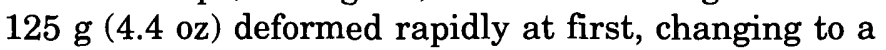
much slower deformation rate at about 0.3 days. This bar was unloaded at 10.1 days and immediately began to recover the slow deformation. When reloaded at about 10.8 days, after recovering the deformation lost during unloading, the coal continued to deform at a slightly higher rate than before unloading, changing gradually to a slower rate than before unloading (C in fig. 60). The deformation of the bar weighted with $125 \mathrm{~g}(4.4 \mathrm{oz})$ was nearly the same as the deformation of one bar weighted with $85 \mathrm{~g}(3.0 \mathrm{oz})$ ( $B$ and $C$ in

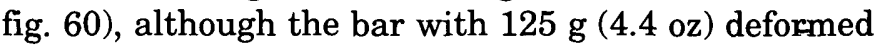
at slightly less deflection.

One coal core (core $4 \mathrm{~N}$, table 1) from the Sunnyside No. 1 Mine was subjected to three cycles of loading during triaxial testing under $6,895-\mathrm{kPa}\left(1,000-1 \mathrm{bf} / \mathrm{in}^{2}\right)$ confining stress (fig. 49). In order to test the creep response of the coal, loading and unloading rates were much slower than those normally used. Although the slow loading and unloading rates yielded larger hysteresis loops than those of samples tested with rapid loading and unloading rates, the resulting stressstrain curves for this test are not markedly different from curves for other samples from the Sunnyside No. 1 Mine that were tested normally at higher rates and loadings. The test was unsuccessful in yielding creep information that could be correlated with the tests of deflection of weighted coal bars because the amount of hysteresis was very close to the amount of hysteresis shown by other samples tested at the same confining stress but with normal loading rates (fig. 49).

\section{CHANGES IN CHEMICAL COMPOSITION RELATED TO STRESSES IN COAL}

Triaxial compressive testing of coal cores from Sunnyside No. 1 and Sunnyside No. 3 Mines revealed small differences in strengths of cores that failed under the same confining stresses (fig. 61). Although these differences were so small that they might have been the results of experimental error, we also considered other possibilities. To do this, infrared spectral analyses were run on various major megascopic types of coal selected from some of the cores in order to measure their contents of major organic-chemical constituents. Detailed discussions of infrared analytic techniques are given by Friedel and Queiser $(1956,1966)$. Results of our analyses indicate either that some of the constituents of vitrain are particularly sensitive to changes in stress or that the failure strengths of some samples are sensitive to variations in chemistry. The constituents most related to these variations are the amounts of benzene-ring compounds and the amounts of kaolin in vitrains of the cores.

Using infrared spectra, we analyzed vitrains, represented by points in figure 61 , in some of the cores from the Sunnyside No. 3 Mine. The amplitudes of spectral curves (fig. 62), which show the infrared transmittance from samples through a range of wavelengths, were measured at appropriate points to determine the amounts of organic compounds in each vitrain sample. Lower transmittance on the spectral curves indicates higher contents of specific organic-chemical groups. Because the amounts of benzene-ring compounds in the vitrains appeared to vary in some systematic manner, we investigated the amounts of these compounds further. The axial stress at failure, confining stress, and transmittance for the wavelength represented by 1,2-position isomers of benzene-ring compounds were then recalculated so that $172,400-\mathrm{kPa}$ $\left(25,000-\mathrm{lbf} / \mathrm{in}^{2}\right)$ axial stress, $69,000-\mathrm{kPa}\left(10,000-\mathrm{lbf} / \mathrm{in}^{2}\right)$ confining stress, and the transmittance at $13.29 \times 10^{4} \mathrm{~A}$ (angstroms) were unitized to 100 percent in a procedure similar to practices common in petrologic calculations (Alling, 1936, p. 25; Spock, 1962, p. 285-287). When plotted in ternary diagrams (fig. $63 A$ ), the distribution of the plotted points can be closely represented by a curved line, showing that the failure stresses partially depend upon the amounts of these benzene-ring compounds in the coal.

We also measured the infrared spectral curves for the contents of 1,2,4-position; 1,2,3,4-position; and 1, 4-position isomers of benzene rings (fig. $63 B$ ) and for aliphatic hydrocarbons (fig. $63 C$ ) in vitrain from the same cores from Sunnyside No. 3 Mine. The 1,2,3, 4-position or 1,4-position isomers of benzene rings (wavelength at maximum transmission $12.30 \times 10^{4} \mathrm{~A}$ ) yield results similar to those for the 1,2-position isomers of benzene rings, although the spread of the points representing higher stress levels is greater. The curves fitted by inspection to the plotted points in figures $63 A$ and $63 B$ are nearly identical. When plotted in a similar ternary diagram (fig. $63 C$ ), the results of measuring the contents of aliphatic hydrocarbons (wavelength $3.45 \times 10^{4} \mathrm{~A}$ ) showed much more dispersion than either of the types of benzene-ring substitutions and resulted in a random distribution. A few fusains were analyzed for comparison with the vitrain; as shown in figures $63 B$ and $63 C$, these results showed no systematic variation. Somewhat similar correlations between chemistry and strength of coals have been reported previously. Hobbs (1964) found that the yield stress of low-rank British coals decreased with increasing volatile content above $34,500-\mathrm{kPa}\left(5,000-\mathrm{lbf} / \mathrm{in}^{2}\right)$ confining stress. 


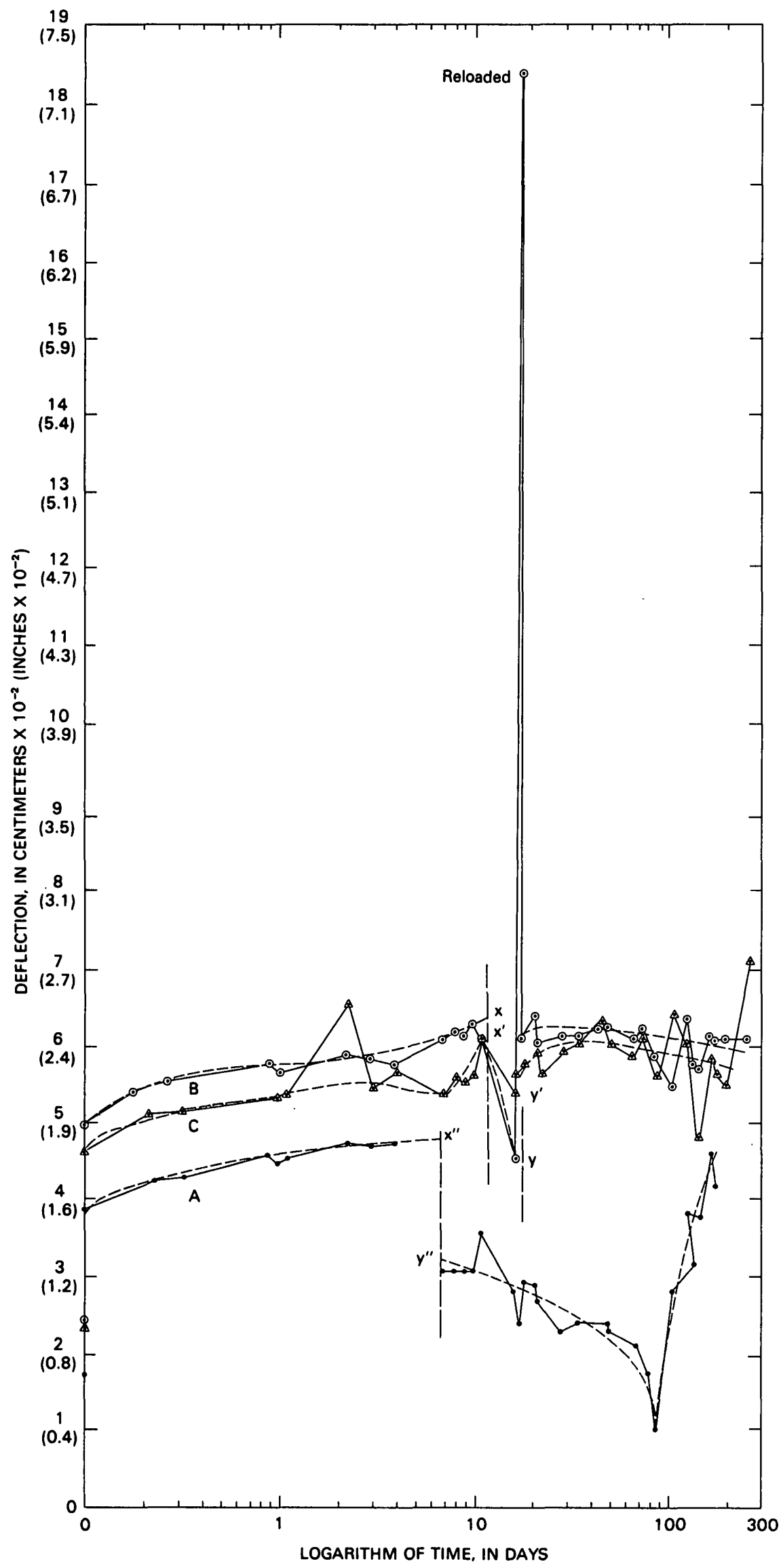

Figure 60.-Deflection of bars of coal from Sunnyside No. 1 Mine plotted against logarithm of time. Bar loaded with $85 \mathrm{~g}$ (3.0 oz), unloaded after 7 days (A, dots); bar loaded with $85 \mathrm{~g}$ ( $3.0 \mathrm{oz})$, unloaded during 10 th day, and reloaded $(B$, open circles about dots); and bar loaded with $125 \mathrm{~g}$ (4.4 oz), unloaded at 10.1 days, and reloaded at 10.8 days (C, open triangles about dots). Dashed curves are fitted mechanically using French curves, to show general trends of deflection. $x, x^{\prime}$, and $x^{\prime \prime}$ indicate points on curves at unloading and onset of deflection to points $y, y^{\prime}$, and $y^{\prime \prime}$. 


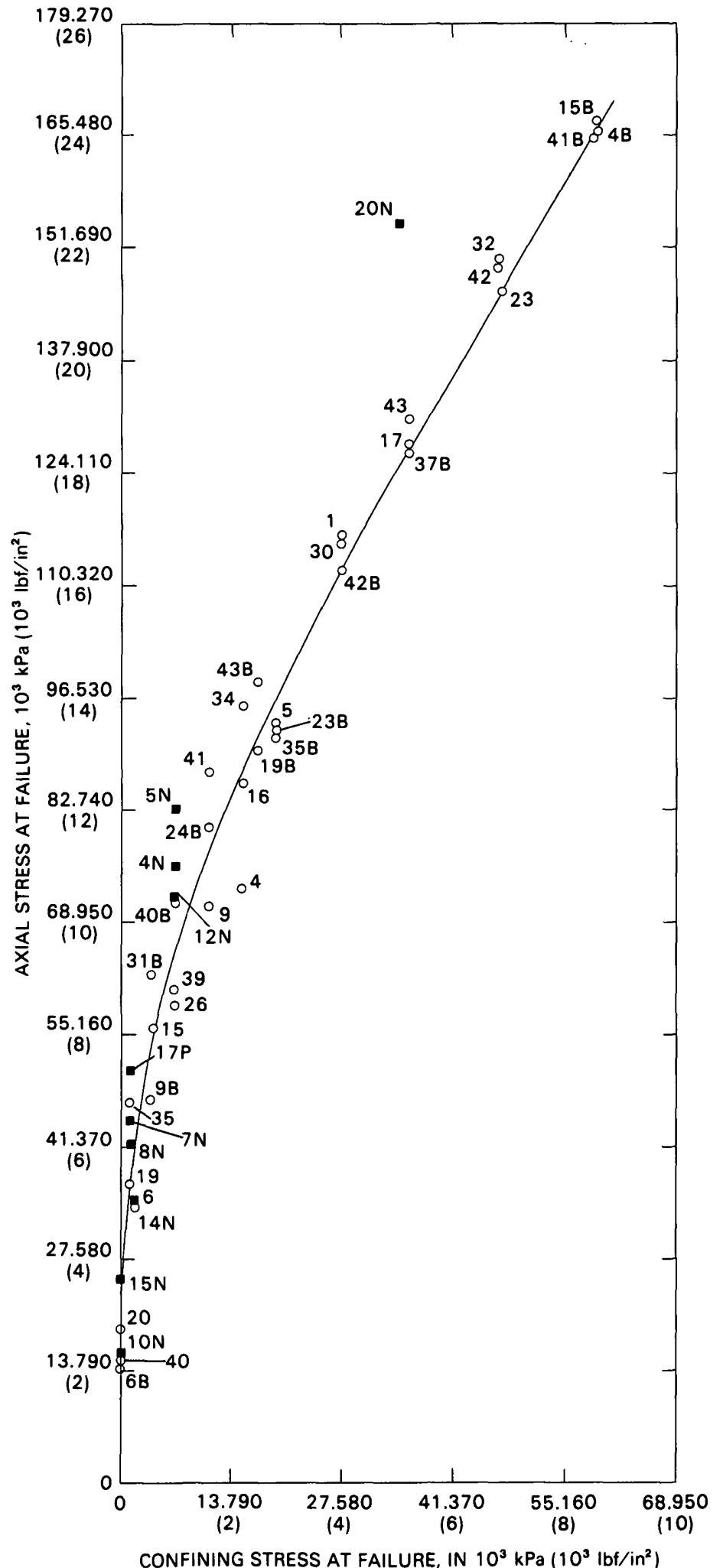

Figure 61.-Results of triaxial compressive testing of coal cores from Sunnyside No. 1 Mine (open circles) and Sunnyside No. 3 Mine (solid squares), showing small variations in strengths of cores tested at the same confining stresses. For comparison, numbers and letters correspond to those in figures 61-63. No. 3 Mine data from F.L. Gaddy, E.R. Rodriguez, and T.C. Miller (written commun., 1959). 
L. J. Fredrickson, Jr. (Spectran Laboratories, oral commun., 1960), who did the infrared spectral analyses, thought that kaolinite in the Sunnyside No. 3 Mine coal showed a consistent variation through the samples. The ternary diagram for kaolinite (fig. 64) shows little dispersion at low stress levels and approximates the curves for benzene rings, but at high stress levels it shows increasingly greater dispersion of the plotted points. Apparently, kaolinite content influences the strength of coal only at low confining stresses.

The infrared spectral analyses seem to indicate that some organic chemical constituents of coal, principally the benzene-ring compounds, are correlated with stresses in the coal at failure. Because the organic compounds formed during coalification, these compounds are indigenous to the coal. Most of the variations in amounts of the compounds, therefore, are original, but some of the variations may have resulted from molecular rearrangement during the compressive testing procedures. Kaolinite, in contrast, is a detrital component carried into the original coal swamp by rivers, and any correlation between kaolinite content and strength of the coal may indicate that kaolinite influences the mining stress levels at which the coal fails. Because curves for organic compounds (fig. 63) and kaolinite (fig. 64) are similar, the chemical composition of coal probably affects the strength of the coal more than the stress on the coal changes the chemical composition of the coal. These results suggest that, by using infrared spectral analyses of benzene-ring compounds and kaolinite in combination, the strengths of coals in new mining areas might be estimated as an aid to design of mining plans. Kaolinite content estimates, however, would only be useful at low levels of confining stress.

\section{CONCLUSIONS}

Although the mechanisms producing coal mine bumps and related types of failures in underground coal mines are complex, the results of the work in the Sunnyside coal mining district do permit several conclusions. These conclusions may not be generally applicable and might not even apply to mining in the entire Sunnyside district because of subtle differences in geology as well as differences in mining procedures. Some techniques of study and understanding of mechanisms of failure that have been identified can be used to establish geologic principles and to suggest mining practices that may minimize coal mine bumps in other coal mining areas:

1. Bumps are only one facet of mine-opening deformation that results from high stress concentration. If roofs and ribs are strongly supported, floors may heave, and the additional stress on floors may cause ribs to bump. Partially yieldable support, however, may relieve abnormal stress concentrations and reduce incidence of violent deformation.

2. Mine ribs commonly fail along curving shear fractures that increase in dip downward (figs. 19, 20, 22).

3. Many mine roofs and floors fail as results of strong components of lateral stress. Such failures may be followed at later times by violent bumps of ribs.

4. Deformational features in the coal are of both premine and post-mine ages.

5. Coal in the Sunnyside Mines is deformed by both fracture and creep.

6. Shatter zones in the mines have both direct and indirect relationships to bumps. Mine openings oriented at large angles with respect to shatter zones are more prone to violent bumps than are openings oriented at small angles to shatter zones.

7. Geologic features, such as lithologies of roof rocks, orientations of sand grains, ripple marks, and trace fossils, and stratigraphy of roofs and floors, strongly influence the deformation of mine openings, including bumps.

8. Subsidence of the land surface is a result of collapse of roof rocks into mined-out openings. The collapse extends upward through as much as $680 \mathrm{~m}(2,220 \mathrm{ft})$ of overburden which includes several thick, competent sandstones.

9. Stress accumulated as a result of mining tends to concentrate along faults and other geologic discontinuities.

10. Triaxial compressive tests of coal indicate that the compressive strength of coal increases markedly when subjected to lateral (confining) stress. Coal from the Sunnyside No. 1 Mine is slightly stronger than coal from the Sunnyside No. 3 Mine, which may account for the greater number of violent bumps in the No. 1 Mine.

11. The failure strengths of coal samples at low levels of confining stress are affected by small amounts of kaolinite contained in vitrain. The contents of benzene-ring compounds apparently can be correlated with failure strengths. 

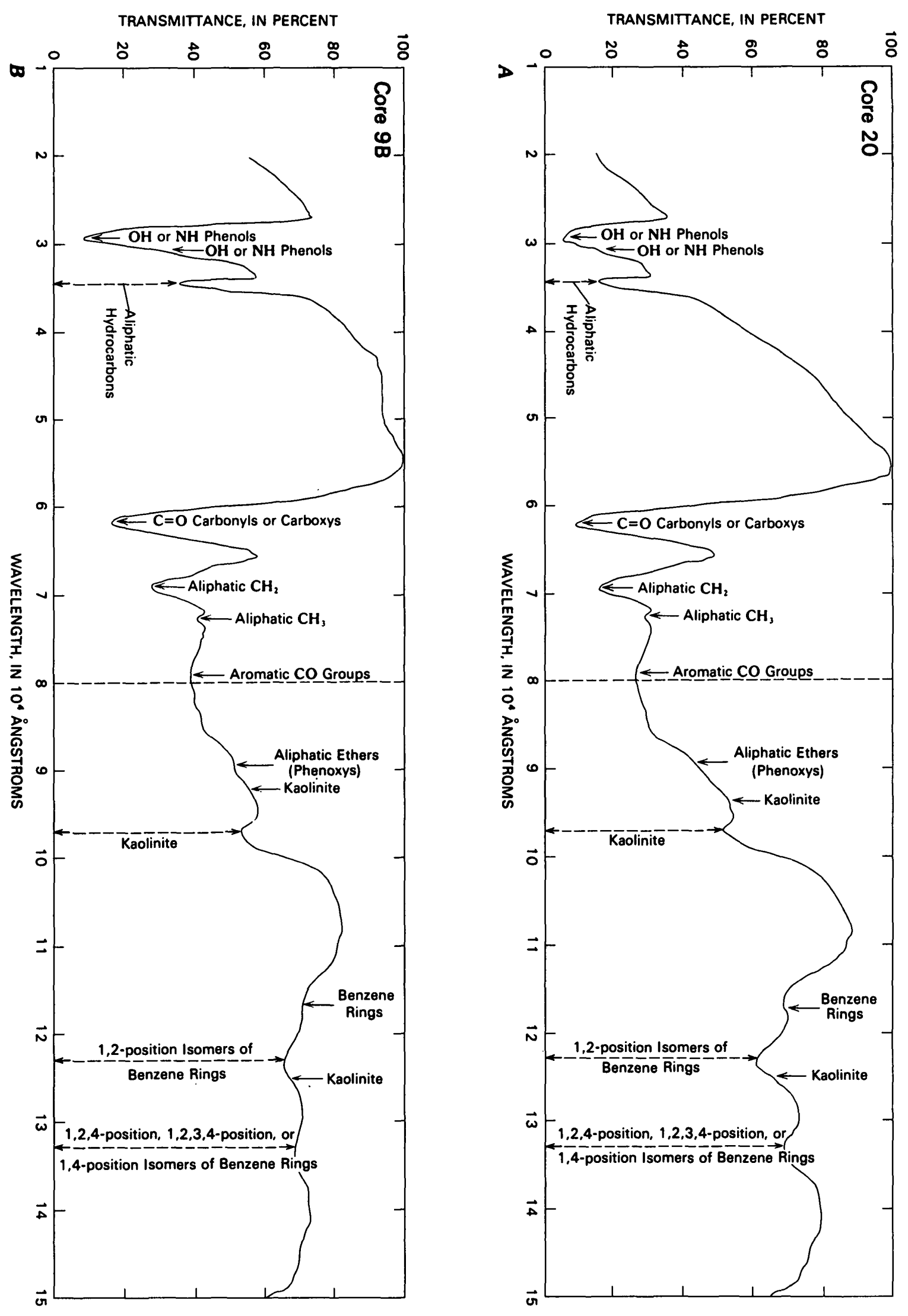

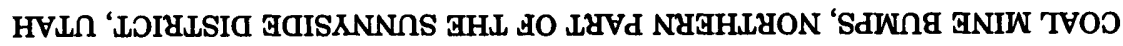




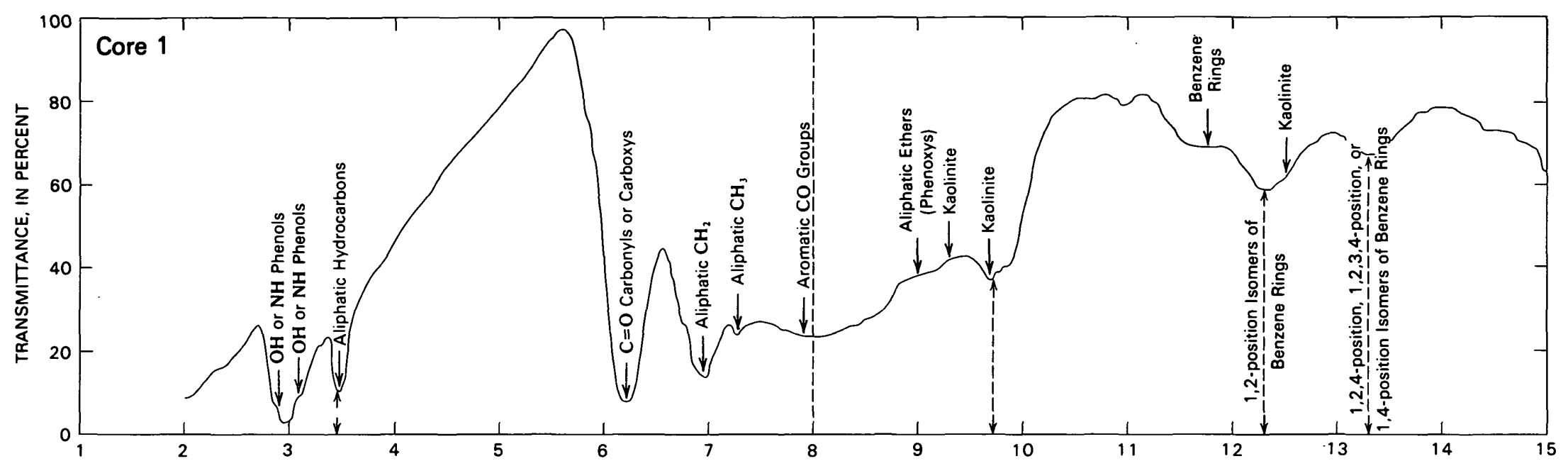

C

WAVELENGTH, IN $10^{4}$ ÅNGSTROMS

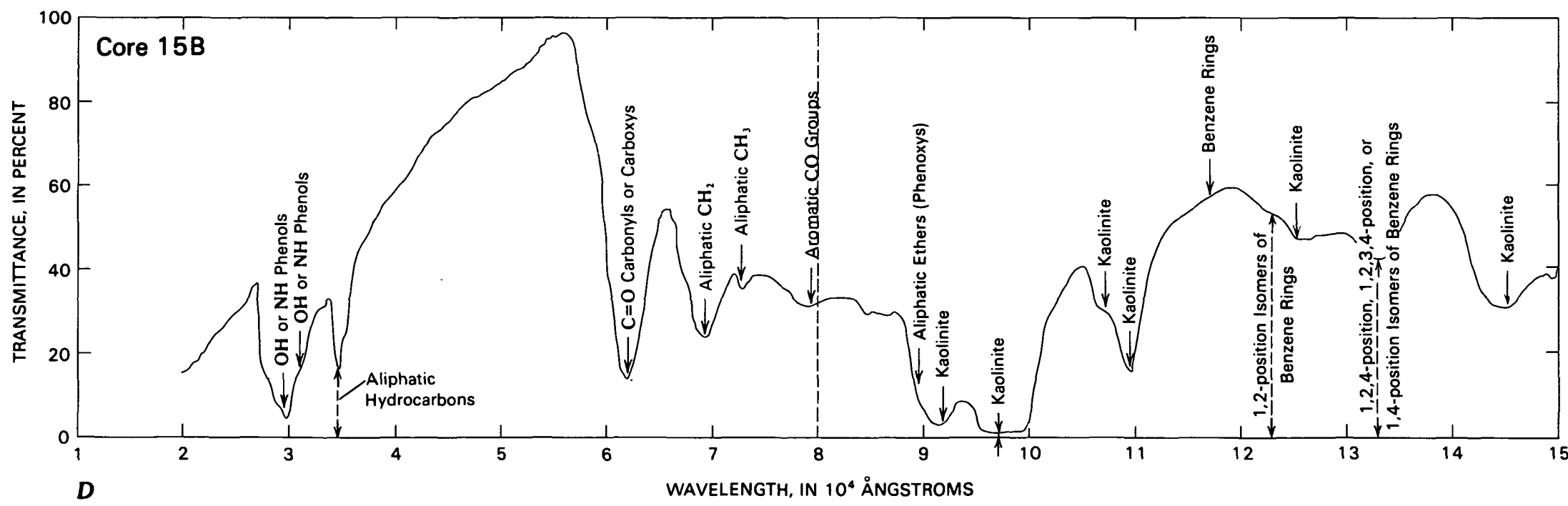

Figure 62.-Infrared spectra of vitrains from coal cores, Sunnyside No. 3 Mine, Utah (table 4; fig. 61). Points on the spectral curves representing selected groups of organic chemicals and of kaolinite are indicated by arrows; components measured and shown in figures $63 A, 63 B$, and $63 C$ indicated by dashed arrows below the curves. (L. D. Frederickson, Jr., of Spectran Laboratories, analyst.) A, Core 20 after testing at zero confining stress. $B$, Core $9 \mathrm{~B}$ after triaxial testing at 4,140-kPa (600-lbf/in ${ }^{2}$ ) confining stress. $C$, Core 1 after triaxial testing at $27,580-\mathrm{kPa}\left(4,000-\mathrm{lbf}_{1} \mathrm{in}^{2}\right)$ confining stress. $D$, Core $15 \mathrm{~B}$ after triaxial testing at $58,608-\mathrm{kPa}\left(8,500-\mathrm{lbf} / \mathrm{in}^{2}\right)$ confining stress. 


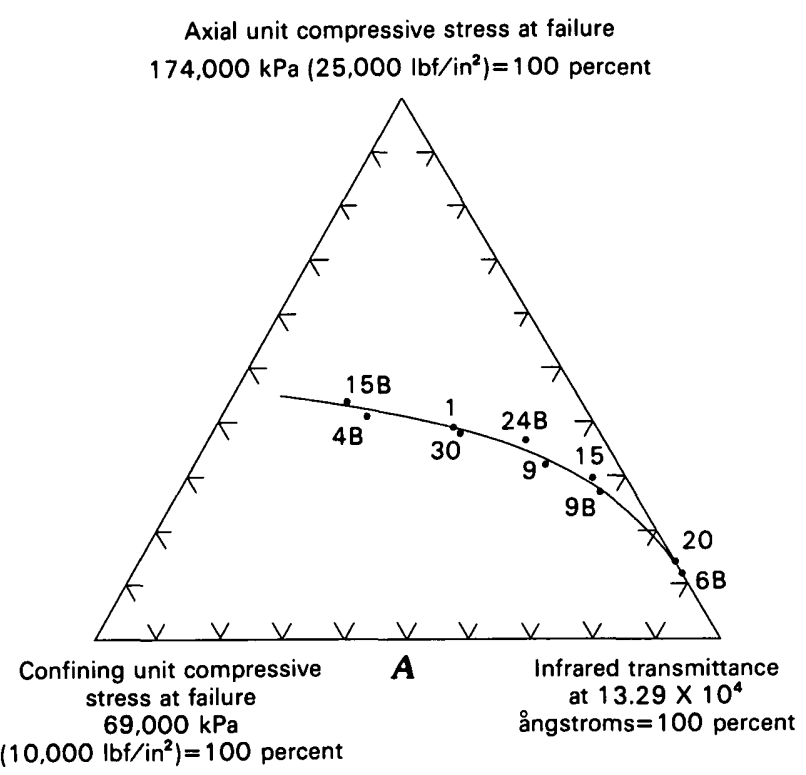

Axial unit compressive stress at failure $174,000 \mathrm{kPa}\left(25,000 \mathrm{lbf} / \mathrm{in}^{2}\right)=100$ percent

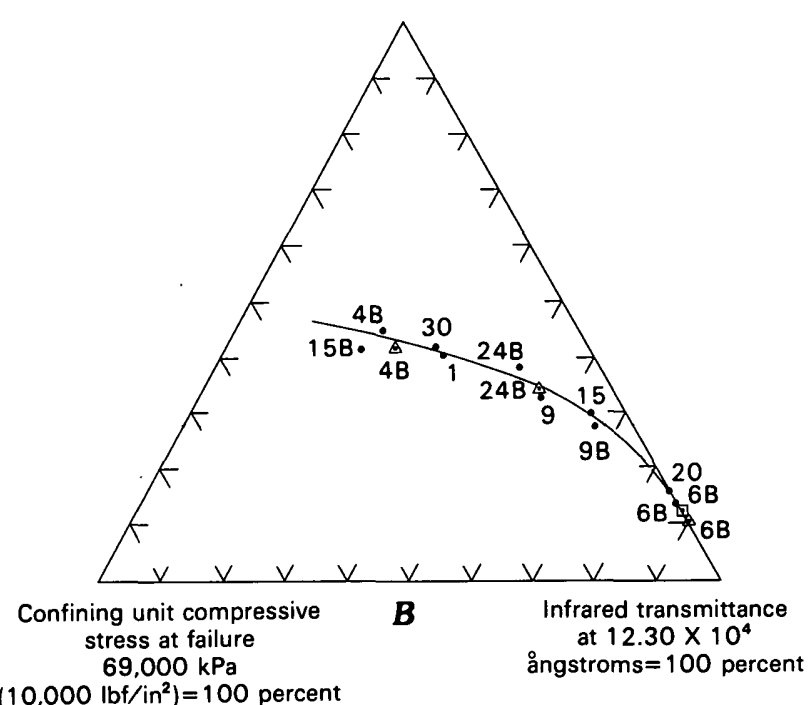

$\left(10,000 \mathrm{lbf} / \mathrm{in}^{2}\right)=100$ percent
Axial unit compressive stress at failure $174,000 \mathrm{kPa}\left(25,000 \mathrm{lbf} / \mathrm{in}^{2}\right)=100$ percent

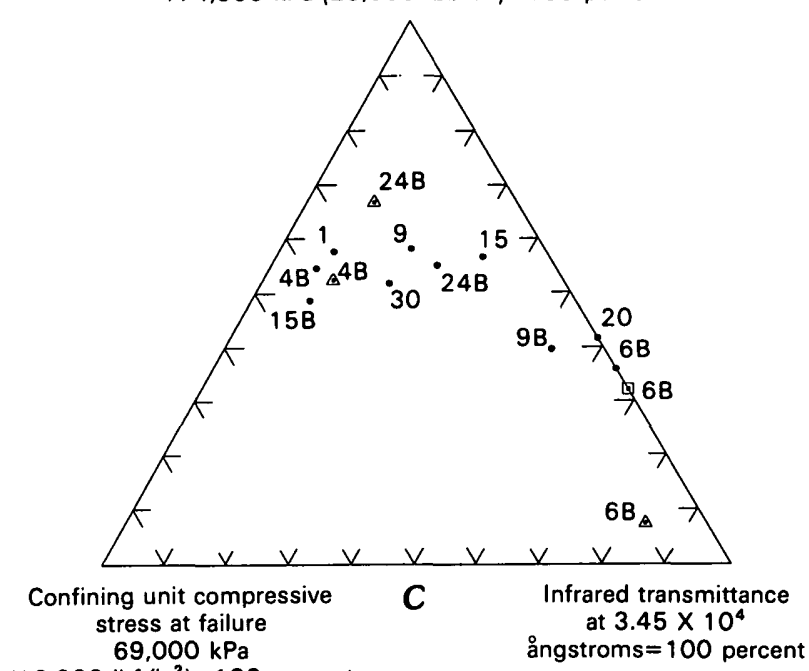

$\left(10,000 \mathrm{lbf} / \mathrm{in}^{2}\right)=100$ percent

FIGURE 63.-Ternary diagrams showing axial (longitudinal) compressive stress, confining stress, and infrared transmittance corresponding to the content of organic-chemical compounds in coal cores, Sunnyside No. 3 Mine, Utah. Dots are vitrain, open triangles about dots are fusain, and the open square about dot is a composite sample: $A, 1,2$-position isomers of benzene rings; $B, 1,2,4$-position, 1,2,3,4-position, or 1,4position isomers of benzene rings; and $C$, aliphatic hydrocarbons. Trend lines were drawn by inspection using a flexible curve through vitrain results only.

\section{REFERENCES}

Alling, H.L., 1936, Interpretive petrology of the igneous rocks: New York, McGraw-Hill Book Company, Inc., 353 p.

Avershin, S.G., 1955, Gorniye ydary: Moscow, U.S.S.R., Yglietekizdat, $223 \mathrm{p}$.

Bieniawski, Z.T., 1968, In situ strength and deformation characteristics of coal: International Journal of Engineering Geology, v. 2 , no. 5 , p. 325-340.

Billings, M.P., 1954, Structural geology (2d ed.): Englewood Cliffs, N.J., Prentice-Hall Inc., 514 p.
Bird, P.H., 1942, What are the causes of rock bursts?, in Bucky, P.B., ed., Rockbursts, a symposium: Mining Technology, v. 6, no. 2, p. 21-25.

Brauner, Gerhard, 1973, Subsidence due to underground mining, pt. 2 of Ground movements and mining damage: U.S. Bureau of Mines Information Circular 8572, $53 \mathrm{p}$.

Brodsky, Harold, 1960, Mesaverde Group at Sunnyside, Utah: U.S. Geological Survey open-file report, $70 \mathrm{p}$.

Budd, C.H., 1968, A microscopic examination of mechanically deformed anisotropic rocks: Austin, University of Texas M.S. thesis, $216 \mathrm{p}$.

Carne, J.E., 1903, The kerosene shale deposits of New South Wales: New South Wales Geological Survey Memoir 3, 333 p. 
Axial unit compressive stress at failure $174,000 \mathrm{kPa}\left(25,000 \mathrm{lbf} / \mathrm{in}^{2}\right)=100$ percent

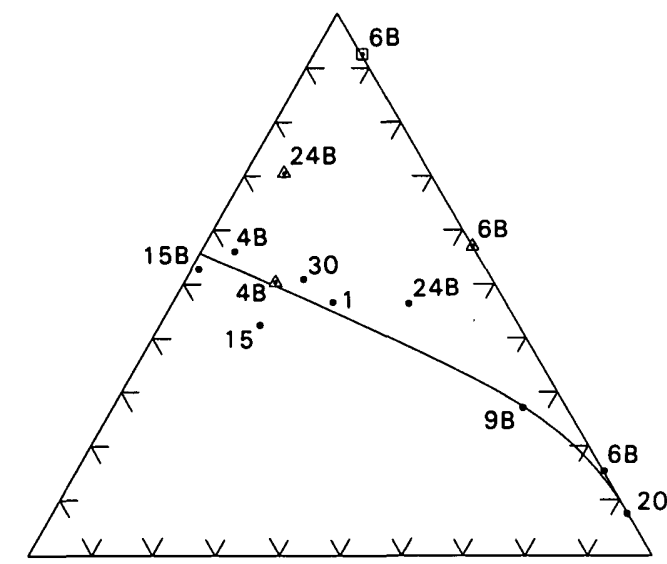

Confining unit compressive stress at failure $69000 \mathrm{kPa}$ $\left(10,000 \mathrm{lbf} / \mathrm{in}^{2}\right)=100$ percent at $9.67 \times 10^{4}$ ångstroms $=100$ percent

FIgure 64.-Ternary diagram showing axial (longitudinal) compressive stress, confining stress, and infrared transmittance corresponding to the kaolinite content in coal cores from Sunnyside No. 3 Mine, Utah. Dots are vitrain, triangles about dots are are fusain, and the box about dot is a composite sample. Trend line was drawn by inspection using a flexible curve through vitrain results only:

Slark, F.R., 1928, Economic geology of the Castlegate, Wellington, and Sunnyside quadrangles, Carbon County, Utah: U.S. Geological Survey Bulletin 793, 165 p.

Coates, D.F., 1970, Rock mechanic principles: Canadian Department of Energy, Mines and Resources, Mines Branch Monograph 874 (revised), $446 \mathrm{p}$.

Sorlett, A.V., and Emery, C.L., 1959, Prestress and stress redistribution in rocks around a mine opening: Canadian Mining and Metallurgical Bulletin 52, p. 372-384.

Jrouch, S.L., and Fairhurst, C., 1973, The mechanics of coal mine bumps and the interaction between coal pillars, mine roof, and floor: U.S. Bureau of Mines Open-File Report 53-73, 87 p. [Available from U.S. Department of Commerce National Technical Information Service, Springfield, Virginia 22161]

Dunrud, C.R., 1976, Some engineering geologic factors controlling coal mine subsidence in Utah and Colorado: U.S. Geological Survey Professional Paper 969, 39 p.

Junrud, C.R., and Barnes, B.K., 1972, Engineering geologic map of the Geneva mine area, Carbon and Emery Counties, Utah: U.S. Geological Survey Miscellaneous Geologic Investigations Map I-704, scale 1:6,000.

Ivans, W.H., 1941, The strength of undermined strata: Institution of Mining and Metallurgy Bulletin, No. 439, p. 1-26.

Tarmer, I.W., and Pooley, F.D., 1967, A hypothesis to explain the occurrence of outbursts in coal, based on a study of West Wales outburst coal: International Journal of Rock Mechanics and Mining Science, v. 4, no. 2, p. 189-193.

Friedel, R.A., and Queiser, J.A., 1956, Infrared analysis of bituminous coals and other carbonaceous materials: Analytical Chemistry, v. 28, no. 1., p. 22-30.

1966, Infrared and ultraviolet spectrometric techniques and spectra-structure correlations: U.S. Bureau of Mines Bulletin $632,32 \mathrm{p}$.

Gary, Margaret, McAfee, Robert, Jr., and Wolf, C.L., eds., 1972, Glossary of geology: Washington, D.C., American Geological Institute, $857 \mathrm{p}$.

Greenwald, H.P., Howarth, H.C., and Hartmann, Irving, 1939, Experiments on the strength of small pillars of coal in the Pittsburgh bed: U.S. Bureau of Mines Technical Paper 605, 22 p.

Griggs, David, 1939, Creep of rocks: Journal of Geology, v. 47, no. 3, p. 225-251.

Grond, G.J.A., 1951, Precise topographical measurements in coal mine underground works: International Conference on Rock Pressure and Support in the Workings, 1st, Liege, Belgium, Institut National de l'Industrie Charbonierre, p. 52-66.

Harrison, J.E., and Wells, J.D., 1956, Geology and ore deposits of the Freeland-Lamartine district, Clear Creek County, Colorado: U.S. Geological Survey Bulletin 1032-B, 127 p.

Hobbs, D.W., 1964, Strength and stress-strain characteristics of coal in triaxial compression: Journal of Geology, v. 72, no. 2, p. 214-231.

Holland, C.T., and Thomas, Edward, 1954, Coal-mine bumps-some aspects of occurrence, cause, and control: U.S. Bureau of Mines Bulletin 535, $37 \mathrm{p}$.

Hunt, C.B., 1956, Cenozoic geology of the Colorado Plateau: U.S. Geological Survey Professional Paper 279, 98 p.

Ingles, O.G., Lee, I.K., and Neil, R.C., 1973, The influence of stress history on lateral strain: Journal of the International Society for Rock Mechanics, v. 5, no. 4, p. 203-213.

Isaacson, E. De St. Q., 1958, Rock pressure in mines: London, Mining Publications, $212 \mathrm{p}$.

Jeremic, M.L., 1980, Influence of shear deformation structures in coal on selecting methods of mining: Rock Mechanics, v. 13, no. 1., p. 23-38.

1981, Strength properties of coal bearing strata of the Plains Region, Western Canada: Rudarsko-Metalurski Zbornik, v. 28, no. 1 , p. $63-76$.

Kanizay, S.P., 1962, Mohr's theory of strength and Prandtl's compressed cell in relation to vertical tectonics: U.S. Geological Survey Professional Paper 414-B, 16 p.

Maberry, J.O., 1968, Relation of sedimentary structures to coal mine bumps: Geological Society of America Abstracts with Programs, p. 182.

1971, Sedimentary features of the Blackhawk Formation (Cretaceous) in the Sunnyside district, Carbon County, Utah: U.S. Geological Survey Professional Paper 688, 44 p.

McKee, E.D., and Weir, G.W., 1953, Terminology for stratification and cross-stratification in sedimentary rock: Geological Society of America Bulletin, v. 64, no. 4, p. 381-390.

McKinstry, H.E., 1948, Mining geology: New York, Prentice-Hall, Inc., $680 \mathrm{p}$.

Morrison, R.G.K., 1947, A general theory of rock bursts: Engineering and Mining Journal, v. 148 , no. 12 , p. 70-72.

Nadai, Arpad, 1950, Theory of flow and fracture of solids: New York, McGraw-Hill Book Co., 572 p.

Osterwald, F.W., 1961, Deformation and stress distribution around coal mine workings in Sunnyside No. 1 Mine, Utah: U.S. Geological Survey Professional Paper 424-C, p. C349-C353.

1962a, Preliminary lithologic and structural map of Sunnyside No. 1 Mine area, Carbon County, Utah, Sheet 1, Showing coal outcrops; Sheet 2 , showing coal mine workings, mined-out areas, overburden thickness contours, subsidence cracks: U.S. Geological Survey Coal Investigations Map C-50, scale 1:6,000.

$1962 \mathrm{~b}$, USGS relates geologic structures to bumps and deformation in coal mine workings: Mining Engineering, v. 14, no. 4 , p. $63-68$. 
Osterwald, F.W., Bennetti, J.B., Jr., Dunrud, C.R., and Maberry, J.O., 1971, Field instrumentation studies of earth tremors and their geologic environments in central Utah coal mining areas: U.S. Geological Survey Professional Paper 693, 20 p.

Osterwald, F.W., and Brodsky, Harold, 1960, Tentative correlation between coal mine bumps and orientation of mine workings in the Sunnyside No. 1 Mine, Utah: U.S. Geological Survey Professional Paper 400-B, p. B144-B146.

Osterwald, F.W., and Dunrud, C.R., 1965, Geology applied to the study of coal mine bumps at Sunnyside, Utah: Society of Mining Engineers Transactions, v. 232, no. 2, p. 168-174.

1966, Instrumentation study of coal mine bumps, Sunnyside district, Utah: Utah Geological and Mineralogical Survey Bulletin 80, p. 97-110.

Osterwald, F.W., Dunrud, C.R., and Maberry, J.O., 1969, Preliminary geologic map of the Columbia area, Carbon and Emery Counties, Utah: U.S. Geological Survey Miscellaneous Geologic Investigations Map I-582, scale 1:6,000.

Osterwald, F.W., and Maberry, J.O., 1974, Engineering geologic map of the Woodside quadrangle, Emery and Carbon Counties, Utah: U.S. Geological Survey Miscellaneous Investigations Map I-798, scale $1: 48,000$.

Osterwald, F.W., Maberry, J.O., and Dunrud, C.R., 1981, Bedrock, surficial, and economic geology of the Sunnyside coal mining district, Utah: U.S. Geological Survey Professional Paper 1166, $68 \mathrm{p}$.

Peperakis, John, 1958, Mountain bumps at the Sunnyside mines: Mining Engineering, v. 10, no. 9, p. 982-986.

Prandtl, Ludwig, 1924, Spannungsverteilung in plastichen Köpern International Congress on Applied Mechanics, 1st, Delft, Proceedings, p. 41-54.

Rischmüller, Hanserner, 1955, Kleintektonik in der Kohle. Schlecton, Augen- und Pyramiden Kohle unter besonderor Berüeksichtigung der tektonischen Verhältnisse in Wattenscheider Sattel: Glückauf v. 91, nos. 33-34, p. 929-938.

Scheibner, B.J., 1979, Geology of the single-entry project at Sunnyside Coal Mines 1 and 2, Sunnyside, Utah: U.S. Bureau of Mines Report of Investigations RI-8402, 106 p.
Serata, Shosei, and Gloyna, E.F., 1960, Principles of structural stability of underground salt cavities: Journal of Geophysical Research, v, 65, no. 9, p. 2979-2987.

Singer, F.L., 1951, Strength of materials: New York, Harper and Brothers, Publishers, $469 \mathrm{p}$.

Spackeler, George, 1958, Observations on the distribution of stress around coal and salt workings: Berlin, Akademie der Wissenschaften, Section für Bergbau [International Strata Control Congress, 1958, Leipzig, English translation], p. 305-319.

Spock, L.E., 1962, Guide to the study of rocks, 2d ed.: New York, Harper and Brothers, Publishers, 298 p.

Stokes, W.L., and Varnes, D.J., 1955, Glossary of selected geologic terms: Colorado Scientific Society Proceedings, v. 16, 165 p.

Stutzer, Otto, 1940, Geology of coal [translated and revised by Adolph C. Noe]: University of Chicago Press, $461 \mathrm{p}$.

Thrush, P.W., compiler and editor, and staff of the U.S. Bureau of Mines, 1968, A dictionary of mining, mineral, and related terms: Washington, D.C., U.S. Bureau of Mines, 1269 p.

U.S. Bureau of Reclamation, 1949, Shearing strength of concrete under high triaxial stress-computation of Mohr's envelope as a curve: Structural Research Laboratory Report SP-23, 28 p.

1953, Physical properties of some typical foundation rocks: Concrete Laboratory Report SP-39, 78 p.

U.S. Geological Survey, 1963, Geological Survey research 1963: U.S. Geological Survey Professional Paper 475-A, 300 p.

Vandale, A.E., 1967, Subsidence-a real or imaginary problem?: Mining Engineering, v. 19, no. 9, p. 86-88.

Varnes, D.J., 1962, Analysis of plastic deformation according to Von Mises' theory with application to the south Silverton area, San Juan County, Colorado: U.S. Geological Survey Professional Paper 378-B, 49 p.

Watts, A.C., 1918, An unusual "bounce" condition: Coal Age, v. 14, no. 23 , p. $1028-1030$.

Woodruff, S.D., 1966, Theory and application of rock mechanics to roof control and support problems v. 1 of, Methods of working coal and metal mines: New York, Pergamon Press, $364 \mathrm{p}$.

Youash, Y.Y., 1965a, Experimental deformation of layered rocks: College Station, Texas University Ph. D. thesis, $195 \mathrm{p}$.

$1965 \mathrm{~b}$, Experimental study of rock anisotropy [abs.]: Geological Society of America Special Paper 82, p. 314-315.

Manuscript published in the Central Region, Denver, Colo.

Edited by Thomas Kohnen

Color design by Larry J. Preisendorf

Graphic design by Larry J. Preisendorf

Cartography by Bill Ary

Type Composed by Marie F. Melone 